\title{
SITE SUPPORT PROGRAMECEIVED PLAN INFRASTRUCTURE OSTI PROGRAM
}

Prepared for the U.S. Department of Energy

Assistant Secretary for Environmental Management

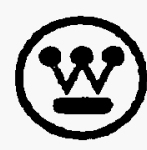

Westinghouse

Hanford Company Richland, Washington

Management and Operations Contractor for the

U.S. Department of Energy under Contract DE-AC06-87RL10930

Approved for public release; distribution is unlimited

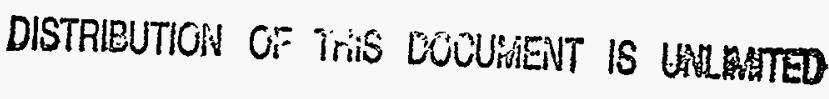



P.O. Box 1970 Richland, WA 99352

September 26, 1995

9503327B R3

Mr. W. A. Rutherford, Director

Site Infrastructure Division

U.S. Department of Energy

Richland Operations Office

Richland, Washington 99352

Dear Mr. Rutherford:

TRANSMITTAL OF FISCAL YEAR 1996 SITE SUPPORT PROGRAM PLAN FOR THE INFRASTRUCTURE PROGRAM

References: (1) Letter, N. M. Highland, RL, to President, WHC, "FY 1996

Program Pian Guidance," 9503012, dated June 13, 1995.

(2) Letter, G. A. Harvey, ICF KH, to S. R. Morgan, WHC, "Program Plans for ICF KH Utilities, General Purpose Facilities, Real Estate and Leasing, Site Planning, Energy Management, and Transportation," 9503327B, dated JuTy 20, 1995.

The Final FY 1996 Site Support Program Plan for the Infrastructure Program is attached for U.S. Department of Energy, Richland Operations Office approval.

If you have any questions, please contact Mr. A. D. Gadeken, of my staff, on 376-0495.

Very truity yours,

li: ising

G.'A.' Harvey, Manáger

Infrastructure Programs

sls

Attachment

$\begin{array}{ll}\text { RL - } & \text { J. J. Broderick } \\ \text { K. R. Ensign } \\ \text { M. J. Elsen } \\ \text { S. Herres } \\ \text { K. Kuon } \\ \text { L. L. Piper } \\ \text { T. O. Schmeeckle } \\ \text { R. W. Small } \\ \text { A. H. Wirkkala (w/o att.) }\end{array}$

Ecology - J. L. Hensley

S. J. Skurla 



\section{Site Support Program Plan \\ Fiscal Year 1996 \\ WBS 6.8}

\section{SSPP Approval Sheet}
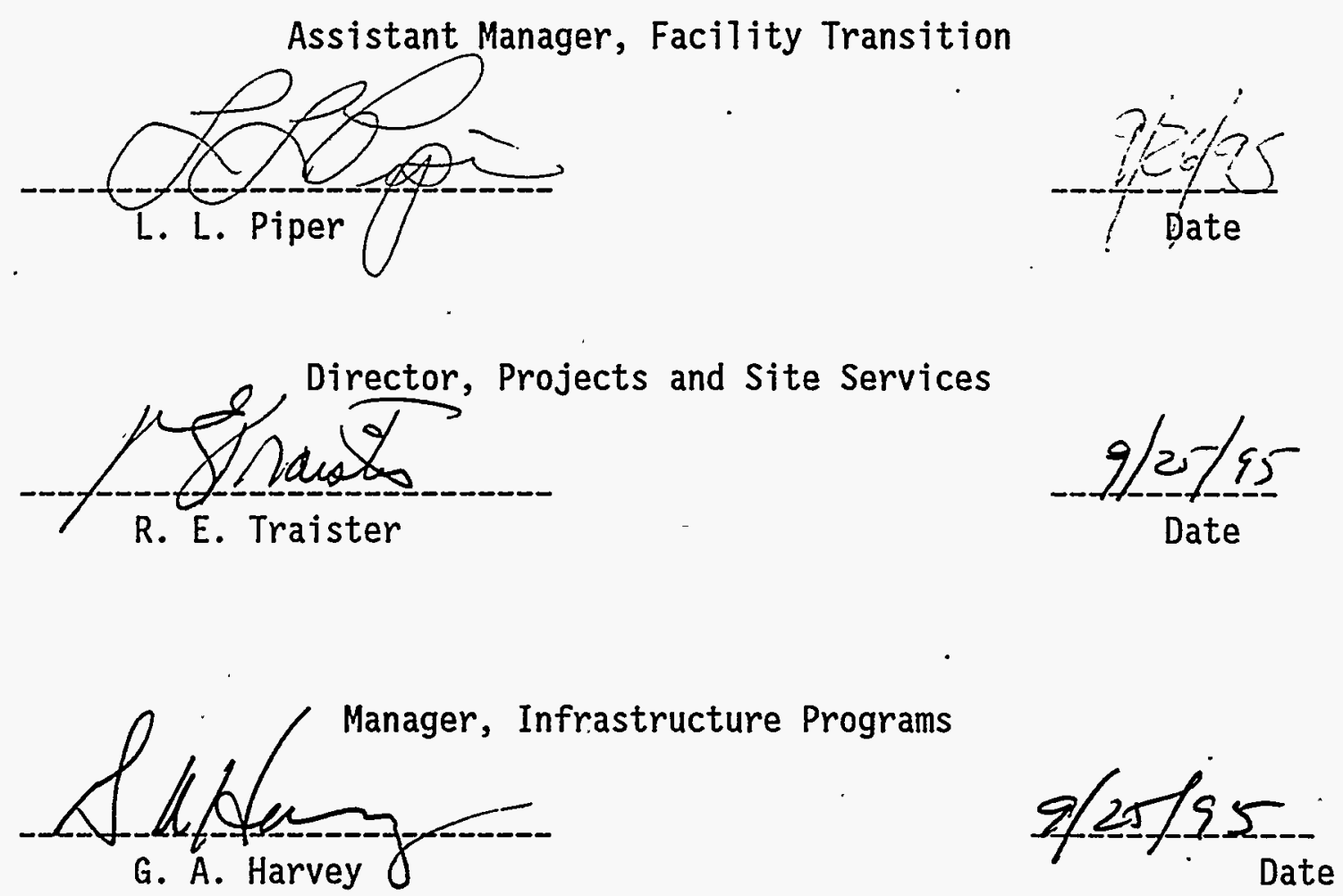



\section{INSERT FOR HBS 6.8 FY 1996 SSPP}

FY 1996 SSPP for WBS 6.8, Site Infrastructure is approved with the following exceptions and conditions.

WBS 6.8 - OVERALL the ratio of Exempt employees to Non-exempt and Bargaining Unit employees appears to be very high (-1 to 2$)$. The issue is whether or not the products. and services provided by the Exempt staff are essential to meeting DOE's requirements for each service area.

The Contractor is requested to provide to DOE, by October 13, 1995, a breakout, by individual, of reports prepared by each individual and their frequency, outputs or other services provided by each individual, DOE, WHC and Kaiser drivers for these reports and services and processes managed by each individual.

The Contractor is also requested to identify what individual outputs would be el iminated if within WBS 6.8, the OVERALL ratio of Exempt to Non-Exempt plus Bargaining Unit Staff was 1 to 5 as opposed to the present ratio of 1 to 2 .

There is a potential annual savings in the future of between 15 and 25 million dollars per year in addressing this concern. This is a very serious issue which must be resolved early in FY 1996 in order to realize the benefits. It should be noted that the contractor has been asked to justify staffing levels repeatedly over the last 18 months so it is our belief that October 13, 1995 is a realistic date for a response.
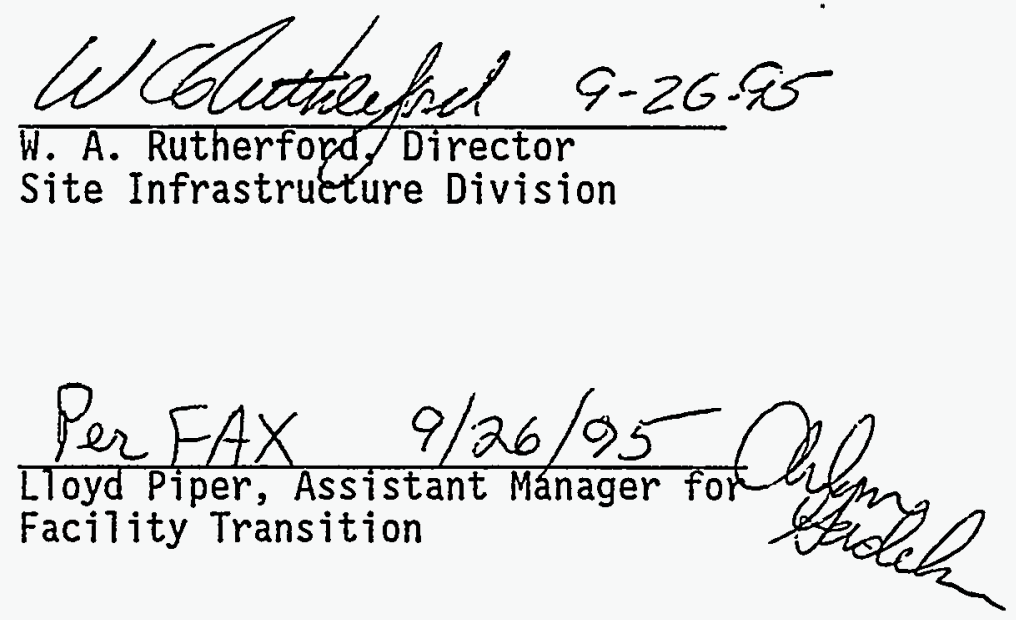



\section{RELEASE AUTHORIZATION}

Document Number: WHC-EP-1169, Rev. 0

Document Title: Site Support Program Plan Infrastructure Program

Release Date: $\quad 09 / 15 / 95$

This document was reviewed following the procedures described in WHC-CM-3-4 and is:

APPROVED FOR PUBLIC RELEASE

WHC Information Release Administration Specialist:

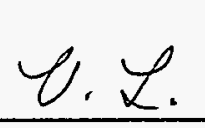

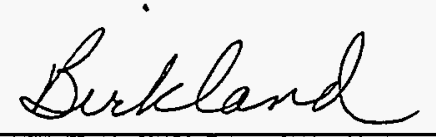

V. L. Birkland

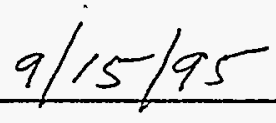





\title{
SITE SUPPORT PROGRAM PLAN INFRASTRUCTURE PROGRAM
}

\author{
R. E. Tiller \\ ICF Kaiser Hanford Company \\ Date Published \\ September 1995
}

Prepared for the U.S. Department of Energy

Assistant Secretary for Environmental Management

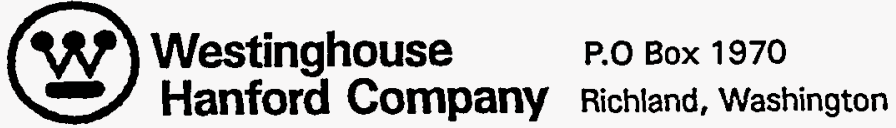

Management and Operations Contractor for the

U.S. Department of Energy under Contract DE-AC06-87RL10930

Approved for public release; distribution is unlimited 
LEGAL DISCLAIMER

This report was prepared as an account of work sponsored by an agency of the United States Government. Neither the United States Government nor any agency thereof, nor any of their employees, nor any of their contractors, subcontractors or their employees, makes any warranty, express or implied, or assumes any legal liability or responsibility for the accuracy, completeness, or any third party's use or the results of such use of any information, apparatus, product, or process disclosed, or represents that its use would not infringe privately owned rights. Reference herein to any specific commercial product, process, or service by trade name, trademark, manufacturer, or otherwise, does not necessarily constitute or imply its endorsement, recommendation, or favoring by the United States Government or any agency thereof or its contractors or subcontractors. The views and opinions of authors expressed herein do not necessarily state or reflect those of the United States Government or any agency thereof.

This report has been reproduced from the best available copy. Available in paper copy and microfiche.

Available to the U.S. Department of Energy

and its contractors from

U.S. Department of Energy

Office of Scientific and Technical Information (OSTI)

P.O. Box 62

Oak Ridge, TN 37831

(615) 576-8401

Printed in the United States of America

DISCLM-3.CHP (1-91) 
CONTENTS

1.0 INFRASTRUCTURE PROGRAM OVERVIEW [WBS 6.8] $\ldots \ldots \ldots \ldots \ldots$ 1-1

1.1 PROGRAM MISSION $\ldots \ldots \ldots \ldots \ldots \ldots \ldots \ldots \ldots \ldots \ldots \ldots$

1.2 PROGRAM VISION $\ldots \ldots \ldots \ldots \ldots \ldots \ldots \ldots \ldots \ldots \ldots \ldots \ldots$

2.0 TECHNICAL REQUIREMENTS BASELINE . . . . . . . . . . . . . 2-1

2.1 PROGRAM WORK BREAKDOWN STRUCTURE . . . . . . . . . . . 2-1

2.1 .1 Utilities [WBS 6.8 .1$] \ldots \ldots \ldots \ldots \ldots \ldots \ldots \ldots . . \ldots \ldots .2$

2.1.2 Transportation [WBS 6.8.2] ................ 2-3

2.1.3 General Purpose Facilities [WBS 6.8.3] . . . . . . . . 2-4

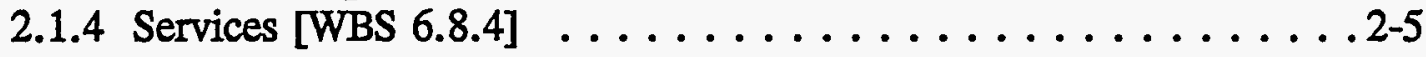

2.1.5 Energy Management $[$ WBS 6.8 .5$] \ldots \ldots \ldots \ldots \ldots \ldots \ldots . \ldots \ldots$

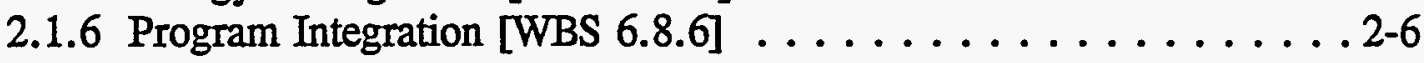

2.2 COST AND STAFFING DATA $\ldots \ldots \ldots \ldots \ldots \ldots \ldots \ldots \ldots . \ldots \ldots$

2.3 WORK BREAKDOWN STRUCTURE DICTIONARY . . . . . . . . . 2-8

2.4 WORK BREAKDOWN STRUCTURE AND RESPONSIBILITY

ASSIGNMENT MATRIX . . . . . . . . . . . . . 2-15

2.5 INFRASTRUCTURE PROGRAM ASSUMPTIONS AND

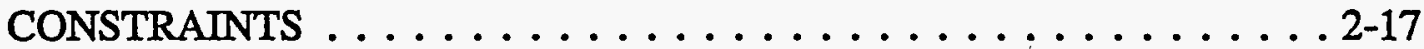

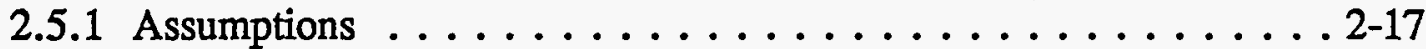

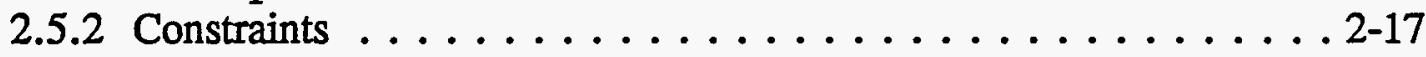

3.0 SCHEDULE BASELINE $\ldots \ldots \ldots \ldots \ldots \ldots \ldots \ldots \ldots \ldots \ldots \ldots \ldots \ldots \ldots \ldots$

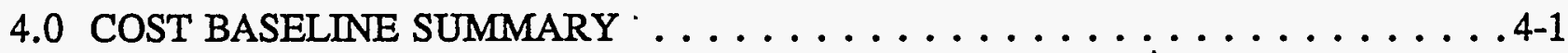

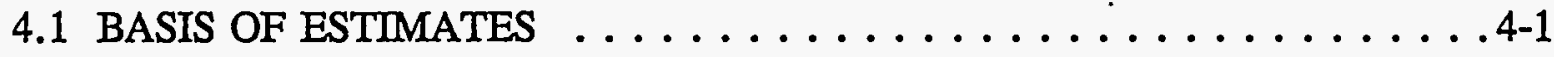

4.2 MANAGEMENT CONTROL . . . . . . . . . . . . . 4-1

4.3 CHANGE CONTROL . . . . . . . . . . . . . . . . . . 4-1

4.4 SUPPORTING INFORMATION $\ldots \ldots \ldots \ldots \ldots \ldots \ldots \ldots . \ldots . . \ldots .2$

5.0 PERFORMANCE MEASURES $\ldots \ldots \ldots \ldots \ldots \ldots \ldots \ldots \ldots \ldots \ldots \ldots \ldots$

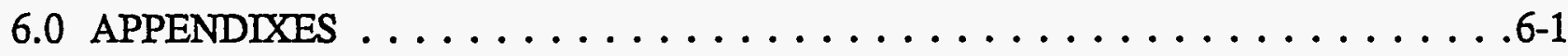

6.1 APPENDIX A - WBS 6.8 .1 [UTILITIES] . . . . . . . . . . 6-1

6.2 APPENDIX B - WBS 6.8 .2 [TRANSPORTATION] $\ldots \ldots \ldots \ldots . \ldots 6-1$

6.3 APPENDIX C - WBS 6.8.3 [GENERAL PURPOSE FACILITIES] . . . . 6 6-1

6.4 APPENDIX D - WBS 6.8 .4 [SERVICES] . . . . . . . . . . . 6-1

6.5 APPENDIX E - WBS 6.8 .5 [ENERGY MANAGEMENT] $\ldots \ldots \ldots \ldots 6-1$

6.6 APPENDIX F - WBS 6.8 .6 [PROGRAM INTEGRATION] $\ldots \ldots \ldots .6-1$ 



\section{LIST OF TABLES}

2-1 Staffing and Cost Baseline Summary $\ldots \ldots \ldots \ldots \ldots \ldots . \ldots . \ldots . . \ldots$ 2-7

2-2 WBS Dictionary Part I Summary [WBS 6.8 .1 Utilities] $\ldots \ldots \ldots$. . . . . . 2-8

2-3 WBS Dictionary Part I Summary [WBS 6.8 .2 Transportation] $\ldots \ldots \ldots . . . . .2-9$

2-4 WBS Dictionary Part I Summary [WBS 6.8 .3 General Purpose] . . . . . . . . . 2-10

2-5 WBS Dictionary Part I Summary [WBS 6.8 .4 Services] $\ldots \ldots \ldots$. . . . . . 2-11

2-6 WBS Dictionary Part I Summary [WBS 6.8.5 Energy Management] $\ldots \ldots \ldots$. . 2-12

2-7 WBS Dictionary Part I Summary [WBS 6.8.6 Program Integration] $\ldots \ldots \ldots$. . . 2-13

2-8 WBS·Dictionary Part I Summary [WBS 6.8.6 Department Overhead Summary] . . 2-14

3-1 Schedule Baseline (WBS 6.8) $\ldots \ldots \ldots \ldots \ldots \ldots \ldots \ldots \ldots . \ldots \ldots$. . . . . . . 



\subsection{Infra Programs Overview}





\subsection{INFRASTRUCTURE PROGRAM OVERVIEW [WBS 6.8]}

The Fiscal Year 1996 Infrastructure Program Site Support Program Plan addresses the mission objectives, workscope, work breakdown structures (WBS), management approach, and resource requirements for the Infrastructure Program. Attached to the plan are appendices that provide more detailed information associated with scope definition.

The Hanford Site's infrastructure has served the Site for nearly 50 years during defense materials production. Now with the challenges of the new environmental cleanup mission, Hanford's infrastructure must meet current and future mission needs in a constrained budget environment, while complying with more stringent environmental, safety, and health regulations. The infrastructure requires upgrading, streamlining, and enhancement in order to successfully support the site mission of cleaning up the Site, research and development, and economic transition.

\subsection{PROGRAM MISSION.}

The mission of the Infrastructure Program is to preserve, upgrade, maintain, operate, and forecast cost effective infrastructure support programs to facilitate the Hanford Site cleanup mission. Specific functions and services provided by the Infrastructure Program include utilities, transportation, general purpose facilities, services, and energy management. All Infrastructure Program activities will be performed in an environmentally sound, safe, economical, prudent, and reliable manner.

Hanford Site Infrastructure Program will be competitive with commercially provided services to offer the best price, quality, and service available.

\subsection{PROGRAM VISION}

Infrastructure will become a highly effective business unit by continually emphasizing the following practices into Infrastructure Program operations and actions:

- Have a safe work place that continually exceeds standards.

- Facilities and operations that meet or exceed environmental standards.

- Have clearly identified costs for products and services and a continual process to improve value.

- Site mission requirements are continually enhanced by products and services provided through the infrastructure. 
The program vision is a direct result of the Hanford Strategic Plan (DOE/RL-93-102) and the strategic goals within the plan. In particular, goal \#3 states "we will provide a safe infrastructure (e.g., utilities, transportation, general purpose facilities, or Sitewide services) in a cost effective way that supports accomplishment of the Hanford mission and meets or exceeds appropriate standards." The vision and strategic goals provide the basis for this program plan.

Strategies for attaining the Hanford Strategic Plan goal \#3 are:

- Identify and understand infrastructure requirements including core capabilities to be retained.

- Determine the best alternative (competitive with the best commercial services) for continuing to provide the required infrastructure.

- Implement the best alternative considering capability, capacity, safety, and reliability.

- Bring together management, employees, organized labor, and the community to find continuing employment for affected workers as the Site infrastructure transitions.

Success indicators for the goal and strategies are:

- Improvement toward benchmark operating costs.

- The number of OSHA incidents reportable where infrastructure is a contributing cause.

- The number of missed or changed Hanford milestones where infrastructure is the cause. 
2.0 Technical Requirements Baseline 



\subsection{TECHNICAL REQUIREMENTS BASELINE}

\subsection{PROGRAM WORK BREAKDOWN STRUCTURE} chart.

The Infrastructure Program work breakdown structure is represented by the following

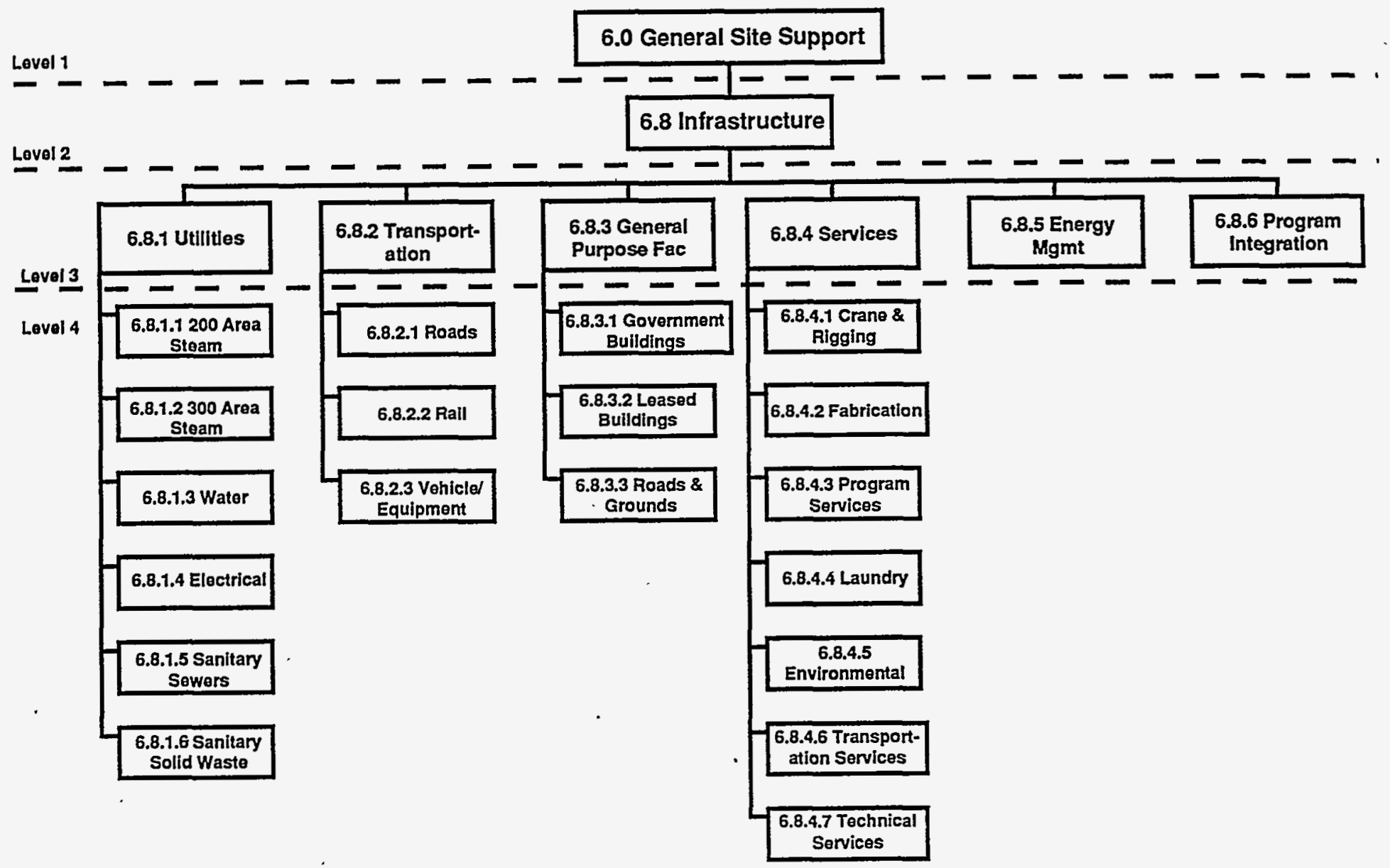




\subsubsection{Utilities [WBS 6.8.1]}

Utilities provides for the delivery of steam, water, electricity, collection and disposal of sanitary sewage, and solid waste. It generally requires the operation and maintenance of facilities, systems, equipment, and the furnishing of labor. Utilities may be provided by contracting with agencies that furnish facilities, systems and/or equipment.

Steam production currently involves operation of three facilities, the 200W Area, 200E Area and 300 Area power plants.

Total steam production capacity in the 200 Areas is $375,000 \mathrm{Lbs} / \mathrm{hr}$ and the $200 \mathrm{~W}$ and $200 \mathrm{E}$ areas are interconnected. Production capability based on availability of equipment, personnel and resources for FY 1996 is $235,000 \mathrm{lbs} / \mathrm{hr}$ which will match anticipated winter peak demand. The 200 East facility also provides for backup electrical generation which serves selected facilities including B-Plant.

Total steam production capacity in the 300 Area is $240,000 \mathrm{Lbs} . / \mathrm{hr}$. Production capability based on availability of equipment, personnel and resources for FY 1996 is $140,000 \mathrm{Lbs}$./hr. which will match anticipated winter peak demand. The 300 Area steam facility also provides central compressed air with a capacity $/$ capability of $6,600 \mathrm{cfm}$. The FY 1996 demand for compressed air is expected not to exceed $800 \mathrm{cfm}$.

Backup electrical generation and distribution for 300 Area facilities is provided through the steam function. Total capacity/capability is 5;000 kVA with a FY 1996 demand of between 2,500 and 3,250 kVA should it be needed.

Water supply systems for customers in the $100,200,300$, and 600 areas are provided. The system generally consist of pumping facilities on the Columbia River, water treatment and supply in for the 200 Area and 300 Area, and oversight of various ground water pumping facilities and water treatment facilities for water use.

Water pumping capacity from the river is $99,000 \mathrm{gpm}$ in the 100 Areas and $20,000 \mathrm{gpm}$ in the 300 Area. Water treatment capacity in the $200 \mathrm{~W}$ Area is $2,600 \mathrm{gpm}$ with average flow demand between 300 and $500 \mathrm{gpm}$. Water treatment capacity in the 200E Area is also 2,600 gpm but has an average flow demand between 800 and $875 \mathrm{gpm}$. Water treatment capacity of the 300 Area is $3,200 \mathrm{gpm}$ with average flow demand between 1,000 and $1,450 \mathrm{gpm}$. Water supply capability will be maintained to meet average demands including anticipated peak use demands. The supply systems will also be maintained to meet fire protection requirements of facilities served.

A water administration function is provided to ensure the $200,300,600$, and 400 Areas potable water systems are in accordance with applicable drinking water standards and regulations. Technical support is provided to owners of water systems in the $100 \mathrm{~K}$ and $100 \mathrm{~N}$ Areas. 
Electrical supply system for the site is provided. The system generally consists of . 207 miles of distribution lines, 134 substations and a Supervisory, Control, and Data Acquisition (SCADA) system. Electrical power is mainly obtained from the Bonneville Power Administration by connection with offsite transmission lines.

The 100/200 Area electrical system has a usable capacity of $195 \mathrm{MW}$. The anticipated coincidental peak demand is $27.9 \mathrm{MW}$. The 300 Area electrical system has a usable capacity of $22.0 \mathrm{MW}$ with an anticipated coincidental peak demand of $13.6 \mathrm{MW}$.

Liquid Sanitary Waste systems are provided in support of facilities throughout the site. The systems consists mainly of septic tanks and drainfields in the 200 Area, septic tanks and drainfields in outlying facilities, a sanitary waste lagoon in the $100 \mathrm{~N}$ Area, a central collection system in the 300 Area connected to the City of Richland, septic tanks and drainfields in the 400 Area, and septic tanks in the 100 Areas. Operation, engineering and maintenance services are provided to owners of waste systems via this function.

Sanitary solid waste handling and disposal is provided for the site. Collection of waste from some 300 dumpsters, collection of wastes from miscellaneous containers (luggers), and transportation of the wastes for burial. Operation and management of site burial grounds including the central waste landfill and inert waste landfill is included in FY 1996. The central waste landfill is expected to cease operation in FY 1996 and waste disposal (burial) will be provided by others through contracts. Waste disposal volume is expected to. be 30,000 cubic yards of municipal waste and 50,000 cubic yards of inert waste in FY 1996.

\subsubsection{Transportation [WBS 6.8.2]}

Transportation operates, maintains, and provides services to provide for current and projected needs of the Hanford Site in the areas of road, railroad, and vehicles/equipment.

The transportation equipment fleet is composed of approximately 4,250 items described collectively as Hanford Operations (HO) coded equipment. Government-owned vehicles, heavy mobile equipment, and railroad rolling stock are included in the inventory. Replacement schedules are prepared according to vehicle age, mileage, annual percentage of fleet replacements allowed, and repair/replace guidance.

The Hanford Railroad System trackage is in generally sound and well maintained condition. Of the in service trackage (B, C, D, E line tracks of the Hanford Site Railroad System and portions of the A line track) $81 \%$ or 115.87 kilometers ( 72 miles) has been upgraded over the last 10 years. If maintenance is continued at the present level, the Hanford Site Railroad System trackage should support all foreseeable Site needs for transport of materials by railroad. Administrative controls are established for out-of-standard trackage to assure safe operation pending repair or upgrade of the suspect trackage. The current backlog of maintenance and repair tasks is at an acceptable level and is expected to remain stable with current funding levels. 
The condition of the Hanford Site roads varies. The majority of the paved roads on the Hanford Site fall into two distinct categories with respect to meeting current Washington State highway standards. The roads located south of the Wye Barricade meet current standards, while most of the roads north of the Wye Barricade do not. Future impacts to Site and area road systems will depend largely on the extent and scope of waste management and environmental cleanup activities. Additional heavy truck traffic loads generated by the construction and operation of the Tank Waste Remediation System, Waste Receiving and Packaging, and Environmental Restoration Disposal Facilities will require rehabilitation of the road system north of the wye barricade.

\subsubsection{General Purpose Facilities [WBS 6.8.3]}

General purpose facilities are defined as those facilities where no more than $60 \%$ of the building's use is dedicated to a single program. These facilities comprise $51 \%$ of the total building square footage on the Hanford Site and include office facilities, laboratories, shops, warehouses, and other special purpose space (i.e., change rooms and training facilities).

The physical condition of Hanford's general purpose buildings varies and is nearing almost half of its physical life. Even when the structural integrity of these facilities is not at issue, required technological upgrades or system replacements are often not economical or cost effective to complete.

Office space is critical to the administration of the cleanup mission at Hanford. Office population and office space needs are expected to decline relative to future site funding levels. In order to manage office space requirements during the rampdown, a balance between government-owned and commercial leased facilities must be maintained. This balance will allow for maximum flexibility in reacting to future funding changes and effective management of aging government-owned facilities. The balance will provide the basis for a smooth and healthy economic transition in the private sector.

Based on the most recent Site population reductions and forecasts, there is a current and projected surplus of office space across the site. In addition, home based office work could become a reasonable alternative for a growing number of support personnel as telecommunications networks are built throughout the community.

As the need for older, substandard government-owned facilities declines they must be vacated, shutdown, and demolished.

This WBS element also includes roads and grounds maintenance within the 200, 300, $400,600,700$ and 1100 Areas. This includes road, sidewalk, and parking lot maintenance, snow removal, weed control, tumbleweed removal, fence repairs, and general area cleanup. 


\subsubsection{Services [WBS 6.8.4]}

Services provides support in crane and rigging, fabrication, program services, laundry, environmental, safety and administration, and transportation services. The services contained in this document reflect the following types of support:

Crane and Rigging Services support is provided through the lifting, handling, movement, and placement of material and equipment; inspection and record maintenance of lifting equipment; erection, inspection; and removal of scaffold; fabrication, testing and control of below the hook rigging equipment; and the management of mobile lifting equipment.

Fabrication Services supports fabrication and repair of parts, components, and specified equipment including items contaminated with low level radiation. Specific emphasis is placed on prototype and emergency work that requires extensive engineering and manufacturing coordination required for critical area or program projects.

Program Integration customers are supported in areas where the program groups have no maintenance support or where, for matters of economics and/or jurisdictional considerations, the proper bargaining unit craft is not available to support programmatic needs. Maintenance support to these programmatic areas and functions includes but is not limited to craft labor, supplied tools, shop machinery support, and supervisory and planning aid.

Laundry Contract Management serves as the technical monitor for the DOE-RL laundry services contract. The contract provides for cleaning, transportation, and inspection of all respirators, radioactive protective, and non-regulated clothing used by DOE-RL contractors and subcontractors sitewide. Inspection of laundry pickup and delivery stations, and random laundry bag and respirator box sampling, insure contract requirements are being met.

Environmental Services (North and South) provides a complete range of environmental services to ICF Kaiser Hanford and some Westinghouse Hanford facilities and programs to ensure compliance with environmental regulations.

The Technical Services organization provides external and internal organizations with self assessment services, and administrative support for new technical activities, and technical support to cleanup activities.

Transportation Services provides office move services for all Hanford Site employees and a variety of special delivery services to all Hanford Site contractor facilities within the Tri-City area. 


\subsubsection{Energy Management [WBS 6.8.5]}

Energy Management provides guidance, direction, review, and innovative solutions for resource conservation activities. This ensures use of energy and water resources in the most efficient manner for all mission areas, as well as nearby communities and other Department of Energy sites.

\subsubsection{Program Integration [WBS 6.8.6]}

Program Integration provides overall coordination of infrastructure requirements, cost, schedule, and technical baseline development. Annual congressional budget submittal and infrastructure baseline integration are also provided. 
Table 2-1. Staffing and Cost Baseline Summary

\begin{tabular}{|c|c|c|c|c|c|c|}
\hline \multirow[b]{2}{*}{ WBS } & \multirow[b]{2}{*}{ Function } & \multicolumn{3}{|c|}{ FTES } & & \\
\hline & & Exempt & $\begin{array}{c}\text { Non- } \\
\text { Exempt }\end{array}$ & Bargaining & $\begin{array}{l}\text { Total } \\
\text { FIES }\end{array}$ & $\begin{array}{c}\text { Cost } \\
\text { Baseline }\end{array}$ \\
\hline
\end{tabular}

INFRASTRUCTURE PROGRAMS

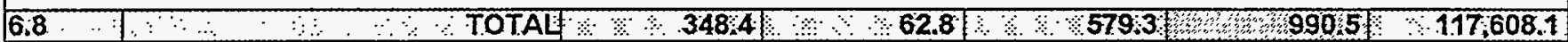

POOLS AND SERVICES

\begin{tabular}{|c|c|c|c|c|c|c|}
\hline \begin{tabular}{|l|}
$6: 8.1 \cdot 1$ \\
6.8 .1 .1 \\
6.8 .1 .2 \\
6.8 .1 .3 \\
6.8 .1 .4 \\
6.8 .1 .5 \\
6.8 .1 .6
\end{tabular} & \begin{tabular}{|l} 
Utilities \\
200 Area Steam \\
300 Area Steam \\
Water Utilities \\
Electrical Utilities \\
Sanitary Sewer \\
Sanitary Solid Waste
\end{tabular} & \begin{tabular}{r|}
110.8 \\
26.6 \\
19.4 \\
31.4 \\
31.1 \\
1.0 \\
1.3
\end{tabular} & $\begin{array}{r}13.4 \\
2.3 \\
2.2 \\
2.9 \\
5.5\end{array}$ & $\begin{array}{r}127.7 \\
40.3 \\
24.6 \\
37.5 \\
20.0 \\
2.0 \\
3.3\end{array}$ & $\begin{array}{r}2519 \\
69.2 \\
46.2 \\
71.8 \\
56.6 \\
3.0 \\
51\end{array}$ & $\begin{array}{r}30 ; 415.7 \\
9,821.6 \\
5,700.2 \\
8,191.5 \\
5,646.2 \\
0.0 \\
1,056.2\end{array}$ \\
\hline $\begin{array}{l}8.2 \\
8.2 .1 \\
8.2 .2 \\
8.2 .3\end{array}$ & $\begin{array}{l}\text { Transportation } \\
\text { Roads } \\
\text { Rails } \\
\text { Vehicles/Equipment }\end{array}$ & $\begin{array}{l}9: 9 \\
1.4 \\
2.1 \\
6.4\end{array}$ & $\begin{array}{r}13.6 \\
0.5\end{array}$ & $\begin{array}{r}70.7 \\
9.9 \\
13.5 \\
47.3\end{array}$ & $\begin{array}{r}84.2 \\
11.8 \\
15.6 \\
56.8\end{array}$ & $\begin{array}{r}12,867.4 \\
1,958.6 \\
1,363.7 \\
9,545.1\end{array}$ \\
\hline $\begin{array}{l}8.3 \\
8.3 .1 \\
.3 .2 \\
8.3 .3\end{array}$ & $\begin{array}{l}\text { Purpose Facilities: } \\
\text { Administration } \\
\text { Grounds }\end{array}$ & \begin{tabular}{r|}
$\% 72.6$ \\
68.2 \\
2.0 \\
2.4
\end{tabular} & $\frac{19.8}{18.7}$ & $\begin{array}{r}1.82: 8 \\
96.1 \\
0.0 \\
6.7\end{array}$ & $\begin{array}{r}195.2 \\
183,0 \\
2.3 \\
9.9\end{array}$ & $\begin{array}{r}31,121.2 \\
12,443.6 \\
1,469.9\end{array}$ \\
\hline$\frac{6.8 .4}{6.8 .4 .1}$ & $\begin{array}{l}\text { Services: } \\
\text { Crane \& Rigging } \\
\text { Fabrication } \\
\text { Programmatic } \\
\text { Laundry } \\
\text { Environmental } \\
\text { Transportation Services } \\
\text { Technical Services }\end{array}$ & \begin{tabular}{|r|}
82.8 \\
12.0 \\
17.5 \\
13.6 \\
5.1 \\
27.0 \\
2.0 \\
5.6
\end{tabular} & $\begin{array}{r}10.3 \\
1.5\end{array}$ & $\begin{array}{r}244.1 \\
39.0 \\
61.0 \\
112.4 \\
0.0 \\
0.0 \\
31.7 \\
0.0\end{array}$ & $\begin{array}{r}337.2 \\
52.5 \\
78.5 \\
132.8 \\
6.1 \\
27.0 \\
34.7 \\
5.6\end{array}$ & $\begin{array}{r}10 ; 833.1 \\
5,266.4 \\
0.0 \\
0.0 \\
2,865.7 \\
0.0 \\
2,701.0\end{array}$ \\
\hline
\end{tabular}

Note: Services includes dollars for Crane and Rigging, Laundry, and Transportation Services because they are pools. Other senvices are direct funded and show no dollars

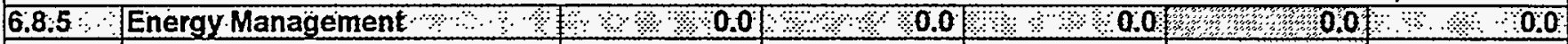

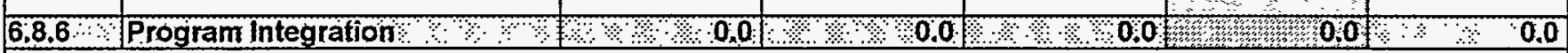

ORGANIZATION OVERHEAD

\begin{tabular}{|c|c|c|c|c|c|c|}
\hline \multirow{3}{*}{$\begin{array}{l}\text { WBS } \\
6.8 .6: \\
\end{array}$} & \multirow{3}{*}{$\begin{array}{l}\text { Function } \\
\text { Department Overhead }\end{array}$} & \multicolumn{3}{|c|}{ FTES } & \multirow{3}{*}{$\begin{array}{l}\text { Total } \\
\text { FTES } \\
\text { FI220 }\end{array}$} & \multirow{3}{*}{$\begin{array}{c}\text { Cost } \\
\text { Basel/ne }\end{array}$} \\
\hline & & Exempt & $\begin{array}{c}\text { Non- } \\
\text { Exempt }\end{array}$ & Bargaining & & \\
\hline & & $\%: 72: 3$ & $2 \quad 15: 7$ & $1.4 \% 34.0$ & & \\
\hline 6.8 .6 & Utilities Division & 6.0 & 1.5 & 0.0 & 7.5 & 763.7 \\
\hline 6.8 .6 & $\begin{array}{l}\text { Transportation \& Waste } \\
\text { Handling Department }\end{array}$ & 29.6 & 5.2 & 20.0 & 54.8 & $5,257.4$ \\
\hline 6.8 .6 & Facilities \& Site Services Dept. & 31.2 & 7.0 & 14.0 & 52.2 & $11,804.3$ \\
\hline 6.8 .6 & Infrastructure Programs Division & 5.5 & 2.0 & 0.0 & 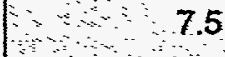 & 631.8 \\
\hline
\end{tabular}




\begin{tabular}{|c|c|c|c|c|c|c|c|c|c|}
\hline $\begin{array}{l}\text { Work } \\
\text { Breakdown } \\
\text { Structure } \\
\text { Dictionary }\end{array}$ & \multicolumn{6}{|c|}{$\begin{array}{c}\text { Westinghouse Hanturd Company } \\
6.8 \text { Summary } \\
\text { Part } 1 \text { - Summary } \\
\text { (Dollars in 000's) }\end{array}$} & \multicolumn{3}{|c|}{$\begin{array}{l}\text { FY } 1996 \\
\text { Indirect } \\
\text { Program Plan } \\
\text { Rev. \# } 0 \\
25-\text { Sep-95 }\end{array}$} \\
\hline Cost Account Number & \multicolumn{6}{|c|}{$\begin{array}{l}\text { Cost Account Title } \\
6.8 \text { Summary }\end{array}$} & \multicolumn{3}{|c|}{$\begin{array}{l}\text { Proposed Rate: } \\
\text { (Rated Service Pool Only) }\end{array}$} \\
\hline $\begin{array}{l}\text { SMS WBS Number } \\
6.8 \\
\end{array}$ & \multicolumn{6}{|l|}{$\begin{array}{l}\text { SMS Title } \\
6.8 \text { Summary }\end{array}$} & \multicolumn{3}{|c|}{ Funding Source: } \\
\hline RL SMS Program Manager & \multicolumn{6}{|c|}{ W.A. Rutherford } & \multicolumn{3}{|l|}{ sws } \\
\hline Cost Account Manager & \multicolumn{6}{|l|}{ G.A. Harvey } & \multicolumn{3}{|l|}{ OST } \\
\hline WHC SMS Program Manager & \multicolumn{6}{|l|}{ G.A. Harvey } & \\
\hline Financial Manager & \multicolumn{6}{|l|}{ M.A. Davis } & & \multicolumn{2}{|c|}{$\begin{array}{l}\text { MGT PRO } \\
001 x\end{array}$} \\
\hline Responsible Analyst & \multicolumn{3}{|c|}{$\begin{array}{l}\text { FY } 1996 \text { Approved Funding } \\
\text { Full-Time Equivalents (FTEs) }\end{array}$} & \multicolumn{3}{|c|}{$\begin{array}{l}\text { FY } 1996 \text { Unfunded } \\
\text { Full-Time Equivalents (FTEs) }\end{array}$} & \multicolumn{3}{|c|}{$\begin{array}{c}\text { POOL } x \\
\text { FY } 1996 \text { Baseline } \\
\text { Full-Time Equivalents (FTEs) }\end{array}$} \\
\hline TYPE OF FTE & Exempt & Non-Exempt & Bargaining & Exempt & \begin{tabular}{|l|} 
Non-Exempt \\
\end{tabular} & Bargaining & Exempt & Non-Exempt & Bargaining \\
\hline Organizational & 301.5 & 56.7 & 550.4 & 11.3 & 5.0 & 29.0 & 312.8 & 61.7 & 579.4 \\
\hline Support & 46.9 & 6.1 & 28.9 & 14.7 & 3.0 & 4.2 & 61.6 & 9.1 & 33.1 \\
\hline TOTALFTES & 348.4 & 62.8 & 579.3 & 26.0 & 8.0 & 33.2 & 374.4 & 70.8 & 612.5 \\
\hline COST ELEMENTS & \multicolumn{3}{|c|}{ FY 1996 Approved Funding Budget } & \multicolumn{3}{|c|}{ FY 1996 Unfunded Budget } & \multicolumn{3}{|c|}{ FY 1996 Baseline Budget } \\
\hline . Labor-Regular & \multicolumn{2}{|c|}{ 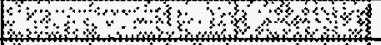 } & $44,890.4$ & \multicolumn{2}{|c|}{$\%, 3, \ldots, \%$} & 825.7 & \multicolumn{2}{|c|}{$40,1,1, \times 1 \times 8$} & $45,716.1$ \\
\hline Labor - Overtime & \multirow{2}{*}{\multicolumn{2}{|c|}{$40,43 \%, 4 \%$}} & $1,388.1$ & \multicolumn{2}{|c|}{$34,10,2,1$} & 4.3 & \multicolumn{2}{|c|}{$0<20001$} & $\overline{1,392.4}$ \\
\hline 0 Total Labor & & & $46,278.5$ & \multicolumn{2}{|c|}{ 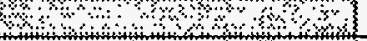 } & 830.0 & \multicolumn{2}{|c|}{$6 \%, \%, 8 \%$} & $47,108.5$ \\
\hline 1 Materials & \multicolumn{2}{|c|}{$00 \%$ का } & $8,501.2$ & $62+3$ & 4,30 & 2.0 & \multicolumn{2}{|c|}{$40,0 \times 8$} & $8,503.2$ \\
\hline 2 Purchased Services & 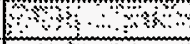 & 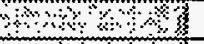 & $8,278.6$ & $8 \times 20$ & $3 \times 3$ & 0.0 & 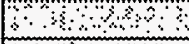 & 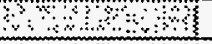 & $8,278.6$ \\
\hline 3 Other Hanford & $1+2$ & ए। & $8,731.0$ & कि & 3 & 2.5 & 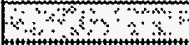 & $301 \%$ & $8,733.5$ \\
\hline 8 Revenue & 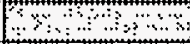 & $+\infty$ & $(2,080.5)$ & 80 & & 0.0 & 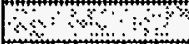 & $2+3$ & $(2,080.5$ \\
\hline Subtotal Originated Costs & +3 & 48 & 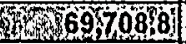 & $3-3$ & & 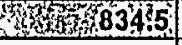 & 43 & & $10,70,543.3$ \\
\hline 4 Site Services & 1, & 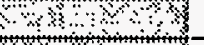 & $27,420.7$ & 6,18 & 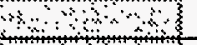 & 30.0 & 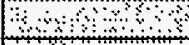 & 16. $\div$ & $27,450.7$ \\
\hline 5 Internal Charges & 00 & 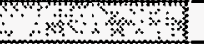 & $8,031.6$ & 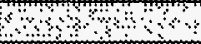 & $6+3$ & 0.0 & $8 \times 10$ & 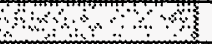 & $8,031.6$ \\
\hline 6 IRM Support & 8 & $6 \%$ & $2,076.9$ & 6 & 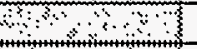 & 3.2 & 6 & 2 & $2,080.1$ \\
\hline 7 Overheads & $58+8$ & $33 \times 3$ & $10,370.1$ & $3+2$ & 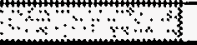 & 145.4 & एwi & $3+4=3$ & $10,515.5$ \\
\hline TOTAL DOLLARS & 83 & 3.6 & $117,608.1$ & 3 & $3+53$ & $1,013.1$ & 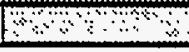 & 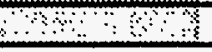 & $118,621.2$ \\
\hline $\begin{array}{l}\text { SIGNATURES } \\
\text { Financial Analyst: } \\
\text { CAM: }\end{array}$ & & -5 & $\begin{array}{l}\text { Date: } \\
\text { Date: }\end{array}$ & & BASELINEAPF & PROVAL & & & Date: \\
\hline
\end{tabular}




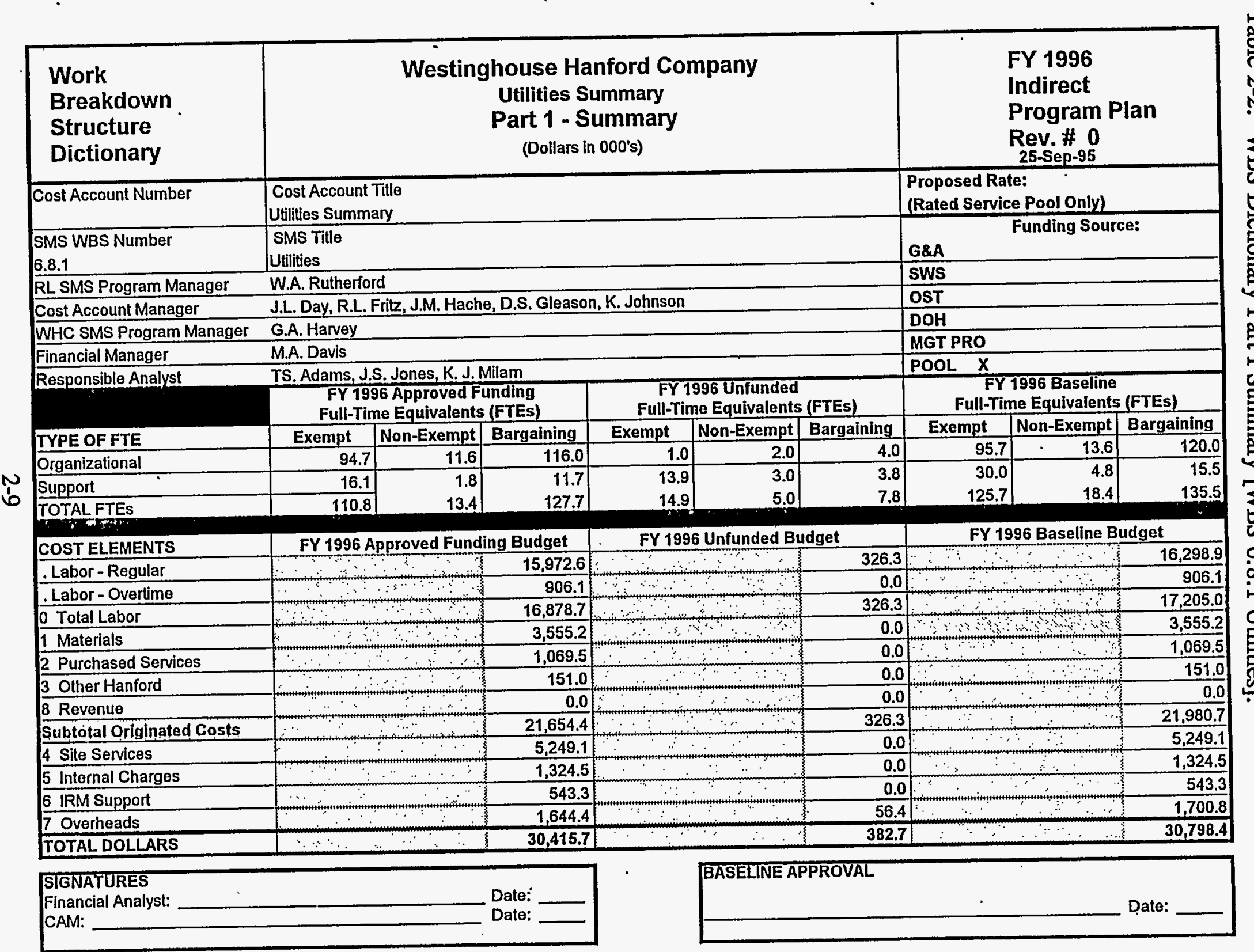




\begin{tabular}{|c|c|c|c|c|c|c|c|c|}
\hline $\begin{array}{l}\text { Work } \\
\text { Breakdown } \\
\text { Structure } \\
\text { Dictionary }\end{array}$ & \multicolumn{5}{|c|}{$\begin{array}{l}\text { Westinghouse Hanford Company } \\
\text { Transportation Summary } \\
\text { Part } 1 \text { - Summary } \\
\text { (Dollars in 000's) }\end{array}$} & \multicolumn{3}{|c|}{$\begin{array}{l}\text { FY } 1996 \\
\text { Indirect } \\
\text { Program Plan } \\
\text { Rev. \# } 0 \\
25-\text { Sep-95 }\end{array}$} \\
\hline Cost Account Number & \multicolumn{5}{|c|}{$\begin{array}{l}\text { Cost Account Title } \\
\text { Transportation Summary }\end{array}$} & \multicolumn{3}{|c|}{$\begin{array}{l}\text { Proposed Rate: } \\
\text { (Rated Service Pool On(y) }\end{array}$} \\
\hline $\begin{array}{l}\text { SMS WBS Number } \\
6.8 .2\end{array}$ & \multicolumn{5}{|c|}{$\begin{array}{l}\text { SMS Title } \\
\text { Transportation Summary }\end{array}$} & \multicolumn{3}{|c|}{ Funding Source: } \\
\hline RL SMS Program Manager & \multicolumn{5}{|c|}{ W.A. Rutherford } & \multicolumn{3}{|l|}{ sws } \\
\hline Cost Account Manager & \multicolumn{5}{|c|}{ A.C. Metz, R.G. Ciccone, J.F. Woods } & \multicolumn{3}{|l|}{\begin{tabular}{|l|l|} 
OST \\
\end{tabular}} \\
\hline WHC SMS Program Manager & \multicolumn{5}{|l|}{ G.A. Harvey } & \\
\hline Financial Manager & \multicolumn{5}{|l|}{ M.A. Davis } & \multicolumn{3}{|l|}{ MGT PRO } \\
\hline Responsible Analyst & \multicolumn{5}{|c|}{ RF Hilbert, K.J Milam } & \multirow{2}{*}{\multicolumn{3}{|c|}{\begin{tabular}{|c|c|} 
POOL & $x$ \\
FY 1996 Baseline \\
FuIfqin e Equidalents (FTES)
\end{tabular}}} \\
\hline H. & \multicolumn{3}{|c|}{$\begin{array}{l}\text { FY } 1996 \text { Approved Funding } \\
\text { Full-Time Equivalents (FTEs) }\end{array}$} & \multicolumn{2}{|c|}{$\begin{array}{l}\text { FY } 1996 \text { Unfunded } \\
\text { Full-Time Equivalents (FTEs) }\end{array}$} & & & \\
\hline TYPE OF FTE & Exempt & \begin{tabular}{|l|} 
Non-Exempt \\
\end{tabular} & Bargaining & \begin{tabular}{l|l|} 
Exempt & Non-Exempt \\
\end{tabular} & Bargaining & Exempt & Non-Exempt & Bargaining \\
\hline Organizational & 8.5 & 3.5 & 64.1 & 0.0 & 0.0 & 8.5 & 3.5 & 64.1 \\
\hline Support & 1.4 & 0.1 & 6.6 & 0.0 & 0.0 & 1.4 & 0.1 & 6.6 \\
\hline TOTALFTES & 9.9 & 3.6 & 70.7 & 0.0 & 0.0 & 9.9 & 3.6 & 70.7 \\
\hline COST ELEMENTS & FY $1996 \mathrm{AI}$ & pproved Fundir & ing Budget & FY 1996 Unfunded Bu & Idget & FY 19 & 996 Baseline Bu & udget \\
\hline . Labor - Regular & \%०\% & 111 & $4,621.8$ & एक & 0.0 & \$1 & $8 \times 103$ & $4,621.8$ \\
\hline . Labor-Overtime & ? & 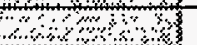 & 100.4 & $2+3 \%$ & 0.0 & ப-. & 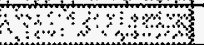 & 100.4 \\
\hline 0 Total Labor & $6 n$ & 34 & $4,722.2$ & की & 0.0 & 13 & 30 & $4,722.2$ \\
\hline 1 Materials & ३००४ & कारा & $2,805.9$ & की & 0.0 & 33 & 864 & $2,805.9$ \\
\hline 2 Purchased Services & $23 \times 3 \%$ & 303 & 3.5 : & $4 \times 3,26,8$ & 0.0 & $6 x+2$ & 3201 & 3.5 \\
\hline 3 Other Hanford & ४ैमे & मा & 25.0 & अ००००? & 0.0 & बिख & $616 \%$ & 25.0 \\
\hline 8 Revenue & 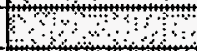 & 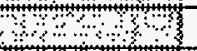 & $(2,080.5)$ & ४००० $<$ & 0.0 & 83 & 30 & $(2,080.5)$ \\
\hline Subtotal Orlginated Costs: & $2+40$ & $3 \times 2,3$ & H5i46:14 & $3,4,4, \quad 3,4$ & 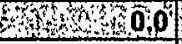 & +10 & $3+4$ & $5,476.1$ \\
\hline 4 Site Services & $2 x+3$ & $4+3$ & $1,947.0$ & 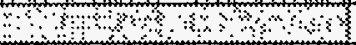 & 0.0 & 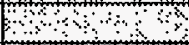 & 48 & $1,947.0$ \\
\hline 5 Internal Charges & + & 32 & $3,571.3$ & की, & 0.0 & $6 \%$ & $3+6$ & $3,571.3$ \\
\hline 6 IRM Support & 84 & 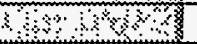 & 33.3 & $6 \%$ & 0.0 & 6 & ए। & 33.3 \\
\hline 7 Overheads & 3.3 & 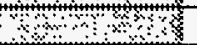 & $1,839.7$ & $8 B \sin (4)$ & 0.0 & 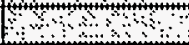 & $240 \%, 6$ & $1,839.7$ \\
\hline TOTAL DOLLARS & 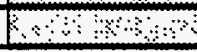 & 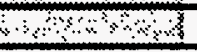 & $12,867.4$ & (20 & 0.0 & 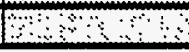 & 008 & $12,867.4$ \\
\hline $\begin{array}{l}\text { SIGNATURES } \\
\text { Financial Analyst: } \\
\text { CAM: }\end{array}$ & & & $\begin{array}{l}\text { Date: } \\
\text { Date: }\end{array}$ & BASELINEAP & PROVAL & & & te: \\
\hline
\end{tabular}




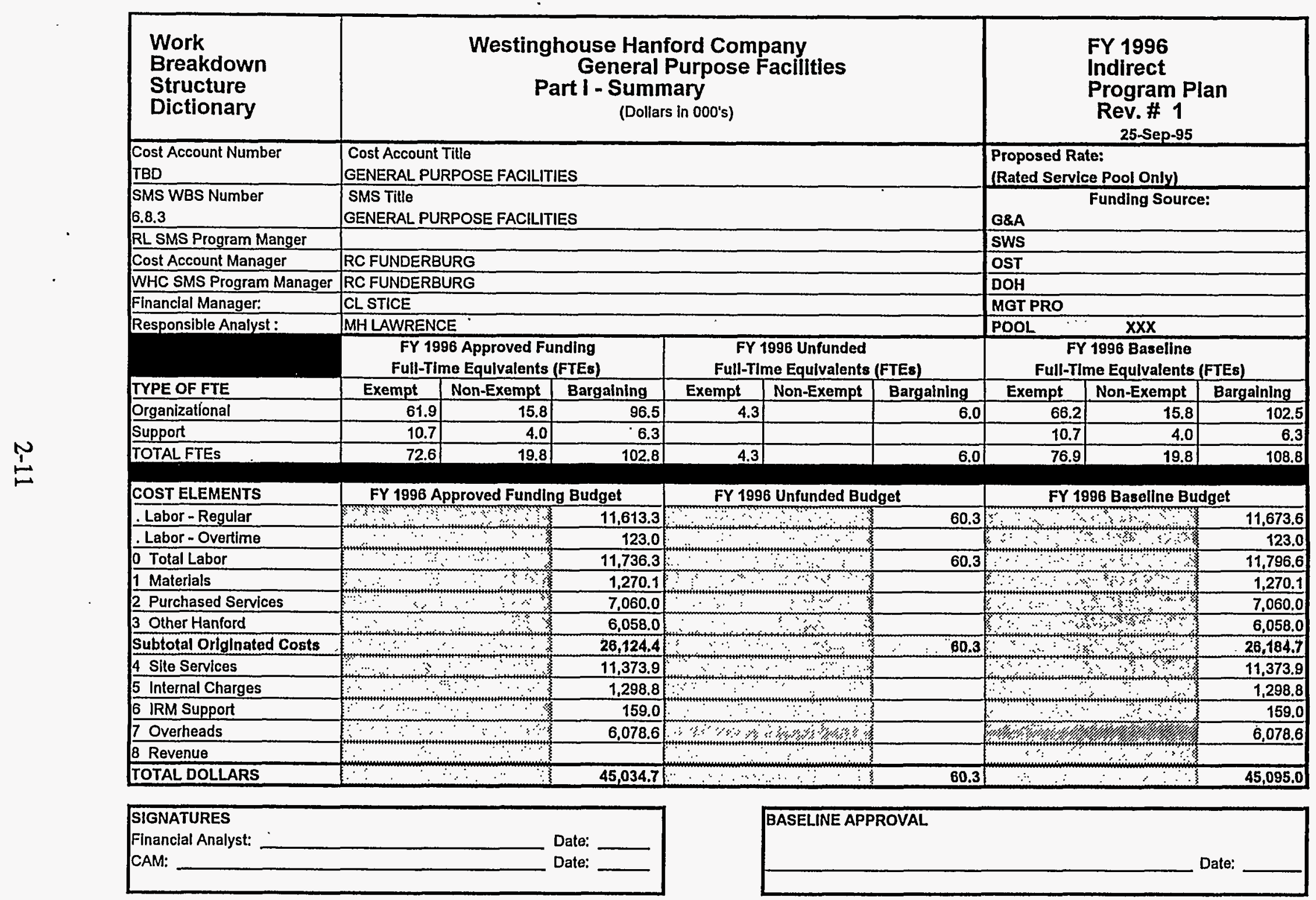




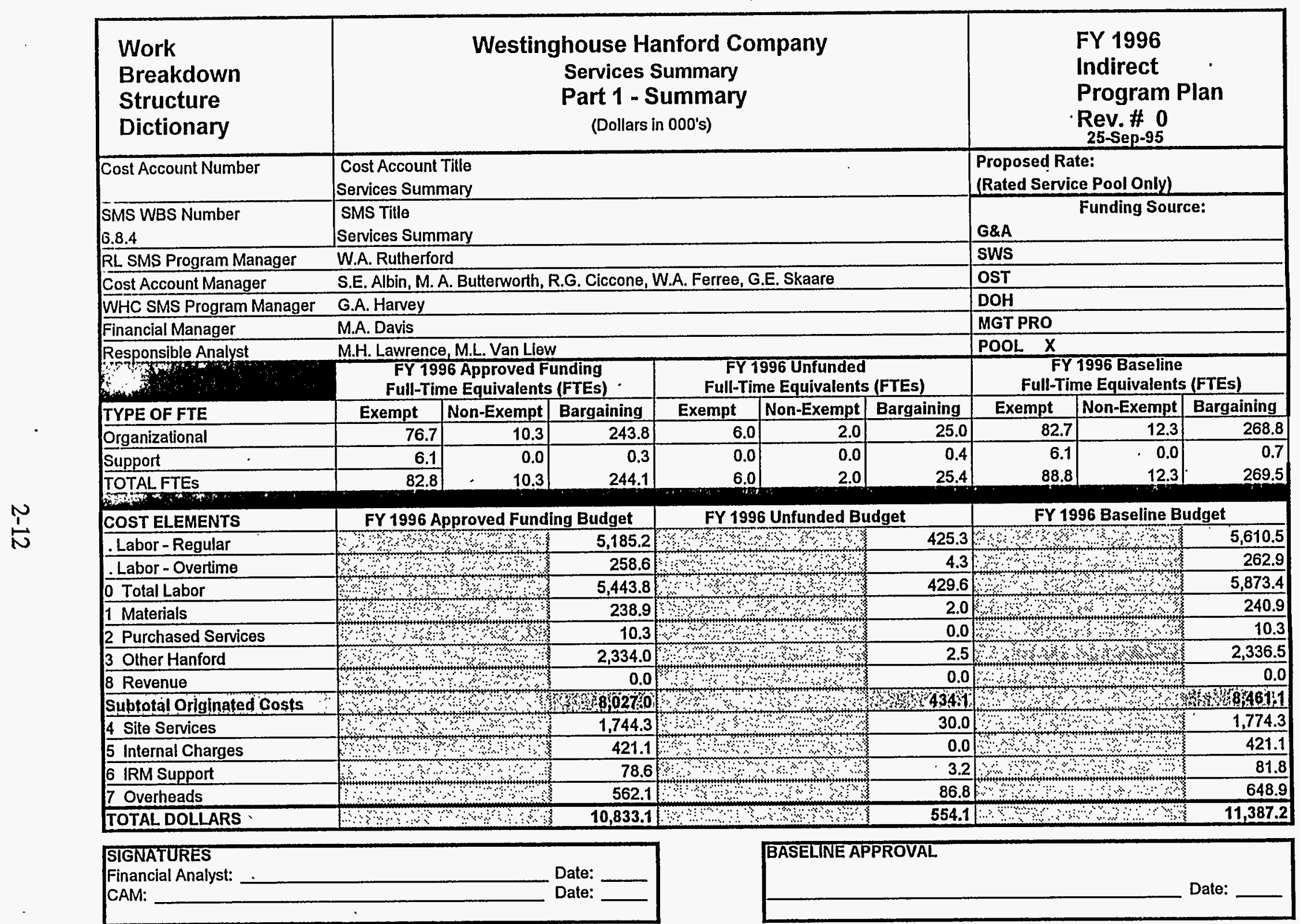




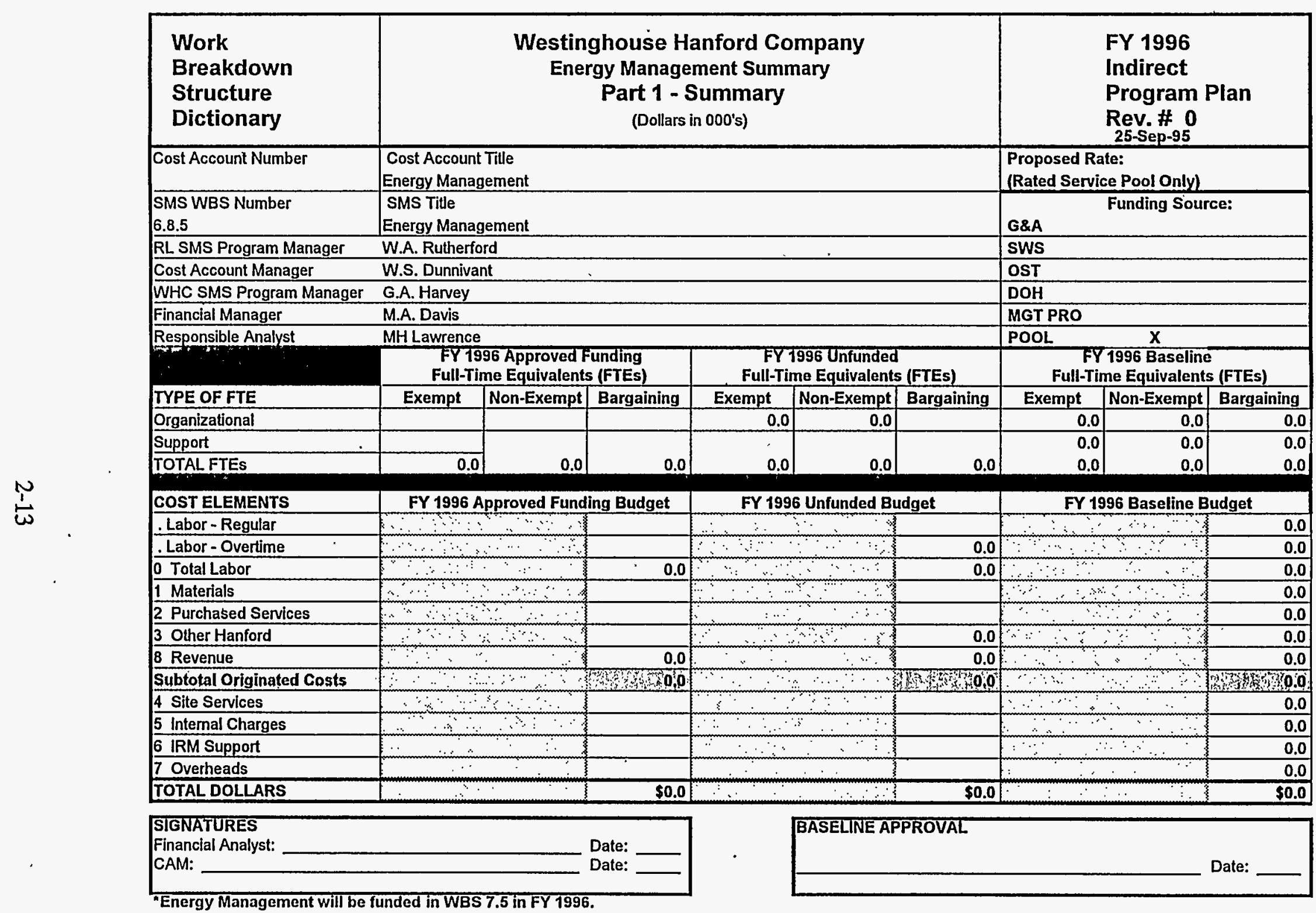




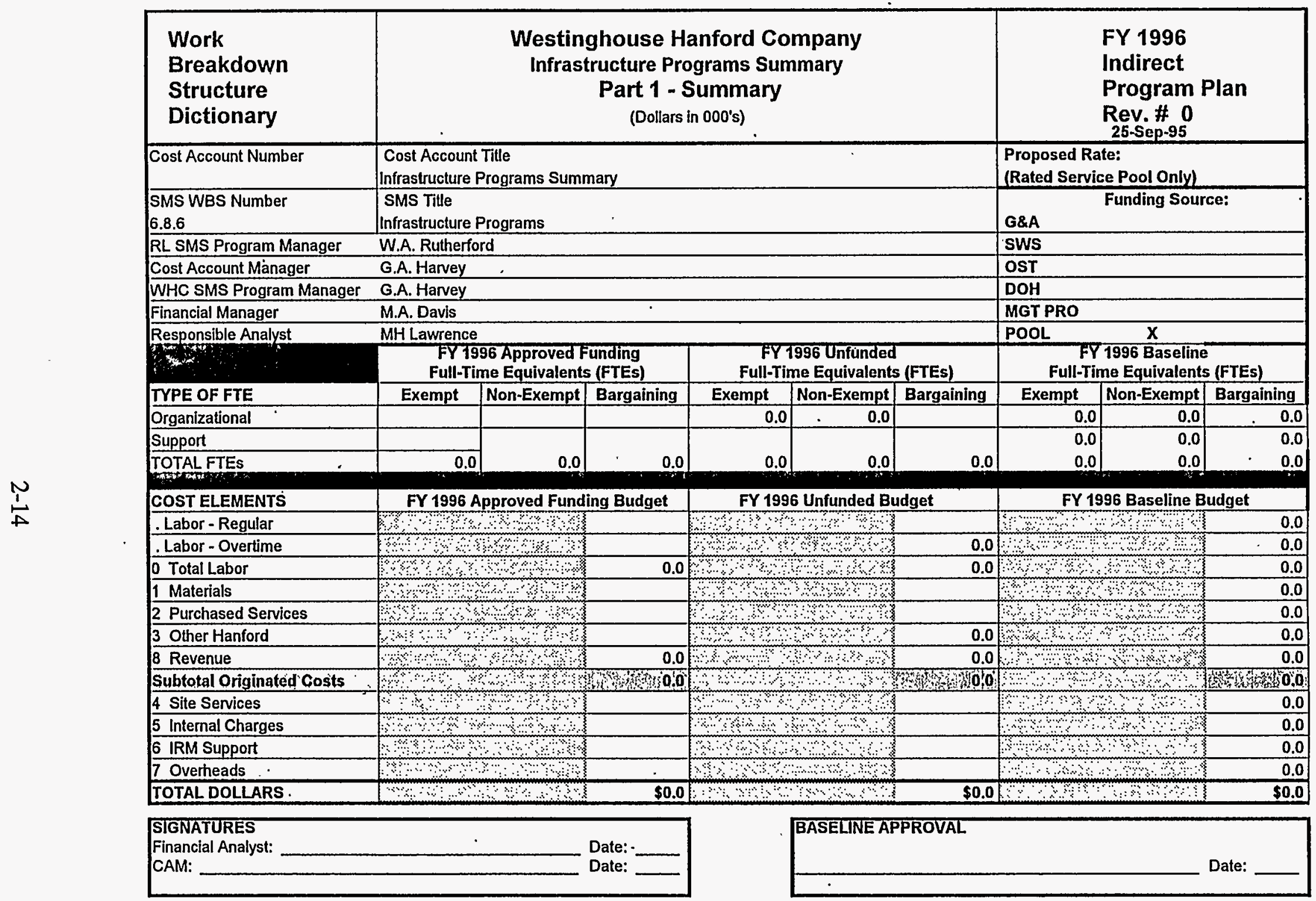




\begin{tabular}{|c|c|c|c|c|c|c|c|c|c|}
\hline $\begin{array}{l}\text { Work } \\
\text { Breakdown } \\
\text { Structure } \\
\text { Dictionary }\end{array}$ & \multicolumn{6}{|c|}{$\begin{array}{c}\text { Westinghouse Hanford Company } \\
\text { Department Overhead Summary } \\
\text { 'Part } 1 \text { - Summary } \\
\text { (Dollars in 000's) }\end{array}$} & \multicolumn{3}{|c|}{$\begin{array}{l}\text { FY } 1996 \\
\text { Indirect } \\
\text { Program Plan } \\
\text { Rev. \# } 0 \\
25-\text { Sep-95 }\end{array}$} \\
\hline Cost Account Number. & \multicolumn{6}{|c|}{$\begin{array}{l}\text { Cost Account Title } \\
\text { Department Overhead Summary }\end{array}$} & \multicolumn{3}{|c|}{$\begin{array}{l}\text { Proposed Rate: } \\
\text { (Rated Service Pool Only) }\end{array}$} \\
\hline $\begin{array}{l}\text { SMS WBS Number } \\
6.8 .6\end{array}$ & \multicolumn{6}{|c|}{$\begin{array}{l}\text { SMS Title } \\
\text { Department Overhead Summary }\end{array}$} & \multicolumn{3}{|c|}{ Funding Source: } \\
\hline RL SMS Program Manager & \multicolumn{6}{|c|}{ W.A. Rutherford } & \multicolumn{3}{|l|}{ Sws } \\
\hline Cost Account Manager & \multicolumn{6}{|c|}{ HL. Debban, JF Woods, RG Clccone, BA Holmberg, RM Tanner, MA Butterworth, GA Harvey } & \multicolumn{3}{|l|}{ OST } \\
\hline WHC SMS Program Manager & \multicolumn{6}{|l|}{ G.A. Harvey } & \multicolumn{3}{|c|}{\begin{tabular}{|l} 
DOH \\
\end{tabular}} \\
\hline Financial Manager & \multicolumn{6}{|l|}{ M.A. Davis } & \multicolumn{3}{|l|}{ MGT PRO } \\
\hline Responsible Analyst & $\begin{array}{l}\text { FY } 1996 \text { Approved funding } \\
\text { Full-Time Equivalents (FTEs) }\end{array}$ & \multicolumn{2}{|c|}{ RF Hilbert, ML Van Liew, JS Jones, MH Lawrence } & \multicolumn{3}{|c|}{$\begin{array}{l}\text { FY } 1996 \text { Unfunded } \\
\text { Full-Time Equivalents (FTEs) }\end{array}$} & \multicolumn{3}{|c|}{$\begin{array}{l}\text { POOL FY1996 Baseline } \\
\text { Full-Time Equivalents (FTES) }\end{array}$} \\
\hline TYPE OF FTE & Exempt & Non-Exempt & Bargaining & Exempt & Non-Exempt & Bargaining & Exempt & Non-Exempt & Bargaining \\
\hline Organizational & 59.7 & 15.5 & 30.0 & 0.0 & 1.0 & 0.0 & 59.7 & 16.5 & 30.0 \\
\hline Support & 12.6 & 0.2 & 4.0 & 0.8 & 0.0 & 0.0 & 13.4 & 0.2 & 4.0 \\
\hline TOTALFTES & 72.3 & 15.7 & 34.0 & 0.8 & 1.0 & 0.0 & 73.1 & 16.7 & 34.0 \\
\hline COST ELEMENTS & \multicolumn{3}{|c|}{ FY 1996 Approved Funding Budget } & \multicolumn{3}{|c|}{ FY 1996 Unfunded Budget } & \multicolumn{3}{|c|}{ FY 1996 Baseline Budget } \\
\hline . Labor-Regular & WX, & , & $7,497.5$ & $3<+3$ & (6) & 13.8 & & & $7,511.3$ \\
\hline . Labor - Overtime & $3<>3$ & $(3>1>1>1$ & 0.0 & 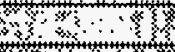 & 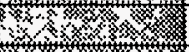 & 0.0 & $5 \quad 3$ & 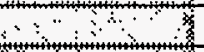 & 0.0 \\
\hline 0 Total Labor & 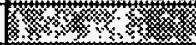 & 1.1. & $7,497.5$ & SOY & $1 \times 10$ & 13.8 & 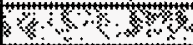 & $30+4$ & $7,511.3$ \\
\hline 1 Materials & 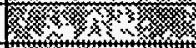 & 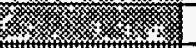 & 631.1 & b. & (x) & 0.0 & 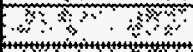 & $=x+8$ & 631.1 \\
\hline 2 Purchased Senvices & $(3,3-3.30$ & 30 & 135.3 & 3 & 供 & 0.0 & $8 \times+3$ & +1 & 135.3 \\
\hline 3 Other Hanford & (3) & 1. & 163.0 & 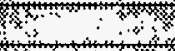 & $(x, y)$ & 0.0 & $w_{1}$ & $3+3$ & 163.0 \\
\hline 8 Revenue & 1 1. $-x, x<x$ & 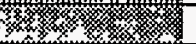 & 0.0 & $x \cdot 12$ & 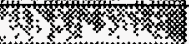 & 0.0 & $8 \%$ & (4) & 0.0 \\
\hline Subtotal Originated Costs & 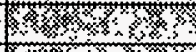 & ; & 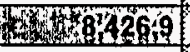 & 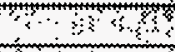 & $3 \times 3,3$ & $4613: 8$ & $\therefore \cdots$ & & 648440 \\
\hline 4 Sitte Services & 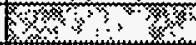 & (x) & $7,106.4$ & & तर & 0.0 & " & & $7,106.4$ \\
\hline 5 Internal Charges & $3 \%, \%$ & 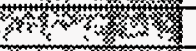 & $1,415.9$ & 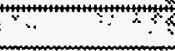 & 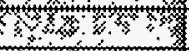 & 0.0 & 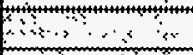 & & $1,415.9$ \\
\hline 6 IRM Support & (2) & 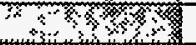 & $1,262.7$ & & ave & 0.0 & $\therefore$ & & $1,262.7$ \\
\hline 7 Overheads & $y$ & 3 & 245.3 & & & 2.2 & & & 247.5 \\
\hline TOTAL DOLLARS & $\because \cdots$ & 3 & $\$ 18,457.2$ & & 簀 & $\$ 16.0$ & & & $\$ 18,473.2$ \\
\hline $\begin{array}{l}\text { SIGNATURES } \\
\text { Financial Analyst: } \\
\text { CAM: }\end{array}$ & & c & $\begin{array}{l}\text { Date: } \\
\text { Date: }\end{array}$ & & BASELINEAP & PROVAL & & & \\
\hline
\end{tabular}




\subsection{WORK BREAKDOWN STRUCTURE AND RESPONSIBILITY} ASSIGNMENT MATRIX

\begin{tabular}{|c|c|c|c|c|c|}
\hline $\begin{array}{l}\text { PROGRAM } \\
\text { ELEMENT }\end{array}$ & ACTIVITY & $\begin{array}{c}\text { COST ACCOUNT } \\
\text { PLAN }\end{array}$ & TITLE & $\begin{array}{l}\text { RESPONSIBLE } \\
\text { MANAGER }\end{array}$ & $\begin{array}{l}\text { RESPONSIBLE } \\
\text { ORGANIZATION }\end{array}$ \\
\hline \multirow[t]{7}{*}{ \% $81 \%$} & \%.\%. & $\$$ & 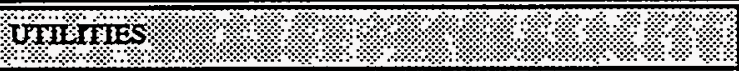 & EMYKoentron & \%ং IP: $: \%$ \\
\hline & 6.8 .1 .1 & & 200 AREA STEAM & Л Day 54200 & UTL \\
\hline & 6.8 .1 .2 & & 300 AREA STEAM & DS Gleason 54300 & UTL \\
\hline & 6.8 .1 .3 & & WATER & $\begin{array}{l}\text { JL Day } 54200 \\
\text { DS Gleason } 54300\end{array}$ & UTL \\
\hline & 6.8.1.4 & & ELECTRICAL & RL Fritz 54500 . & UTL \\
\hline & 6.8 .1 .5 & & SANITARY SEWERS & $\begin{array}{c}\pi \text { Day } 54200 \\
\text { DS Gleason } 54300\end{array}$ & UTL \\
\hline & 6.8.1.6 & & SANITARY SOLID WASTE & KD J̣ohnson 52310 & FSS \\
\hline \multirow[t]{4}{*}{6.82} & ?.: & $\%$ & TRANSSORTATHON .. . & R. Eyanoff: & $\mathrm{pp}$ \\
\hline & 6.8.2.1 & & ROADS & BA Holmberg 52300 & FSS \\
\hline & 6.8 .2 .2 & & RAII & BA Holmberg 52300 & FSS \\
\hline & 6.8 .2 .3 & & VEHICLE/EQUIPMENT & BA Holmberg 52300 & FSS \\
\hline \multirow[t]{4}{*}{ (6.8.3. } & $1.6 \%$ & 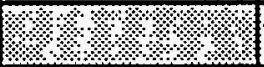 & GENEPALPURPOSE FACIITTIESS & . & ) \\
\hline & 6.8.3.1 & & GOVERNMENT BUILDINGS & RC Funderburg 52400 & FSS \\
\hline & 6.8 .3 .2 & . & LEASED BUILDINGS & RC Funderburg 52400 & FSS \\
\hline & 6.8 .3 .3 & & ROADS AND GROUNDS & WH Hays 52700 & FSS \\
\hline \multirow[t]{8}{*}{$6 \% \%$} & 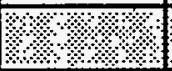 & (2., & 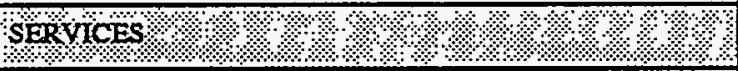 & MHpixson & $\%$ \\
\hline & 6.8.4.1 & & CRANE AND RIGGING & WA Ferree 52200 & FSS \\
\hline & 6.8 .4 .2 & & FABRICATION & $\begin{array}{l}\text { MA Butterworth } \\
52100\end{array}$ & FSS \\
\hline & 6.8 .4 .3 & & PROGRAMMATIC SERVICES & WH Hays 52700 & FSS \\
\hline & 6.8.4.4 & & LAUNDRY & SE Albin 56100 & $\mathbf{I P}$ \\
\hline & 6.8.4.5 & & ENVIRONMENTAL & GE Skaare 52800 & FSS \\
\hline & 6.8 .4 .6 & & TRANSPORTATION SERVICES & RG Ciccone 52300 & FSS \\
\hline & 6.8.4.7 & & TECHNICAL SERVICES & GE Skaare 52800 & FSS \\
\hline \multirow[t]{4}{*}{6.8 .5} & : & 1.6 .3 .3 & 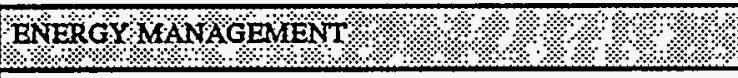 & พิs ponnivant $/$ & \%) $\mathrm{p}$ \% \\
\hline & 6.8.5.1 & & IN HOUSE ENERGY MANAGEMĖNT & WS Dunnivant 56200 & IP \\
\hline & 6.8 .5 .2 & & ENERGY SUPPORT & WS Dunnivant 56200 & IP \\
\hline & 6.8 .5 .3 & & ENERGY SERVICES & WS Dunnivant 56200 & $\mathbf{I P}$ \\
\hline \multirow[t]{4}{*}{686} & ?. & (2., \%? & PROGRAM NNTERRATON & , AD Gaderen & 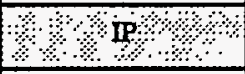 \\
\hline & 6.8.6.1 & & PROGRAM LEADERSHIP & AD Gadeken 56200 & IP \\
\hline & 6.8.6.2 & & PROGRAM SUPPORT & AD Gadeken 56200 & IP \\
\hline & 6.8 .6 .3 & & PROGRAM INTEGRATIÓN & AD Gadeken 56200 & IP \\
\hline
\end{tabular}




\begin{tabular}{|c|c|c|c|c|c|}
\hline $\begin{array}{l}\text { PROGRAM } \\
\text { ELEMENT }\end{array}$ & ACTIVITY & $\begin{array}{c}\text { COST ACCOUNT } \\
\text { PLAN }\end{array}$ & .TITLE & $\begin{array}{c}\text { RESPONSIBLE } \\
\text { MANAGER }\end{array}$ & $\begin{array}{c}\text { RESPONSIBLE } \\
\text { ORGANIZATION }\end{array}$ \\
\hline & 6.8 .6 .4 & & TRANSITION MANAGEMENT & AD Gadeken 56200 & IP \\
\hline & 6.8 .6 .5 & & INFRASTRUCTURE AND LAND USE PLANNING & AD Gadeken 56200 & IP \\
\hline
\end{tabular}

Responsible Organization Legend

-FSS Facility and Site Services

IP Infrastructure Programs

UTL Utilities 


\subsection{INFRASTRUCTURE PROGRAM ASSUMPTIONS AND CONSTRAINTS}

\subsubsection{Assumptions}

Although the infrastructure is aging, planning is based on as-needed maintenance and replacements only, with minimal upgrades or outyear mortgages.

Only normal anticipated operation, maintenance and administrative activities will occur during the planning period.

The infrastructure program plan is based on the assumption that all DOE order, regulations and requirements in effect at approval will remain the same throughout fiscal year 1996.

The current steam production operations in the 284-E and 384 facilities will be required for FY 1996 but will be terminated prior to FY 1997.

Electrical usage will not increase more than $10 \mathrm{MW}$ per year, thus, avoiding a penalty charge by the BPA. It is further assumed that electrical purchase rates will not increase more than $15 \%$ over the current established rates.

The Site workforce will drop from 19,000 to approximately 14,200 by the end of 1995. Further reductions of 1,000 to 3,000 workers are projected over the next two years. This will be followed by a gradual decrease in the workforce over the next five to thirty years.

\subsubsection{Constraints}

A sound infrastructure is essential to the Hanford mission, and future infrastructure needs are tied directly to the mission needs.

Emphasis is placed on providing a streamlined, cost efficient, cost effective infrastructure system to support the Site mission.

Emphasis is placed on seeking opportunities to diversify and/or transition infrastructure systems.

Utility workforce reductions have resulted in the inability to reduce maintenance backlogs in the steam production facilities. The result is that corrective maintenance takes priority over "predictive" types of maintenance. "Predictive" maintenance may not be able to be performed at all.

. Budget baselines will be negatively impacted should personnel reductions not be implemented in a manner that removes the resulting charges to the positions eliminated. 
- Any unusual events such as a major system or component failure, unusual administrative or process upset requirements, or demands above and beyond those described will require additional funding to continue operations.

Funding for infrastructure in FY 1996 is projected to be 30 percent below FY 1994 levels. Funding will continue to fall in the coming years. 
, . 
3.0 Schedule Baseline 



\subsection{SCHEDULE BASELINE}

Table 3-1. Schedule Baseline (WBS 6.8).

\begin{tabular}{|c|c|c|c|c|c|}
\hline $\begin{array}{l}\text { Milestone } \\
\text { Typets? }\end{array}$ & $\begin{array}{l}\text { Control } \\
\text { Nümber }\end{array}$ & Wumber: & (3) & bue date & Apcatedin \\
\hline RL & SSP-96-A01 & 6.8.1.1 & $\begin{array}{l}\text { Develop Plan to Transition to Commercial } \\
\text { Standards }\end{array}$ & $11 / 30 / 95$ & A \\
\hline RL & SSP-96-A02 & 6.8.1.2 & $\begin{array}{l}\text { Develop Plan to Transition } 300 \text { Area Steam to } \\
\text { Commercial Standards }\end{array}$ & $11 / 30 / 95$ & A \\
\hline $\mathrm{RL}$ & SSP-96-A03 & 6.8.1.4 & Submit 20-Year Load Forecast & $12 / 01 / 95$ & A \\
\hline RL & SSP-96-A04 & 6.8.1.4 & Submit 5-Year Electrical Forecast & $12 / 15 / 95$ & A \\
\hline $\mathrm{RL}$ & SSP-96-A05 & 6.8.1.6 & Initiate Contract, Offsite Waste Disposal & $12 / 28 / 95$ & A \\
\hline$R L$ & SSP-96-A06 & 6.8.1.6 & Landfill Closure Plan Submittal & $12 / 31 / 95$ & A \\
\hline RI & SSP-96-A07 & 6.8.1.3 & $\begin{array}{l}\text { Submit 283E Potable Water System Tracer } \\
\text { Study }\end{array}$ & $01 / 05 / 96$ & A \\
\hline RL & SSP-96-A08 & 6.8.1.3 & $\begin{array}{l}\text { Submit } 283 W \text { Potable Water System Tracer } \\
\text { Study }\end{array}$ & $02 / 02 / 96$ & A \\
\hline RL & SSP-96-C01 & 6.8.3.2 & Leased Property Report & $\begin{array}{l}10 / 31 / 95 \\
04 / 29 / 96 \\
\end{array}$ & C \\
\hline RL & SSP-96-E01 & 6.8.5.3 & $\begin{array}{l}\text { Submit annual report describing progress in } \\
\text { achieving EO } 12902 \text { goals. }\end{array}$ & $11 / 30 / 95$ & $\mathbf{E}$ \\
\hline RL & SSP-96-E02 & 6.8.5.1 & $\begin{array}{l}\text { Complete IHEM study EMS-45b, HVAC } \\
\text { Economizer Investigation Phase II }\end{array}$ & $05 / 30 / 96$ & $\dot{\mathrm{E}}$ \\
\hline RL & SSP-96-E03 & 6.8.5.1 & $\begin{array}{l}\text { Complete IHEM study EMS-88a, Energy } \\
\text { Service Contract Company Phase I }\end{array}$ & $05 / 30 / 96$ & $\mathrm{E}$ \\
\hline RL & SSP-96-E04 & 6.8.5.1 & $\begin{array}{l}\text { Complete IHEM study EMS-89, Water } \\
\text { Pumping Efficiency }\end{array}$ & $05 / 30 / 96$ & $E$ \\
\hline $\mathrm{RL}$ & SSP-96-E05 & 6.8.5.1 & $\begin{array}{l}\text { Complete IHEM study EMS-90a, Sitewide } \\
\text { Deactivated Facilities Study Phase I }\end{array}$ & $05 / 30 / 96$ & E \\
\hline RL & SSP-96-E06 & 6.8.5.1 & Complete IHEM study EMS-91a, Fume Hoods & $05 / 30 / 96$ & E \\
\hline $\mathrm{RL}$ & SSP-96-E07 & 6.8 .5 .1 & $\begin{array}{l}\text { Complete IHEM project E-022, } 300 \text { Area } \\
\text { Clearwell Water Pump Drive Improvements }\end{array}$ & $09 / 30 / 96$ & $\mathrm{E}$ \\
\hline RL & SSP-96-E08 & 6.8.5.1 & $\begin{array}{l}\text { Complete IHEM project E-027, Reconfigure } \\
230 \mathrm{kV} \text { Transmission System }\end{array}$ & $09 / 30 / 96$ & E \\
\hline
\end{tabular}

* Refer to Milestone Description Sheets located in Appendices. 
Table 3-1. Schedule Baseline (WBS 6.8).

\begin{tabular}{|c|c|c|c|c|c|}
\hline Mifiestone & Control & NGBS & lin & Bure dite & Apperdix \\
\hline RL & SSP-96-F01 & 6.8.6 & Quarterly Performance Measure Reviews & Quarterly & $\mathbf{F}$ \\
\hline RL & SSP-96-F02 & 6.8.6 & Complete FY 1997 Site Specific Program Plan & 09/30/96 & $\mathbf{F}$ \\
\hline
\end{tabular}

* Refer to Milestone Description Sheets located in Appendices. 


\subsection{Cost Baseline Summary}





\subsection{COST BASELINE SUMMARY}

\subsection{BASIS OF ESTIMATES}

During the summer of 1995, a review was conducted by ICF KH Estimating regarding the Site Support Program Plan cost estimating methodology. The review assessed the supporting cost estimate data against standard cost estimating practices and production guidelines, and provided comments back regarding the basis in relation to the SSPP and outyear planning.

The criteria used for the review included DOE EM-30, Cost and Schedule Estimating Guide, Cost Estimating Manual (DOE/MA-0046); Cost Guide Volume 1-6 (DOE/MA-0063); Budget Formulation (WHC-CM 2-17); Cost Estimating (ICF KH PM 2 Series Procedures).

The activity based cost estimating process includes: the estimate purpose, scope, work breakdown structure (WBS), schedule activities, quantities, assumptions and constraints, governing performances, time and cost, and indirect rates. The review assessed all existing cost data to assure that it met the above criteria, and identified all of the exhibits of cost. Commencing in first quarter FY 1996, these estimates and associated scope/schedule will undergo another review to support a more traditional "bottoms up" estimate for FY 1997 and the out years. This will be an iterative and ongoing process culminating in an overall Infrastructure Program cost, schedule, and scope baseline.

\subsection{MANAGEMENT CONTROL}

A management control system is used by all Infrastructure Program participants for effective planning and control practices, as well as for providing the performance visibility necessary for effective technical, cost, and schedule baseline management. The primary goals are (1) to ensure methods for planning, authorizing, and controlling the work so that it can be completed on schedule and within budget; and (2) ensure that all planning and work performance activities are integrated, technically sound, and in compliance with management and quality requirements. The management control system consists of several subsystems. The major ones are the baseline definition, work authorization, performance measurement, analysis and reporting, and change control. All project planning is developed within the approved WBS.

\subsection{CHANGE CONTROL}

Revisions to the technical, cost, and schedule baseline will be managed in a controlled and disciplined manner. The change control process requires a proposed change be identified, documented, reviewed, approved or disapproved, and that implementation of the change is traceable to the baseline documentation. The primary objectives are to maintain 
accurate baseline descriptions, incorporate baseline changes that maintain clear traceability in a timely and methodical manner, and perform only properly planned and authorized work.

A change request for any baseline element can be requested by any program team member. All requests will be documented on a change request form, which is used to initiate, document, and determine the disposition of proposed changes. The following must be addressed: (1) the technical basis for the change, (2) clear identification of the technical, scope, cost, and schedule/resource impacts, (3) the justification for the change, and the cost, schedule, and technical impacts if the change is not approved, and (4) an indication as to whether the change will affect a Tri-Party Agreement major and/or interim milestone.

Class I changes involve changes to any of the following areas or items, as defined in Management Control System (WHC-CM-2-5):

- The work scope and technical requirements established in the program's site support program plan at the program (level 2) and program element (level 3) levels.

- Change to the program or program element level of the WBS itself.

- The total fiscal year budget as defined in the site support program plan at the program element level.

- The master schedule milestones (TPA, DOE-HQ, and RL controlled milestones) and their milestone descriptions, as defined in the milestone description sheets of the site support program plan.

- Work scope changes that result in requests to RL for incremental funding or revision to current divisional headcount ceilings.

- General and administrative/common support pool rate changes, departmental overhead rates changes, and service pool rates that result in a change to baselines of programs or projects.

\subsection{SUPPORTING INFORMATION}

Backup information is maintained within the program function as support for this program plan. This file contains such things as Building Blocks, Annual Work Plans, and Life Cycle Strategies, if applicable. 


\subsection{Performance Measures}





\subsection{PERFORMANCE MEASURES}

Performance measures for the Infrastructure Programs SSPP will be determined through ICF KH and DOE RL coordination and consensus to ensure the establishment and utilization of the most effective measures. Accordingly, those performance measures depicted in this section are initial in nature and subject to change. Performance measures that display productivity, unit cost of service or product delivered, and managed costs (overhead) will be employed.

Application of additional performance measures for individual SSPP program elements below Level 4 will be the responsibility of the cognizant element manager, but will not be included in the SSPP. These will be tailored as needed to effectively manage the unique nature of each lower-tiered element.

Infrastructure Program performance measurement data will be accumulated, assessed and reported on a monthly basis.

At the end of each FY quarter all performance measures will be jointly reviewed by ICF KH and DOE RL to determine their utility and effectiveness. Ineffective measures will be modified or discontinued and new, more appropriate measures may be added. 

6.0 Appendixes 



\subsection{APPENDIXES}

6.1 APPENDIX A - WBS 6.8.1 [UTILITIES]

6.2 APPENDIX B - WBS 6.8.2 [TRANSPORTATION]

6.3 APPENDIX C - WBS 6.8.3 [GENERAL PURPOSE FACILITIES]

6.4 APPENDIX D - WBS 6.8.4 [SERVICES]

6.5 APPENDIX E - WBS 6.8.5 [ENERGY MANAGEMENT]

6.6 APPENDIX F - WBS 6.8.6 [PROGRAM INTEGRATION] 



\subsection{Appendix A Utilities}





\section{CONTENTS}

6.1 APPENDIX A - UTILITIES [WBS 6.8.1] . . . . . . . . . A-1

6.1 .1 Mission/Vision . . . . . . . . . . . . . . A-1

6.1.1.1 Performance Measures . . . . . . . . . . . A A-1

6.1.2 200 Area Steam [WBS 6.8.1.1] . . . . . . . . . . . A-4

6.1.2.1 Mission/Vision . ................ A-4

6.1.2.2 Goals and Objectives $\ldots \ldots \ldots \ldots \ldots \ldots \ldots$. . . . .

6.1.2.3 Activities Performed . . . . . . . . . . . . A-4

6.1.2.4 Assumptions and Constraints . . . . . . . . . A A-6

6.1.2.5 Regulatory Requirements . . . . . . . . . . . A-7

6.1 .3300 Area Steam $[$ WBS 6.8 .1 .2$] \ldots \ldots \ldots \ldots \ldots \ldots \ldots \ldots . . \ldots$ A-13

6.1.3.1 Mission/Vision ..................... . . .

6.1.3.2 Goals and Objectives $\ldots \ldots \ldots \ldots \ldots \ldots \ldots \ldots$. $\ldots \ldots$

6.1.3.3 Activities Performed . . . . . . . . . . . . . A-13

6.1.3.4 Assumptions and Constraints . . . . . . . . . . . A-15

6.1.3.5 Regulatory Requirements . . . . . . . . . . . . A-17

6.1 .4 Water [WBS 6.8.1.3] . . . . . . . . . . . . . . A-23

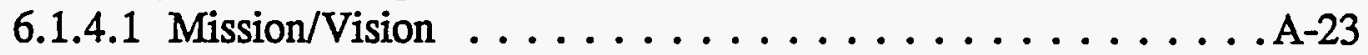

6.1.4.2 Goals and Objectives ................ A-23

6.1.4.3 Activities Performed . . . . . . . . . . . . A-23

6.1.4.4 Assumptions and Constraints . . . . . . . . . A-29

6.1.4.5 Regulatory Requirements . . . . . . . . . . A-30

6.1.5 Electrical Utilities [WBS 6.8.1.4] . . . . . . . . . . A-34

6.1.5.1 Mission/Vision . . . . . . . . . . . . A-34

6.1.5.2 Goals and Objectives . . . . . . . . . . A-34

6.1.5.3 Activities Performed . . . . . . . . . . . . . A-34

6.1.5.4 Assumptions and Constraints . . . . . . . . . . A-37

6.1.5.5 Regulatory Requirements . . . . . . . . . . . A-38

6.1.6 Sanitary Sewers $[$ WBS 6.8.1.5] . . . . . . . . . . . . A-44

6.1.6.1 Mission/Vision . . . . . . . . . . . . . A-44

6.1.6.2 Goals and Objectives ............... A-44

6.1.6.3 Activities Performed . . . . . . . . . . . . . . A-44

6.1.6.4 Assumptions and Constraints . . . . . . . . . . . . A-46

6.1.6.5 Regulatory Requirements . . . . . . . . . . . . . . A-47

6.1.7 Sanitary Solid Waste [WBS 6.8.1.6] . . . . . . . . . . . . A-50

6.1.7.1 Mission/Vision . . . . . . . . . . . . A-50

6.1.7.2 Goals and Objectives . . . . . . . . . . A-50

6.1.7.3 Activities Performed . . . . . . . . . . . . A-50

6.1.7.4 Assumptions and Constraints . . . . . . . . . . A A-51

6.1.7.5 Regulatory Requirements . . . . . . . . . . A-52 


\section{LIST OF TABLES}

A-1 WBS Dictionary $\ldots \ldots \ldots \ldots \ldots \ldots \ldots \ldots \ldots \ldots \ldots$ A $-9 \ldots \ldots$

A-2 Milestone Description Sheet $\ldots \ldots \ldots \ldots \ldots \ldots \ldots \ldots \ldots \ldots \ldots \ldots \ldots \ldots$

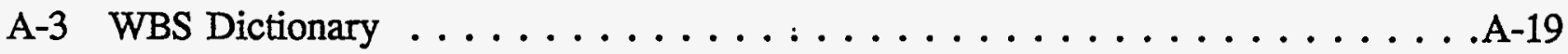

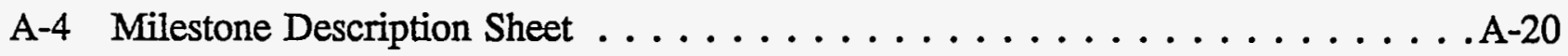

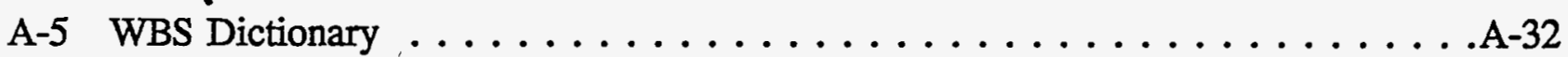

A-6 Milestone Description Sheet $\ldots \ldots \ldots \ldots \ldots \ldots \ldots \ldots \ldots$. . . . . . . . . .

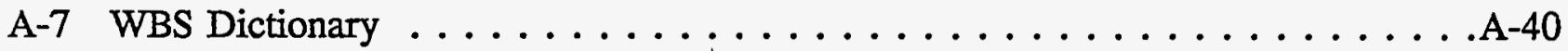

A-8 Milestone Description Sheet $\ldots \ldots \ldots \ldots \ldots \ldots \ldots \ldots \ldots$. . . . . . . . . .

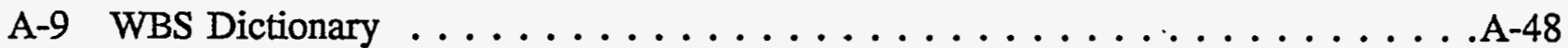

A-10 Milestone Description Sheet . . . . . . . . . . . . . . . . . . . A-49

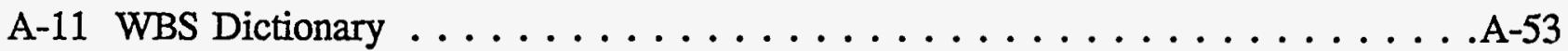

A-12 Milestone Description Sheet . . . . . . . . . . . . . . A-54 


\subsection{APPENDIX A - UTILITIES [WBS 6.8.1]}

\subsubsection{Mission/Vision}

The mission of the Utilities function is to provide utility services by creatively adapting to meet the needs of the Hanford mission. The vision of Utilities is to be valued as a resource that is customer oriented, responsive, cost effective, safe, and highly effective. Goals and objectives that must be achieved to accomplish this mission are:

\subsubsection{Performance Measures.}

1) Objective: Provide low-cost products and required services to our customers.

Goals: (1) Reduce Electrical Utilities unit cost from 5.3 cents/kwh to 5.0 cents/kwh. (2) Reduce the overall costs of water by $10 \%$ before $9 / 30 / 96$. (3) Measure steam unit cost.

Performance Measure: Unit cost performance for 200 Area Steam, 300 Area Steam, Water, and Electrical Utilities.

2) Objective: Meet commitment dates on all internal and external reporting and response requirements.

Goal: Complete $100 \%$ of all identified commitments on a monthly basis.

Performance Measure: Trend the number of completed commitments versus the number of total commitments for the period, based upon the Kaiser Commitment Tracking System.

3) Objective: Comply with applicable sections of DOE Order 5480.19, Conduct of Operations, as identified in the Conduct of Operations applicability matrix approved by RL.

Goal: Achieve an improvement in the Conduct of Operations Event Index.

Performance Measure: Trend the Utilities' Division organization Conduct of Operations Event Index (events per 200,000 man hours). A control chart shall be used to determine the trend and upper/lower control limits for the process. 
4) Objective: Develop an effective Utilities Safety Improvement Plan (SIP) through the involvement of employees for calendar year 1996.

Goal: Complete $100 \%$ of all quarterly reviews to determine each department's performance to their established SIP. Show continuous improvement in safety statistics.

Performance Measure: On a quarterly basis, evaluate each Utility division department's performance to their SIP objectives. Relate safety statistics of the departments to this measure.

5) Objective: Complete customer notifications and reporting time requirements for emergencies, unusual occurrences, and off-normal events as required by DOE Order 5000.3B.

Goal: On a monthly basis, complete $100 \%$ of all customer notifications and reporting time requirements.

Performance Measure: On a monthly basis, trend the number of occurrences that meet the notification and reporting time requirements versus the total number of occurrences for the period.

6) Objective: Effectively manage the work activities within our facilities.

Goal: Achieve an annual Management Effectiveness Indicator (MEI) of 60\%.

Performance Measure: In the Utility Division organization, trend management effectiveness by using the MEI. A control chart shall be used to determine the trend and upper/lower control limits for this process.

7) Objective: Maintain or reduce the percentage of $>90$ day corrective maintenance (CM) work packages.

Goal: Maintain or reduce the percentage of $>90$ day CM work packages. Any decrease is considered an improvement.

Performance Measure: Trend the Utility Division organization number of $>90$ day $\mathrm{CM}$ work packages versus the total number of $\mathrm{CM}$ work packages. This will serve also as an indicator of maintenance budget constraints as discussed under "constraints."

8) Objective: Complete preventive maintenance (PM) work packages within their grace period. 
Goal: Complete $95 \%$ of all PMs within their grace period.

Performance Measure: Trend the number of Utility Division organization PMs completed within the grace period versus the total number of PMs due. A control chart shall be used to determine the trend and upper/lower control limits for the process. This will serve also as an indicator of maintenance budget constraints as discussed under "Constraints." 


\subsubsection{Area Steam [WBS 6.8.1.1]}

6.1.2.1 Mission/Vision. The mission of the 200 Area Steam function is to provide steam services by creatively adapting to meet the needs of the Hanford mission. The function's vision is to be valued as a resource that is customer oriented, responsive, cost efficient, safe, reliable, and highly effective. To help achieve this vision, 200 Area Steam will develop and implement a plan to transition the maintenance and operations functions to commercial standards.

\subsubsection{Goals and Objectives.}

- See section 8.1.1.1, Performance Measures.

- Develop an implementation plan to transition 200 Area Steam operations and maintenance to commercial standards.

6.1.2.3 Activities Performed. The steam function is responsible for generating a reliable source of steam for customers in the 200 Area by operating and maintaining the 284 powerhouse and 200 West package boiler. The 200 Area Steam function is responsible for the operation, administration, maintenance, maintenance support from others, and upgrades to the 284E steam plant, $200 \mathrm{~W}$ package boiler, and related facilities and equipment. The activities performed by 200 Area Steam during FY 1996 are based upon current RL direction that the 284E powerhouse will be operated through the spring of 1996, then prepared for shutdown. The 200 Area Steam function currently consists of:

- Five coal-fired spreader stoker boilers with an operating capacity of 65,000 pounds/hour of steam each, and one oil-fired package boiler that is no longer serviceable.

- One (number 2 diesel) oil-fired package boiler with fuel storage and an operating capacity of 50,000 pounds/hour of steam. This boiler is located adjacent to the $284 \mathrm{~W}$ building. Operation of this boiler is limited to 1,440 total hours per year by its operating permit from the State of Washington.

- Coal handling equipment and facilities for the coal-fired boilers.

- Thirteen miles of steam distribution piping from customer facilities to the steam plant.

- Environmental control equipment and facilities consisting of baghouses, coal ash handling equipment, coal ash storage and disposal equipment, and hazardous waste handling and storage equipment.

- Various facilities and structures to support operations and other support personnel. 
- Services and products provided by others, such as railroad, electrical supply, water supply, craft support from others, telephone, HLAN, mobile equipment maintenance, general purpose facilities, etc.

The total steam generating capacity for the 200 Area Steam function is 375,000 pounds/hour steam, operated at 225 pounds per-square-inch gauge (psig) and 450 degrees fahrenheit. Steam production capability projected for FY 1996, based upon boiler age, available personnel, and budget is 235,000 pounds/hour. Expected steam production to meet customer's needs for FY 1996 will consist of a peak winter production of 235,000 pounds/hour and a minimum summer production of 30,000 pounds/hour.

The following descriptions are tasks that will be completed by the Steam function:

Operations: operation of the steam plant and fuel handling systems, training, management and supervision, project management, operations engineering, safety walkdowns and housekeeping, conduct of operations technical support, administrative support, maintenance coordination, engineering, engineering management, and environmental compliance.

Administration: procedure development, data management, reporting requirements, conduct of operations program management, administrative support, and submittal of quarterly reports regarding the status of corrective action plans for the EM-25 operational assessments of Utilities.

Maintenance: planning and scheduling, maintenance engineering, craft support, corrective maintenance, preventive maintenance, maintenance training, preventive maintenance computer program, material coordination, work control clerk, maintenance management and supervision, administrative support, performance measurement administrator, and turnover of the $284 \mathrm{~W}$ powerhouse to D\&D. The backlog of work for crafts assigned to the 200 Area Steam function averages approximately 4,809 hours per month. Approximately 49 preventive maintenance and calibration work packages; and approximately 82 corrective maintenance, non-corrective maintenance, and modification work packages are worked each month.

Maintenance Support From Others: resources provided by other organizations such as hazardous material support, grounds and equipment maintenance, janitorial, carpenters, painters, sign painters, health physics, landlord maintenance, insulators, program engineering, training, hazardous material operations, solid waste disposal, document control/ release, third-party inspections, quality engineering and quality control, fabrication services, ash pit cleaning, personal protective equipment support, and expense funded projects.

Upgrades/Additions: The following are planned or ongoing upgrade/addition projects scheduled for FY 1996. 
Landlord Program Line Item Construction Projects, WBS 7.5.5:

- L-017, Steam Plant Rehabilitation, Phase II. This project provided a new package boiler for the 200 West Area and will be relocating a new brine system to the 284E powerhouse and replacing deteriorated wood steam line supports.

Expense Funded Projects: Expense funded projects require construction forces in accordance with Davis-Bacon rulings and may include: asbestos encapsulation, removal, and repair; repair of steam lines; repair of building roofs; and the repair or replacement of backflow preventers. The specific scope of these types of projects is typically not well defined because they are often related to unpredicted equipment or system failures. Past history is used to. form a basis for resource requirements.

\subsubsection{Assumptions and Constraints.}

\subsection{Assumptions.}

- Continued operation of the steam function is crucial for the success. of the Hanford Site. Process steam, now provided by the 284E powerhouse is required for processes performed by several programs for which there is no alternative steam source available. In addition, many of the general purpose facility buildings in the 200 Areas require steam for heat. Equipment and systems within the 200 Area Steam facilities were installed nearly 50 years ago and were not designed to meet the requirements and regulations in place today. Current direction from $R L$ indicates that the $284 \mathrm{E}$ powerhouse will be operated through the spring of 1996, then prepared for shutdown when alternate methods for providing steam become available. Continuous operational readiness through FY 96 is assumed in this plan due to absence of firm schedules for alternatives. If the powerhouse is required to operate for more than one additional heating season, improvements/upgrades must be completed so that the risks associated with their operation are within acceptable levels.

- Phasing out steam use by the general purpose facility buildings for building heat and the shutdown of major facilities by other programs will not eliminate the need for a reliable source of steam in the 200 Areas.

- The requested funding will cover normal operating costs. Any unusual events such as a major failure of a system, component, or increases in site assessments, will require additional funding to continue operations.

- The FY 1996 budget assumes that all DOE orders, regulations, and requirements will remain the same throughout the fiscal year. Any changes to these documents will be reviewed and appropriate change requests will be submitted for the revised workscope. 
- Steam requirements in the 200 Areas will go down approximately 50 percent because the old power plants and significant sections of the distribution systems will be shut down. In addition, some facilities using steam for heating will be shut down, while others will be converted from steam to alternative energy sources. Steam requirements will continue to go down as building shutdowns and energy conversions progress over the next several years.

- The Utility Department is required to comply with the conduct of operation 18 chapters (DOE Order 5480.19) as defined by the applicability matrix for the department. The staffing of the department as reflected in this plan assumed that the applicability matrix would be revised to reduce the compliance level of the order. Until the matrix is revised, full compliance cannot be attained as the available staff is not sufficient to fulfill the tasks required for such compliance.

\subsection{Constraints.}

- The backlog of work for crafts assigned to the steam function has remained constant. With the existing workforce, the number of jobs being worked and completed each month remains about the same as the number of new jobs received. This prohibits the maintenance organization from reducing its backlogs to a level where "predictive" types of activities can be performed.

- Individuals funded in "below the line" workscope will continue charging to steam cost accounts until approval is given to eliminate the identified positions. When the approval is given, the remaining funding will be returned to RL through a baseline change request.

6.1.2.5 Regulatory Requirements. The 200 Area Steam function is also required to comply with the following Federal Regulations, State Regulations, and DOE Orders, as noted:

29 CFR 1919, Occupational Safety and Health Standards for General Industry

DOE Order 5480.19, Conduct of Operations

DOE Order 4330.4B, Maintenance Management Program

DOE Order 5000.3B, Occurrence Reporting and Processing of Operations Information

DOE Order 5400.1, (Section 1.4.B) Waste Minimization Efforts to Reduce the Volume and Toxicity of Generated Wastes

29 CFR 1904, Recording and Reporting Occupational Injuries and Illnesses

40 CFR 265, Interim Status Standards for Owner and Operators of Hazardous Treatment Storage, and Disposal Facilities 
WAC 173-303-145/173-303-150, Spills and Discharges Into the Environment

29 CFR 1910.1001/WAC 296-62-077, Asbestos Standards

40 CFR 372.30, EPCRA Reporting Requirements

WAC 173-216, State Waste Discharge Permit Program (Liquid Discharge to the Ground)

WAC 173-218, Underground Injection Control Program

WAC 173-303-350/40 CFR 265.51, Facility Contingency/Emergency Plans

WAC 173-303-200, Record Keeping for 90-Day Accumulation Areas

WAC 173-303-340, Records of Testing and Maintenance of Emergency Equip.

WAC 173-303-360, Building Emergency Responsibilities and Requirements

WAC 173-303-070-110, Dangerous Waste Designation

WAC 173-303-120, General Recycling Requirements

WAC 173-303-140-141, Land Disposal Restrictions

WAC 173-401, Operating Permit Regulation

WAC 173-040, General Standards - Including 20 Percent Opacity, Fugitive Dust, etc.

WAC 173-050, Emission Standards for Combustion and Incineration Units

WAC 173-400-105, Records, Monitoring, and Reporting for Fossil Fuel-Fired Steam Generators 


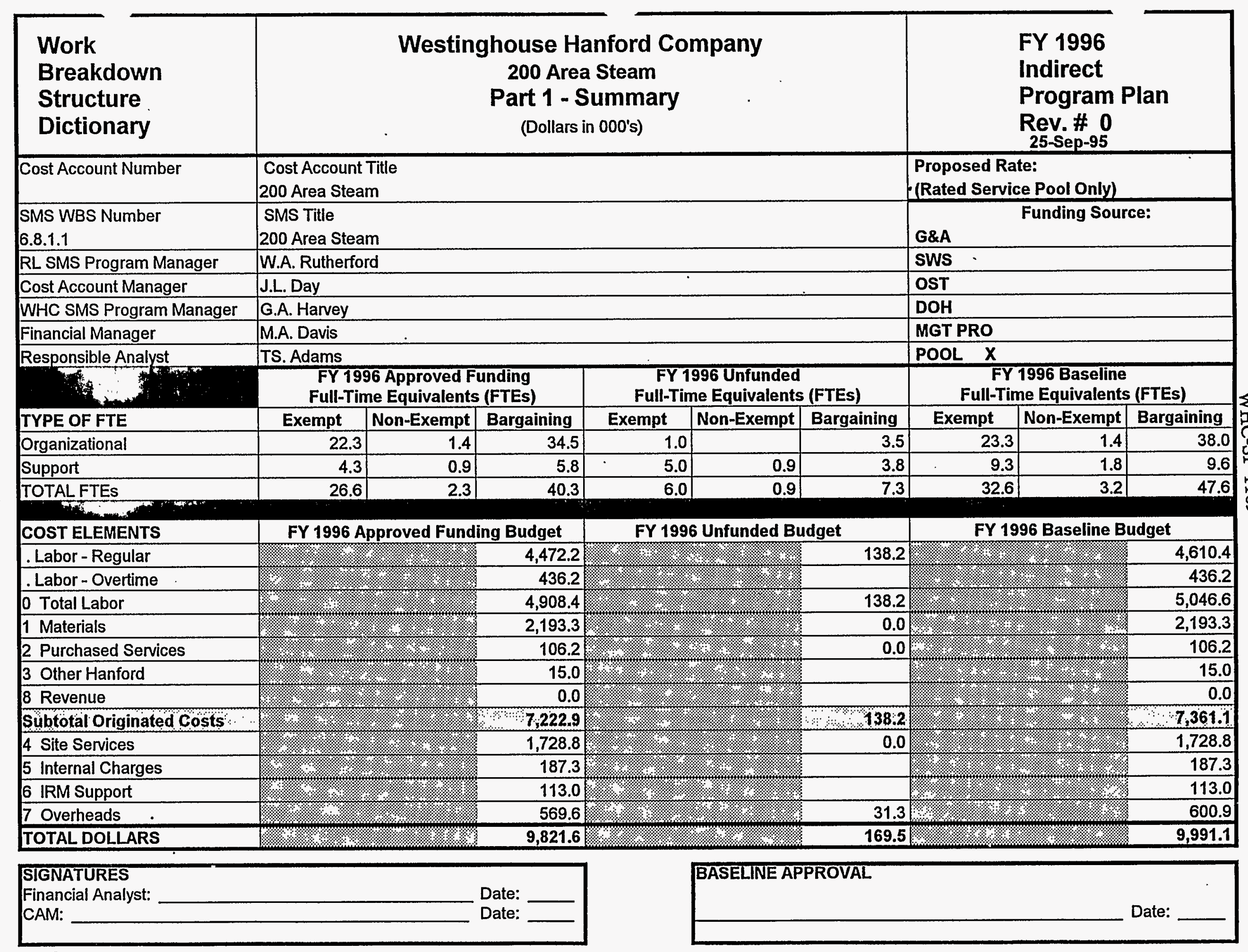


Table A-2. Milestone Description Sheet.

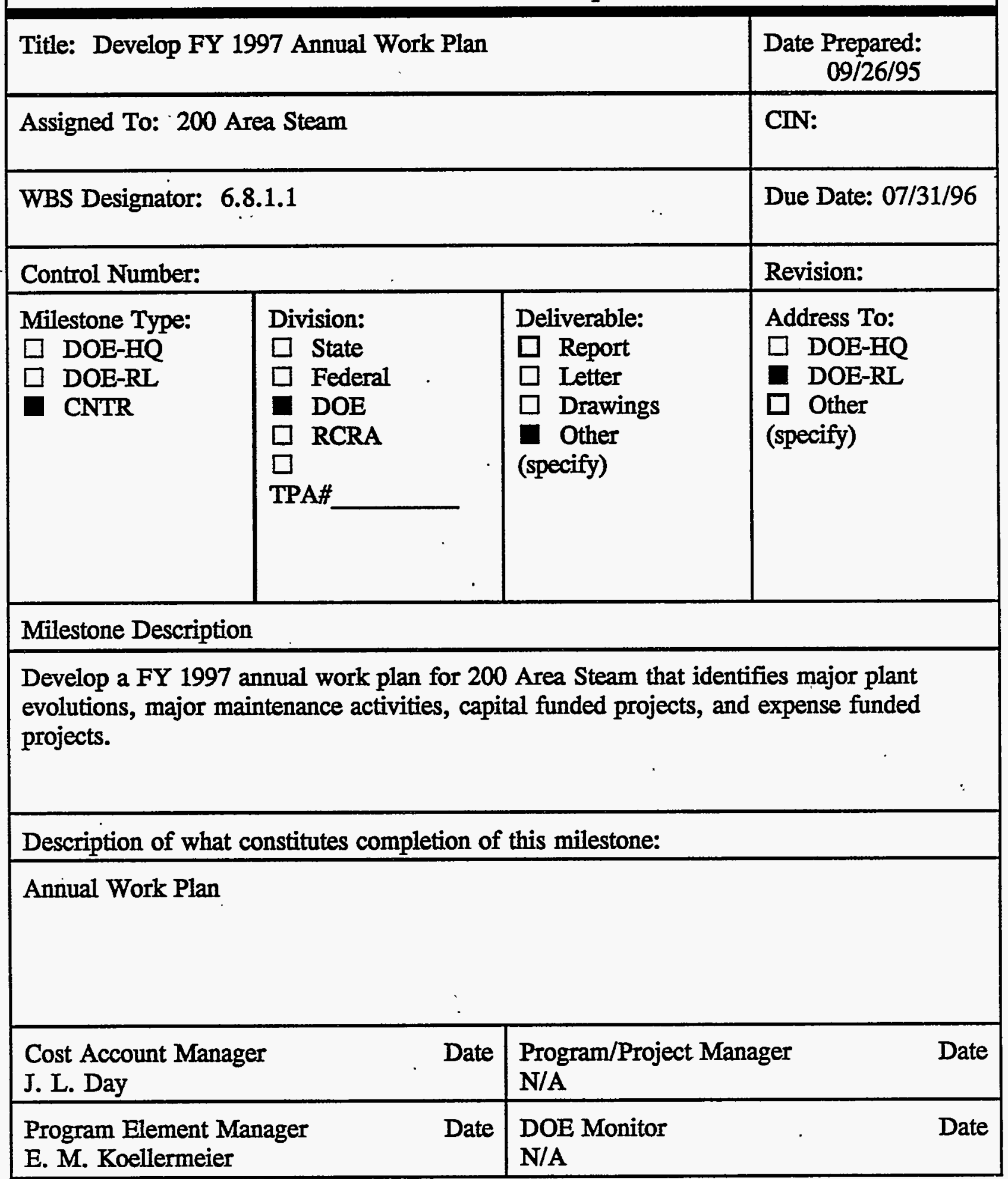


A-2. Milestone Description Sheet.

\begin{tabular}{|c|c|c|c|}
\hline \multicolumn{3}{|c|}{ Title: Develop Plan to Transition to Commercial Standards } & $\begin{array}{r}\text { Date Prepared: } \\
09 / 26 / 95\end{array}$ \\
\hline \multicolumn{3}{|c|}{ Assigned To: 200 Area Steam } & CIN: \\
\hline \multicolumn{3}{|c|}{ WBS Designator: 6.8 .1 .1} & Due Date: $11 / 30 / 95$ \\
\hline \multicolumn{3}{|c|}{ Control Number: SSP-96-A01 } & Revision: \\
\hline $\begin{array}{l}\text { Milestone Type: } \\
\square \text { DOE-HQ } \\
\text { DOE-RL } \\
\square \text { CNTR }\end{array}$ & $\begin{array}{l}\text { Division: } \\
\square \text { State } \\
\square \text { Federal } \\
\text { DOE } \\
\square \text { RCRA } \\
\square \\
\text { TPA\# }\end{array}$ & $\begin{array}{l}\text { Deliverable: } \\
\square \text { Report } \\
\square \text { Letter } \\
\square \text { Drawings } \\
\square \text { Other } \\
\text { (specify) Plan }\end{array}$ & $\begin{array}{l}\text { Address To: } \\
\square \text { DOE-HQ } \\
\square \text { DOE-RI } \\
\square \text { Other } \\
\text { (specify) }\end{array}$ \\
\hline \multicolumn{4}{|c|}{ Milestone Description } \\
\hline \multicolumn{4}{|c|}{$\begin{array}{l}\text { Develop an implementation plan to transition } 200 \text { Area Steam operations and maintenance } \\
\text { to commercial standards. The plan shall identify the commercial standards that will be } \\
\text { used, DOE Orders to be exempted by a pilot project, required changes to existing Utilities } \\
\text { procedures, the method to be used for implementation of the plan, recommended } \\
\text { operations for the pilot, and a schedule for implementation of the plan. }\end{array}$} \\
\hline \multicolumn{4}{|c|}{ Description of what constitutes completion of this milestone: } \\
\hline \multicolumn{4}{|c|}{ Submit Implementation Plan to DOE-RL. } \\
\hline \multicolumn{2}{|c|}{ 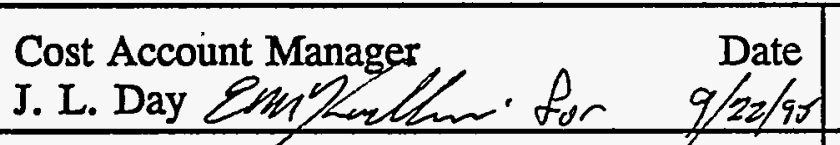 } & \multicolumn{2}{|c|}{$\begin{array}{l}\text { Program/Project } \\
\text { G. A. Harvey } X / 22 / 95\end{array}$} \\
\hline \multicolumn{2}{|c|}{$\begin{array}{l}\text { Program Element Manager } \\
\text { E. M. Koellermeier Em Yhatelom } a / z_{2} / a_{2}\end{array}$} & \multicolumn{2}{|c|}{$\begin{array}{lll}\text { DOE Monitor } & \cdot \\
\text { W. A. Rutherford } & \cdots\end{array}$} \\
\hline
\end{tabular}


Table A-2. Milestone Description Sheet.

\begin{tabular}{|c|c|c|c|}
\hline \multicolumn{3}{|c|}{ Title: Submit 283E Potable Water System Tracer Study } & $\begin{array}{r}\text { Date Prepared: } \\
09 / 26 / 95\end{array}$ \\
\hline \multicolumn{3}{|c|}{ Assigned To: Water } & CIN: \\
\hline \multicolumn{3}{|c|}{ WBS Designator: 6.8 .1 .3} & Due Date: 01/05/96 \\
\hline \multicolumn{3}{|c|}{ Control Number: SSP-95-A07 } & Revision: \\
\hline $\begin{array}{l}\text { Milestone Type: } \\
\square \text { DOE-HQ } \\
\square \text { DOE-RL } \\
\square \text { CNTR }\end{array}$ & $\begin{array}{l}\text { Division: } \\
\square \text { State } \\
\square \text { Federal } \\
\square \text { DOE } \\
\square \text { RCRA } \\
\square \\
\text { TPA\# }\end{array}$ & $\begin{array}{l}\text { Deliverable: } \\
\square \text { Report } \\
\square \text { Letter } \\
\square \text { Drawings } \\
\square \text { Other } \\
\text { (specify) Test Plan }\end{array}$ & $\begin{array}{l}\text { Address To: } \\
\square \text { DOE-HQ } \\
\square \text { DOE-RL } \\
\square \text { Other } \\
\text { (specify) }\end{array}$ \\
\hline
\end{tabular}

Develop a disinfection contact time study plan (200 East Area Tracer Study) and submit to DOE-RL for forwarding to the State Department of Health. The plan and resulting tests are required per WAC 246-290-636.

ICF KH Water Administration will submit to DOE-RL a report on the tracer study test 100 days after receipt of study plan approval by the State Department of Health. An additional milestone will be established reflecting this time duration after State approval.

Description of what constitutes completion of this milestone:

Submittal by cover letter of the study plan to DOE-RL.

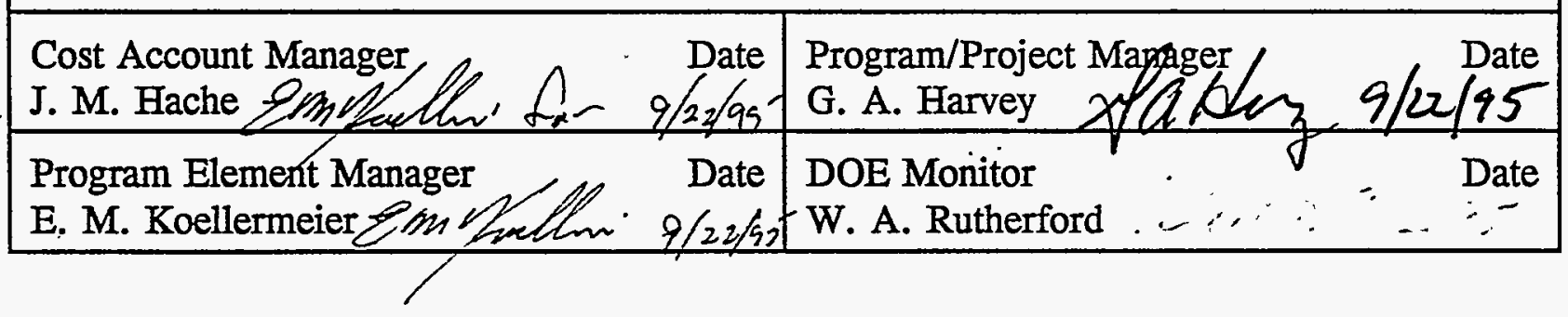




\subsubsection{Area Steam [WBS 6.8.1.2]}

6.1.3.1 Mission/Vision. The mission of the 300 Area Steam function is to provide steam services by creatively adapting to meet the needs of the Hanford mission. The function's vision is to be valued as a resource that is customer oriented, responsive, cost efficient, safe, and highly effective. To help achieve this vision, 300 Area Steam will develop and implement a plan to transition the maintenance and operations functions to commercial standards.

\subsubsection{Goals and Objectives.}

- See Section 6.1.1.1; Performance Measures.

- Develop an implementation plan to transition 300 Area Steam operations and maintenance to commercial standards.

- Determine alternatives for eliminating excess plant air compressor capacity at the 384 Building.

6.1.3.3 Activities Performed. The 300 Area Steam function is responsible for the operation, administration, maintenance, maintenance support from others, and upgrades to the 384 steam plant, 300 Area steam distribution piping, 300 Area condensate return piping, and related facilities and equipment. The 300 Area Steam function also includes a standby electrical power system and compressed utility air generating and distribution system. The activities performed by 300 Area Steam during FY 1996 are based upon current RL direction that the 384 powerhouse will be operated through the spring of 1996, then prepared for shutdown. The 300 Area Steam function currently consists of:

- Three (number 6 bunker) oil-fired boilers; one rated at 80,000 pounds/hour steam, one rated at 100,000 pounds/hour steam, and one rated at 60,000 pounds/hour steam. The stationary boilers are housed in the 384 building and the package boiler is adjacent to the building.

- Fuel oil receiving/storage equipment and facilities. This system contains two 72,000 gallons (each) and two 150,000 gallons (each) bulk storage tanks, and two 16,000 gallons (each) day tanks for storage of number 6 fuel oil.

- Steam distribution piping, valves, and instrumentation from the boilers to different points at the customer facilities.

- Four plant air compressors with a combined capacity of 4,800 cubic feet/minute (cfm) and two portable air compressors with a combined capacity of $1,800 \mathrm{cfm}$ that supply 110 psig of compressed air to the 300 Area. 
- Five standby diesel-driven electrical generators with a combined output of 5,000 kilovolt amperage (kVA) including automatic transfer switching, distribution network, and controls.

- Various facilities and structures to support operations and other support personnel.

- Services and products provided by others, such as electrical supply, water supply, telephone, HLAN, mobile equipment maintenance, general purpose facilities, etc.

The total steam generating capacity for the 300 Area Steam function is 240,000 pounds/hour, operated at $100 \mathrm{psig}$ and 338 degrees fahrenheit. Steam production capability projected for FY 1996, based upon boiler age, available personnel, and budget is 140,000 pounds/hour. Expected steam production to meet customer needs for FY 1996 will consist of a peak winter production of 140,000 pounds/hour, and a minimum summer production of 30,000 pounds/hour.

The 300 Area Steam compressed air system has a total capacity $/$ capability of $6,600 \mathrm{cfm}$ that supplies 110 psig compressed air to the 300 Area; four plant air compressors with a combined output of $4,800 \mathrm{cfm}$, and two portable air compressors with a combined output of $1,800 \mathrm{cfm}$. The customer requirements for compressed air during FY 1996 is expected to be approximately $800 \mathrm{cfm}$. A usable capacity/capability of $5,800 \mathrm{cfm}$ remains in this system.

The 300 Area Steam standby electrical system consists of five standby diesel-driven electrical generators with automatic transfer switching, distribution network, and controls. The total capacity/capability of these generators is 5,000 kVA. The customer's emergency electrical needs range between 2,500 kVA and 3,250 kVA for FY 1996. A usable capacity/ capability of approximately $1,750 \mathrm{kVA}$ to $2,500 \mathrm{kVA}$ remains in this system. function:

The following descriptions are tasks that will be completed by the 300 Area Steam

Operations: operation of the steam plant and fuel handling systems, training, management and supervision, project management, operations engineering, safety walkdowns and housekeeping, conduct of operations technical support, administrative support, maintenance coordination, engineering, engineering management, and environmental compliance.

Administration: procedure development, data management, reporting requirements, conduct of operations program management, administrative support, and submittal of quarterly reports regarding the status of corrective action plans for the EM-25 operational assessments of Utilities.

Maintenance: planning and scheduling, maintenance engineering, craft support, corrective maintenance, preventive maintenance, maintenance training, preventive 
maintenance computer program, material coordination, work control clerk, maintenance management and supervision, administrative support, and performance measurement administrator. The backlog of work for crafts assigned to the 300 Area Steam function averages approximately 4,241 hours per month. Approximately 20 preventive maintenance and calibration work packages; and approximately 85 corrective maintenance, non-corrective maintenance, and modification work packages are worked each month.

Maintenance Support From Others: resources provided by other organizations such as hazardous material support, grounds and equipment maintenance, janitorial, carpenters, painters, sign painters, health physics, landlord maintenance, insulators, program engineering, training, commercial analytical services, hazardous material operations, solid . waste disposal, document control/release, third-party inspections, quality engineering and quality control, fabrication services, personal protective equipment support, electrical utilities maintenance, piping and instrumentation designs, and expense funded projects.

Upgrades/Additions: The following are planned or ongoing upgrade/addition projects scheduled for FY 1996.

Energy Management Program Projects, WBS 6.8.5:

- E-036, 300 Area Package Boiler Economizer. This \$50K project provides a new economizer to the package oil fired boiler to reduce fuel usage. The unit was purchased in FY 95 and will be installed during the first quarter of FY 96.

Landlord Program Capital Equipment Not related to Construction (CENRTC) projects, WBS 7.5.3:

- Fuel-Oil Bunker Heaters Replacement (2F3K2A). This project was funded in FY 1995 and installation will be completed in FY 1996. Due to the length of time the existing heaters have been in service, they will not maintain pressure.

- Standby Generator Exciters (2F3K1B). The existing units will not always work properly and the generators in this facility provide standby power for critical facilities in the 300 Area.

Expense Funded Projects: Expense funded projects require construction forces in accordance with Davis-Bacon rulings and may include: asbestos encapsulation, removal, and repair; repair of steam lines; repair of building roofs; and the repair or replacement of backflow preventers. The specific scope of these types of projects is typically not well defined because. they are often related to unpredicted equipment or system failures. Past history is used to form a basis for resource requirements. 


\subsubsection{Assumptions and Constraints.}

\subsection{Assumptions.}

- The central steam system production and supply configuration of the 300 Area Steam function is essential to its customers and their ability to conduct Hanford mission specific activities. Process steam, now provided by the 384 powerhouse is required for processes performed by several programs for which there is no alternative steam source available. In addition, many of the general purpose facility buildings in the 300 Area require steam for heat. Equipment and systems within 300 Area facilities were installed nearly 50 years ago and were not designed to meet the requirements and regulations in place today. Current direction from RL indicates that the 384 powerhouse will be operated through the spring of 1996, then prepared for shutdown when alternate methods for providing steam become available. Continuous operational readiness through FY 96 is assumed in this plan due to absence of firm schedules for alternatives. If the powerhouses are required to operate for more than one additional heating season, improvements/upgrades must be completed so that the risks associated with their operation are within acceptable levels.

- The Utility Department is required to comply with the conduct of operation 18 chapters (DOE Order 5480.19) as defined by the applicability matrix for the department. The staffing of the department as reflected in this plan assumed that the applicability matrix would be revised to reduce the compliance level of the order. Until the matrix is revised, full compliance cannot be attained as the available staff is not sufficient to fulfill the tasks required for such compliance.

- Phasing out steam use by the general purpose facility buildings for building heat and the shutdown of major facilities by other programs will not eliminate the need for a reliable source of steam in the 300 Area.

- The requested funding will cover normal operating costs. Any unusual events such as a major failure of a system or component, or increases in site assessments, will require additional funding to continue operations.

- The FY 1996 budget assumes that all DOE orders, regulations, and requirements will remain the same throughout the fiscal year. Any changes to these documents will be reviewed and appropriate change requests will be submitted for the revised workscope.

- Steam requirements in the 300 Areas will go down approximately 50 percent because the old power plants and significant sections of the distribution systems will be shut down. In addition, some facilities using steam for heating will be shut down, while others will be converted from steam to alternative energy sources. Steam requirements will continue to go down as building shutdowns and energy conversions progress over the next several years. 


\subsection{Constraints.}

- The backlog of work for crafts assigned to the steam function has remained constant. With the existing workforce, the number of jobs being worked and completed each month remains about the same as the number of new jobs received. This prohibits the maintenance organization from reducing its backlogs to a level where "predictive" types of activities can be performed.

- Individuals funded in "below the line" workscope will continue charging to steam cost accounts until approval is given to eliminate the identified positions. When the approval is given, the remaining funding will be returned to $R L$ through a baseline change request.

6.1.3.5 Regulatory Requirements. The 300 Area Steam function is also required to comply with the following Federal Regulations, State Regulations, and DOE Orders, as noted:

29 CFR 1910, Occupational Safety and Health Standards for General Industry

DOE Order 5480.19, Conduct of Operations

DOE Order 4330.4B, Maintenance Management Program

DOE Order 5000.3B, Occurrence Reporting and Processing of Operations Information

DOE Order 5400.1, (Section 1.4.B) Waste Minimization Efforts to Reduce the Volume and Toxicity of Generated Wastes

29 CFR 1904, Recording and Reporting Occupational Injuries and Illnesses

40 CFR 265, Hazardous Treatment Storage, and Disposal Facilities

WAC 173-303-145/173-303-150, Spills and Discharges Into the Environment

29 CFR 1910.1001/WAC 296-62-077, Asbestos Standards

40 CFR 372.30, EPCRA Reporting Requirements

WAC 173-216, State Waste Discharge Program (Liquid Discharge to the Ground)

WAC 173-218, Underground Injection Control Program

WAC 173-303-350/40 CFR 265.51, Facility Contingency/Emergency Plans

WAC 173-303-200, Record Keeping for 90-Day Accumulation Areas

WAC 173-303-360/340, Bldg. Emergency Responsibilities, Requirements, and Testing 
WAC 173-303-070-110, Dangerous Waste Designation

ẈAC 173-303-120, General Recycling Requirements

WAC 173-303-140-141, Land Disposal Restrictions

WAC 173-401, Operating Permit Regulation

WAC 173-050, Emission Standards for Combustion and Incineration Units

WAC 173-400-105, Records, Monitoring, and Reporting for Fossil Fuel-Fired Steam Generators

WAC 173-303-515, Special Requirements for Used Oil 


\begin{tabular}{|c|c|c|c|c|c|c|c|c|c|}
\hline $\begin{array}{l}\text { Work } \\
\text { Breakdown } \\
\text { Structure } \\
\text { Dictionary }\end{array}$ & \multicolumn{6}{|c|}{$\begin{array}{c}\text { Westinghouse Hanford Company } \\
300 \text { Area Steam } \\
\text { Part } 1 \text { - Summary } \\
\text { (Dollars in 000's) }\end{array}$} & \multicolumn{3}{|c|}{$\begin{array}{l}\text { FY } 1996 \\
\text { Indirect } \\
\text { Program Plan } \\
\text { Rev. \# } 0 \\
25-\text { Sep-95 }\end{array}$} \\
\hline Cost Account Number & \multicolumn{6}{|c|}{$\begin{array}{l}\text { Cost Account Title } \\
300 \text { Area Steam }\end{array}$} & \multicolumn{3}{|c|}{$\begin{array}{l}\text { Proposed Rate: } \\
\text { (Rated Service Pool Only) }\end{array}$} \\
\hline $\begin{array}{l}\text { SMS WBS Number } \\
\text { 6.8.1.2 } \\
\end{array}$ & \multicolumn{6}{|c|}{\begin{tabular}{|l} 
SMS Title \\
300 Area Steam
\end{tabular}} & \multicolumn{3}{|c|}{ Funding Source: } \\
\hline RL SMS Program Manager & \multicolumn{6}{|c|}{ W.A. Rutherford } & \multicolumn{3}{|l|}{ sws } \\
\hline Cost Account Manager & \multicolumn{6}{|l|}{ D.S. Gleason } & \multicolumn{3}{|l|}{ OST } \\
\hline WHC SMS Program Manager & \multicolumn{6}{|l|}{ G.A. Harvey } & \\
\hline Financial Manager & \multicolumn{6}{|l|}{ M.A. Davis } & \multicolumn{3}{|l|}{ MGT PRO } \\
\hline Responsible Analyst & \multicolumn{3}{|c|}{$\begin{array}{l}\text { J.S. Jones } \\
\text { FY } 1996 \text { Approved Funding }\end{array}$} & \multicolumn{3}{|c|}{$\begin{array}{l}\text { FY } 1996 \text { Unfunded } \\
\text { Full-Time Equivalents (FTEs) }\end{array}$} & \multicolumn{3}{|c|}{$\begin{array}{c}\text { FY } 1996 \text { Baseline } \\
\text { Full-Time Equivalents (FTEs) }\end{array}$} \\
\hline TYPE OF FTE & Exempt & Non-Exempt & \begin{tabular}{|l|} 
Bargaining \\
\end{tabular} & Exempt & Non-Exempt & Bargaining & Exempt & \begin{tabular}{|l|} 
Non-Exempt \\
\end{tabular} & \begin{tabular}{|l|} 
Bargaining \\
\end{tabular} \\
\hline Organizational & 16.6 & 2.2 & 22.7 & & & 0.5 & 16.6 & 2.2 & 23.2 \\
\hline Support & 2.8 & 0.0 & 1.9 & 3.6 & 0.8 & & 6.4 & 0.8 & 1.9 \\
\hline TOTALFTES & 19.4 & 2.2 & 24.6 & 3.6 & 0.8 & 0.5 & 23.0 & 3.0 & 25.1 \\
\hline COST ELEMENTS & \multicolumn{3}{|c|}{ FY 1996 Approved Funding Budget } & \multicolumn{3}{|c|}{ FY 1996 Unfunded Budget } & \multicolumn{3}{|c|}{ FY 1996 Baseline Budget } \\
\hline . Labor-Regular & & & $3,089.5$ & & & 48.0 & & & $3,137.5$ \\
\hline . Labor - Overtime & & & 50.0 & & & & & & 50.0 \\
\hline 0 Total Labor & & & $3,139.5$ & & & 48.0 & & & $3,187.5$ \\
\hline 1 Materials & & & 830.0 & & & & & & 830.0 \\
\hline 2 Purchased Services & 8 & & 59.5 & & & & & & 59.5 \\
\hline 3 Other Hanford & . & & 10.0 & & & & & & 10.0 \\
\hline 8 Revenue & & & & & & & & & 0.0 \\
\hline Subtotal originated Costs & & & 4,0390 & & & 18048.0 & & & 4,0870 \\
\hline 4 Site Services & & & $1,062.2$ & & & & & & $1,062.2$ \\
\hline 5 Internal Charges & י & & 210.3 & & & & & & 210.3 \\
\hline 6 IRM Support & & & 97.1 & & & & & & 97.1 \\
\hline 7 Overheads & 7י & : & 291.6 & 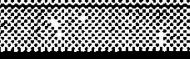 & স & 10.6 & 1) & IV & 302.2 \\
\hline TOTAL DOLLARS & m & - & $5,700.2$ & 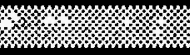 & Im & 58.6 & rm & $-\infty$ & $5,758.8$ \\
\hline $\begin{array}{l}\text { SIGNATURES } \\
\text { Financial Analyst: } \\
\text { CAM: }\end{array}$ & & & $\begin{array}{l}\text { Date: } \\
\text { Date: }\end{array}$ & & BASELINEAF & PROVAL & & & Date: \\
\hline
\end{tabular}


Table A-4. Milestone Description Sheet.

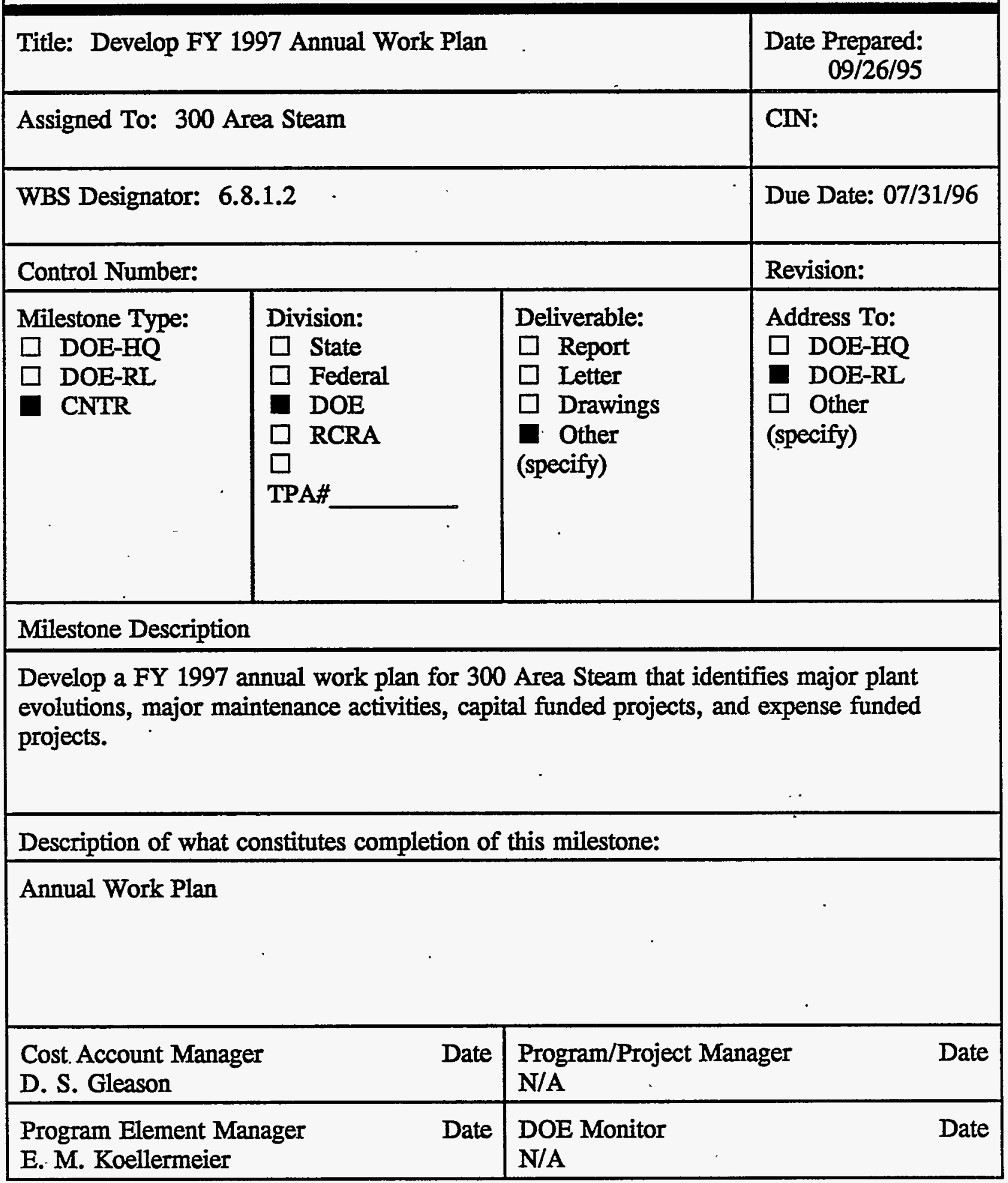


Table A-4. Milestone Description Sheet.

\begin{tabular}{|c|c|c|c|}
\hline \multicolumn{3}{|c|}{$\begin{array}{l}\text { Title: Develop Plan to Transition } 300 \text { Area Steam to Commercial } \\
\text { Standards }\end{array}$} & $\begin{array}{r}\text { Date Prepared: } \\
09 / 26 / 95\end{array}$ \\
\hline \multicolumn{3}{|c|}{ Assigned To: 300 Area Steam } & CIN: \\
\hline \multicolumn{3}{|c|}{ WBS Designator: 6.8 .1 .2} & Due Date: $11 / 30 / 95$ \\
\hline \multicolumn{3}{|c|}{ Control Number: SSP-96-A02 } & Revision: \\
\hline $\begin{array}{l}\text { Milestone Type: } \\
\square \text { DOE-HQ } \\
\square \text { DOE-RL } \\
\square \text { CNTR }\end{array}$ & $\begin{array}{l}\text { Division: } \\
\square \text { State } \\
\square \text { Federal } \\
\square \text { DOE } \\
\square \text { RCRA } \\
\square \\
\text { TPA\# }\end{array}$ & $\begin{array}{l}\text { Deliverable: } \\
\square \text { Report } \\
\square \text { Letter } \\
\square \text { Drawings } \\
\text { Other } \\
\text { (specify) Plan }\end{array}$ & $\begin{array}{l}\text { Address To: } \\
\square \text { DOE-HQ } \\
\square \text { DOE-RL } \\
\square \text { Other } \\
\text { (specify) }\end{array}$ \\
\hline
\end{tabular}

Develop an implementation plan to transition 300 Area Steam operations and maintenance to commercial standards. The plan shall identify the commercial standards that will be used, DOE Orders to be exempted by a pilot project, required changes to existing Utilities procedures, the method to be used for implementation of the plan, recommended operations for the pilot, and a schedule for implementation of the plan.

Description of what constitutes completion of this milestone:

Submit Implementation Plan to DOE-RL.

\begin{tabular}{|c|c|}
\hline $\begin{array}{l}\text { Cost Account Manager } \\
\text { D. S. Gleason Eme }\end{array}$ & $\begin{array}{l}\text { Program/Project } \\
\text { G. A. Harvey }\end{array}$ \\
\hline $\begin{array}{l}\text { Program Element Manager } \\
\text { E. M. Koellermeier Z Mate }\end{array}$ & $\begin{array}{l}\text { DOE Monitor } \\
\text { W. A. Rutherford }\end{array}$ \\
\hline
\end{tabular}


Table A-6. Milestone Description Sheet.

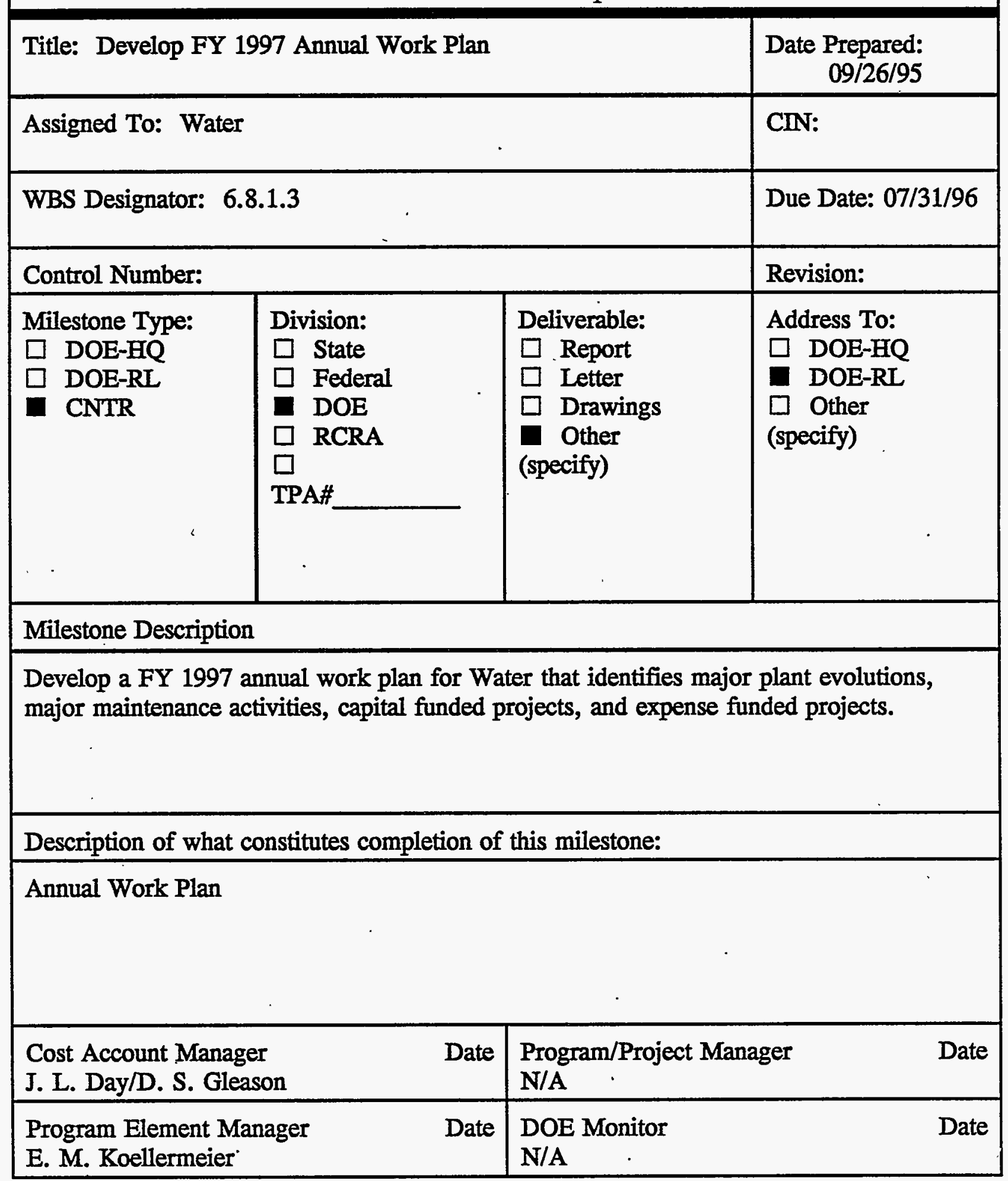




\subsubsection{Water [WBS 6.8.1.3]}

6.1.4.1 Mission/Vision. The mission of the Water function is to provide water services by creatively adapting to meet the needs of the Hanford mission. The function's vision is to be valued as a resource that is customer oriented, responsive, cost efficient, safe, and highly effective.

\subsubsection{Goals and Objectives.}

- See Section 6.1.1.1, Performance Measures.

- Comply with the State of Washington Department of Health Drinking Water Regulations.

6.1.4.3 Activities Performed. The water function is responsible for providing a reliable source of water for customers in the 100,200,300, and 600 Areas by operating and maintaining the 200 Area water system, 300 Area water system, and export water system, up to the service shut-off valve at each facility. The water function consists of five major components; 200 Area Water Service (WBS 6.8.1.3.1), 300 Area Water Service (WBS 6.8.1.3.2), Export Water Service (WBS 6.8.1.3.3), Water Administration (WBS 6.8.1.3.4), and the City of Richland Water Service (WBS 6.8.1.3.9)

The 200 Area Water Service function is responsible for the operation, administration, maintenance, maintenance support from others, and upgrades associated with the water treatment plants, potable water storage tanks, potable water distribution system, and other . related facilities and equipment. The 200 Area Water Service function consists of:

- 283-E Potable Water Treatment Plant with a maximum rated flow of 2,600 gallons-per-minute (gpm).

- 200 East raw water system that includes the 282-E reservoir with a capacity of $3,000,000$ gallons, raw water distribution piping, and 282-E raw water pumphouse. The raw water pumphouse contains three $6,000 \mathrm{gpm}$ electric raw water pumps, one 5,000 gpm electric raw water pump, and one 5,000 gpm steam-driven raw water pump serving the 200 East Area.

- Two clearwells in 200 East, each with a storage capacity of 200,000 gallons of potable water. The pumping capacity/capability from the clearwells to the potable water distribution piping is $4,400 \mathrm{gpm}$; two $1,000 \mathrm{gpm}$ electric pumps, two $600 \mathrm{gpm}$ electric pumps, and two $600 \mathrm{gpm}$ steam pumps.

- 200 East "high tanks" on the water distribution system with a capacity of 200,000 gallons of water. The high tanks also serve to maintain pressure on the system if pumping pressure drops. 
- 283-W Potable Water Treatment Plant with a maximum rated flow of $2,600 \mathrm{gpm}$.

- 200 West raw water system that includes the $282-W$ reservoir with a capacity of $3,000,000$ gallons, raw water distribution piping, and $282-W$ raw water pumphouse. The raw water pumphouse contains one $5,000 \mathrm{gpm}$ electric raw water pump, three $3,000 \mathrm{gpm}$ electric raw water pumps, and one 3,000 gpm steam-driven raw water pump serving the 200 West Area.

- Two clearwells in 200 West, each with a storage capacity of 200,000 gallons of potable water. The pumping capacity/capability from the clearwells to the potable water distribution piping is $5,800 \mathrm{gpm}$; three $1,000 \mathrm{gpm}$ electric pumps, one $600 \mathrm{gpm}$ electric pump, one $1,000 \mathrm{gpm}$ steam pump, and two $600 \mathrm{gpm}$ steam pumps.

- 200 West "high tanks" on the distribution system that contain 200,000 gallons of water. The high tanks also serve to maintain pressure on the system if pumping pressure drops.

- Various facilities and structures to support operations and other support personnel.

- Services and products such as electrical supply, telephone, HLAN, mobile equipment maintenance, general purpose facilities, craft support from others, etc.

The 283-E Potable Water Treatment Plant has a maximum rated flow (capacity/capability) of $2,600 \mathrm{gpm}$. The average monthly potable water flow rate in the 200 East Area ranges between $800 \mathrm{gpm}$ and $875 \mathrm{gpm}$. Daily average flow rates can vary widely depending primarily on area activity. Flow rates as high as $1,200 \mathrm{gpm}$ have been observed during the flushing of lines subsequent to repair or during construction work that affects water usage. Daily flow rates as low as $400 \mathrm{gpm}$ are experienced on days when area activity is minimal. Based upon this fluctuation in water usage, the 283-E plant has an available capacity of between $1,400 \mathrm{gpm}$ and $2,200 \mathrm{gpm}$.

The 283-W Potable Water Treatment Plant has a maximum rated flow (capacity/capability) of $2,600 \mathrm{gpm}$. The monthly average potable water flow rates in the 200 West Area range between $300 \mathrm{gpm}$ and $500 \mathrm{gpm}$. Daily average flow rates in the 200 West Area do not vary quite as much as in the 200 East Area, but ranges of between $250 \mathrm{gpm}$ and $750 \mathrm{gpm}$ have been observed. Based upon this fluctuation in water usage, the 283-W plant has an available capacity of between 1,850 gpm and 2,350 gpm.

The capacity of the current water storage and supply systems within 200 Area Water Service do not meet National Fire Protection Association (NFPA) standards. Project B-604, Water System Upgrades- Reservoir, will provide new facilities and upgrades to existing facilities in 200 East and 200 West to provide a second water system for both raw water and sanitary water and comply with NFPA requirements. 
The 300 Area Water Service is responsible for the operation, administration, maintenance, maintenance support from others, and upgrades associated with the Columbia River water pumphouse, water treatment plant, treated water storage tanks, and other related facilities and equipment. The budget for sanitary sewer service in the 300 Area is included within the 300 Area Water Service due to methods used to allocate charges. See Sanitary Sewers, WBS 6.8.1.5, for further description. The 300 Area Water Service function consists of:

- 315 Potable Water Treatment Plant has a maximum rated flow (capacity/ capability) of 3,200 gpm of potable water. The plant is designed to filter and chlorinate the raw water for potable uses, fire protection, and various process needs.

- 312 River Water Pumphouse contains two motor-driven vertical turbine pumps and one smaller emergency (biology) pump. The biology pump is a motordriven vertical turbine pump that is activated at low header pressure. It is designed to provide emergency raw water to the fish study facility. The two primary pumps are operated alternately at one-week intervals. Each of the two river water pumps is rated at $10,000 \mathrm{gpm}$. The average demand is roughly $20 \%$ of the design flow capacity.

- 300 Area water distribution system that consists of one 800,000 gallon water reservoir, one 900,000 gallon water reservoir, the 382-B pumphouse, and the 382 pumphouse. The 382-B pumphouse contains two 3,000 gpm diesel-driven booster pumps. The 382 pumphouse contains five electric pumps; two 1,600 gpm pumps, one 1,050 gpm pump, one 4,000 gpm pump, and one $1,500 \mathrm{gpm}$ pump.

- Two clearwell pumps supply filtered water to the 300 Area. Each is rated at $4,000 \mathrm{gpm}$. The filtered water is stored in three tanks having a total capacity of $1,325,000$ gallons.

- A 70,000 gallon clearwell holds filtered water. Additional chlorination takes place at the clearwell inlet to maintain an adequate chlorine residual throughout the 300 Area.

- Services and products such as electrical supply, telephone, HLAN, mobile equipment maintenance, general purpose facilities, craft support from others, etc.

The 315 water treatment plant has a capacity/capability of $3,200 \mathrm{gpm}$ of potable water. Monthly average flow for customers in the 300 Area ranges between $1,000 \mathrm{gpm}$ and $1,450 \mathrm{gpm}$. An average reduction of $500 \mathrm{gpm}$ is expected due to the decrease of activity in the area. This should give the water treatment plant an available capacity of between $2,250 \mathrm{gpm}$ and $2,700 \mathrm{gpm}$. 
The 382-B pumphouse with two 3,000 gpm diesel-driven pumps, and the 800,000 gallon water reservoir were installed by project $L-001$ to upgrade the water distribution system in the 300 Area and bring it into compliance with NFPA requirements.

The Export Water Service function is responsible for the operation, administration, maintenance, maintenance support from others, and upgrades associated with the 100-B river pumphouse, 182-B reservoir, 182-B raw water pumphouse, 100-D river pumphouse, 182-D reservoir, and other related facilities and equipment. The Export Water Service function currently consists of:

- 100-B Area River Pumphouse that contains six 10,500 gpm electric pumps and one 7,500 gpm diesel pump. The total capacity of this system is 70;500 gpm.

- 182-B Reservoir with a capacity of $25,000,000$ gallons.

- 182-B Raw Water Pumphouse that contains five 6,000 gpm electric pumps, one 3,000 gpm electric pump, and four 3,000 gpm diesel pumps. The total capacity of this system is $45,000 \mathrm{gpm}$.

- 100-D Pumphouse that contains four 13,500 gpm electric pumps. The total capacity of this system is $54,000 \mathrm{gpm}$.

- 182-D Reservoir with a capacity of $25,000,000$ gallons.

- Approximately 25 miles of distribution piping that ranges in size from 24 inches to 42 inches.

- Various facilities and structures to support operations and other support personnel.

- Services and products provided by others, such as electrical supply, telephone, HLAN, mobile equipment maintenance, craft support from others, general purpose facilities, etc.

The 100-B Pumping Plant has the capability for pumping 45,000 gpm of raw water from the 182-B reservoir into the raw water system. The 100-D backup pumping plant can supply $54,000 \mathrm{gpm}$ of water into the raw water system. Daily pumping averages for the plant are at 19,000,000 gallons. The export water system capacity is expected to meet customer needs for the foreseeable future.

The ICF KH Utilities organization is accountable for the Water Purveyor responsibilities and drinking water monitoring programs (including administration and sampling in accordance with State Drinking Water regulations) at the Hanford Site, and has enforcement authority for the cross connection control program in the 200 and 300 Areas. These responsibilities are managed by the Water Administration function. The Water Administration function also completes required sampling, recording, reporting, and 
recommends modifications needed to ensure sitewide compliance with applicable drinking water regulations. This workscope includes the implementation of corrective actions for any drinking water deficiencies found at the Hanford Site, with the exception of $100 \mathrm{~K}$ and $100 \mathrm{~N}$ Areas.

Within the $100 \mathrm{~K}$ and $100 \mathrm{~N}$ Areas, the Water Administration function is responsible for technical support and administrative overview. When requested and funded by organizations in the $100 \mathrm{~K}$ and $100 \mathrm{~N}$ Areas, this function will also perform water monitoring, provide sampling services, and act as the interface with the Department of Health.

The City of Richland Water Service function provides an alternate potable water source to the $\mathbf{3 0 0}$ Area. This service is provided by the City of Richland at a predetermined price based upon actual usage. Potable water is obtained from the City of Richland via an existing 16 inch import line, from the City to the 300 Area, for meeting customer needs during emergency situations or during maintenance outages. The existing rate structure with the City of Richland requires a monthly fee of $\$ 225$ for the first 500 cubic-feet of water usage, then 57 cents per 100 cubic-feet of water usage thereafter.

The following descriptions are tasks that will be completed by the Water function:

Operations: plant operations, training, chlorine serviceman, operations management and supervision, engineering, operations engineering, project management, administrative support, safety walkdowns and housekeeping, maintenance coordination, engineering manager, environmental compliance, and conduct of operations technical support.

Administration: procedure development, data management, reporting requirements, conduct of operations program management, administrative support, and submittal of quarterly reports regarding the status of corrective action plans for the EM-25 operational assessments of Utilities.

Maintenance: planning and scheduling, maintenance engineering, craft support, corrective maintenance, preventive maintenance, maintenance training, preventive maintenance computer program, material coordination, work control clerk, maintenance management and supervision, administrative support, and performance measurement administrator. The backlog of work for crafts assigned to the Water function averages approximately 4,506 hours per month. Approximately 38 preventive and calibration work packages; and approximately 74 corrective maintenance, non-corrective maintenance, design, and modification work packages are worked each month.

Maintenance Support From Others: resources provided by other organizations such as hazardous material support, grounds and equipment maintenance, janitorial, carpenters, painters, sign painters, health physics, program engineering, training, commercial analytical services, hazardous materials operations, solid waste disposal, document control and release, third-party inspections, quality engineering and quality control, diesel mechanics, personal protective equipment support, fabrication services, electrical utilities maintenance, and expense funded projects. 
Water Administration: cross-connection control specialist, water distribution manager, procedure development, sampling, and the development of inorganic, organic, and. radionuclides monitoring plans.

Upgrades/Additions: The following are planned or ongoing upgrade/addition projects scheduled for FY 1996.

Landlord Program Line Item Construction Projects, WBS 7.5.5:

- B-604, Water System Upgrades- Reservoir, scheduled for completion 11/97. The 200 Area water system does not comply with fire protection requirements of NFPA. This project will begin construction in FY 1996 to provide redundant water supplies for fire protection requirements of 200 East and 200 West buildings and facilities.

Landlord Program Capital Equipment Not Related to Construction (CENRTC), WBS 7.5.3:

- River Screen Replacement (2F3N5C), 181B and 181D River Pumphouses. The installation will be completed in FY 1996. The project is required due to the failure of existing screens and to comply with environmental protection requirements for fish.

- Potable Water Pump and Control Replacements (2F3K0A), 283E and 283W. The installation will be completed in FY 1996. This project provides modern and more efficient pumps.

- Sanitary Water Pump Replacements (2F3K1A), 382 Building. Additional funding in FY 1996 is required to provide and install the pumps. Design was completed with available funds in FY 1995. This project replaces obsolete and failing booster pumps for the 300 Area water system.

Energy Management Program Projects, WBS 6.8.5:

- E-022, 300 Area Sanitary and Raw Water System Upgrade. This energy savings project provides new and smaller river pumps/controls at the 312 facility and new pumps/controls at the 315 water treatment plant. The project will significantly reduce energy requirements for pumping water to the 300 Area. Actual savings will be determined and factored into the water function budget after the project is completed.

Expense Funded Projects: Expense funded projects require construction forces in accordance with Davis-Bacon rulings and may include: repair of potable water lines; repair of raw water lines; repair of building roofs; repair of reservoir fencing; painting of facilities; and the repair or replacement of backflow preventers. The specific scope of these types of projects is typically not well defined because they are often related to unpredicted equipment or system failures. Past history is used to form a basis for resource requirements. 


\subsubsection{Assumptions and Constraints.}

\subsection{Assumptions.}

The 200 Area Water Service, 300 Area Water Service, Export Water Service, Water Administration, and the City of Richland Water Service functions are essential to their customer's ability to conduct Hanford Specific activities.

- The FY 1996 budget assumes that all DOE orders, regulations, and requirements will remain the same throughout the fiscal year. Any changes to these documents will be reviewed and appropriate change requests submitted for the revised workscope.

- Water consumption on Site is far below capacity and declining further in FY 1996. All water requirements are expected to go down except for irrigation and perhaps fish rearing and fish study needs.

- The Utility Department is required to comply with the conduct of operation 18 chapters (DOE Order 5480.19) as defined by the applicability matrix for the department. The staffing of the department as reflected in this plan assumed that the applicability matrix would be revised to reduce the compliance level of the order. Until the matrix is revised, full compliance cannot be attained as the available staff is not sufficient to fulfill the tasks required for such compliance.

\subsection{Constraints.}

- The backlog of work for crafts assigned to the water functions remains constant. With the existing workforce, the number of jobs being worked and completed each month remains about the same as the number of new jobs received. This prohibits the maintenance organization from reducing its backlogs to a level where "predictive" types of activities can be performed.

- The requested funding will cover normal operating costs. Any unusual events such as a major failure of a system or component, or increases in site assessments, will require additional funding to continue operations.

- Individuals funded in "below the line" workscope will continue charging to water cost accounts until approval is given to eliminate the identified positions. When the approval is given, the remaining funding will be returned to $R L$ through a baseline change request.

- New facility projects and activities planned for the 200 East Area will increase both the demand and consumption of potable water in that area. The extent of the increase is wholly dependent upon the size, scope, and ultimately the approval of these projects. During the same time frame some facilities will be removed or cease operation. The reduction of demand and consumption brought 
about by either removal of facilities or cessation of activities is contingent upon funding approval and evolving program plans. It is currently assumed that the existing potable water system will meet future demand and consumption requirements. All future projects are subject to rigorous review, years in advance of actual construction, with regard to impact on existing utilities and services. If any demand on the utilities cannot be met by existing services, the benefiting program/project is required to fund the necessary additional capacity.

- Drinking water monitoring is only performed at the $100 \mathrm{~K}$ and $100 \mathrm{~N}$ Areas if funding is provided by the organizations responsible for these areas.

6.1.4.5 Regulatory Requirements. The Water function is also required to comply with the following Federal Regulations, State Regulations, and DOE Orders, as noted:

29 CFR 1910, Occupational Safety and Health Standards for General Industry

DOE Order 5480.19, Conduct of Operations

DOE Order 4330.4B, Maintenance Management Program, Chapter I

DOE Order 5000.3B, Occurrence Reporting

DOE Order 5400.1, (Section 1.4.B) Waste Minimization Efforts to Reduce the Volume and Toxicity of Generated Wastes

29 CFR 1904.1-.22, Recording/Reporting Occupational Injuries and Illnesses

40 CFR 265.194, Basic RCRA Operating Requirements

40 CFR 265.196, RCRA Waste Removal Regulations

29 CFR 1910.1001/WAC 296-62-077, Asbestos Standards

40 CFR 372.30, EPCRA Reporting Requirements

DOE Order 5480.7, Fire Protection

NFPA 13, 1989, Installation of Sprinkler Systems

NFPA 24, 1987, Installation of Private Fire Service Mains

Public Law 99-523, The Federal Safe Drinking Water Act of 1974

Public Law 99-339, The Federal Safe Drinking Water Act Amendments of 1986

WAC 246-290 Group A, Public Water Systems 
WAC 246-291 Group B, Public Water Systems

WAC 246-292, Water Works Operator Certification

WAC 173-216, State Waste Discharge Permit Program (Liquid Discharge to the Ground)

WAC 173-218, Underground Injection Control Program

WAC 173-303-350/40 CFR 265.51, Facility Contingency/Emergency Plans

WAC 173-303-200, Record Keeping for 90-Day Accumulation Areas

WAC 173-303-340, Records of Testing and Maintenance of Emergency Equip.

WAC 173-303-360, Building Emergency Responsibilities and Requirements

WAC 173-303-070-110, Dangerous Waste Designation

WAC 173-303-120, General Recycling Requirements

WAC 173-303-140-141, Land Disposal Restrictions

WAC 173-303-145/173-303-150, Spills and Discharges Into the Environment

Hanford Federal Facility and Consent Order 


\begin{tabular}{|c|c|c|c|c|c|c|c|c|c|}
\hline $\begin{array}{l}\text { Work } \\
\text { Breakdown } \\
\text { Structure } \\
\text { Dictionary }\end{array}$ & \multicolumn{6}{|c|}{$\begin{array}{l}\text { Westinghouse Hanford Company } \\
\text { Water Utility Summary } \\
\text { Part } 1 \text { - Summary } \\
\text { (Dollars in 000's) }\end{array}$} & \multicolumn{3}{|c|}{$\begin{array}{l}\text { FY } 1996 \\
\text { Indirect } \\
\text { Program Plan } \\
\text { Rev. \# } 0 \\
25-\text { Sep-95 }\end{array}$} \\
\hline Cost Account Number & \multicolumn{6}{|c|}{$\begin{array}{l}\text { Cost Account Title } \\
\text { Water Utility Summary }\end{array}$} & \multicolumn{3}{|c|}{$\begin{array}{l}\text { Proposed Rate: } \\
\text { (Rated Service Pool Only) }\end{array}$} \\
\hline $\begin{array}{l}\text { SMS WBS Number } \\
\text { 6.8.1.3 }\end{array}$ & \multicolumn{6}{|c|}{\begin{tabular}{|l|} 
SMS Title \\
Water Utility Summary
\end{tabular}} & \multicolumn{3}{|c|}{ Funding Source: } \\
\hline RL SMS Program Manager & & \multicolumn{3}{|l|}{ SWS } \\
\hline Cost Account Manager & & & & \multicolumn{3}{|c|}{ W.A. Rutherford } & \multicolumn{3}{|l|}{ OST } \\
\hline WHC SMS Program Manager & \multicolumn{6}{|l|}{ G.A. Hanvey } & \\
\hline Financial Manager & \multicolumn{6}{|l|}{ M.A. Davis } & & \multicolumn{2}{|c|}{$\frac{\text { MGT PRO }}{\mathrm{POO}} \mathrm{x}$} \\
\hline Responsible Analyst & \multicolumn{3}{|c|}{$\begin{array}{c}\text { FY } 1996 \text { Approved Funding } \\
\text { Full-Time Equivalents (FTEs) }\end{array}$} & \multicolumn{3}{|c|}{$\begin{array}{l}\text { FY 1996 Unfunded } \\
\text { Full-Time Equivalents (FTEs) }\end{array}$} & \multicolumn{3}{|c|}{\begin{tabular}{|c|} 
POOL $X$ \\
FY 1996 Baseline \\
Full-Time Equivalents (FTEs)
\end{tabular}} \\
\hline TYPE OF FTE & Exempt & Non-Exempt & \begin{tabular}{|l|} 
Bargaining \\
\end{tabular} & Exempt & \begin{tabular}{|l|} 
Non-Exempt \\
\end{tabular} & Bargaining & Exempt & Non-Exempt & Bargaining \\
\hline Organizational & 27.8 & 2.4 & 35.1 & & & & 27.8 & 2.4 & 35.1 \\
\hline Support & 3.6 & 0.5 & 2.4 & 2.6 & 0.5 & & 6.2 & 1.0 & 2.4 \\
\hline TOTALFTES & 31.4 & 2.9 & 37.5 & 2.6 & 0.5 & 0.0 & 34.0 & 3.4 & 37.5 \\
\hline COST ELEMENTS & \multicolumn{3}{|c|}{ FY 1996 Approved Funding Budget } & \multicolumn{3}{|c|}{ FY 1996 Unfunded Budget } & \multicolumn{3}{|c|}{ FY 1996 Baseline Budget } \\
\hline Labor-Regular & 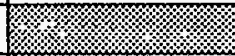 & & $4,587.8$ & & $x_{2}$ & 57.7 & צי & & $4,645.5$ \\
\hline . Labor - Overtime & "थ= & & 220.1 & & & & & & 220.1 \\
\hline 0 Total Labor & 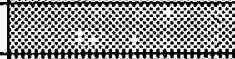 & & $4,807.9$ & & & 57.7 & & & $4,865.6$ \\
\hline 1 Materials & & & 290.4 & & & & & & 290.4 \\
\hline 2 Purchased Services & & & 236.6 & & & & & & 236.6 \\
\hline 3 Other Hanford & & & 119.0 & & & & & & 119.0 \\
\hline 8 Revenue & & & & & & & & & 0.0 \\
\hline Subtotal Originated Costs & & & 545339 & & & .57 & & & $.5,5116$ \\
\hline 4 Site Services & 1 & & $1,476.7$ & & & & & & $1,476.7$ \\
\hline 5 Internal Charges & m & & 704.9 & & & & & & 704.9 \\
\hline 6 IRM Support & $\because \because \because \because \because$ & & 149.4 & & & & & & .149 .4 \\
\hline 7 Overheads & \# & 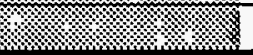 & 406.6 & & & 8.5 & (n) & X & 415.1 \\
\hline TOTAL DOLLARS & 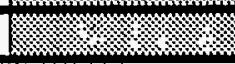 & m-min & $8,191.5$ & 28 & (m) & 66.2 & 1 & 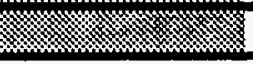 & $8,257.7$ \\
\hline $\begin{array}{l}\text { SIGNATURES } \\
\text { Financial Analyst: } \\
\text { CAM: }\end{array}$ & 工 & - & $\begin{array}{l}\text { Date: } \\
\text { Date: }\end{array}$ & & BASELINEAP & PROVAL & & & Tate: \\
\hline
\end{tabular}


Table A-6. Milestone Description Sheet.

\begin{tabular}{|c|c|c|c|}
\hline \multicolumn{3}{|c|}{ Title: Develop FY 1997 Annual Work Plan } & $\begin{array}{r}\text { Date Prepared: } \\
09 / 26 / 95\end{array}$ \\
\hline \multicolumn{3}{|c|}{ Assigned To: Water } & CIN: \\
\hline \multicolumn{3}{|c|}{ WBS Designator: 6.8 .1 .3} & Due Date: $07 / 31 / 96$ \\
\hline \multicolumn{3}{|l|}{ Control Number: } & Revision: \\
\hline $\begin{array}{l}\text { Milestone Type: } \\
\square \text { DOE-HQ } \\
\square \text { DOE-RL } \\
\text { CNTR }\end{array}$ & $\begin{array}{l}\text { Division: } \\
\square \text { State } \\
\square \text { Federal } \\
\square \text { DOE } \\
\square \text { RCRA } \\
\square \\
\text { TPA\# }\end{array}$ & $\begin{array}{l}\text { Deliverable: } \\
\square \text { Report } \\
\square \text { Letter } \\
\square \text { Drawings } \\
\square \text { Other } \\
\text { (specify) }\end{array}$ & $\begin{array}{l}\text { Address To: } \\
\square \text { DOE-HQ } \\
\square \text { DOE-RL } \\
\square \text { Other } \\
\text { (specify) }\end{array}$ \\
\hline \multicolumn{4}{|c|}{ Milestone Description } \\
\hline \multicolumn{4}{|c|}{$\begin{array}{l}\text { Develop a FY } 1997 \text { annual work plan for Water that identifies major plant evolutions, } \\
\text { major maintenance activities, capital funded projects, and expense funded projects. }\end{array}$} \\
\hline \multicolumn{4}{|c|}{ Description of what constitutes completion of this milestone: } \\
\hline \multicolumn{4}{|l|}{ Annual Work Plan } \\
\hline \multicolumn{2}{|c|}{$\begin{array}{l}\text { Cost Account Manager } \\
\text { J. L. Day/D. S. Gleason }\end{array}$} & \multicolumn{2}{|c|}{$\begin{array}{l}\text { Program/Project Manager } \\
\text { N/A }\end{array}$} \\
\hline \multicolumn{2}{|c|}{$\begin{array}{l}\text { Program Element Manager } \quad \text { Date } \\
\text { E. M. Koellermeier }\end{array}$} & \multicolumn{2}{|c|}{$\begin{array}{l}\text { DOE Monitor } \quad \text { Date } \\
\text { N/A }\end{array}$} \\
\hline
\end{tabular}




\subsubsection{Electrical Utilities [WBS 6.8.1.4]}

6.1.5.1 Mission/Vision. The mission of the Electrical Utilities function is to provide electrical related services by creatively adapting to meet the needs of the Hanford Mission. The function's vision is to be valued as a resource that is customer oriented, responsive, cost efficient, safe, and highly effective.

\subsubsection{Goals and Objectives. See section 6.1.1.1, Performance Measures.}

\subsubsection{Activities Performed. Electrical Utilities is responsible for the Hanford electrical} transmission and distribution system. This function operates and maintains the 100/200 Area and 300 Area electrical systems, provides sitewide PCB oil-leak cleanup and waste management services, and provides maintenance support for the 400 Area electrical system, currently operated by FFTF operations and engineering. Electrical power for the 700, 1100, and 3000 Areas is provided by the City of Richland. The Electrical Utilities function works with both the Bonneville Power Administration (BPA) and the City of Richland to ensure that forecasted electrical needs for the Hanford Site are met.

Electrical Utilities is responsible for the operation, administration, maintenance, maintenance support from others, and upgrades associated with the 100/200 Area electrical system, 300 Area electrical system, 251W substation, and other related facilities and equipment. The Electrical Utilities function consists of:

- $100 / 200$ Areas electrical system with approximately 50 miles of $230 \mathrm{kV}$ transmission lines with six primary substations, 135 miles of $13.8 \mathrm{kV}$ distribution lines with 124 secondary substations, and 595 transmission and distribution relays.

- 300 Area electrical system with approximately 20 miles of $13.8 \mathrm{kV}$ distribution lines with four substations, 306 transmission and distribution relays, and two miles of $2.4 \mathrm{kV}$ distribution lines.

- $251 \mathrm{~W}$ substation that serves as the electrical dispatch center for the Hanford Site and houses the Supervisory, Control, and Data Acquisition (SCADA) system. The substation allows the dispatcher to change electrical routings remotely through seven primary substations (six in 100/200 Areas and one in 300 Area) and six secondary substations (one in 200E, one in 200W, and four in 300 Area). As requested by customers and programs, the $251 \mathrm{~W}$ substation is operated on a 24-hour (7 days-per-week) basis to maintain continuous electrical coverage at the Hanford Site. This "around-the-clock" operation of the substation requires the use of approximately 8 FTEs.

- Various facilities and structures to support operations and other support personnel. 
- PCB Oil-leak cleanup and waste management services. This activity is expected dispose of approximately 150,000 to 200,000 pounds of PCB waste material, plus 9 transformers (from FFTF) during FY 1996.

- Direct funded services related to Electrical Utilities such as FFTF maintenance, lineman and electrician standby support, rubber goods testing, special outages, etc. The cost of providing these services during FY 1996 will be approximately $\$ 237,000$ (4 FTEs @ \$59,250 each), including overhead. The cost and FTEs associated with these activities are funded directly by customers and programs, and not included within the budget for this program plan.

- Services and products provided by others, such as water supply, training, asbestos/hazardous waste support, telephone, HLAN, mobile equipment maintenance, general purpose facilities, craft support from others, etc.

The 100/200 Area electrical system has six primary substations with a usable capacity of 195 megawatts (MW). The system has a coincidental peak demand of 27.9 megawatts, thus leaving an available capacity of $167.1 \mathrm{MW}$. The 100/200 Areas electrical system 20-year power forecast shows a significant increase due to the primary mission change from production to cleanup. The twenty-year power forecast for the 100/200 Areas is:

$\begin{array}{llllllll}\text { Fiscal Year } & 1996 & 1997 & 1998 & 1999 & 2004 & 2009 & 2014 \\ \text { Megawatts } & 32.4 & 33.2 & 35.8 & 37.9 & 55.0 & 67.3 & 72.3\end{array}$

The 300 Area electrical system has two 20 megavolt-ampere (MVA) transformers and one 7.5 MVA transformer for a usable capacity of $22.0 \mathrm{MW}$. The system has a coincidental peak demand of $13.6 \mathrm{MW}$, thus leaving an available capacity of $8.4 \mathrm{MW}$. The 300 Area electrical system power forecast shows only a slight increase over the next 20 years:

\section{Fiscal Year $\quad 1996199719981999200420092014$ \\ $\begin{array}{lllllllll}\text { Megawatts } & 16.3 & 15.8 & 16.4 & 17.1 & 17.1 & 16.9 & 16.9\end{array}$}

The following are descriptions for tasks that will be completed by the Electrical Utilities function:

Operations: operations management and supervision, electrical utilities engineering team leader, systems protection engineering, systems/technical engineering, engineering management, environmental compliance, administrative support, and electrical dispatching.

Administration: electrical utilities manager, administrative support, technical support management and supervision, energy management engineering, reporting and support, plant engineering administration, technical support, procedure development, and submittal of quarterly reports regarding the status of corrective action plans for the EM-25 operational assessments of Utilities. 
Maintenance: maintenance management and supervision, administrative support, craft support, corrective maintenance, preventive maintenance, predictive maintenance, outage response, training support, work management planning, work management scheduling, plant engineering maintenance, material coordination, and performance measurement administrator. The backlog of work for crafts assigned to the Electrical Utilities function averages approximately 3,826 hours per month. Approximately 10 preventive maintenance and calibration work packages, and approximately 134 corrective maintenance and modification work packages are worked each month.

Maintenance Support From Others: design services drawing maintenance, design services document control, drawing upgrade as-building, software support, chlorinator serviceman, janitorial service, pesticide service, craft support, generator repair, training support, traffic inspections, asbestos support, hazardous waste support, HPT support, carpenter support, weed control, fab shop support, transportation services, and excess material support.

Upgrades/Additions: The following are planned or ongoing upgrade/addition projects scheduled for FY 1996.

Energy Management Projects, WBS 6.8.5:

- E-027, Reconfigure 230kV Transmission System. This energy savings project will be completed in FY 1996. This project provides for a new distribution line which eliminates an obsolete and inefficient substation in the 100 Area.

Landlord Program Capital Equipment Not Related to Construction (CENRTC), WBS 7.5.3:

- SCADA Computer Replacement (2F3E5A). This project will carryover from FY 1995.

- 251W Communications Recorder. A new communication recorder will be provided for electrical utilities.

- Smart Ground Impedance Meter. This new piece of equipment will improve personnel protection.

- Site Mapping Support Equipment. New equipment such as GPS receiver, file server, workstations, and fiber optics will be purchased to provide electrical utilities support for the site mapping system. 


\subsubsection{Assumptions and Constraints.}

\subsection{Assumptions.}

- The electrical transmission and distribution system, operated and maintained by the Electrical Utilities function, is essential to its customers and their ability to conduct Hanford mission specific activities.

- The Utility Department is required to comply. with the conduct of operation 18 chapters (DOE Order 5480.19) as defined by the applicability matrix for the department. The staffing of the department as reflected in this plan assumed that the applicability matrix would be revised to reduce the compliance level of the order. Until the matrix is revised, full compliance cannot be attained as the available staff is not sufficient to fulfill the tasks required for such compliance.

- This budget request will cover normal operating costs. Any unusual events such as a major failure of a system or component, or increases in site assessments would require additional funding to continue operations.

- DOE-RL is a federal entity and receives priority firm power from BPA. This is the same wholesale rate schedule that public utility districts and municipalities purchase power from BPA for resale to their consumers. The present contract, established in 1982 and lasting until 2002, is revised every two years. The current demand rate is $\$ 4.141 /$ kilowatt $(\mathrm{kw})$ and the energy rates are $\$ 0.02217 /$ kilowatt-hour (kwh) for September through March and $\$ 0.01629 / \mathrm{kwh}$ for April through August. These charges average out to a rate of $\$ 0.027 / \mathrm{kwh}$. The contract requires a five-year power forecast and provides for full service requirements. Electrical usage increases greater than $10 \mathrm{MW}$ in a given year will receive penalty charges. This plan assumes that these rates will increase by no more than $15 \%$.

- Electrical needs are expected to increase slowly over the next five years based primarily on new loads from facility conversions from steam heating to conditioned air. Significant requirement increases are forecasted in the outyears to meet TWRS demand projections.

\subsection{Constraints.}

- Individuals funded in "below the line" workscope will continue charging to electrical utilities cost accounts until approval is given to eliminate the identified positions. When the approval is given, the remaining funding will be returned to $\mathrm{RL}$ through a baseline change request. 
6.1.5.5 Regulatory Requirements. The Electrical Utilities function is also required to comply with the following federal regulations, state regulations, and DOE orders, as noted:

29 CFR 1910, Occupational Safety and Health Standards for General Industry

DOE Order 5480.19, (Except Chapter 9), Conduct of Operations

DOE Order 4330.4B, (Chapter I), Maintenance Management Program

DOE Order 5000.3B, Occurrence Reporting

DOE Order 5400.1, (Section 1.4.B) Waste Minimization Efforts to Reduce the Volume and Toxicity of Generated Wastes

DOE Order 4330.1, Maintenance of Property

DOE Order 4330.2C, In-House Energy Management

DOE Order 4540.1A, Utility Acquisition and Management

DOE Order 6430.1A, Chapters VIII/XIII - General Design Criteria, Exterior Electrical Systems, and Chapter XIII - Energy Conservation and Use of Renewable Energy Sources

29 CFR 1904.1-.22, Recording and Reporting Occupational Injuries and Illnesses

40 CFR 265.194, Basic RCRA Operating Requirements

40 CFR 265.196, RCRA Waste Removal Regulations

40 CFR 372.30, EPCRA Reporting Requirements

40 CFR 761.30, Inspection of PCB Transformers

WAC 173-303-71/173-303-9904, Regulation of PCB Oils from Transformers

WAC 173-303-350/40 CFR 265.51, Facility Contingency/Emergency Plans

WAC 173-303-200, Record Keeping for 90-Day Accumulation Areas

WAC 173-303-340, Records of Testing and Maintenance of Emergency Equipment

WAC 173-303-360, Building Emergency Responsibilities and Requirements

WAC 173-303-070-110, Dangerous Waste Designation 
WAC 173-303-120, General Recycling Requirements

WAC 173-303-140-141, Prohibitions and Restrictions - Land Disposal Restrictions

WAC 173-303-145/173-303-150, Spills/Discharges Into the Environment

WAC 296-45, Electrical Workers Safety Rule

10 CFR 436, Federal Energy Management and Planning Programs

Executive Order No. 12003, Submittal of 10-year plans for energy conservation with respect to Government buildings.

National Electrical Code

National Electrical Safety Code

Energy Policy Act of 1992 


\begin{tabular}{|c|c|c|c|c|c|c|c|c|c|}
\hline $\begin{array}{l}\text { Work } \\
\text { Breakdown } \\
\text { Structure } \\
\text { Dictionary }\end{array}$ & \multicolumn{6}{|c|}{$\begin{array}{l}\text { Westinghouse Hanford Company } \\
\text { Electrical Utilities } \\
\text { Part } 1 \text { - Summary } \\
\text { (Dollars in 000's) }\end{array}$} & \multicolumn{3}{|c|}{$\begin{array}{l}\text { FY } 1996 \\
\text { Indirect } \\
\text { Program Plan } \\
\text { Rev. \# } 0 \\
25-\text { Sep-95 }\end{array}$} \\
\hline Cost Account Number & \multicolumn{6}{|c|}{$\begin{array}{l}\text { Cost Account Title } \\
\text { Electrical Utilities }\end{array}$} & \multicolumn{3}{|c|}{$\begin{array}{l}\text { Proposed Rate: } \\
\text { (Rated Service Pool Only) }\end{array}$} \\
\hline $\begin{array}{l}\text { SMS WBS Number } \\
6.8 .1 .4\end{array}$ & \multicolumn{6}{|c|}{$\begin{array}{l}\text { SMS Title } \\
\text { Electrical Utilities }\end{array}$} & \multicolumn{3}{|c|}{$\begin{array}{ll}\text { G\&A } & \text { Funding Source: } \\
\end{array}$} \\
\hline RL SMS Program Manager & \multicolumn{6}{|c|}{ W.A. Rutherford } & \multicolumn{3}{|l|}{ SWS } \\
\hline Cost Account Manager & \multicolumn{6}{|l|}{ R.L. Fritz } & \multicolumn{3}{|l|}{ OST } \\
\hline WHC SMS Program Manager & \multicolumn{6}{|l|}{ G.A. Harvey } & \multicolumn{3}{|l|}{ DOH } \\
\hline Financial Manager & \multicolumn{6}{|l|}{ M.A. Davis } & \multicolumn{3}{|l|}{ MGT PRO } \\
\hline Responsible Analyst & \multicolumn{6}{|l|}{ TS. Adams } & \multirow{2}{*}{\multicolumn{3}{|c|}{\begin{tabular}{|l|} 
POOL $\mathrm{X}$ \\
FY 1996 Baseline \\
Full-Time Equivalents (FTEs)
\end{tabular}}} \\
\hline (2) & \multicolumn{3}{|c|}{$\begin{array}{l}\text { FY } 1996 \text { Approved Funding } \\
\text { Full-Time Equivalents (FTEs) }\end{array}$} & \multicolumn{3}{|c|}{$\begin{array}{l}\text { FY } 1996 \text { Unfunded } \\
\text { Full-Time Equivalents (FTEs) }\end{array}$} & & & \\
\hline TYPE OF FTE & Exempt & \begin{tabular}{|l|} 
Non-Exempt \\
\end{tabular} & Bargaining & Exempt & Non-Exempt & Bargaining & \begin{tabular}{|l|} 
Exempt \\
\end{tabular} & Non-Exempt & Bargaining \\
\hline Organizational & 26.0 & \begin{tabular}{|r|}
5.1 \\
\end{tabular} & 18.5 & & 2.0 & & 26.0 & $\begin{array}{r}7.1 \\
\end{array}$ & 18.5 \\
\hline Support & 5.1 & 0.4 & 1.5 & 2.7 & 0.8 & & 7.8 & 1.2 & 1.5 \\
\hline TOTAL FTES & 31.1 & 5.5 & 20.0 & 2.7 & 2.8 & 0.0 & 33.8 & 8.3 & 20.0 \\
\hline COST ELEMENTS & \multicolumn{3}{|c|}{ FY 1996 Approved Funding Budget } & \multicolumn{3}{|c|}{ FY 1996 Unfunded Budget } & \multicolumn{3}{|c|}{ FY 1996 Baseline Budget } \\
\hline . Labor - Regular & & & $3,548.7$ & & & 82.4 & & & $3,631.1$ \\
\hline . Labor - Overtime & & & 187.6 & & & & & & 187.6 \\
\hline 0 Total Labor & & & $3,736.3$ & & & 82.4 & & & $3,818.7$ \\
\hline 1 Materials & & & 219.8 & & & & & & 219.8 \\
\hline 2 Purchased Senvices & & & 183.3 & & & & & & 183.3 \\
\hline 3 Other Hanford & & & & & & & & & 0.0 \\
\hline 8 Revenue & & & & & & & & & 0.0 \\
\hline Subtotal originated Costs & & & 1.1 .4139 .4 & & & - & & & 3.1242218 \\
\hline 4 Site Services & & & 800.7 & & & & & & 800.7 \\
\hline 5 Internal Charges & & (n) & 212.0 & & & & & & 212.0 \\
\hline 6 IRM Support & & 1.1 .1 .1$. & 175.6 & & & & & & 175.6 \\
\hline 7 Overheads & (6. & 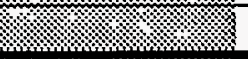 & 318.5 & $\sqrt{2}$ & & 6.0 & & & 324.5 \\
\hline TOTAL DOLLARS & 19.m. & m. & $5,646.2$ & 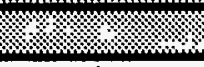 & 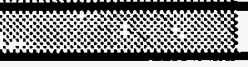 & 88.4 & & . & $5,734.6$ \\
\hline $\begin{array}{l}\text { STENATURES } \\
\text { Financial Analyst: } \\
\text { CAM: }\end{array}$ & & & $\begin{array}{l}\text { Date: } \square \\
\text { Date: }\end{array}$ & & BASELINE AF & PROVAL & & & 'ate: \\
\hline
\end{tabular}


Table A-8. Milestone Description Sheet.

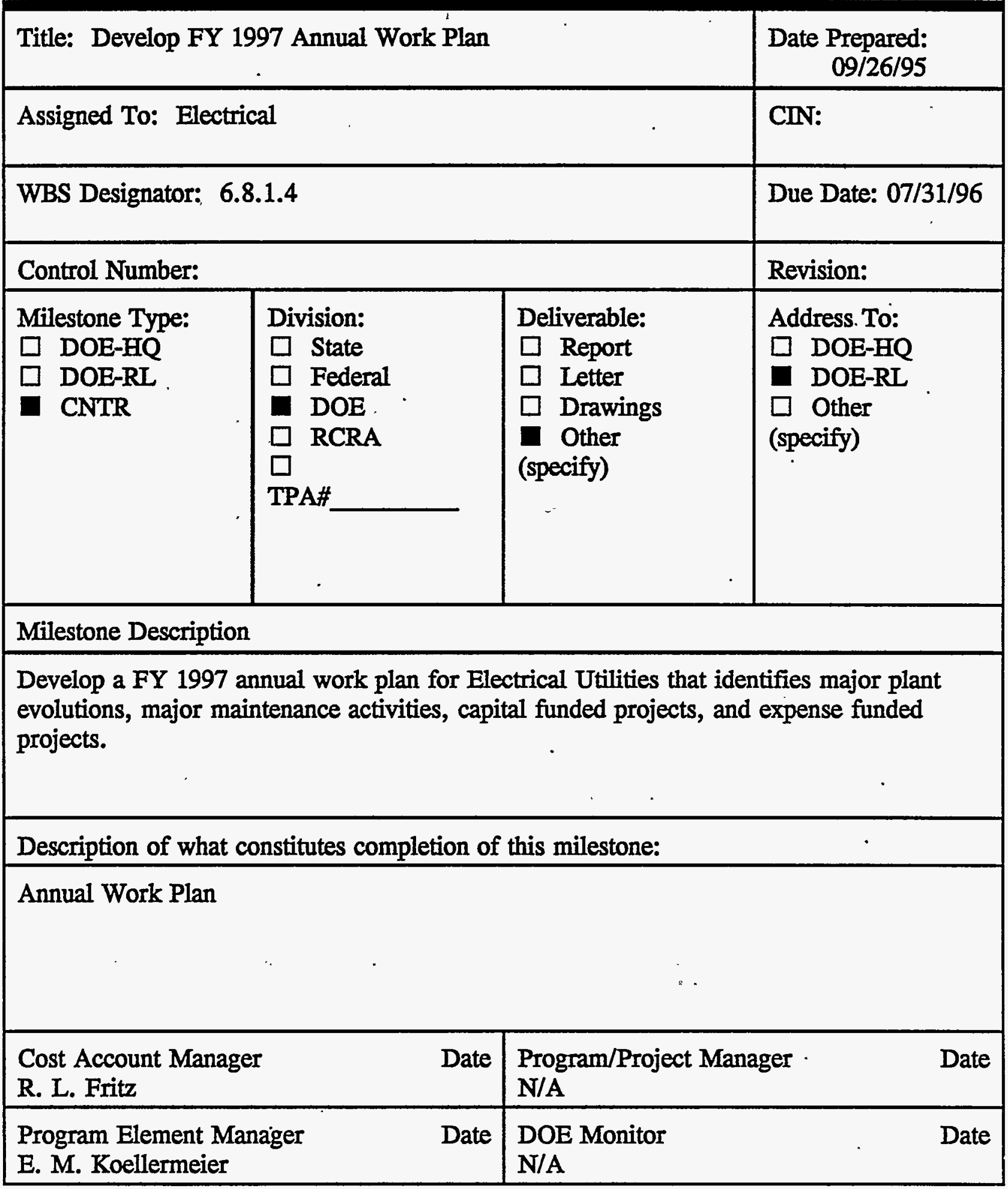


Table A-8. Milestone Description Sheet.

\begin{tabular}{|c|c|c|c|}
\hline \multicolumn{3}{|c|}{ Title: Submit 5-Year Electrical Forecast } & $\begin{array}{r}\text { Date Prepared: } \\
09 / 26 / 95\end{array}$ \\
\hline \multicolumn{3}{|c|}{ Assigned To: Electrical } & CIN: \\
\hline \multicolumn{3}{|c|}{ WBS Designator: 6.8 .1 .4} & Due Date: $12 / 15 / 96$ \\
\hline \multicolumn{3}{|c|}{ Control Number: SSP-96-A04 } & Revision: \\
\hline $\begin{array}{l}\text { Milestone Type: } \\
\square \text { DOE-HQ } \\
\square \text { DOE-RI } \\
\square \text { CNTR } \\
\end{array}$ & $\begin{array}{l}\text { Division: } \\
\square \text { State } \\
\square \text { Federal } \\
\square \text { DOE } \\
\square \text { RCRA } \\
\square \\
\text { TPA\# }\end{array}$ & $\begin{array}{l}\text { Deliverable: } \\
\square \text { Report } \\
\square \text { Letter } \\
\square \text { Drawings } \\
\square \text { Other } \\
\text { (specify) }\end{array}$ & $\begin{array}{l}\text { Address To: } \\
\square \text { DOE-HQ } \\
\square \text { DOE-RL } \\
\square \text { Other } \\
\text { (specify) } \\
\text {, }\end{array}$ \\
\hline
\end{tabular}

Milestone Description

Develop a 5-Year Load Forecast.

Description of what constitutes completion of this milestone:

Submittal of 5-year load forecast projections to RL.

\begin{tabular}{|c|c|}
\hline $\begin{array}{l}\text { Cost Account Manager } \\
\text { R. L. Fritz Som Pate }\end{array}$ & $\begin{array}{l}\text { Program/Project Mhager } \\
\text { G. A. Harvey }\end{array}$ \\
\hline $\begin{array}{l}\text { Program Element Manager } \\
\text { E. M. Koellermeier fim Late }\end{array}$ & $\begin{array}{l}\text { DOE Monitor } \\
\text {-W. A. Rutherford }\end{array}$ \\
\hline
\end{tabular}


Table A-8. Milestone Description Sheet.

\begin{tabular}{|c|c|c|c|}
\hline \multicolumn{3}{|c|}{ Title: Submit 20-Year Load Forecast } & $\begin{array}{r}\text { Date Prepared: } \\
09 / 26 / 95\end{array}$ \\
\hline \multicolumn{3}{|c|}{ Assigned To: Electrical } & CIN: \\
\hline \multicolumn{3}{|c|}{ WBS Designator: 6.8 .1 .4} & Due Date: $12 / 01 / 95$ \\
\hline \multicolumn{3}{|c|}{ Control Number: SSP-96-A03 } & Revision: \\
\hline $\begin{array}{l}\text { Milestone Type: } \\
\square \text { DOE-HQ } \\
\square \text { DOE-RL } \\
\square \text { CNTR }\end{array}$ & $\begin{array}{l}\text { Division: } \\
\square \text { State } \\
\square \text { Federal } \\
\text { DOE } \\
\square \text { RCRA } \\
\square \\
\text { TPA\# }\end{array}$ & $\begin{array}{l}\text { Deliverable: } \\
\square \text { Report } \\
\square \text { Letter } \\
\square \text { Drawings } \\
\text { Other } \\
\text { (specify) }\end{array}$ & $\begin{array}{l}\text { Address To: } \\
\square \text { DOE-HQ } \\
\square \text { DOE-RL } \\
\square \text { Other } \\
\text { (specify) }\end{array}$ \\
\hline
\end{tabular}

Milestone Description

Develop a 20-Year Load Forecast.

Description of what constitutes completion of this milestone:

Submittal of 20-year load forecast projections to $R L$ for Bonneville Power Administration (BPA).

\begin{tabular}{|c|c|}
\hline $\begin{array}{l}\text { Cost Account Manager } \\
\text { R. L. Fritz Date } \\
\text { Domplam for }\end{array}$ & $\begin{array}{l}\text { Program/Project Mafrager } \\
\text { G. A. Harvey }\end{array}$ \\
\hline $\begin{array}{l}\text { Program Element Manager } \\
\text { E. M. Koellermeier Zm turlth. } 9 / 2 z\end{array}$ & W. A. Rutherfor \\
\hline
\end{tabular}




\subsubsection{Sanitary Sewers [WBS 6.8.1.5]}

6.1.6.1 Mission/Vision. The mission of the Sanitary Sewers function is to provide sanitary sewer services by creatively adapting to meet the needs of the Hanford mission. The function's vision is to be valued as a resource that is customer oriented, responsive, cost efficient, safe, and highly effective.

\subsubsection{Goals and Objectives. See Section 6.1.1.1, Performance Measures.}

\subsubsection{Activities Performed. The Sanitary Systems function provides for consolidated} management of sewage collection, treatment, and disposal. The function is the single pointof-contact for all issues relating to the operation and maintenance of Hanford Site sanitary waste water treatment.

The function is responsible for providing services to owners of septic systems and drainfields such as pumping, surveillance, monitoring, and maintenance; operation of the $100-\mathrm{N}$ waste water lagoon, operation and maintenance of the 400 Area septic tank, drain field and sewer tie-line with WNP-2; operation and maintenance of the 300 Area collection system, septic tank and drain field; and management of the sewage disposal contract with the City of Richland. This function, except for the 300 Area and City of Richland, is funded directly by customers and programs, and the costs for this function are not included within the budget for this program plan. For FY 1996, these costs will be approximately $\$ 193,200$ (1 FTE @ \$74,700, 2 FTEs @ \$59,250 each), including overhead.

Hanford Site sewer system consists of:

- $100-\mathrm{N}$ waste water treatment lagoon with the capability to treat 50,000 gallons-per-day of sanitary waste water.

- Over 80 septic tank systems with varying tank volumes and drain field capacities.

- Seven sanitary waste water holding tanks located throughout the Hanford Site.

- Two 3,000 gallon (each) sanitary waste water pumping trucks.

- A central sewage collection piping system in the 300 Area that routes facility wastes to a septic tank and drain field.

The 300 Area sewage collection system has recently been connected to the City of Richland, but is not yet in service. A contract has been established for the city to receive, treat, and dispose of the 300 Area generated sewage. When the service is initiated, this function will be responsible for operation and maintenance of the new lift stations and closure of the existing septic tanks and drain field. The city service is expected to be initiated in early FY 1996. City fees for this service will be managed through the sanitary sewer function. The cost for this service is estimated to be approximately $\$ 130,000$ for FY 96. The budget for this is included within the 300 Area Water function, WBS 6.8.1.3, 
as is the related operation, management, administration and maintenance. Current cost accounting and cost allocation to users prescribe treating 300 Area sewers in this manner. Transfer of costs to this function will be accomplished in future program plans.

The 400 Area sanitary sewer system was tied to the WNP-2 waste water treatment and disposal system in order to eliminate ground discharge of wastes. The connecting line is currently isolated since a service agreement has not been arranged between the DOE and Washington Public Power Supply System, owner of WNP-2. It is currently planned to construct a waste water treatment and disposal lagoon in the 400 Area as a substitute for the tie-line. The lagoon is expected to be in service the first part of FY 1997.

The septic systems at the Hanford Site have varying capacities and capabilities. A detailed sanitary systems inventory that contains the capacity, capability and customer usage for each system is available. The sanitary sewers function is pumping approximately 12,000 to 15,000 gallons-per-day of sanitary waste water. The sanitary waste water is transported to the 100-N lagoon for disposal, which has the capability to treat 50,000 gallons-per-day of sanitary waste water. An 80,000 gallon desludging project for the 100-N lagoon needs to completed during FY 1996 to assure the lagoon meets the sanitary waste water disposal needs of the Hanford Site. Cost for this project will be allocated to users benefiting from the use of the lagoon.

Upgrades/Additions: The following are planned or ongoing upgrade/addition projects scheduled for FY 1996.

Landlord Program General Plant Projects, WBS 7.5.4:

- L-234, 400 Area Sanitary Lagoon. The drain field in the 400 Area has failed and waste water is currently flowing directly to the ground. This project is required to bring the 400 Area sewage disposal into environmental compliance.

- Depending upon the availability of funds in FY 1996, several projects may need to be initiated to replace or negate the problems associated with failed septic systems in the 200 Areas. The project(s) will provide a modified replacement to an unfunded FY 1996 Line Item project, L-116, "200 Area Sanitary Sewer," that was intended to provide an overall fix to the 200 Area sewage treatment and disposal problems.

Landlord Program Project Identification and Scoping. WBS 7.5.5.1:

- Alternative studies are planned to determine construction options for eliminating storm water run off to the 300 Area sanitary sewer. Estimated cost is $\$ 57 \mathrm{~K}$.

- Alternative studies are planned for determining actions needed for failed septic systems in the 200 Area. These options are alternatives to construction of the FY 1996 Line Item project (L-116). Estimated cost is $\$ 120 \mathrm{~K}$. 
General Purpose Facilities. WBS 6.8.3:

- A project will be conducted to remove sludge from the $100-\mathrm{N}$ lagoon. Due to the constant trucking of wastes from failed septic systems to the $100-\mathrm{N}$ lagoon, the lagoon is not providing the treatment needed to decompose the solid wastes. Desludging the lagoon is required in FY 1996 in order to continue use of the facility. Cost for this project will be allocated to users benefiting from the use of the lagoon. This project will be mostly funded by the General Purpose Facility since they are the main beneficiary of the lagoon operation. Other users, such as 100-N Area occupants and 200 Area Tank Farms will be required to provide remaining funds needed.

\subsubsection{Assumptions and Constraints.}

\subsection{Assumptions.}

- The sanitary sewer function is essential to its customers and their ability to conduct Hanford specific activities.

- The FY 1996 budget assumes that all DOE orders, regulations, and requirements will remain the same throughout the fiscal year. Any changes to these documents will be reviewed and appropriate change requests will be submitted for the revised workscope.

- The sanitary sewer function will assume the operation and maintenance responsibilities for the 400 Area lagoon once Project \#L-234 is completed. This project will construct a disposal system for most of the 400 Area facilities. The waste water from these facilities will be routed to three lined lagoons through a new sewer line that will be connected to the existing 400 Area septic and sanitary system. This system is scheduled to be completed during FY 1997. When completed, the ownership of this system will remain outside the scope of this function.

- Sanitary sewer requirements are going down because they are directly tied to the size and location of the workforce. Workforce reductions of 1,000 to 3,000 workers are projected over the next two years, followed by a gradual decrease in the workforce over the next five to thirty years.

- The Utility Department is required to comply with the conduct of operation 18 chapters (DOE Order 5480.19) as defined by the applicability matrix for the department. The staffing of the department as reflected in this plan assumed that the applicability matrix would be revised to reduce the compliance level of the order. Until the matrix is revised, full compliance cannot be attained as the available staff is not sufficient to fulfil the tasks required for such compliance. 


\subsection{Constraints. None.}

6.1.6.5 Regulatory Requirements. Sanitary Sewers is required to comply with the following federal regulations, state regulations, and DOE orders:

29 CFR 1910, Occupational Safety and Health Standards for General Industry

DOE Order 5480.19, Conduct of Operations

DOE Order 5000.3B, Occurrence Reporting

DOE Order 5400.1, (Section 1.4.B) Waste Minimization Efforts to Reduce the Volume and Toxicity of Generated Wastes

29 CFR 1904.1-.22, Recording and Reporting Occupational Injuries and Illnesses

40 CFR 265.196, RCRA Waste Removal Regulations

40.CFR 372.30, EPCRA Reporting Requirements

WAC 246-272, Waste Water Treatment requirements

WAC 173-303-350/40 CFR 265.51, Facility Contingency/Emergency Plans

WAC 173-303-200, Record Keeping for 90-Day Accumulation Areas

WAC 173-303-340/360, Bldg. Emergency Responsibilities, Requirements, and Testing

WAC 173-303-120, General Recycling Requirements

WAC 173-303-140-141, Prohibitions and Restrictions - Land Disposal Restrictions

WAC 173-303-145/173-303-150, Spills and Discharges Into the Environment 
Table A-10. Milestone Description Sheet.

\begin{tabular}{|c|c|c|c|}
\hline \multicolumn{3}{|c|}{ Title: Develop FY 1997 Annual Work Plan } & $\begin{array}{r}\text { Date Prepared: } \\
09 / 26 / 95\end{array}$ \\
\hline \multicolumn{3}{|c|}{ Assigned To: Sanitary Sewers } & CIN: \\
\hline \multicolumn{3}{|c|}{ WBS Designator: 6.8 .1 .5} & Due Date: $07 / 31 / 96$ \\
\hline \multicolumn{3}{|l|}{ Control Number: } & Revision: \\
\hline $\begin{array}{l}\text { Milestone Type: } \\
\square \text { DOE-HQ } \\
\square \text { DOE-RL } \\
\square \text { CNTR }\end{array}$ & $\begin{array}{l}\text { Division: } \\
\square \text { State } \\
\square \text { Federal } \\
\text { DOE } \\
\square \text { RCRA } \\
\square \\
\text { TPA\# }\end{array}$ & $\begin{array}{l}\text { Deliverable: } \\
\square \text { Report } \\
\square \text { Letter } \\
\square \text { Drawings } \\
\square \text { Other } \\
\text { (specify) }\end{array}$ & $\begin{array}{l}\text { Address To: } \\
\square \text { DOE-HQ } \\
\square \text { DOE-RL } \\
\square \text { Other } \\
\text { (specify) }\end{array}$ \\
\hline \multicolumn{4}{|l|}{ Milestone Description } \\
\hline \multicolumn{4}{|c|}{$\begin{array}{l}\text { Develop FY } 1997 \text { annual work plan for Sanitary Sewers that identifies major plant } \\
\text { evolutions, major maintenance activities, capital funded projects, and expense funded } \\
\text { projects. }\end{array}$} \\
\hline \multicolumn{4}{|c|}{ Description of what constitutes completion of this milestone: } \\
\hline \multicolumn{4}{|l|}{ Annual Work Plan } \\
\hline \multicolumn{2}{|l|}{$\begin{array}{l}\text { Cost Account Manager } \\
\text { J. L. Day }\end{array}$} & \multicolumn{2}{|c|}{$\begin{array}{l}\text { Program/Project Manager Date } \\
\text { N/A }\end{array}$} \\
\hline \multicolumn{2}{|c|}{$\begin{array}{l}\text { Program Element Manager } \\
\text { E. M. Koellermeier }\end{array}$} & \multicolumn{2}{|c|}{$\begin{array}{ll}\text { DOE Monitor } & \text { Date } \\
\text { N/A } & \end{array}$} \\
\hline
\end{tabular}




\subsubsection{Sanitary Solid Waste [WBS 6.8.1.6]}

6.1.7.1 Mission/Vision. The mission of the Sanitary Solid Waste function is to provide for the collection and disposal of sanitary solid waste generated on the Hanford Site. The function vision is to be valued as a resource that is customer oriented, responsive, cost efficient, safe, reliable, highly effective and environmentally responsible.

\subsubsection{Goals and Objectives.}

- $\quad$ See Section 8.1.1.1, Performance Measures

- Complete smooth transition from disposition of non-hazardous solid wastes at Hanford Landfill to disposition at an off-site landfill.

- Assist DOE to insure agreement with off-site facility is in place by October 1, 1995.

- Implement hauling schedules corresponding to contract requirements within 20 working days of contract award.

- Complete smooth transition from disposition of drums, medical waste, and asbestos at Hanford Landfill to disposition at an off-site facility.

- Have contract with off-site facility in place by December 31, 1995.

- Provide information to customers on requirements for waste disposition by 10 days after contract award.

- Continue emphasis on safety record and reduce lost work day cases below FY 1995.

- Submit plans to Department of Energy for closure of the central landfill by December 31, 1995.

6.1.7.3 Activities Performed. The Sanitary Solid Waste Disposal Unit of the Transportation Department is responsible for maintaining and operating the Central Waste Landfill, the Inert Waste Landfill at Pit 9, waste collection dumpsters and other containers, and compactor waste collection and waste container transport vehicles. Approximately 30,000 cubic yards of waste is expected to be received at the Central Waste Landfill and 50,000 cubic yards received at the Inert Waste Landfill in FY96. The Central Waste Landfill is expected to cease waste disposal operation in March of 1996 at which time the wastes generated will be routed to offsite providers of waste disposal. The Inert Waste Landfill will remain in use for the foreseeable future.

Included with maintaining and operating the Central Waste Landfill is environmental monitoring and development and implementation of landfill closure. In FY96 a closure and 
Post-Closure plan will be submitted to the Washington State Department of Ecology. Environmental monitoring of the landfill through in place wells and sampling stations plus new wells as may be required will take place into the foreseeable future.

There is expected to be approximately 300 dumpsters situated on the Hanford site. These dumpsters will be serviced by the Sanitary Solid Waste function and the wastes transported to the Central Waste Landfill and on or before March of 1996 transported to the City of Richland Landfill for a negotiated rate of $\$ 43.29$ per ton. Contracts for disposal of asbestos, medical and drums through an offsite provider is in process. These wastes will be disposed of in the Central Waste Landfill and on or before March of 1996 provided to the offsite contractor(s).

Related Activity: Landlord Program Project Identification and Scoping, WBS 7.5.5.1

Development of the Central Waste Landfill closure plan is being conducted under the Landlord Program, WBS 7.5.5.1. In FY 1996 the planned effort is estimated to cost $\$ 85,000$. This supports the milestone "landfill closure plan(s) submittal" and other related activities.

It is further contemplated that the effort to implement the closure plan would be funded by the Landlord Program, WBS 7.5.2 Expense Funded Projects, as proposed in future Activity Data Sheet submittals and/or Multi-Year Program Plans.

\subsubsection{Assumptions and Constraints.}

\subsection{Assumptions.}

- Contracts for offsite disposal municipal wastes will be in place on October 1, 1995 and contracts for disposal of asbestos, medical and drum wastes will be in place by December 31, 1995. Contract fees are estimated purposes of this plan since contracts are not placed.

- The State of Washington approval of the Central Waste Landfill closure plan will be given by March 31, 1996.

- The amount of solid sanitary waste, in the form of garbage, is directly related to workforce size. The amount of garbage reduction is expected to become more significant as recycling efforts expand and as new laws restricting landfill disposal are enacted.

6.1.7.4.2 Constraints. Unfunded workscope of providing Central Waste Landfill soil gas survey may impact completion of the landfill closure plan and approval by the State. The soil gas survey will provide data on the extent of groundwater contamination and possible remediation needs. 
Funding source for implementing Central Waste Landfill closure actions including corrective action plan for ground water remediation, other than immediate notification of customers and sign posting, has not be identified.

\subsubsection{Regulatory Requirements.}

Chapter 173-304 WAC Minimum Functional Standards for Solid Waste Handling 49 CFR Code of Federal Regulations Parts 100 through 177

Federal Motor Carrier Safety Regulations Title 49 CFR Code of Federal Regulations Parts 40, 325, 382, 383, 385, 386, 387, 390-397, 399 


\begin{tabular}{|c|c|c|c|c|c|c|c|c|c|}
\hline $\begin{array}{l}\text { Work } \\
\text { Breakdown } \\
\text { Structure } \\
\text { Dictionary }\end{array}$ & \multicolumn{6}{|c|}{$\begin{array}{c}\text { Westinghouse Hanford Company } \\
\text { Sanitary Solid Waste } \\
\text { Part } 1 \text { - Summary } \\
\text { (Dollars in 000's) }\end{array}$} & \multicolumn{3}{|c|}{$\begin{array}{l}\text { FY } 1996 \\
\text { Indirect } \\
\text { Program Plan } \\
\text { Rev. \# } 0 \\
25-\text { Sep-95 }\end{array}$} \\
\hline Cost Account Number & \multicolumn{6}{|c|}{$\begin{array}{l}\text { Cost Account Title } \\
\text { Sanitary Solid Waste }\end{array}$} & \multicolumn{3}{|c|}{$\begin{array}{l}\text { Proposed Rate: } \\
\text { (Rated Service Pool Only) }\end{array}$} \\
\hline $\begin{array}{l}\text { SMS WBS Number } \\
\text { 6.8.1.6 }\end{array}$ & \multicolumn{6}{|c|}{\begin{tabular}{|l|} 
SMS Title \\
Sanitary Solid Waste
\end{tabular}} & \multicolumn{3}{|c|}{$\begin{array}{r}\text { Funding Source: } \\
\end{array}$} \\
\hline RL SMS Program Manager & \multicolumn{6}{|c|}{ W.A. Rutherford } & \multicolumn{3}{|l|}{ sws } \\
\hline Cost Account Manager & \multicolumn{6}{|l|}{ K.D. Johnson } & \multicolumn{3}{|l|}{ OST } \\
\hline WHC SMS Program Manager & \multicolumn{6}{|l|}{ G.A. Harvey } & \multicolumn{3}{|l|}{ DOH } \\
\hline Financial Manager & \multicolumn{6}{|l|}{ M.A. Davis } & \multicolumn{3}{|l|}{\begin{tabular}{|l|} 
MGT PRO \\
\end{tabular}} \\
\hline Responsible Analyst & \multicolumn{3}{|c|}{$\begin{array}{l}\text { FY } 1996 \text { Approved Funding } \\
\text { Full-Time Equivalents (FTEs) }\end{array}$} & \multicolumn{3}{|c|}{$\begin{array}{l}\text { FY } 1996 \text { Unfunded } \\
\text { Full-Time Equivalents (FTEs) }\end{array}$} & \multicolumn{3}{|c|}{\begin{tabular}{|l|} 
POOL $X$ \\
FY 1996 Baseline \\
Full-Time Equivalents (FTEs)
\end{tabular}} \\
\hline TYPE OF FTE & Exempt & Non-Exempt & Bargaining & Exempt & Non-Exempt & Bargaining & Exempt & Non-Exempt & Bargaining \\
\hline Organizational & 1.0 & 0.5 & 3.2 & & & & 1.0 & 0.5 & 3.2 \\
\hline Support & 0.3 & & $\begin{array}{ll}\cdot 0.1 \\
\end{array}$ & & & & 0.3 & 0.0 & 0.1 \\
\hline TOTAL FTES & 1.3 & 0.5 & 3.3 & 0.0 & 0.0 & 0.0 & 1.3 & 0.5 & 3.3 \\
\hline COST ELEMENTS & \multicolumn{3}{|c|}{ FY 1996 Approved Funding Budget } & \multicolumn{3}{|c|}{ FY 1996 Unfunded Budget } & \multicolumn{3}{|c|}{ FY 1996 Baseline Budget } \\
\hline . Labor-Regular & 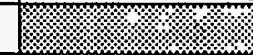 & 8 & 274.4 & & & 0.0 & & & 274.4 \\
\hline . Labor - Overtime & !: & (1.2. & 12.2 & & & & & & 12.2 \\
\hline 0 Total Labor & 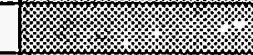 & 1010 & 286.6 & & & 0.0 & & & 286.6 \\
\hline 1 Materials & "Iय & 1.11: & 21.7 & & & & & \$ & 21.7 \\
\hline 2 Purchased Services & & 2 & 483.9 & & & & & & 483.9 \\
\hline 3 Other Hanford & & & 7.0 & & & & & 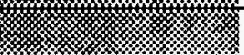 & 7.0 \\
\hline 8 Revenue & & & & & & & & & 0.0 \\
\hline Subtotal Originated Costs. & & & \% +799.2 & & & \% & 泣 & & ২ং 7992 \\
\hline 4 Site Services & 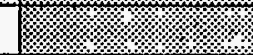 & I & 180.7 & & & & & & 180.7 \\
\hline 5 Internal Charges & 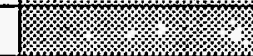 & & 10.0 & & & & 10 & - & 10.0 \\
\hline 6 IRM Support & & & 8.2 & & & & 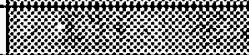 & & 8.2 \\
\hline 7 Overheads & 1 & आI: & 58.1 & & 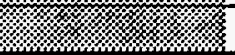 & & 1: & 2: & 58.1 \\
\hline TOTALDOLLARS & 1 & ? & $1,056.2$ & (3) & m & 0.0 & 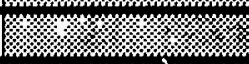 & $2=1$ & $1,056.2$ \\
\hline $\begin{array}{l}\text { SIGNATURES } \\
\text { Financial Analyst: } \\
\text { CAM: }\end{array}$ & & -5 & $\begin{array}{l}\text { Date: } \\
\text { Date: }\end{array}$ & & BASELINEAPI & PROVAL & & & Date: \\
\hline
\end{tabular}


Table A-12. Milestone Description Sheet.

\begin{tabular}{|c|c|c|c|}
\hline \multicolumn{3}{|c|}{ Title: Landfill Closure Plan Submittal } & $\begin{array}{r}\text { Date Prepared: } \\
09 / 26 / 95\end{array}$ \\
\hline \multicolumn{3}{|c|}{ Assigned To: Sanitary Solid Waste } & CIN: \\
\hline \multicolumn{3}{|c|}{ WBS Designator: 6.8 .1 .6} & Due Date: $12 / 31 / 95$ \\
\hline \multicolumn{3}{|c|}{ Control Number: SSP-96-A06 } & Revision: \\
\hline $\begin{array}{l}\text { Milestone Type: } \\
\square \text { DOE-HQ } \\
\square \text { DOE-RL } \\
\square \text { CNTR }\end{array}$ & $\begin{array}{l}\text { Division: } \\
\square \text { State } \\
\square \text { Federal } \\
\square \text { DOE } \\
\square \text { RCRA } \\
\square \\
\text { TPA\# }\end{array}$ & $\begin{array}{l}\text { Deliverable: } \\
\square \text { Report } \\
\square \text { Letter } \\
\square \text { Drawings } \\
\square \text { Other } \\
\text { (specify) }\end{array}$ & $\begin{array}{l}\text { Address To: } \\
\square \text { DOE-HQ } \\
\square \text { DOE-RL } \\
\square \text { Other } \\
\text { (specify) }\end{array}$ \\
\hline \multicolumn{4}{|c|}{ Milestone Description } \\
\hline \multicolumn{4}{|c|}{$\begin{array}{l}\text { Develop plan(s) for closure of the central landfill for Washington State Department of } \\
\text { Ecology review and approval. This milestone supports ceasing central landfill operation } \\
\text { by March 31, 1996. }\end{array}$} \\
\hline \multicolumn{4}{|c|}{ Description of what constitutes completion of this milestone: } \\
\hline \multicolumn{4}{|c|}{ Submit by letter to DOE-RL closure plan(s) for the central landfill. } \\
\hline \multicolumn{2}{|c|}{$\begin{array}{l}\text { Cost Account Manager } \\
\text { K. D. Johnson Late }\end{array}$} & \multicolumn{2}{|c|}{$\begin{array}{l}\text { Program/Project Manfger } \\
\text { G. A. Harvey } a / 22 / 95\end{array}$} \\
\hline \multicolumn{2}{|c|}{$\begin{array}{l}\text { Program Element Manager } \\
\text { E. M. Koellermeier Date }\end{array}$} & \multicolumn{2}{|c|}{$\begin{array}{l}\text { DOE Monitor } \\
\text { W. A. Rutherford }\end{array}$} \\
\hline
\end{tabular}


Table A-12. Milestone Description Sheet.

\begin{tabular}{|c|c|c|c|}
\hline \multicolumn{3}{|c|}{ Title: Initiate Contract, Offsite Waste Disposal } & $\begin{array}{r}\text { Date Prepared: } \\
09 / 26 / 95\end{array}$ \\
\hline \multicolumn{3}{|c|}{ Assigned To: Sanitary Solid Waste } & CIN: \\
\hline \multicolumn{3}{|c|}{ WBS Designator: 6.8 .1 .6} & Due Date: $12 / 28 / 95$ \\
\hline \multicolumn{3}{|c|}{ Control Number: SSP-96-A05 } & Revision: \\
\hline $\begin{array}{l}\text { Milestone Type: } \\
\square \text { DOE-HQ } \\
\square \text { DOE-RL } \\
\square \text { CNTR }\end{array}$ & $\begin{array}{l}\text { Division: } \\
\square \text { State } \\
\square \text { Federal } \\
\square \text { DOE } \\
\square \text { RCRA } \\
\square \\
\text { TPA\# }\end{array}$ & $\begin{array}{l}\text { Deliverable: } \\
\square \text { Report } \\
\square \text { Letter } \\
\square \text { Drawings } \\
\text { Other } \\
\text { (specify) Contract }\end{array}$ & $\begin{array}{l}\text { Address To: } \\
\square \text { DOE-HQ } \\
\square \text { DOE-RL } \\
\square \text { Other } \\
\text { (specify) }\end{array}$ \\
\hline \multicolumn{4}{|c|}{ Milestone Description } \\
\hline \multicolumn{4}{|c|}{$\begin{array}{l}\text { Signed contract and hauling waste to offsite vendors. Includes waste streams for asbestos, } \\
\text { medical and drums. }\end{array}$} \\
\hline \multicolumn{4}{|c|}{ Description of what constitutes completion of this milestone: } \\
\hline \multicolumn{4}{|c|}{ Verification of signed contract submitted to DOE-RL. } \\
\hline \multicolumn{2}{|c|}{ 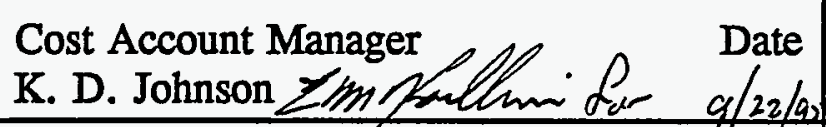 } & \multicolumn{2}{|c|}{$\begin{array}{l}\text { Program/Project Mate } \\
\text { G. A. Harvey }\end{array}$} \\
\hline \multicolumn{2}{|c|}{$\begin{array}{l}\text { Program Element Manager } \\
\text { E. M. Koellermeier \& Ym Yhithm } \% / 2 r / 9\end{array}$} & \multicolumn{2}{|c|}{$\begin{array}{l}\text { DOE Monitor } \\
\text { W. A. Rutherford }\end{array}$} \\
\hline
\end{tabular}


Table A-4. Milestone Description Sheet.

\begin{tabular}{|c|c|c|c|}
\hline \multicolumn{3}{|c|}{ Title: Submit 283W Potable Water System Tracer Study } & $\begin{array}{r}\text { Date Prepared: } \\
09 / 26 / 95\end{array}$ \\
\hline \multicolumn{3}{|c|}{ Assigned To: Water } & CIN: \\
\hline \multicolumn{3}{|c|}{ WBS Designator: 6.8 .1 .3} & Due Date: $02 / 02 / 96$ \\
\hline \multicolumn{3}{|c|}{ Control Number: SSP-95-A08 } & Revision: \\
\hline $\begin{array}{l}\text { Milestone Type: } \\
\square \text { DOE-HQ } \\
\text { DOE-RL } \\
\square \text { CNTR }\end{array}$ & $\begin{array}{l}\text { Division: } \\
\square \text { State } \\
\square \text { Federal } \\
\square \text { DOE } \\
\square \text { RCRA } \\
\square \\
\text { TPA\# }\end{array}$ & $\begin{array}{l}\text { Deliverable: } \\
\square \text { Report } \\
\square \text { Letter } \\
\square \text { Drawings } \\
\square \text { Other } \\
\text { (specify) Test Plan }\end{array}$ & $\begin{array}{l}\text { Address To: } \\
\square . \text { DOE-HQ } \\
\square \text { DOE-RI } \\
\square \text { Other } \\
\text { (specify) }\end{array}$ \\
\hline \multicolumn{4}{|c|}{ Milestone Description } \\
\hline \multicolumn{4}{|c|}{$\begin{array}{l}\text { Develop a disinfection contact time study plan ( } 200 \text { West Area Tracer Study) and submit } \\
\text { to DOE-RL for forwarding to the State Department of Health. The plan and resulting tests } \\
\text { are required per WAC 246-290-636. } \\
\text { ICF KH Water Administration will submit to DOE-RL a report on the tracer study test } \\
100 \text { days after receipt of study plan approval by the State Department of Health. An } \\
\text { additional milestone will be established reflecting this time duration after State approval. }\end{array}$} \\
\hline \multicolumn{4}{|c|}{ Description of what constitutes completion of this milestone: } \\
\hline \multicolumn{4}{|c|}{ Submittal by cover letter of the study plan to DOE-RL. } \\
\hline \multicolumn{2}{|c|}{$\begin{array}{l}\text { Cost Account Manager } \\
\text { J. M. Hache Pmeffuellon }\end{array}$} & \multicolumn{2}{|c|}{$\begin{array}{l}\text { Program/Project Marfgef } \\
\text { G. A. Harvey }\end{array}$} \\
\hline \multicolumn{2}{|c|}{$\begin{array}{l}\text { Program Element Manager } \\
\text { E. M. Koellermeier Emen }\end{array}$} & \multicolumn{2}{|c|}{ 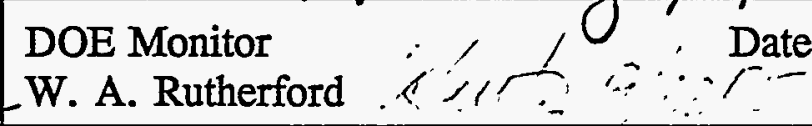 } \\
\hline
\end{tabular}




\subsection{Appendix B Transportation}





\section{.CONTENTS}

6.2 APPENDIX B - TRANSPORTATION [WBS 6.8.2] . . . . . . . B-1

6.2 .1 Mission/Vision . . . . . . . . . . . . . B-1

6.2.2 Performance Measures $\ldots \ldots \ldots \ldots \ldots \ldots \ldots \ldots \ldots$ B-1

6.2.3 Roads [WBS 6:8.2.1] .................... B-3

6.2.3.1 Goals and Objectives $\ldots \ldots \ldots \ldots \ldots \ldots \ldots$ B-3

6.2.3.2 Activities Performed ...................... B

6.2.3.3 Assumptions and Constraints . . . . . . . . . B-4

6.2.4 Rail [WBS 6.8.2.2] . . . . . . . . . . . . B-7

6.2.4.1 Goals and Objectives $\ldots \ldots \ldots \ldots \ldots \ldots \ldots \ldots$ B-7

6.2.4.2 Activities Performed $\ldots \ldots \ldots \ldots \ldots \ldots \ldots \ldots$ B-7

6.2.4.3 Assumptions and Constraints . . . . . . . . . B B-7

6.2.4.4 Regulatory Requirements . . . . . . . . . . . . B-8

6.2.5 Vehicle/Equipment [WBS 6.8.2.3] . . . . . . . . . B-10

6.2.5.1 Goals and Objectives $\ldots \ldots \ldots \ldots \ldots \ldots \ldots$. . . . . . .

6.2.5.2 Activities Performed . . . . . . . . . . . . B-10

6.2.5.3 Assumptions and Constraints . . . . . . . . . . B-11

6.2.5.4 Regulatory Requirements ............... B-11

\section{LIST OF TABLES}

B-1 WBS Dictionary, Part $1 \ldots \ldots \ldots \ldots \ldots \ldots \ldots \ldots$ B-6

B-2 WBS Dictionary, Part $1 \ldots \ldots \ldots \ldots \ldots \ldots \ldots \ldots$ B-9

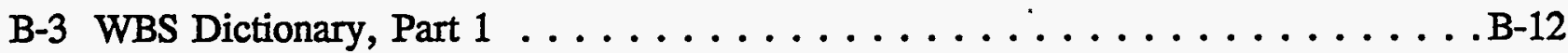





\subsection{APPENDIX B - TRANSPORTATION [WBS 6.8.2]}

\subsubsection{Mission/Vision}

The mission of the Transportation function is to operate, maintain, and project future needs' for the Hanford Site services contained within this program in support of the Hanford mission. These services are provided on a Site-wide basis.

The function's vision is to continue to be a proactive organization and strive to be a model business unit. Actions required to accomplish this mission/vision are:

- Establish clear identification of costs for products and services. This will be accomplished by expanding the work breakdown structure at the activity level to more clearly identify the costs of services being provided and to study the effects of adopting the activity-based accounting methodology. This will be done at each program element level during the period covered by this plan.

- Propose and implement process improvements

- Strengthen performance measurement techniques (dollars/cents)

- Clarify the future of the business unit through educating customers on services available and the competitiveness of the business unit compared to other onsite organizations and offsite service suppliers.

- Strive to understand and meet customers' changing needs during this period of changes in contractor responsibilities to ensure uninterrupted support of the Hanford mission.

All program elements will be conducted in a safe, environmentally sound, costeffective, and reliable manner.

\subsubsection{Performance Measures}

Vehicles and Equipment

- Maintenance billing ratio

Measurement: Comparison of available hours charged to billable work and hours charged to overhead.

Goal: Maintain or improve ratio. 


\section{Qverhead}

- Measurement: Comparison of variable overhead cost to total costs.

Goal: Reduce variable overhead costs.

\section{Roads}

- Road maintenance cost

Measurement: Comparison of maintenance per mile to comparable industry costs.

Goal: Maintain costs at or below comparable industry costs.

$\underline{\text { Rail }}$

- Rail system maintenance costs

Measurement: Comparison of maintenance cost per mile to comparable industry costs.

Goal: Maintain costs at or below comparable industry costs. 


\subsubsection{Roads [WBS 6.8.2.1]}

6.2.3.1 Goals and Objectives. Provide the safest road system possible given the manpower, funding, age, and condition of the Hanford Site road network.

- Maintain the areas designated as the 600 area in a safe condition.

- Develop the road maintenance snow removal plan by September 30, 1996

- Replace all boundary "No Trespassing" signs with new criteria signs by September 30, 1996

- Continue road sign replacement at the rate of 10 percent per year as specified in the 1990 Stone \& Webster road system audit.

Identify method to fully fund and implement a pavement management plan for the Hanford . road system. Potential methods would include direct program funding through impact fees and/or direct Landlord program funding.

Develop a road system rehabilitation program and;

- Work with Programs to identify funding for the rehabilitation program

- Review current system information and prioritize rehabilitation requirements.

6.2.3.2 Activities Performed. Maintain the Hanford road system and paving parking lots as follows:

- 302 kilometers (188 lane miles) of primary roads

- 132 kilometers (82 lane miles) of secondary roads

- 563 kilometers (350 miles) of other roads (gravel)

- 62 hectares (155 acres) of paved parking lots.

Perform maintenance work as follows:

- Inspect roads

- Repair pavements

- Maintain road shoulders

- Roads stripping as required

- Sweep roads

- Maintain signs

- Maintain plant perimeter fences

- Remove debris. 
Perform other services as follows:

- Install traffic control signs

- Install boundary fence signs, including river approaches

- Provide general Hanford Site-wide excavation

- Remove snow and sand from roads and parking lots

- Support United States Navy submarine reactor compartment burial shipments

- Support the Hanford Fire Department on a 24-hour basis for range fires and other emergencies

- Perform dust abatement

- Monitor and maintain 31 active gravel pits used by Hanford Site contractors.

\subsubsection{Assumptions and Constraints.}

\subsection{Assumptions.}

- Customer expectations for 1996 and beyond will remain constant

- Staffing will remain at the 1995 level

- Road traffic volumes will decrease with workforce reductions. Transportation of materials for TWRS, ERDF, and RCRA/CERCLA closures could create a significant increase in heavy truck traffic over some parts of the road system. Current facility demand is described in Life Cycle Strategy, Hanford Road System, May 1995.

\subsection{Constraints.}

- Staff will not be able to accommodate all customer requirements during winter months, if snow and ice removal demands are greater than available staffing

- Funding levels do not allow full routine maintenance nor any preventative maintenance or periodic rehabilitation of the road system. The road system is subject to catastrophic failure within the next five years

- Staffing will remain at the 1995 level or less. 


\subsubsection{Regulatory Requirements.}

- Federal Highway Administration DOT

- Washington State Department of Transportation (WASH DOT)

- Code of Federal Regulations (CFR) 49

- Revised Code of Washington, Title 46

- Washington Administrative Code (WAC), Title 46838

- Manual on Uniform Traffic Control Devices. 


\section{Work \\ Breakdown \\ Structure Dictionary}

Cost Account Number

SMS WBS Number

6.8.2.1

RL SMS Program Manager

Cost Account Manager WHC SMS Program Manager Financial Manager

Responsible Analyst

\section{TYPE OF FTE}

Organizational

Support

TOTAL FTES

\begin{tabular}{|l|l|}
\hline Analyst & $K$ \\
& \\
\hline E & \\
\hline & \\
\hline
\end{tabular}

COST ELEMENTS

. Labor - Regular

. Labor - Overtime

0 Total Labor

1 Materials

2 Purchased Services

3 Other Hanford

8 Revenue

Subtotal originated costs

4 Site Services

5 Internal Charges

6 IRM Support

7 Overheads

TOTAL DOLLARS

edogsts?

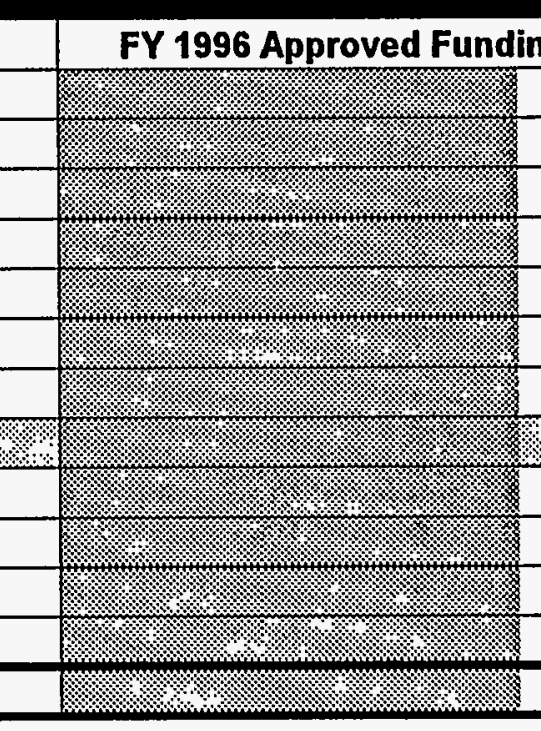

Cost Account Title

Roads Summary

SMS Title

Roads Summary

W.A. Rutherford

R.G. Ciccone

G.A. Hanvey

M.A. Davis

K. J. Milam

FY 1996 Approved Funding Full-Time Equivalents (FTEs) Exempt $\quad$ Non-Exempt Bargaining

\begin{tabular}{|r|r|r|}
\hline \multicolumn{1}{|c|}{ Exempt } & Non-Exempt & Bargaining \\
\hline 1.0 & 0.5 & 9.0 \\
\hline 0.4 & & 0.9 \\
\hline 1.4 & 0.5 & 9.9 \\
\hline
\end{tabular}

\begin{tabular}{|c|c|c|}
\hline \multicolumn{3}{|c|}{$\begin{array}{l}\text { FY } 1996 \text { Unfunded } \\
\text { Full-Time Equivalents (FTEs) }\end{array}$} \\
\hline Exempt & Non-Exempt & Bargaining \\
\hline & & \\
\hline & & \\
\hline 0. & 0.0 & 0.0 \\
\hline
\end{tabular}

\section{ing Budget}

\begin{tabular}{|r|}
\hline 619.1 \\
\hline 81.0 \\
\hline 700.1 \\
\hline 67.6 \\
\hline 5.0 \\
\hline 0.0 \\
\hline $1,005.1$ \\
\hline 20.0 \\
\hline 7.6 \\
\hline 153.2 \\
\hline $1,958.6$ \\
\hline
\end{tabular}

$1,958.6$

Date:

SIGNATURES

Financial Analyst:

CAM:

Date:
FY 1996

Indirect

Program Plan

Rev. \# 0

25-Sep-95

\section{Proposed Rate:}

(Rated Service Pool Only)

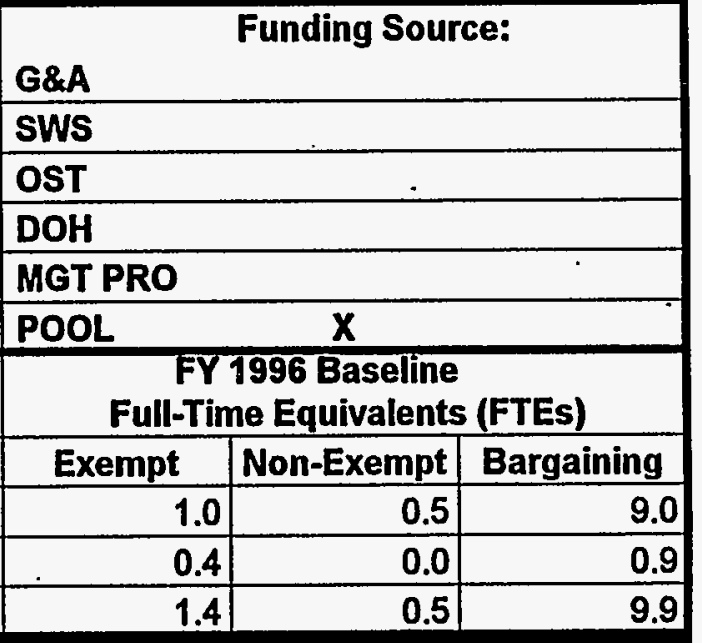

\section{FY 1996 Unfunded Budget}

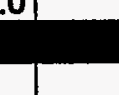

(1)

1.4
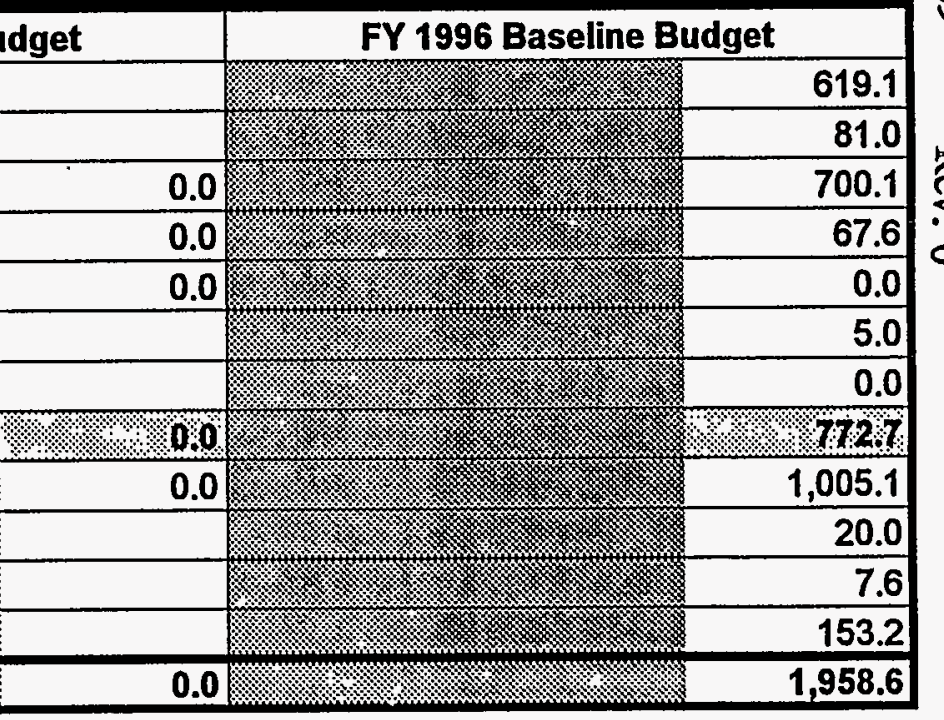

BASELINE APPROVAL 


\subsubsection{Rail [WBS 6.8.2.2]}

6.2.4.1 Goals and Objectives. Operate an industrial rail system within the confines of the Hanford Site in full compliance with DOE orders and the Code of Federal Regulations. Continue to maintain a highly successful rail operations safety program that presently exceeds 48 years without a lost time injury.

- Comply with the office of performance assessment appraisal OPA-SES-93-03, and replace joint bars on the remaining four miles of southern connection track.

- Establish a funding mechanism to put the rail system on a comparable cost basis to the road system.

\subsubsection{Activities Performed.}

6.2.4.2.1 Perform system operations as follows: Rail Operations is responsible for rail movements on the Hanford Site, as well as repair and upkeep of the Hanford rail system. Rail Operations provides delivery and switching of commercial receipts, off-plant rail shipments, and on-plant movements of bulk and liquid materials. Rail Operations also operates a Washington State certified scalehouse.

\subsection{Perform maintenance work as follows:}

- 112 kilometers (70 miles) of active track

- 122 crossings

- 156 switches

- 312,646 ties

- 1,500 signs

- 17 electrical signals

- Two bridges - two overpasses

- Right-of-way vegetation control

- Snow and sand removal

- 380 cubic meters (500 yards) of ballast added annually.

\subsubsection{Assumptions and Constraints.}

\subsection{Assumptions.}

- The Hanford railroad is the most cost effective mode of transportation for transporting construction equipment, supplies, liquid waste, core samples, and decontamination and decommissioning (D\&D) disposal and closure materials

- Hanford programs would use the railroad system if it was on a comparable cost basis to the road system. 
- The maintenance on the railroad system from Columbia Center to the 1100 Area yard cannot be reduced because of existing agreements between DOE, its predecessor and the Commercial Servicing Railroads.

- Rail traffic could drop from almost 500 cars/year to less than 100 cars/year if steam transition occurs in FY 1996. However, rail traffic is expected to more than double current levels during TWRS construction. Long range projections, for TWRS operations alone, are for traffic levels 60 percent over current. Use of rail to support D\&D, ERDF, RCRA/CERCLA closures, and Solid Waste (WRAP) Operations could drive future rail requirements much higher. Current and future facility demand are described in Life Cycle Strategy, Hanford Rail System, May 1995

\subsection{Constraints.}

- There must be advance planning and correlation between project management and Railroad Operations for future activities

- A lack of planning, involvement, and communication by potential users will limit Railroad Operations' ability to respond to service requirements in a timely manner, because of a lack of train crew operating personnel

\subsubsection{Regulatory Requirements.}

DOE Order 5480.4

Code of Federal Regulations (CFR) 23, 29, and 49

American Railway Engineering Construction Standards

Manual on Uniform Traffic Control Devices 


\begin{tabular}{|c|c|c|c|c|c|c|c|c|c|}
\hline $\begin{array}{l}\text { Work } \\
\text { Breakdown } \\
\text { Structure } \\
\text { Dictionary }\end{array}$ & \multicolumn{6}{|c|}{$\begin{array}{c}\text { Westinghouse Hanford Company } \\
\text { Rail Summary } \\
\text { Part } 1 \text { - Summary } \\
\text { (Dollars in 000's) }\end{array}$} & \multicolumn{3}{|c|}{$\begin{array}{l}\text { FY } 1996 \\
\text { Indirect } \\
\text { Program Plan } \\
\text { Rev. \# } 0 \\
25-\text { Sep-95 }\end{array}$} \\
\hline Cost Account Number & \multicolumn{6}{|c|}{$\begin{array}{l}\text { Cost Account Title } \\
\text { Rail Summary }\end{array}$} & \multicolumn{3}{|c|}{$\begin{array}{l}\text { Proposed Rate: } \\
\text { (Rated Service Pool Only) }\end{array}$} \\
\hline $\begin{array}{l}\text { SMS. WBS Number } \\
\text { 6.8.2.2 }\end{array}$ & \multicolumn{6}{|l|}{$\begin{array}{l}\text { SMS Title } \\
\text { Rail Summary }\end{array}$} & \multicolumn{3}{|c|}{ Funding Source: } \\
\hline RL SMS Program Manager & \multicolumn{6}{|c|}{ W.A. Rutherford } & \multicolumn{3}{|l|}{ sws } \\
\hline Cost Account Manager & \multicolumn{6}{|l|}{ R.G. Ciccone } & \multicolumn{3}{|l|}{ OST } \\
\hline WHC SMS Program Manager & \multicolumn{6}{|l|}{ G.A. Harvey } & \\
\hline Financial Manager & \multicolumn{6}{|l|}{ M.A. Davis } & \\
\hline Responsible Analyst & \multicolumn{3}{|c|}{$\begin{array}{l}\text { FY } 1996 \text { Approved Funding } \\
\text { Full-Time Equivalents (FTEs) }\end{array}$} & \multicolumn{3}{|c|}{$\begin{array}{l}\text { FY } 1996 \text { Unfunded } \\
\text { Full-Time Equivalents (FTEs) }\end{array}$} & \multicolumn{3}{|c|}{ 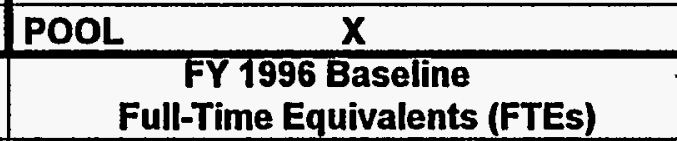 } \\
\hline TYPE OF FTE & Exempt & Non-Exempt & Bargaining & Exempt & Non-Exempt & \begin{tabular}{|l|} 
Bargaining \\
\end{tabular} & Exempt & \begin{tabular}{|l|} 
Non-Exempt \\
\end{tabular} & Bargaining \\
\hline Organizational & 2.0 & & 12.5 & & & & 2.0 & 0.0 & 12.5 \\
\hline Support & 0.1 & & 1.0 & & & & 0.1 & 0.0 & 1.0 \\
\hline TOTALFTES & 2.1 & 0.0 & 13.5 & 0.0 & 0.0 & 0.0 & 2.1 & 0.0 & 13.5 \\
\hline COST ELEMENTS & \multicolumn{3}{|c|}{ FY 1996 Approved Funding Budget } & \multicolumn{3}{|c|}{ FY 1996 Unfunded Budget } & \multicolumn{3}{|c|}{ FY 1996 Baseline Budget . } \\
\hline . Labor-Regular & (1) & 2 & 825.0 & & 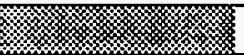 & & & & 825.0 \\
\hline . Labor - Overtime & & & 19.4 & & & & & & 19.4 \\
\hline 0 Total Labor & : & & 844.4 & & & 0.0 & & & 844.4 \\
\hline 1 Materials & 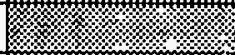 & & 51.0 & & & & & & 51.0 \\
\hline 2 Pürchased Services & & & 1.0 & & & & & & 1.0 \\
\hline 3 Other Hanford & & & & & & & & & 0.0 \\
\hline 8 Revenue & & & & & & & & & 0.0 \\
\hline Sulbtotal originated Costs & & & ४ 896,4 & & & 10.0 .0 & & & $80896 \% 4$ \\
\hline 4 Site Services & (2) & & 255.4 & & & & & & 255.4 \\
\hline 5 Internal Charges & আ & & & & & & & & 0.0 \\
\hline 6 IRM Support & (2) & 8 & 11.1 倡 & ? & & & & & 11.1 \\
\hline 7 Overheads & 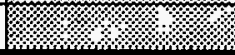 & & 200.8 & 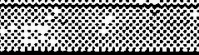 & IIISU & & ये & 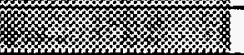 & 200.8 \\
\hline TOTALDOLLARS & 1 & r & $1,363.7$ & m? & 7 & 0.0 & 1 & 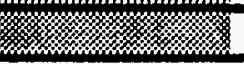 & $1,363.7$ \\
\hline $\begin{array}{l}\text { SIGNATURES } \\
\text { Financial Analyst: } \\
\text { CAM: }\end{array}$ & . & {[} & $\begin{array}{l}\text { Date: } \\
\text { Date: }\end{array}$ & & BASELINEAPI & PROVAL & & & Date: \\
\hline
\end{tabular}




\subsubsection{Vehicle/Equipment [WBS 6.8.2.3]}

6.2.5.1 Goals and Objectives. The function's goal is to be the preferred maintenance provider for RL, General Services Administration, and Hanford Site contractors.

- Be requested by GSA and Bechtel Hanford, Inc. to perform Fleet Maintenance for FY 1997 by September 30, 1996.

Perform regulated, breakdown, and preventive vehicle maintenance based on manufacturer recommendations, Department of Transportation regulations, and Hanford experience. Perform modifications to equipment based on customer requirements.

- Review preventative maintenance requirements against existing database and update frequency by March 31, 1996.

Develop and implement annual and out-year forecasts for procurement projections and capital appropriation requirements.

- Develop forecast report by June $1,1996$.

Design, develop, upgrade the vehicle Fleet Management system.

- Reduce amount of time necessary to produce records and external reports (billing and other financial reports) by September 30, 1996.

Improve overall management and utility of heavy equipment assigned to ICF KH and Westinghouse Hanford.

- Establish and operate heavy equipment pool by December 31, 1995.

6.2.5.2 Activities Performed. Activities in this function include:

- Light vehicle/General Services Administration maintenance support, 1100 Area main shop

- Bus and heavy truck maintenance, 1100 Area main shop

- Heavy equipment maintenance, 1100 Area main shop and 200E Area shop

- Construction equipment maintenance, 3000 Area shop and 600 Area work sites

- Light and heavy truck maintenance, 200E Area shop

- Material support to all shops 
- Fleet and General Services Administration support services

- Approximately 4,000 units serviced.

\subsubsection{Assumptions and Constraints.}

\subsection{Assumptions.}

- Maintenance will continue to be required on the Hanford equipment.

- Work in this category will generally decrease from FY 1995 levels based upon the following. Taxi services will be reduced or eliminated. The size of the GSA vehicle pool will be reduced. Trash pickup requirements will go down in proportion to the site workforce. An analysis of heavy equipment requirements has yet to be made, but are expected to be steady based on ERDF and ongoing site maintenance needs.

\subsection{Constraints}

- If maintenance is performed at remote locations offsite the cost and downtime will increase significantly because of transportation requirements.

- Current labor agreements are not always compatible with requirements needed to achieve competitiveness.

- Changing customer needs and equipment use are taxing both customer and shop resources. The Hanford Site infrastructure has not changed to accommodate increased activity, e.g., fuel deliveries and trash pickup.

\subsubsection{Regulatory Requirements.}

49CFR396 - Inspection, Repair and Maintenance

49CFR229 - Railroad Locomotive Safety Standards

49CFR231 - Railroad Safety Appliance Standards

49CFR232 - Railroad Power Brakes and Drawbars 


\begin{tabular}{|c|c|c|c|c|c|c|c|c|c|}
\hline $\begin{array}{l}\text { Work } \\
\text { Breakdown } \\
\text { Structure } \\
\text { Dictionary }\end{array}$ & \multicolumn{6}{|c|}{$\begin{array}{l}\text { Westinghouse Hanford Company } \\
\text { Vehicle/Equipment Summary } \\
\text { Part } 1 \text { - Summary } \\
\text { (Dollars in 000's) }\end{array}$} & \multicolumn{3}{|c|}{$\begin{array}{l}\text { FY } 1996 \\
\text { Indirect } \\
\text { Program Plan } \\
\text { Rev. \# } 0 \\
25-\text { Sep-95 }\end{array}$} \\
\hline Cost Account Number & \multicolumn{6}{|c|}{$\begin{array}{l}\text { Cost Account Title } \\
\text { Vehicle/Equipment Summary }\end{array}$} & \multicolumn{3}{|c|}{\begin{tabular}{|l} 
Proposed Rate: \\
(Rated Service Pool Only)
\end{tabular}} \\
\hline $\begin{array}{l}\text { SMS WBS Number } \\
\text { 6.8.2.3 }\end{array}$ & \multicolumn{6}{|c|}{$\begin{array}{l}\text { SMS Title } \\
\text { Vehicle/Equipment Summary }\end{array}$} & \multicolumn{3}{|c|}{ Funding Source: } \\
\hline RL SMS Program Manager & \multicolumn{6}{|c|}{ W.A. Rutherford } & \multicolumn{3}{|l|}{ sws } \\
\hline Cost Account Manager & \multicolumn{6}{|c|}{ J.F. Woods, A.C. Met? } & \multicolumn{3}{|l|}{ OST } \\
\hline WHC SMS Program Manager & \multicolumn{6}{|l|}{ G.A. Harvey } & \multirow{2}{*}{\multicolumn{3}{|c|}{\begin{tabular}{|l|} 
DOH \\
MGT PRO
\end{tabular}}} \\
\hline Financial Manager & \multicolumn{6}{|l|}{ M.A. Davis } & & & \\
\hline Responsible Analyst & \multicolumn{3}{|c|}{$\begin{array}{l}\text { FY } 1996 \text { Approved Funding } \\
\text { Full-Time Equivalents (FTEs) }\end{array}$} & \multicolumn{3}{|c|}{$\begin{array}{l}\text { FY1996 Unfunded } \\
\text { Full-Time Equivalents (FTES) }\end{array}$} & \multicolumn{3}{|c|}{$\begin{array}{c}\text { FY 1996 Baseline } \\
\text { Full-Time Equivalents (FTEs) } \\
\end{array}$} \\
\hline TYPE OF FTE & Exempt & Non-Exempt & Bargaining & Exempt & \begin{tabular}{|l|} 
Non-Exempt \\
\end{tabular} & Bargaining & Exempt & Non-Exempt & Bargaining \\
\hline Organizational & 5.5 & 3.0 & 42.6 & & & & 5.5 & 3.0 & 42.6 \\
\hline Support & 0.9 & 0.1 & 4.7 & & & & 0.9 & 0.1 & 4.7 \\
\hline TOTALFTES & 6.4 & 3.1 & 47.3 & 0.0 & 0.0 & 0.0 & 6.4 & 3.1 & 47.3 \\
\hline COST ELEMENTS & \multicolumn{3}{|c|}{ FY 1996 Approved Funding Budget } & \multicolumn{3}{|c|}{ FY 1996 Unfunded Budget } & \multicolumn{3}{|c|}{ FY 1996 Baseline Budget } \\
\hline Labor - Regular & $7 \pi$ & 1 & $3,177.7$ & & & & 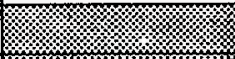 & 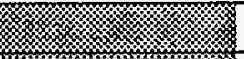 & $3,177.7$ \\
\hline . Labor - Overtime & & & & & & & & & 0.0 \\
\hline o Total Labor & 1. & : & $3,177.7$ & & & 0.0 & & & $3,177.7$ \\
\hline 1 Materials & (1) & (2) & $2,687.3$ & $=2$ & 13 & & & & $2,687.3$ \\
\hline 2 Purchased Services & 2. & & 2.5 & & & & & & 2.5 \\
\hline 3 Other Hanford & & & 20.0 & & & & & & 20.0 \\
\hline 8 Revenue & & . & $(2,080.5)$ & & & & & & $(2,080.5$ \\
\hline Subtotal originated Costs & $\sqrt{\prime \prime}$ & & . $3,807.0$ & & & 120.00 & & & $3,8,607 \%$ \\
\hline 4 Site Services & & & 686.5 & & & & & & 686.5 \\
\hline 5 Internal Charges & य. & (1) & $3,551.3$ & & & & & & $3,551.3$ \\
\hline 6 IRM Support & 1. & m & 14.6 & & & & & & 14.6 \\
\hline 7 Overheads. & 1. & I. & $1,485.7$ & 2 & & & " & X & $1,485.7$ \\
\hline TOTAL DOLLARS & 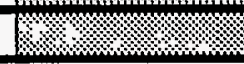 & רוn & $9,545.1$ & $\sqrt{2}$ & 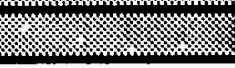 & 0.0 & 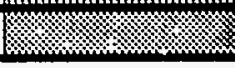 & 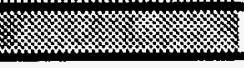 & $9,545.1$ \\
\hline $\begin{array}{l}\text { SIGNATURES } \\
\text { Financial Analyst: } \\
\text { CAM: }\end{array}$ & & - & $\begin{array}{l}\text { Date: } \\
\text { Date: }\end{array}$ & & BASELINE & PROVAL & & & Tate: \\
\hline
\end{tabular}




\subsection{Appendix C General Purpose Facilities}





\section{CONTENTS}

6.3 APPENDIX C - GENERAL PURPOSE FACILITIES [WBS 6.8.3] . . . . C-1

6.3.1 Mission/Vision . . . . . . . . . . . . . . C-1

6.3.1.1 Performance Measures $\ldots \ldots \ldots \ldots \ldots \ldots \ldots$. . . . .

6.3.2 Government Buildings [WBS 6.8.3.1] . . . . . . . . C-4

6.3.2.1 Mission/Vision . . . . . . . . . . . . . C-4

6.3.2.2 Goals and Objectives . . . . . . . . . . . C-4

6.3.2.3 Activities Performed ................ C-5

6.3.2.4 Assumptions and Constraints . . . . . . . . . C-8

6.3.2.5 Regulatory Requirements . . . . . . . . . . . . C-9

6.3.3 Leased Buildings $[6.8 .3 .2] \ldots \ldots \ldots \ldots \ldots \ldots \ldots \ldots . . . . . .12$

6.3.3.1 Mission/Vision . . . . . . . . . . . . . C-12

6.3.3.2 Goals and Objectives $\ldots \ldots \ldots \ldots \ldots \ldots \ldots \ldots$. . 12

6.3.3.3 Activities Performed . . . . . . . . . . . . C-12

6.3.3.4 Assumptions and Constraints . . . . . . . . . C-12

6.3.3.5 Regulatory Requirements . . . . . . . . . . . . C-13

6.3.4 Roads and Grounds [WBS 6.8.3.3] . . . . . . . . . C-15

6.3.4.1 Mission/Vision . . . . . . . . . . . . C-15

6.3.4.2 Goals and Objectives ................

6.3.4.3 Activities Performed .................

6.3.4.4 Assumptions and Constraints . . . . . . . . . C-16

6.3.4.5 Regulatory Requirements . . . . . . . . . . C-16

LIST OF TABLES

C-1 Milestone Description Sheet $\ldots \ldots \ldots \ldots \ldots \ldots \ldots \ldots \ldots$ C-3

C-2 WBS Dictionary $\ldots \ldots \ldots \ldots \ldots \ldots \ldots \ldots \ldots \ldots \ldots \ldots \ldots \ldots \ldots \ldots \ldots$

C-3 WBS Dictionary $\ldots \ldots \ldots \ldots \ldots \ldots \ldots \ldots \ldots \ldots \ldots \ldots \ldots \ldots \ldots \ldots \ldots$

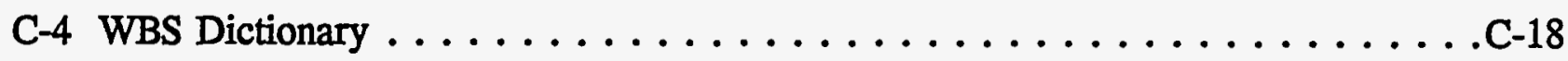





\subsection{APPENDIX C - GENERAL PURPOSE FACILITIES [WBS 6.8.3]}

\subsubsection{Mission/Vision}

General Purpose Facilities provides safe operation and maintenance of facilities which include office, shops, laboratories and warehouses. Roads and grounds upkeep is provided within the 200,300, 400,600, 700, 1100 and 3000 Areas in support of the Hanford Site mission.

The vision is to strive to move forward in all program elements to be recognized as responsive to Site needs. Actions required to achieve this vision are:

- Emphasize safety in the operation and maintenance of assigned facilities and systems.

- Provide safe and occupiable general purpose facilities to support accomplishment of the Hanford Site mission.

- Strive to understand customers' changing needs and contractor responsibilities to ensure uninterrupted support of the Hanford Site mission.

- Maintain performance measurement techniques.

\subsubsection{Performance Measures.}

Objective: Effectively manage the work activities within our facilities.

- Goal \#1: Achieve a site space utilization rate of 135 square feet per person. Performance Measure: Show an overall utilization rate of 135 square feet per person in general purpose facilities based on the force report and net square feet billed on a monthly basis.

- Goal \#2: Achieve a custodial service rate of 30,000 square feet per person.

Performance Measure: Show an overall service rate of 30,000 square feet per person based on full time equivalents divided by square footage serviced.

- Goal \#3: Vacate and place in standby condition 12 buildings.

Performance Measure: Implement 12 shutdown plans by September 30, 1996. 
- Goal \#4: Implement building shutdown plan actions within 14 days of vacating facility.

Performance Measure: Track number of days vacant against plan acceptance date (by facility manager).

- Goal \#5: Achieve an annual Management Effectiveness Indicator (MEI) of 70\%.

Performance Measure: Trend our management effectiveness by using the MEI. A control chart shall be used to determine the trend and upper/lower control limits for this process.

- Goal \#6: Continue to reduce unfunded and unnecessary work requests.

Performance Measure: Track and plot the total number of work requests received versus the number of work requests denied.

- Goal \#7: Maintain or reduce the level of corrective maintenance work requests received and recorded.

Performance Measure: Track and plot on a monthly basis the number of new corrective maintenance requests. Constant or declining trends provide evidence of an effective preventive maintenance program.

- Goal \#8: Develop a cost tracking model versus work performed for actual maintenance cost.

Performance Measure: Complete development in the first quarter of FY 1996 and begin reporting actual cost per maintenance job by the beginning of the 2nd quarter of FY 1996. 
Table C-1. Milestone Description Sheet.

\begin{tabular}{|c|c|c|c|}
\hline \multicolumn{3}{|c|}{ Title: Leased Property Report } & $\begin{array}{r}\text { Date Prepared: } \\
09 / 26 / 95 \\
\end{array}$ \\
\hline \multicolumn{3}{|c|}{ Assigned To: Leased Buildings } & CIN: \\
\hline \multicolumn{3}{|c|}{ WBS Designator: 6 -8.3.2 } & $\begin{array}{l}\text { Due Date: } 10 / 31 / 95 \\
04 / 29 / 96\end{array}$ \\
\hline \multicolumn{3}{|c|}{ Control Number: SSP-96-C01 } & Revision: \\
\hline $\begin{array}{l}\text { Milestone Type: } \\
\square \text { DOE-HQ } \\
\square \text { DOE-RL } \\
\square \text { CNTR }\end{array}$ & $\begin{array}{l}\text { Division: } \\
\square \text { State } \\
\square \text { Federal } \\
\square \text { DOE } \\
\square \text { RCRA } \\
\square \\
\text { TPA\# }\end{array}$ & $\begin{array}{l}\text { Deliverable: } \\
\square \text { Report } \\
\square \text { Letter } \\
\square \text { Drawings } \\
\square \text { Other } \\
\text { (specify) }\end{array}$ & $\begin{array}{l}\text { Address To: } \\
\square \text { DOE-HQ } \\
\square \text { DOE-RI } \\
\square \text { Other } \\
\text { (specify) }\end{array}$ \\
\hline
\end{tabular}

Milestone Description

Develop a Lease Property Report and transmit to DOE-RI.

Description of what constitutes completion of this milestone:

Transmittal of report to RL.

Cost Account Managef,

R. C. Funderburg

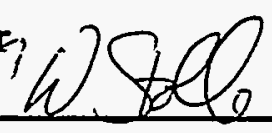

Program Element Manager

L. M. Kinsey $f(1)$.

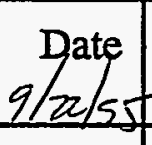

Date
Program/Project Mzhrger/ G. A. Harvey

DOE Monitor 


\subsubsection{Government Buildings [WBS 6.8.3.1]}

6.3.2.1 Mission/Vision. The mission is to provide for the management of government owned real property to its intended use, coordinate assignment and configuration of general purpose space, provide maintenance upgrades and building modifications, develop planning and analyses to facilitate optimum use of existing and future facilities. Support space and organization relocation planning, proper space utilization, building activation and deactivation, building modifications, design preparation (building, equipment and furniture layout), and personnel relocations for all Site contractors. Establish and maintain building vacancy plan. Provide building management for all general purpose facilities and oversight/ approval prior to maintenance activities.

Perform minimum maintenance, both corrective and preventive, for all general purpose facilities. Maintain aging facilities at minimum levels. Provide custodial services for all general purpose facilities.

\subsubsection{Goals and Objectives.}

- Place special emphasis on safety while complying with applicable DOE orders and federal and state regulations.

- Conduct work in strict compliance to established procedures.

- Support the DOE and its contractors in the acquisition and/or disposal of office space.

- Meet occupant office space requirements in mobile and real property facilities.

- Base decisions for repair versus replace on the future needs of individual facilities.

- Meet all applicable environmental state and federal requirements.

- Act as the contractor focal point for supporting the DOE in office space activities and administration.

- Plan, integrate, and approve assignment of space, including leased buildings and other Hanford Site buildings occupied by contractor personnel.

- Develop building use plans and provide facility evaluations/studies to support operational and long-range planning documents.

- Manage building use for all Site facilities.

- Make personnel relocations for general purpose facilities more cost effective. 
- Review and annotate all general purpose facilities office furniture and furnishings, store orders, and requisitions, assessing them for need to assist management in determining the appropriate furnishings to order and to redeploy existing excess.

- Provide building management for all general purpose facilities.

- Develop vacate lists/plans for general purpose facilities; assist in decontamination and decommissioning plans, as well as area/building excessing.

- Vacate government facilities and inadequate leased facilities by consolidating into more habitable facilities.

\subsubsection{Activities Performed.}

\subsection{Funded Activities.}

- Provide site management for facilities and custodial services.

- Provide short range planning to include development of vacate plans for general purpose facilities and recommendations for acquisition and disposal of facilities.

- Manage space use for all general purpose facilities, provide direction to vacate general purpose facilities, point of contact for monitoring and adjustment of building/space use to support asset management, review and approve space/ relocation justification and building modifications, provide building layouts/ AutoCad support for space justification, support personnel relocations, provide building management for all facilities.

- Provide administration of mobile office facilities including inventory and oversight. Provide, maintain, and update mobile trailer records; and assist in buyouts and/or excessing.

- Provide custodial services and management direction for all general purpose facilities in the $200,300,400,600,700$ and 1100 Areas. Provide engineering support to custodial services for procedure development, procurement, administrative support and hazardous material support. Custodial support to include emptying trash, cleaning restrooms, general cleaning, and strip and wax floors. Environmental support (i.e., reports, audit support, investigations, and guidance).

- Perform review of maintenance work packages. Review requests against vacate plan, review and control maintenance costs in general purpose facilities, and set priorities for maintenance based on safety and protection of government assets. 
- Provide corrective maintenance (40 percent) for failed equipment/systems, structural defects, and restoration to design conditions for safety related issues only as supported by the Annual Work Plan.

- Perform preventive maintenance (55 percent) for routine services. Examples include filter, belt replacements, and lubrications, system tests and/or calibrations, scheduled replacement or change-out, freeze protection plans, cold weather checklists/excursions, building surveillances, winterization preparation/ maintenance, systems repairs, and third party inspections as supported by the . Annual Work Plan.

- Provide predictive maintenance (5 percent) - oil/vibration analysis, infra-red imaging, and maintenance trending.

- Provide work management activities including planning, work release, plan of the day/plan of the week (POD/POW), scheduling, equipment history, reporting, record keeping, ad hoc reports, performance measures for critical equipment only, audits, plant forces work review (PFWR), maintenance engineering, design engineering, and quality assurance.

- Perform material purchasing support for measuring and test equipment, spare parts, inventory control, and budgeting.

- Provide building engineering to include design authority management and interface with subcontractors, work management, emergency response, surveillance, work release, energy control, lock and tag, configuration control, permits, coordination, and operating system line-up.

- Provide building management for all general purpose facilities. Management includes budgets, building emergency organizations/plans, radiological safety resolutions, employee concerns, facility inspections/reporting, fire watch, utilities support, and pest control.

- Perform hazardous waste management for satellite areas, 90 day pads, Resource Conservation and Recovery Act (RCRA) compliance inspections, ecology inspections, spills, Emergency Planning and Community Right-to-Know Act (EPCRA) reporting, radiological/hazardous waste clean-up, orphan drums, legacy waste, underground tanks, orphan buildings, coordination of inspections/audits/ tours and health physics technician support.

- Perform asbestos/lead activities to include air monitoring, removal, replacement, abatement, surveillance, assessment, and sampling.

- Provide facility operations. Examples include air balance, facility surveillance, energy control, lock and tag, system configuration control, building security checks, and cold weather excursions. 
- Perform roof assessment/inspections including follow-up maintenance, report preparation and management, contract management, administration, and coordination of annual assessments/inspections.

- Provide skills/facility training including mandatory, maintain records, administration, certifications (e.g., licensed electricians, backflow provender, air conditioner ozone depleting substances, commercial drivers license, apprenticeship program), design engineering change notices, root cause analysis, and mandatory training matrix.

- Perform personnel management including administration of labor agreements, stewards, grievances, labor relations, employee concerns, appraisals, salary planning, career development, and Equal Employment Opportunity/Affirmative Action Program (EEO/AAP).

- Provide building administration to include building coordination, maintenance coordination, budgeting, HLAN and telephone coordination, building/area security, locks, access control, infractions, key control, fencing, and signage.

- Provide planning and forecast support for site support program plan, annual work plans, manpower projections, baseline changes, Site Management System, monthly/weekly/annual reports, award fee, performance measurements, Hanford Action Tracking System, scope definition, change control, budget control, appropriations, and planning.

\subsection{Unfunded Activities.}

- Maintenance support to provide sufficient levels of support for corrective, preventive and predictive maintenance.

- Maintenance of the Computerized Maintenance Management System (CMMS) will not be performed resulting in the lack of reporting capabilities and forecasting performance measures. This results in a loss of control to configuration management as the CMMS provides the bridge between work management and drawing updates.

- Transition of facilities to decontamination and decommissioning affects the ability to maintain vacant and vintage buildings at acceptable levels based on current budget/headcount levels. Site impacts will occur due to the inability to maintain vacant buildings awaiting decontamination and decommissioning.

- Materials (e.g., safety tools and equipment) will restrict the replacement of safety related handtools and equipment such as safety glasses, leather gloves, and hard hats. The unavailability of protective equipment may result in unnecessary exposure of maintenance personnel to unsafe conditions. 
- Reduced building engineering will result in the inability to provide effective work package development, lock and tag, and event reporting. Customer interface will be negatively impacted as the communication between groups becomes restricted. Response times to facility hazard checklists, audit findings, managerial requests and safety walkdowns, may be delayed. The scheduling of work packages and customer interface may be delayed.

- Reductions in Asbestos/Lead activities will impact the ability to support the Hanford Site Asbestos Abatement Plan, WHC-EP-0290. The inability may subject facility personnel to potential exposure to friable asbestos insulation. Asbestos sampling will be postponed and removal for repairs delayed. The lead abatement program will not receive the required attention to abate at the necessary levels to avoid overexposure.

- Reduced training may result in delinquent company and state certifications/qualifications. The inability to maintain this level of expertise will reduce the availability of qualified personnel.

- Cancellation of the As-building program may result in National Electrical Code (NEC) violations which will remain unidentified and corrected. The inability to provide lock and tag identification for isolation of equipment and components may result in the compromise of worker safety.

\subsection{Related Activities.}

- Landlord Program provides for expense related construction, demolition and construction related maintenance. Included in this activity are such things as roof replacements, corrective maintenance of a construction nature, facility modifications, abandoned facility demolition and land maintenance. Refer to Landlord Program WBS element 7.5.2 (Expense Funded Projects) for further details.

- Landlord Program provides for capital equipment. Included in this activity are such things as shop equipment (e.g., dust collection systems, lead detection equipment), HVAC upgrades and capital computing equipment. Refer to Landlord WBS element 7.5.3 (Capital Equipment) for further details.

\subsubsection{Assumptions and Constraints.}

\subsection{Assumptions.}

- Funding will be provided to ensure compliance with all applicable state and Federal regulations.

- Funding is not included for emergency type repairs and emergency response. 
- Funding from the Landlord Program will remain at current levels for expense funded projects in FY 1996.

- As population reductions progress consolidation of facilities will continue.

- Funding of an accelerated shutdown/standby condition will be required in FY 1996 and FY 1997.

- Site support service costs will increase as requirements for clean up increase.

- Buildings requirements will generally decrease from FY 1995 levels based upon the following. In FY 1995, an aggressive effort began, with workforce reductions, to consolidate office space occupancy into the more efficient facilities. That effort will continue in FY 1996, along with efforts to consolidate shop and warehouse activities as well. In addition, some of the vacated facilities will be demolished or excessed in FY 1996.

\subsection{Constraints.}

- Occupancy of inadequate space will drive additional maintenance expenditures to keep poor facilities in a safe working condition. Vacating these inadequate facilities should eliminate some safety concerns and costly maintenance issues.

- Facilities will continue to deteriorate due to reduced maintenance budget. Failure to fund the maintenance program will increase out-year maintenance costs.

- Funding by customers is limited or does not exist for personnel moves. Telecommunications and furniture also create major concerns. Customers identified for moves are typically not in a position to fund the costs associated with occupying new space.

- Lack of a universal computer data base for facilities management/space use that will interface with other on Site systems, e.g., Maximo, FDS, PeopleCore, etc.

\subsubsection{Regulatory Requirements.}

DOE 4320.2A, "Site Development and Facility Utilization Planning"

DOE 4300.1C, "Real Property Management"

DOE 4330.4B, "Maintenance Management Program"

DOE 5480.1B, "Environmental, Safety, and Health Program for Department of Energy Operations" 
Resource Conservation and Recovery Act of 1976

Clean Air Act

Clean Water Act

Environmental Protection Agency

Occupational Safety and Health Administration

29 CFR 1910.1030, Occupational Health and Safety Administration, Blood Borne Pathogens

29. CFR 1904, Recording and Reporting Occupational Injuries and Illnesses

40 CFR 265, Interim Status Standards for Owners and Operators of Hazardous Waste Treatment, Storage and Disposal Facilities

40 CFR 372, Toxic Chemical Release Reporting: Community Right to Know

Washington Administrative Code (WAC) 173, Ecology, Department of

WAC 146, Department of Health

WAC 296, Labor and Industries, Department of 


\section{Work}

Breakdown

Structure

Dictionary

\section{Cost Account Number}

$1 \mathrm{MDH}$

SMS WBS Number

RL SMS Program Manger

Cost Account Manager

WHC SMS Program Manager

Financial Manager:

\begin{tabular}{r|l}
\hline Responsible Analyst : & MH LAWRENCE \\
\hline FY 1996
\end{tabular}

\section{TYPE OF FTE}

Organizational

Support

$\stackrel{9}{a}$

TOTALFTES

SMS Title

CL STICE
6.8.3.1

\section{Westinghouse Hanford Company GOVERNMENT BUILDINGS \\ Part I - Summary}

(Dollars in 000's)

Cost Account Title OCCUPANCY POOL

GOVERNMENT BUILDINGS

RC FUNDERBURG

RC FUNDERBURG

MH LAWRENCE

FY 1996 Approved Funding

Full-Time Equivalents (FTEs)

\begin{tabular}{|r|r|r|r|r|r|r|r|r|}
\hline Exempt & Non-Exempt & Bargaining & Exempt & Non-Exempt & Bargaining & Exempt & Non-Exempt & Bargaining \\
\hline 58.2 & 15.5 & 91.5 & 4.3 & & 6.0 & 62.5 & 15.5 & 97.5 \\
\hline 10.0 & 3.2 & 4.6 & & & & 10.0 & 3.2 & 4.6 \\
\hline
\end{tabular}

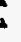

COST ELEMENTS

- Labor - Regular

- Labor - Overtime

0 Total Labor

1 Materials

2 Purchased Services

3 Other Hanford

Subtotal ofigh inated costs.

4 Site Services

5 Internal Charges

6 IRM Support

7 Overheads

8 Revenue

TOTAL DOLLARS
18.7

96.1
FY 1996

Indirect

Program Plan

Rev. \# 1

25-Sep-95

Proposed Rate:

(Rated Service Pool Only)

G\&A

SWS

OST

DOH

MGT PRO

POOLL

\section{Funding Source:}

6.0

4.3

72.5

18.7

102.1

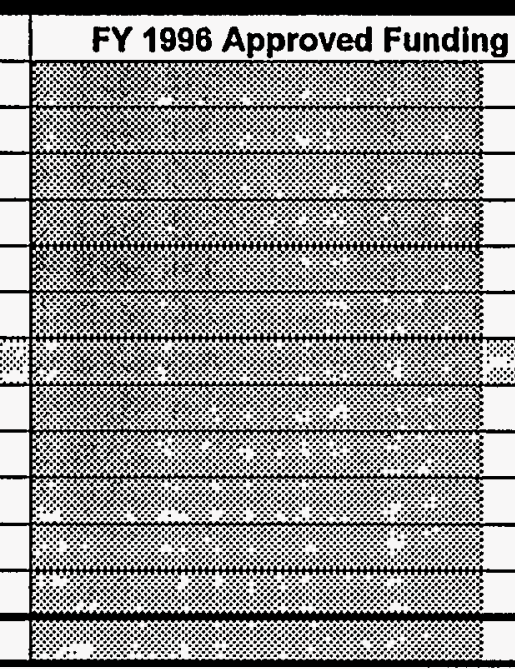

ing Budget

$10,861.3$

FY 1996 Unfunded Budget

110.8

$10,972.1$

$1,215.6$

922.0

316.5

२13.426.2

$10,572.8$

$1,298.8$

145.9

$5,677.5$

$31,121.2$
00.3

FY 1996 Baseline Budget

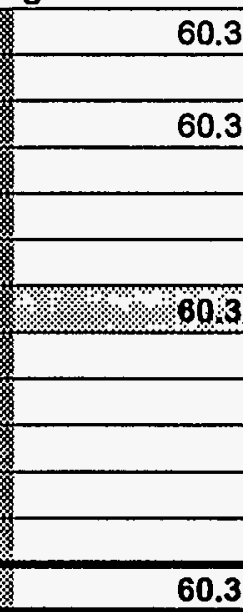

\section{SIGNATURES *}

Financial Analyst: CAM:

Date: Date: 


\subsubsection{Leased Buildings [6.8.3.2]}

6.3.3.1 Mission/Vision. The mission is to provide for the management of leased facilities, coordinate assignment and configuration of space, develop planning and analyses to facilitate optimum use of existing and future facilities.

\subsubsection{Goals and Objectives.}

- Emphasis on safety while complying with applicable DOE Orders and federal and state regulations.

- Support the DOE and its contractors in the acquisition and/or disposal of office space.

- Meet occupant office space requirements in mobile and real property facilities.

- Act as the contractor focal point for supporting the DOE in office space activities and administration.

- Provide building management for all general purpose facilities.

- Vacate government facilities and inadequate leased facilities before consolidating into more habitable facilities.

\subsubsection{Activities Performed.}

6.3.3.3.1 Funded Activities.

- Provide services, expertise, and funding for acquisition, management, disposal, and reporting of commercial and inter-contractor leased space. Provide oversight of major modifications to leased facilities. Serve as RL contractor point of contact for General Services Administration (GSA) leased facilities. Provide real estate expertise to various organizations as required.

\subsection{Related Activities.}

- Landlord Program provides for capital equipment. Included in this activity are buy out of mobile office leases. Refer to Landlord WBS element 7.5.3 (Capital Equipment) for further details.

\subsubsection{Assumptions and Constraints.}

\subsection{Assumptions.}

- As population reductions progress consolidation of facilities will continue. 
- Buildings requirements will generally decrease from FY 1995 levels based upon the following. In FY 1995, an aggressive effort began, with workforce reductions, to consolidate office space occupancy into the more efficient facilities.

\subsection{Constraints.}

- Funding by customers is limited or does not exist for personnel moves. Telecommunications and furniture also create major concerns. Customers identified for moves are typically not in a position to fund the costs associated with occupying new space.

\subsubsection{Regulatory Requirements.}

DOE 2200.5B, "Fund Accounting"

DOE 4300.1C, "Real Property Management"

DOE 4330.2C, "In-House Energy Management"

DOE 6430.1A, "General Design Criteria"

Federal Acquisition Regulation (FAR) 31.205-36 


\section{Work \\ Breakdown \\ Structure \\ Dictionary}

Cost Account Number

$1 \mathrm{MDHOD}$

SMS WBS Number

6.8.3.2

RL SMS Program Manger

Cost Account Manager

WHC SMS Program Manager

Financial Manager:

Responsible Analyst:

TYPE OF FTE

Organizational

Support

$\frac{P}{P}$

TOTAL FTES

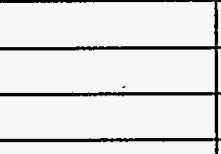

COST ELEMENTS

. Labor - Regular

. Labor - Overtime

O Total Labor

1 Materials

2 Purchased Services

3 Other Hanford

Subtotal Origlnated Costs

4 Site Services

5 Internal Charges

6 IRM Support

7 Overheads

8 Revenue

TOTAL DOLLARS

\section{Westinghouse Hanford Company}

LEASED BUILDINGS

Part I - Summary

(Dollars in 000's)

Cost Account Title

LEASINGIADMINISTRATION

SMS Title

LEASED BUILDINGS

RC FUNDERBURG

RC FUNDERBURG

CL STICE

MH LAWRENCE

FY 1996 Approved Funding

Full-Time Equivalents (FTEs)

\begin{tabular}{|r|r|r|l|l|l|}
\hline Exempt & Non-Exempt & Bargaining & Exempt & Non-Exempt & Bargaining \\
\hline 2.0 & 0.3 & & & & \\
\hline 2.0 & & & & & \\
\hline
\end{tabular}

$+$

FY 1996 Approved Funding

ing Budget

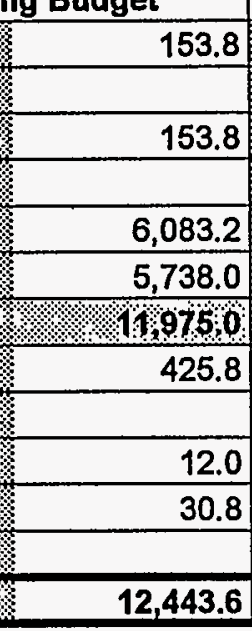

SIGNATURES

Financial Analyst:

Date:

Date:

FY 1996

Indirect

Program Plan

Rev.\# 1

25-Sep-95

Proposed Rate:

(Rated Service Pool Only)

G\&A

SWS

OST

DOH

MGT PRO

RoOL

Funding Source:

FY 1996 Baseline

Full-Time Equivalents (FTEs)

Exempt $\quad$ Non-Exempt $\quad$ Bargaining

\begin{tabular}{|r|r|}
\hline 2.0 & 0.3 \\
\hline & \\
\hline 2.0 & 0.3 \\
\hline
\end{tabular}

CAM:
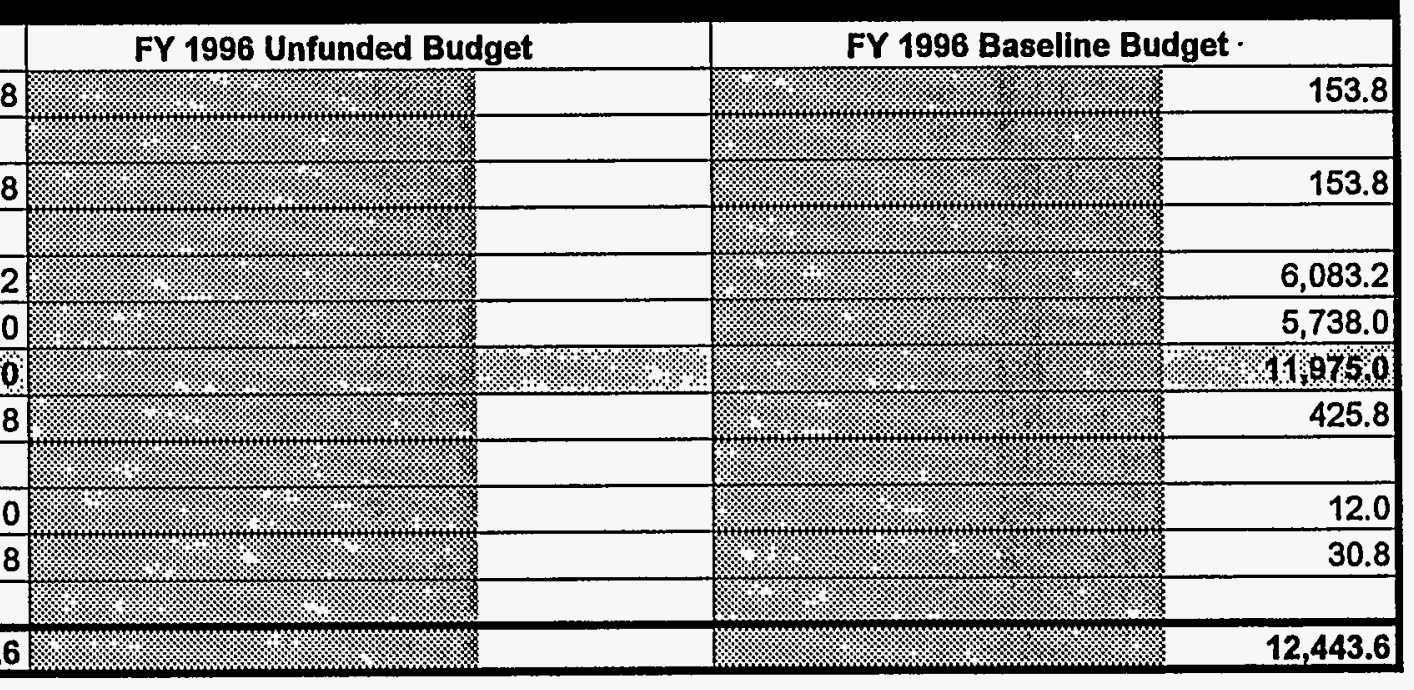

BASELINE APPROVAL

Date: 


\subsubsection{Roads and Grounds [WBS 6.8.3.3]}

6.3.4.1 Mission/Vision. The mission is to provide road and grounds maintenance within the $200,300,400,600,700,1100$ and 3000 Areas. This includes road, sidewalk, and parking lot repairs, snow removal, weed control, tumbleweed removal, fence repairs, and general area cleanup.

\subsubsection{Goals and Objectives.}

- Place special emphasis on safety while complying with applicable DOE orders and federal and state regulations.

- Conduct work in strict compliance with procedures.

\subsubsection{Activities Performed.}

\subsection{Funded Activities.}

- Maintain roads, sidewalks, and parking lots to include inspection, repairs, stripe roads, sweep roads, maintain signs, and debris removal.

- Provide general area clean-up, such as, lawn care including the 300 Area catch basin and tumbleweed removal.

- Provide weed control and removal and perform herbicide application.

- Perform radiological surveillances.

- Provide surveillance and repair of perimeter fences.

- Remove snow and sand from roads, sidewalks, and parking lots.

- Provide emergency response support for range fires or spill containment and control.

\subsection{Unfunded Activities.}

- Reduced roads and grounds funding will impact the ability to provide snow removal, tumbleweed clean up, road repairs within the 200 Area, signage, general area clean up and hazardous waste hauling. Snow removal will no longer take place prior to work commencement. There will be a degradation in emergency response to hazardous material spills and brush fires. Tour route clean up will be postponed. 
- Lack of lawn care for the 300 Area catch basin will result in failure to maintain the catch basin. This will result in non-compliance with Washington State Department of Transportation (DOT) regulations.

\subsection{Related Activities.}

- Roads and grounds maintenance for the general 600 Area Landlord activities are included in the Services WBS element 6.8.2.

\subsubsection{Assumptions and Constraints.}

\subsection{Assumptions.}

- Funding is not included for lawn care for the 300 Area catch basin. Failure to maintain the catch basin will result in non-compliance with State DOT regulations.

- Roads and Grounds requirements have not changed from FY 1995 levels. The amount of 200 and $\mathbf{3 0 0}$ Areas lawns, streets, parking lots, and sidewalks and the effort needed to maintain them is not expected to change in FY 1996. These requirements are expected to stay relatively constant for the next several years.

\subsection{Constraints.}

- Funding for snow removal, area clean-up, grounds maintenance and weed removal are at minimal levels. If a severe winter is encountered, additional funding will be required to perform this scope of work.

- Overtime is funded at minimum levels for snow removal or emergency response.

\subsubsection{Regulatory Requirements.}

DOE 4330.4B, "Maintenance Management Program"

Resource Conservation and Recovery Act of 1976

Clean Air Act

Clean Water Act

Environmental Protection Agency

Occupational Safety and Health Administration

29 CFR 1904, Recording and Reporting Occupational Injuries and Illnesses 
40 CFR 265, Interim Status Standards for Owners and Operators of Hazardous Waste Treatment, Storage and Disposal Facilities

40 CFR 372, Toxic Chemical Release Reporting: Community Right to Know

Washington Administrative Code (WAC) 173, Ecology, Department of

WAC 146, Department of Health

WAC 296, Labor and Industries, Department of 


\section{Work}

Breakdown

Structure

Dictionary

Cost Account Number

1MDAOK

SMS WBS Number

6.8.3.3

RL SMS Program Manger

Cost Account Manager

WHC SMS Program Manager

Financial Manager:

Responsible Analyst:

\section{TYPE OF FTE}

Organizational

Support

TOTAL FTES

COST ELEMENTS

. Labor-Regular

. Labor - Overtime

o Total Labor

1 Materials

2 Purchased Services

3 Other Hanford

Subtotal Oringinated $\mathrm{Costs}$

4 Site Services

5 Internal Charges

6 IRM Support

7 Overheads

8 Revenue

TOTAL DOLLARS

\section{SIGNATURES}

Financial Analyst:

Date:

CAM:

Cost Account Title

ROADS \& GROUNDS

SMS Title

ROADS \& GROUNDS

\section{WH HAYS}

WH HAYS

CL STICE

ME ANTONIO

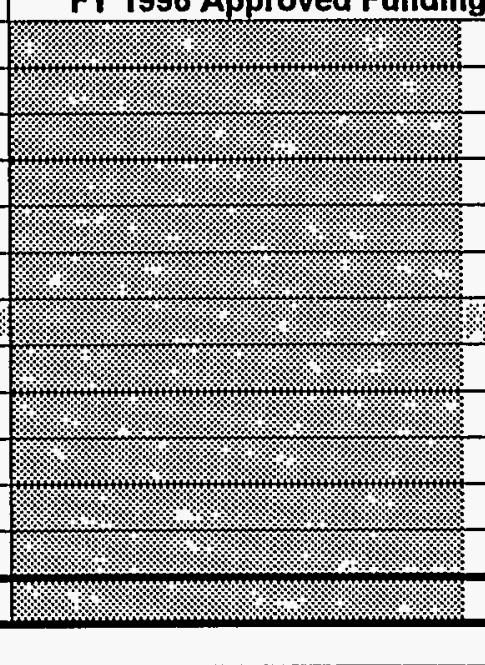

\section{Westinghouse Hanford Company}

ROADS \& GROUNDS

Part I - Summary

(Dollars in 000's)

FY 1996 Approved Funding

Full-Time Equivalents (FTEs)

\begin{tabular}{|r|r|r|l|l|l|}
\hline Exempt & Non-Exempt & Bargaining & Exempt & Non-Exempt & Bargaining \\
\hline 1.7 & & 5.0 & & & \\
\hline 0.7 & 0.8 & 1.7 & & & \\
\hline 2.4 & 0.8 & 6.7 & & & \\
\hline
\end{tabular}

\section{FY 1996 Approved Funding Budget}

ing Budget

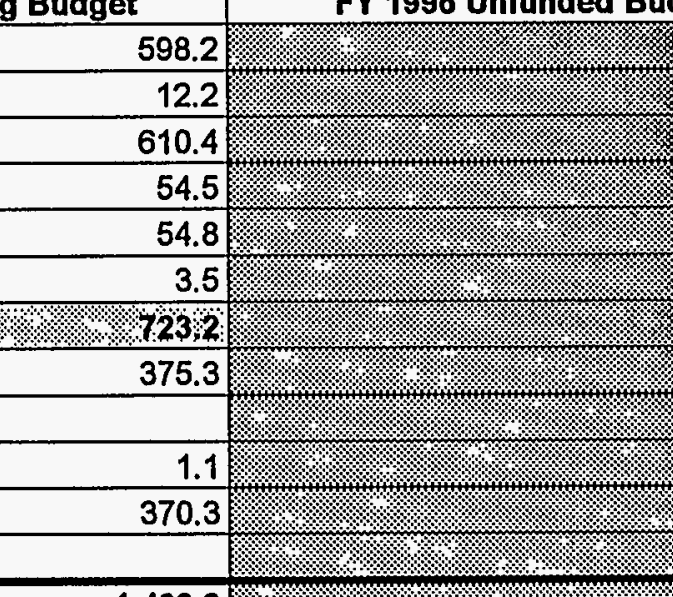

$1,469.9$ udget

FY 1996

Indirect

Program Plan

Rev. \# 1

25-Sep-95

Proposed Rate:

(Rated Service Pool Only)

Funding Source:

G\&A

SWS

OST

DOH

MGT PRO

POOL 2 XXX

FY 1996 Baseline

Full-Time Equivalents (FTEs)

\begin{tabular}{l|l|l} 
Exempt & Non-Exempt & Bargaining \\
\hline
\end{tabular}

\begin{tabular}{|c|c|c|}
\hline & & \\
\hline 1.7 & 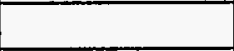 & 5.0 \\
\hline 0.7 & 0.8 & 1.7 \\
\hline 2.4 & 0.8 & 6.7 \\
\hline
\end{tabular}

17

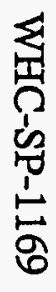

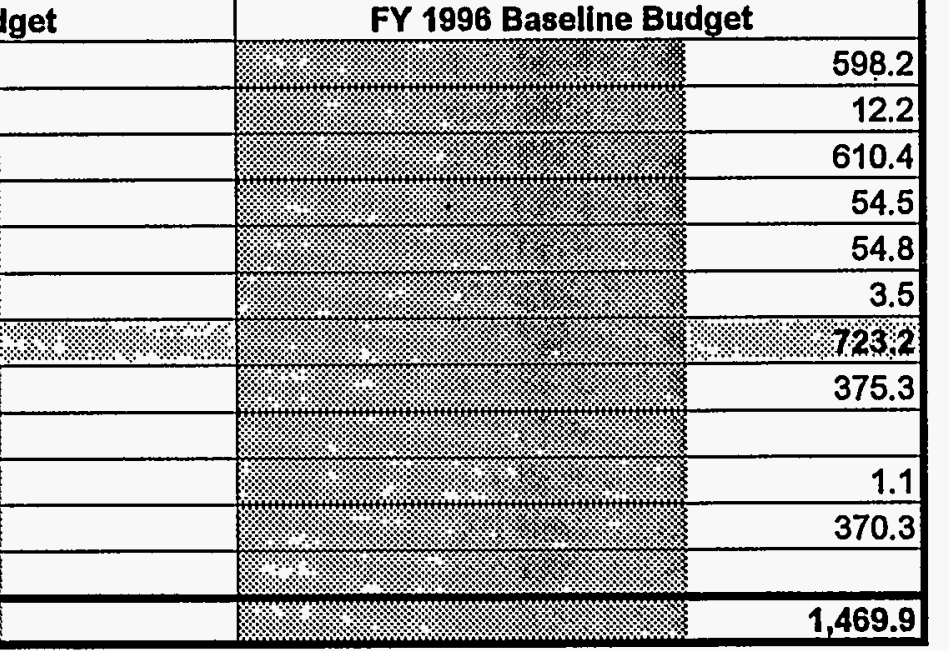

BASELINE APPROVAL

Date: 


\subsection{Appendix D Services}





\section{CONTENTS}

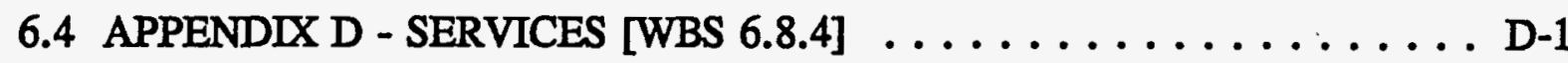

6.4 .1 Mission/Vision . . . . . . . . . . . . . . D-1

6.4.2 Crane and Rigging [WBS 6.8.4.1] $\ldots \ldots \ldots \ldots \ldots \ldots \ldots \ldots$ D-4

6.4.2.1 Mission/Vision ................ D-4

6.4.2.2 Goals and Objectives ............... D-4

6.4.2.3 Activities Performed ............... D-4

6.4.2.4 Assumptions and Constraints . . . . . . . . . D -5

6.4.2.5 Regulatory Requirements ............. D-5

6.4 .3 Fabrication [WBS 6.8.4.2] . . . . . . . . . . . . . D-7

6.4.3.1 Mission/Vision ................. . . .

6.4.3.2 Goals and Objectives . . . . . . . . . . D-7

6.4.3.3 Activities Performed . . . . . . . . . . . D-8

6.4.3.4 Assumptions and Constraints . . . . . . . . . . D-8

6.4.3.5 Regulatory Requirements . . . . . . . . . . . . D-9

6.4.4 Program Services [WBS 6.8.4.3] . . . . . . . . . . . D-11

6.4.4.1 Mission/Vision . . . . . . . . . . . D-11

6.4.4.2 Goals and Objectives . . . . . . . . . D-11

6.4.4.3 Activities Performed ............... D-11

6.4.4.4 Assumptions and Constraints . . . . . . . . . D-12

6.4.4.5 Regulatory Requirements . . . . . . . . . . D D-13

6.4.5 Laundry [WBS 6.8.4.4] . . . . . . . . . . . . D-15

6.4.5.1 Mission/Vision . . . . . . . . . . . . D-15

6.4.5.2 Goals and Objectives $\ldots \ldots \ldots \ldots \ldots \ldots$ D-15

6.4.5.3 Activities Performed . . . . . . . . . . D 15

6.4.5.4 Assumptions and Constraints . . . . . . . . . D-16

6.4.5.5 Regulatory Requirements . . . . . . . . . . D D-17

6.4.6 Environmental [WBS 6.8.4.5] . . . . . . . . . . . . . D-19

6.4.6.1 Mission/Vision . . . . . . . . . . . . . D-19

6.4.6.2 Goals and Objectives . . . . . . . . . . . D-19

6.4.6.3 Activities Performed . . . . . . . . . . . . . D-19

6.4.6.4 Assumptions and Constraints . . . . . . . . . . . D-19

6.4.6.5 Regulatory Requirements . . . . . . . . . D-20

6.4.7 Transportation Services [WBS 6.8.4.6] $\ldots \ldots \ldots \ldots \ldots \ldots$ D-22

6.4.7.1 Bus Operations ............... D-22

6.4.7.2 Courier and Moving Services ........... D-25

6.4.8 Technical Services [WBS 6.8.4.7] . . . . . . . . . . . . D-27

6.4.8.1 Mission/Vision . . . . . . . . . . . . . D-27

6.4.8.2 Goals and Objectives . . . . . . . . . . D-27

6.4.8.3 Activities Performed . . . . . . . . . . . . D-27

6.4.8.4 Assumptions and Constraints . . . . . . . . . . D-28

6.4.8.5 Regulatory Requirements . . . . . . . . . D -28 


\section{LIST OF TABLES}

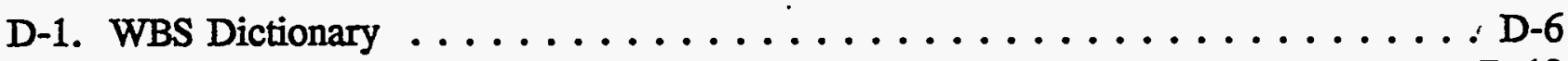

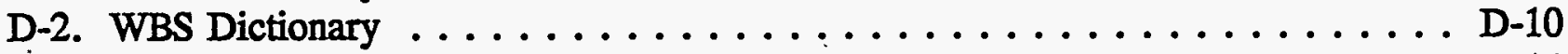

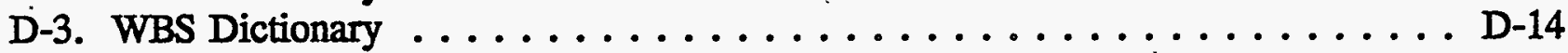

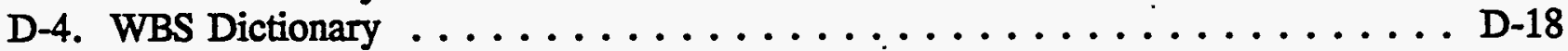

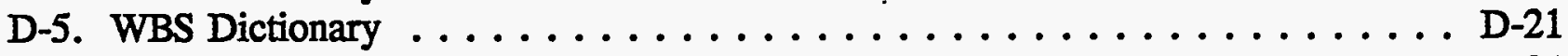

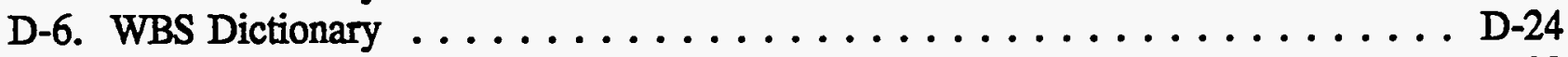

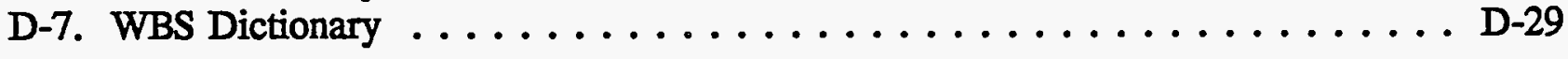




\subsection{APPENDIX D - SERVICES [WBS 6.8.4]}

6.4.1 Mission/Vision. The mission of the Services function is to provide direct-funded support to those components of the Hanford Site engaged in programmatic and support work activities supporting the Site clean-up mission.

Services are many faceted and play an important part in allowing programmatic activities to achieve the goals and milestones identified as critical to completing the Site clean-up mission. The support personnel and organizations are oriented toward efficient and structured support activities that emphasize meeting commitments, maintaining safety, and promoting customer programs.

The Services contained and discussed in this Appendix reflect the following types of support:

- Lifting, placement, and handling of large components in support of programmatic programs.

- Fabrication of one-of-a-kind and prototypic equipment and fabrication of components to support programmatic and emergency short-term needs required for critical area or program projects. Fabricate Safety Class I and II items.

- Corrective and preventive maintenance support for programmatic facilities, equipment, and/or systems for those activities not supported by a maintenance organization or for specialized craft needs not staffed because of limited need. Specialized road and grounds repairs and upkeep.

- Management of laundry activity including analysis of laundry needs, support of short-term emergency needs, direct dealing with laundry subcontractors, and analysis of levels of need.

- Technical-Services support for ongoing programs and projects.

- Transportation Services include courier service and personnel move support.

- Custodial support for programmatic facilities.

The services described and quantified in Appendix D are direct-funded. Manpower requirements are shown in full-time employees (FTEs). No associated dollar values are presented because funding resides within other program plans or in other sections of this program. 


\subsubsection{Performance Measures.}

\section{Program Services}

- Custodial performance: The amount of space serviced by each custodial person.

Measurement: Monthly plot of square feet serviced v.s. number of custodial personnel.

Goal: Increase square feet per person to greater than 30,000 by Oct 96 .

- Support to Facility Vacating Plan: Provide timely support to the vacating of government general purpose facilities.

Measurement: Monthly summary of vacated buildings indicating vacate date and date of implementation of shutdown plan actions.

Goal: Implement all shutdown actions for buildings vacated within 14 days of vacating the building.

\section{Crane and Rigging}

- Increased Budget Performance: Monitor performance and costs such that the FY-96 budget baseline will not be exceeded.

Measurement: A monthly plot of billing ratio and costs.

Goal: Maintain greater than 80 percent effectiveness rate for manhours worked.

\section{Fabrication Services}

- Customer Need Date Improvement: Increase the ability to meet or exceed customer job need dates.

Measurement: A plot summary indicating numbers of customers served and the percentage of met need dates on a monthly basis.

Goal: Meet customer need dates greater than 90 percent of the time.

\section{Technical Services}

- Customer Needs Assessment: Review customer needs against services offered to ensure valid services.

Measurement: Complete an assessment of selected ICF-KH organizations for applicable MAXIMO needs and compatibility. 
Goal: Complete assessment and review by March 1, 1996.

\section{Environmental Services}

- Reduction of 90 Day Storage Pads: Review reduction of 90 day storage pad actions.

Measurements: Using the 1995 Fiscal Year average number of 90 day storage pads as a base, plot monthly the number of 90 day storage pads in use in FY-96.

Goal: Reduce the number of 90 day storage pads 50 percent.

\section{Transportation Services}

- Taxi Cost per Ride: Maintain or reduce cost per ride for taxi service.

Measurement: Using generated data given on each ride determine the cost per ride basis by dividing total taxi cost by number of requests. Plot on a monthly basis.

Goal: Maintain cost per ride at or below FY-95 average value.

\section{Laundry}

- Reduce Laundry Costs: Reduce laundry costs by inovative measures, specifically, implement closed loop laundry service to customers.

Measurements: Reduce the overall laundry costs by reducing the number of replacement articles lost through previous waste. Measurement will be the dollar amount of replacement articles monthly compared to the average monthly replacement costs in FY-95.

Goal: Reduce monthly replacement costs by percent.

\section{All Service Groups}

Develop Annual Work Plans by October 1996. 


\subsubsection{Crane and Rigging [WBS 6.8.4.1]}

6.4.2.1 Mission/Vision. The mission of ICF Kaiser Hanford Company (ICF KH) Site Crane and Rigging Services (SC\&RS) is to support various programs dedicated to the maintenance, cleanup, and restoration of the Hanford Site. This support is provided through the lifting, handling, movement, and placement of material and equipment; inspection and maintenance of lifting equipment; erection, inspection, and removal of scaffold; fabrication, testing, and control of below-the-hook rigging equipment; and the management of mobile lifting equipment. All of this support is provided within the boundaries and scope of Westinghouse Hanford Company (WHC), ICF KH, or Hanford procedures, directives, and orders. The organization is dedicated to providing this support in the safest and most costeffective manner achievable.

A crane and rigging service that is out of the Hanford "box" is envisioned: a service that works to shed all but nationally recognized, commercial standards for assuring the safe, economical performance of work in a healthy and productive environment. Services that are being provided to a reengineered Hanford Site will achieve a level of excellence and costcompetitiveness with any provider of a similar service.

\subsubsection{Goals and Objectives.}

- Maintain low-risk and high demonstrated safety performance.

- Participate with other Hanford organizations in the management of reengineered equipment pool or pools.

- Provide crane service at a level competitive with offsite contractors.

- Separate equipment rate from the labor rate.

\subsubsection{Activities Performed.}

- Management and direction of the Site Crane and Rigging Services organization.

- Crane and Rigging support to Tank Waste Remediation Service and analytical laboratories. Provide equipment and labor as requested by the customer.

- Crane and Rigging support to Spent Nuclear Fuels (SNF) programs. Provide equipment and labor as requested by the customer.

- Crane and Rigging support to Solid Waste Disposal and T Plant. Provide equipment and labor as requested by the customer.

- Crane and Rigging support to Transition Projects (TP). Provide equipment and labor as requested by the customer. 
- Crane and Rigging support to the U.S. Department of Energy (DOE), ICF KH, WHC Central Stores, and Pacific Northwest Laboratory (PNL) activities. Provide equipment and labor as requested by the customer.

- Fabricate, test, and certify wire rope slings for Site contractors. Repair and replace load chain, wire rope slings for Site contractors.

- Establish and maintain a mobile crane pool.

\subsubsection{Assumptions and Constraints.}

6.4.2.4.1 Assumption. Based on feedback from customers, the level of support demanded of SC\&RS will be equal to or increased during FY 1996.

6.4.2.4.2 Constraint. If budget reductions are forthcoming within Hanford programs (our customers), and based on SC\&RS head count limitations, we may be constrained from supplying current levels of service.

\subsubsection{Regulatory Requirements.}

ICF KH SC\&RS operates under the Hanford Hoisting and Rigging manual

DOE-RL-92-36, ICF KH environmental safety and health manuals

American National Standards Institute (ANSI) standards for crane and rigging activities

29 Code of Federal Regulations (CFR) 1910, Occupational Safety and Health Administration (OSHA) standards

ICF KH and WHC administrative policies and procedures 


\section{Work \\ Breakdown \\ Structure \\ Dictionary}

Cost Account Number

SMS WBS Number

6.8.4.1

RL SMS Program Manager

Cost Account Manager

WHC SMS Program Manager

Financial Manager

Responsible Analyst

Responsible Analyst

\section{TYPE OF FTE}

Organizational

Support

是

TOTALFTES

\section{COST ELEMENTS}

. Labor - Regular

. Labor-Overtime

0 Total Labor

1 Materials

2 Purchased Services

3 Other Hanford

8 Revenue

Subtotaloriginated Costs

4 Site Services

5 Internal Charges

6 IRM Support

7 Overheads.

TOTAL DOLLARS

\section{SIGNATURES}

Financial Analyst:

CAM:
Westinghouse Hanford Company

Crane and Rigging Services

Part 1 - Summary

(Dollars in 000's)

\begin{tabular}{|c|c|c|c|c|c|}
\hline \multicolumn{6}{|c|}{$\begin{array}{l}\text { Cost Account Title } \\
\text { Crane and Rigging }\end{array}$} \\
\hline \multicolumn{6}{|c|}{$\begin{array}{l}\text { SMS Title } \\
\text { Crane and Rigging }\end{array}$} \\
\hline \multicolumn{6}{|c|}{ W.A. Rutherford } \\
\hline \multicolumn{6}{|l|}{ W.A. Ferree } \\
\hline \multicolumn{6}{|l|}{ G.A. Harvey } \\
\hline \multicolumn{6}{|l|}{ M.A. Davis } \\
\hline \multicolumn{6}{|l|}{ M.L. Van Liew } \\
\hline \multicolumn{3}{|c|}{$\begin{array}{c}\text { FY } 1996 \text { Approved Funding } \\
\text { Full-Time Equivalents (FTEs) }\end{array}$} & \multicolumn{3}{|c|}{$\begin{array}{l}\text { FY } 1996 \text { Unfunded } \\
\text { Full-Time Equivalents (FTEs) }\end{array}$} \\
\hline Exempt & Non-Exempt & Bargaining & Exempt & Non-Exempt & Bargaining \\
\hline 10.0 & 1.5 & 39.0 & & & \\
\hline 2.0 & & & & & \\
\hline 12.0 & 1.5 & 39.0 & 0.0 & 0.0 & 0.0 \\
\hline
\end{tabular}

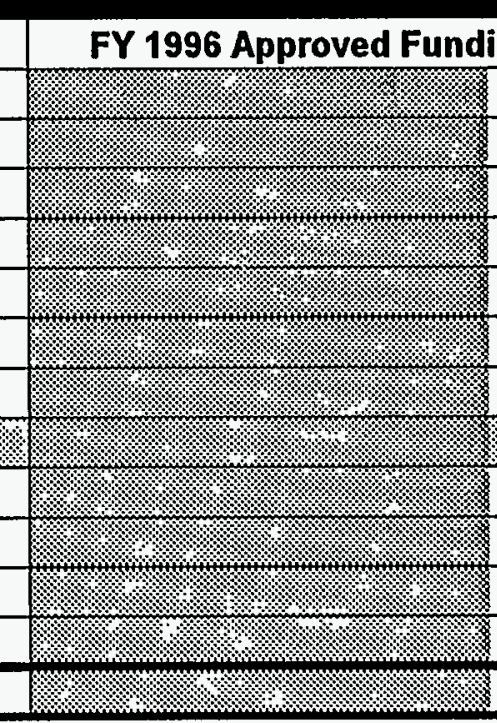

\section{ing Budget}

\begin{tabular}{|r|}
\hline $3,078.2$ \\
\hline 92.6 \\
\hline $3,170.8$ \\
\hline 181.0 \\
\hline 10.0 \\
\hline 0.0 \\
\hline 0.0 \\
\hline 3.361 .6 \\
\hline $1,354.1$ \\
\hline 418.1 \\
\hline 56.7 \\
\hline 75.7 \\
\hline $5,266.4$ \\
\hline
\end{tabular}

Date:

Date:

\begin{tabular}{|c|c|c|}
\hline \multicolumn{3}{|c|}{$\begin{array}{l}\text { Proposed Rate: } \\
\text { (Rated Service Pool Only) }\end{array}$} \\
\hline \multicolumn{3}{|c|}{ Funding Source: } \\
\hline \multicolumn{3}{|l|}{ sws } \\
\hline \multicolumn{3}{|l|}{ OST } \\
\hline \multicolumn{3}{|l|}{$\mathrm{DOH}$} \\
\hline \multicolumn{3}{|l|}{ MGT PRO } \\
\hline \multicolumn{3}{|l|}{ POOL $X$} \\
\hline \multicolumn{3}{|c|}{$\begin{array}{l}\text { 'FY } 1996 \text { Baseline } \\
\text { Full-Time Equivalents (FTEs) }\end{array}$} \\
\hline Exempt & Non-Exempt & Bargaining \\
\hline 10.0 & 1.5 & 39.0 \\
\hline 2.0 & 0.0 & 0.0 \\
\hline 12.0 & 1.5 & 39.0 \\
\hline
\end{tabular}

FY 1996

Indirect

Program Plan

Rev. \# 0

25-Sep-95

FY 1996 Unfunded Budget

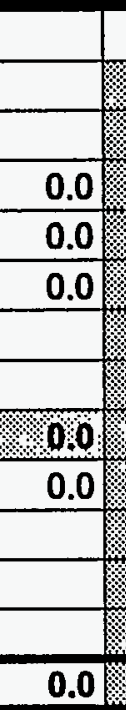

FY 1996 Baseline Budget

$3,078.2$

92.6

181.0

10.0

0.0

0.0

$1,354.1$

418.1

56.7

75.7

$5,266.4$
$3,361,8$

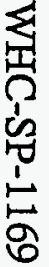$$
\overbrace{\substack{\alpha \\ 0}}^{0}
$$$$
\text { o }
$$

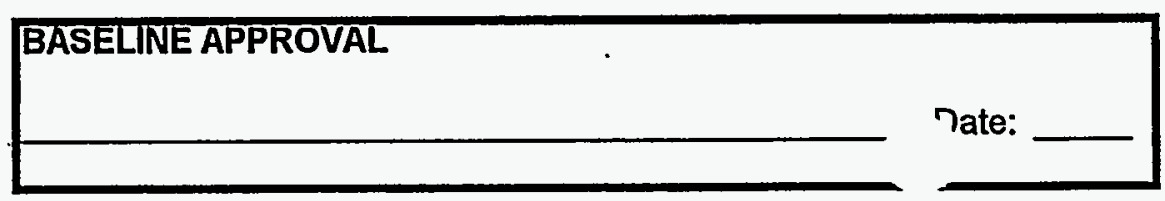




\subsubsection{Fabrication [WBS 6.8.4.2]}

6.4.3.1 Mission/Vision. The Site Fabrication Services (SFS) mission is to maintain a center of excellence with capability for the fabrication of prototype assemblies, repair of parts, components, and specified equipment repairs. Specific emphasis will be placed on prototypical and emergency work, which requires extensive engineering and manufacturing coordination. SFS will encourage a one-stop shopping center by maintaining a work brokering activity that will route and manage fabrication and manufacturing work to others onsite or offsite as required to support clean-up activities and schedules.

\subsubsection{Goals and Objectives.}

- Provide group safety motivation guidance to reduce lost work days and reduce restricted work days to or below those levels achieved by comparative commercial counterparts.

- Implement cost management tools to status and track total dollars expended, including support organizations and materials for each scope of work performed. This provides budgets for each fabricated item and a method to verify total dollars spent.

- Establish minimum and maximum material levels in the SFS shops to maintain critical items at a level so SFS can provide cost- and schedule-effective services without program delays. This includes investigation of offsite suppliers that maintain these materials and provide schedule-effective support.

- Provide visibility for cost and schedule collection systems to achieve the 90 percent schedule and budget goals that SFS has established. Results shall be indicated in performance measurements.

- Review design documentation before being issued to SFS so constructability and fabrication engineering can be conducted before release. This effort will ensure the customers' products and can be efficiently produced.

- Estimate and provide schedule impacts to our customers for changes issued to baseline designs before being issued to the shop floor. This will provide our customers with the effect of their change to product cost before incorporation into the fabrication.

- Encourage a one-stop shopping system that would allow customers to have a single point of contact when fabrication is needed. SFS would provide or obtain and manage all services necessary to support design, fabricate, inspect, and testfabricated items. 
- Assist in the development of a Site standard "Design Manual" to establish criteria that will result in fewer technical issues, resulting in improved cost and schedules.

- Reengineer the work management process, including package preparation, approval, reduction of unnecessary reviews, and elimination of no-value added steps.

- Establish the SFS-specific, in-house technical training requirements necessary to assure adequate job knowledge and safety training for each level of employee.

- Respond to requests from "work-for-others" that include offsite customers, and establish criteria to perform this work.

- Complete the transition from the WHC general-guidance procedures to general Level 4 procedures applicable to all customers.

- Consolidate SFS fabrication shops into the most effective space needed to support the Hanford and SFS missions.

- Assess current preventative maintenance activities and eliminate the redundant or unnecessary activities.

- Establish a system that will track labor and material costs when prototypical projects or extensive engineering support is required and firm estimates cannot be established.

6.4.3.3 Activities Performed. Fabrication in support of Safety Class 1 and 2 work, emergency orders, developmental control, and prototypical and fabrication projects requiring extensive engineering interface.

- Support services for programmatic customers.

- Fabrication support for modifications and testing of customer-procured items.

\subsubsection{Assumptions and Constraints.}

\subsection{Assumptions.}

- Level of support for the upcoming year will be equal to FY 1995. Based on historical information and verbal contact with customers, the current forecast of work will be consistent with projected resources.

- A forecasting system similar to that of ICF KH projects will be implemented in an effort to establish a baseline for the anticipated level of effort. 
6.4.3.4.2 Constraints. Customers are not always aware of internal technical and financial requirements for fabrication services. This can result in additional costs and fabrication delays. Education programs and process improvements for customers in preparing requests, funding, and internal technical requirements will reduce fabrication costs and improve schedule effectiveness.

In order to improve the current cost accounting methods, ICF KH will establish a policy that can allow costs for a specified scope of work to be collected. This system will collect total costs for fabrication, including all support functions and materials. Work requests given to SFS for fabrication will have a specified scope of work and an authorized dollar amount. The result will be a total fabrication cost compared to the customers' authorized budget.

6.4.3.5 Regulatory Requirements. SFS performs work to many codes, standard and top-tier requirements that include:

- DOE Order 5700.6c

- CFR 830.120

- American Society of Mechanical Engineers (ASME)/ANSI NQA-1

- 10 CFR 1021

- 40 CFR 1500-15089

- Secretary of Energy Notice $15-90$

- DOE Order 544.1e

Sub-tier requirements include the implementing policies, procedures, and programs that are driven by upper-level documents. The sub-tier implementing documents are included in both the ICF KH and WHC controlled manuals. 


\begin{tabular}{|c|c|c|c|c|c|c|c|c|c|}
\hline $\begin{array}{l}\text { Work } \\
\text { Breakdown } \\
\text { Structure } \\
\text { Dictionary }\end{array}$ & \multicolumn{6}{|c|}{$\begin{array}{l}\text { Westinghouse Hanford Company } \\
\text { Fabrication Services Direct Labor } \\
\text { Part } 1 \text { - Summary } \\
\text { (Dollars in 000's) }\end{array}$} & & \multicolumn{2}{|c|}{$\begin{array}{l}\text { FY } 1996 \\
\text { Indirect } \\
\text { Program Plan } \\
\text { Rev.\# } 0 \\
25-\text { Sep-95 }\end{array}$} \\
\hline Cost Account Number & \multicolumn{6}{|c|}{$\begin{array}{l}\text { Cost Account Title } \\
\text { Fabrication Services Direct Labor }\end{array}$} & \multicolumn{3}{|c|}{$\begin{array}{l}\text { Proposed Rate: } \\
\text { (Rated Service Pool Only) }\end{array}$} \\
\hline $\begin{array}{l}\text { SMS WBS Number } \\
\text { 6.8.4.2 }\end{array}$ & \multicolumn{6}{|c|}{$\begin{array}{l}\text { SMS Title } \\
\text { Fabrication Services Direct Labor }\end{array}$} & \multicolumn{3}{|c|}{ Funding Source: } \\
\hline RL SMS Program Manager & \multicolumn{6}{|c|}{ W.A. Rutherford } & \multicolumn{3}{|l|}{ sws } \\
\hline Cost Account Manager & \multicolumn{6}{|c|}{ W.A. Butterworth } & \multicolumn{3}{|l|}{ OST } \\
\hline WHC SMS Program Manager & \multicolumn{6}{|l|}{ G.A. Harvey } & \\
\hline Financial Manager & \multicolumn{6}{|l|}{ M.A. Davis } & \multicolumn{3}{|l|}{ MGT PRO } \\
\hline Responsible Analyst & \multicolumn{3}{|c|}{$\begin{array}{l}\text { FY } 1996 \text { Approved Funding } \\
\text { Fuli-Time Equivalents (FTEs) }\end{array}$} & \multicolumn{3}{|c|}{$\begin{array}{l}\text { FY } 1996 \text { Unfunded } \\
\text { Full-Time Equivalents (FTEs) }\end{array}$} & \multicolumn{3}{|c|}{\begin{tabular}{|l|} 
POOL $\mathrm{X}$ \\
FY 1996 Baseline \\
Full-Time Equivalents (FTEs)
\end{tabular}} \\
\hline TYPE OF FTE & Exempt & Non-Exempt & Bargaining & Exempt & Non-Exempt & Bargaining & Exempt & Non-Exempt & Bargaining \\
\hline Organizational & 17.5 & & 61.0 & & & & 17.5 & 0.0 & 61.0 \\
\hline Support & & 0.0 & & & & & 0.0 & 0.0 & 0.0 \\
\hline TOTAL FTES & 17.5 & 0.0 & \begin{tabular}{|c|}
61.0 \\
\end{tabular} & 0. & 0.0 & 0.0 & 17.5 & 0.0 & 61.0 \\
\hline
\end{tabular}

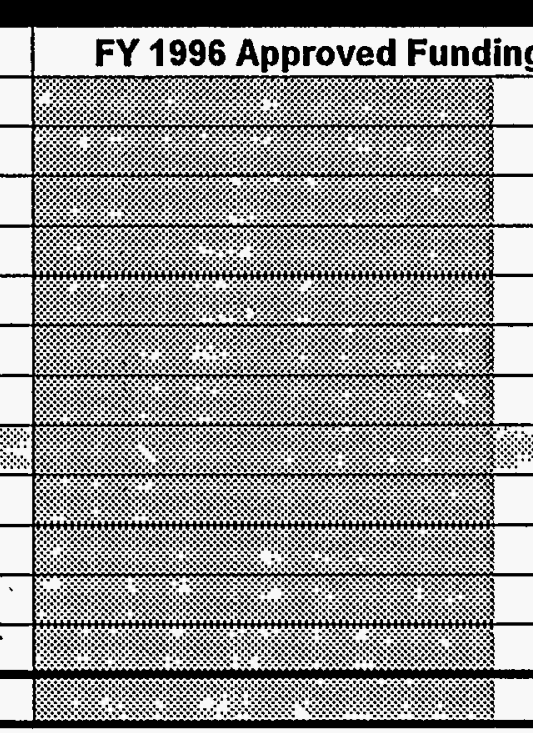

\begin{tabular}{l|l|}
\hline & \\
\hline & 0.0 \\
\hline
\end{tabular}

\section{FY 1996 Unfunded Budget}

COST ELEMENTS

. Labor - Overtime

o Total Labor

1 Materials

2 Purchased Services

3 Other Hanford

8 Revenue

Subtotal originated Costs

4 Site Services

5 Internal Charges

6 IRM Support

7 Overheads

TOTAL DOLLARS

0.0 \%

SIGNATURES

Financial Analyst:

CAM: Date:

\section{FY 1996 Baseline Budget}

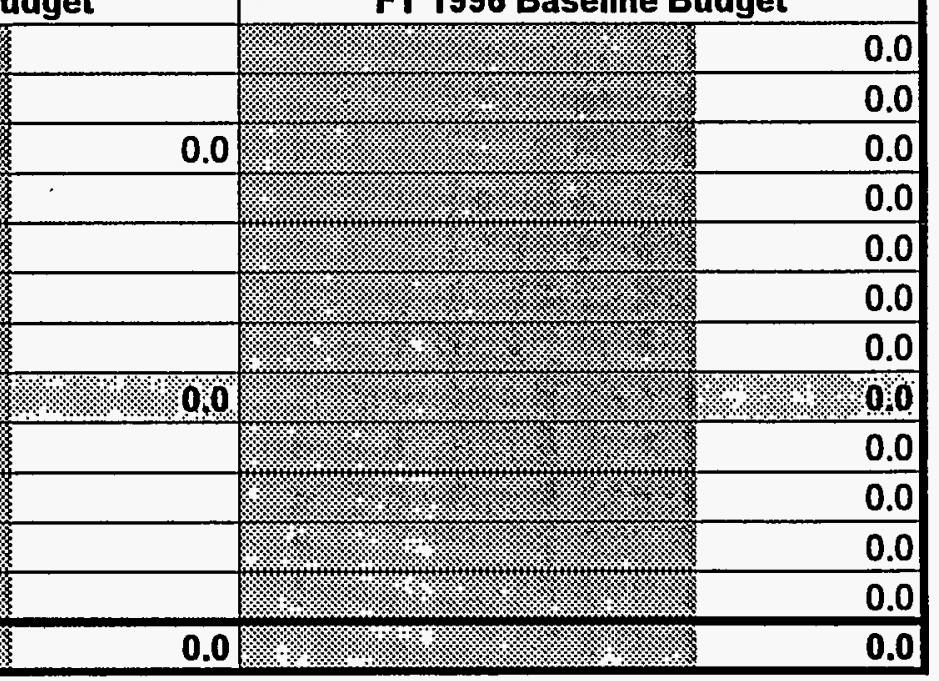

BASELINE APPROVAL

Date: ?

CAM: 


\subsubsection{Program Services [WBS 6.8.4.3]}

6.4.4.1 Mission/Vision. The Program Services mission is to provide Maintenance support to Programmatic customers in areas where the Programs group does not have their own maintenance staff or where, for matters of economics and/or jurisdictional considerations, the proper bargaining unit craft are not available to support programmatic needs. Maintenance support to these programmatic areas and functions includes but is not limited to craft labor, supplied tools, shop machinery support, and supervisory and planning aid.

Maintenance services will encompass corrective, preventive, predictive, modification, fabrication, and trouble shooting activities.

\subsubsection{Goals and Objectives.}

- Place special emphasis on safety while complying with applicable DOE Orders and state and federal requirements.

- Identify needs and be responsive to customer needs to preclude disruptive or goal affecting delays to Site mission clean-up activities and support.

- Obtain manpower resources based upon historical needs and customer projections.

- Conduct work in strict compliance with established procedures and work management controls.

- Provide documented evidence of work performed for customer quality assurance on those systems requiring documentation.

- Assess work on both risk and complexity basis such that performance meets highest quality consummate with lowest risk.

- Be responsive to customer emergencies and provide response to customer needs on a graded approach using manpower in the most cost- and mission-effective manner.

- Support transition initiatives.

\subsubsection{Activities Performed.}

- Work management functions, including but not limited to plan of the day, weekly planning meetings, scheduling functions, job walkdowns, customer liaison, material identification, record keeping, equipment history and recall, ad hoc reports, plant forces work reviews, and regulatory systems/equipment tracking. 
- Corrective maintenance on customer equipment, systems, and/or facilities. Typically 40 percent of customer requests.

- Preventive maintenance on customer equipment, systems, and facilities. Typically 50 percent of customer requests. These activities involve inspections and lubrication of equipment and systems so that unexpected failures are minimized and maintenance activities involving repair and/or replacement can be scheduled on a not-to-interfere basis.

- Predictive maintenance, on customer equipment and systems. Typically 5 percent of requested activities. Predictive maintenance activities involve oil analysis, infrared imaging, ultrasound analysis of check valves and steam traps.

- Fabrication of minor parts and subassemblies. Typically about 5 percent of customer requested activities. Includes fabrication of containers, sheet metal items, sign fabrication, etc.

- Special project support for customer project activities. Typically 1 to 2 percent of requested activities. Involves specialized support to customer projects.

- Refrigeration maintenance support for customers.

- Custodial support for programmatic customers.

\subsubsection{Assumptions and Constraints.}

\subsection{Assumptions.}

- Customer requested support will continue in the same magnitude and categories as experienced in previous years.

- Customer needs survey requests will be promulgated and the results tallied such that organizational manpower can be maintained at an effective and efficient level.

- The programmatic customer requirements will be consistent with the overall Site mission of cleanup.

- Manpower levels for direct-funded work will be shown in man-year figures.

\subsection{Constraints.}

- Increasing constraints in budgetary allotments may downsize customer and be reflected in priorities of requested services. 
- Increasing awareness of costs and the requirement from the U.S. Department of Energy, Richland Operations Office (RL) for costs down to facility level will require a more detailed record of performance such that the customer can report factual costs to DOE.

- Current manpower ceilings preclude effectively servicing the total demands of programmatic customers. Manpower ceilings should be revised based upon factual considerations such as work order funding and work requested/projected by the customer.

\subsubsection{Regulatory Requirements.}

DOE 4320.2A, Site Development and Facility Utilization Planning

DOE 4300.1C, Real Property Management

DOE 4330.4B, Maintenance Management Program

DOE 5480.1B, Environmental, Safety, and Health Program for Department of Energy Operations

Resource Conservation and Recovery Act, Clean Air Act, Environmental Protection Agency, Occupational Safety and Health Administration, State Regulations 


\begin{tabular}{|c|c|c|c|c|c|c|c|c|c|}
\hline $\begin{array}{l}\text { Work } \\
\text { Breakdown } \\
\text { Structure } \\
\text { Dictionary }\end{array}$ & \multicolumn{6}{|c|}{$\begin{array}{l}\text { Westinghouse Hanford Company } \\
\text { Programmatic Services } \\
\text { Part } 1 \text { - Summary } \\
\text { (Dollars in 000's) }\end{array}$} & \multicolumn{3}{|c|}{$\begin{array}{l}\text { FY } 1996 \\
\text { Indirect } \\
\text { Program Plan } \\
\text { Rev. \# } 0 \\
25-\text { Sep-95 }\end{array}$} \\
\hline Cost Account Number & \multicolumn{6}{|c|}{\begin{tabular}{|l} 
Cost Account Title \\
Programmatic Services Summary
\end{tabular}} & \multicolumn{3}{|c|}{$\begin{array}{l}\text { Proposed Rate: } \\
\text { (Rated Service Pool Only) }\end{array}$} \\
\hline $\begin{array}{l}\text { SMS WBS Number } \\
6.8 .4 .3\end{array}$ & \multicolumn{6}{|c|}{\begin{tabular}{|l} 
SMS Title \\
Programmatic Services
\end{tabular}} & \multicolumn{3}{|c|}{ Funding Source: } \\
\hline RL SMS Program Manager & \multicolumn{6}{|c|}{ W.A. Rutherford } & \multicolumn{3}{|l|}{ sws } \\
\hline Cost Account Manager & & & & & & & \multirow{2}{*}{\multicolumn{3}{|c|}{\begin{tabular}{|l|} 
OST \\
DOH \\
\end{tabular}}} \\
\hline WHC SMS Program Manager & \multicolumn{6}{|l|}{ G.A. Harvey } & & & \\
\hline Financial Manager & \multicolumn{6}{|l|}{ M.A. Davis } & \multicolumn{3}{|l|}{ MGT PRO } \\
\hline Responsible Analyst & \multicolumn{6}{|c|}{ M.L. Van Liew } & \multicolumn{3}{|c|}{$\begin{array}{l}\text { POOL } X \\
\text { FY 1996 Baseline } \\
\text { Full-Time Equivalents (FTEs) }\end{array}$} \\
\hline TYPE OF FTE & Exempt & Non-Exempt & Bargaining & Exempt & Non-Exempt & Bargaining & Exempt & Non-Exempt & Bargaining \\
\hline Organizational & 13.6 & 6.8 & 112.4 & & & & 13.6 & 6.8 & 112.4 \\
\hline Support & & & & & & & 0.0 & 0.0 & 0.0 \\
\hline TOTAL FTES & 13.6 & 6.8 & 112.4 & 0. & 0.0 & 0.0 & 13.6 & 6.8 & 112.4 \\
\hline COST ELEMENTS & \multicolumn{3}{|c|}{ FY 1996 Approved Funding Budget } & \multicolumn{3}{|c|}{ FY 1996 Unfunded Budget } & \multicolumn{3}{|c|}{ FY 1996 Baseline Budget } \\
\hline . Labor-Regular & 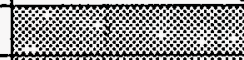 & & & & & & & & 0.0 \\
\hline . Labor - Overtime & & & & & & & & & 0.0 \\
\hline 0 Total Labor & m: & & 0.0 & & & 0.0 & & & 0.0 \\
\hline 1 Materials & (1) & WIIII & & & & & & & 0.0 \\
\hline 2 Purchased Services & 5 & או & & & & & & & 0.0 \\
\hline 3 Other Hanford & (2) & 117. & & 1. & & & T"W & & 0.0 \\
\hline 8 Revenue & 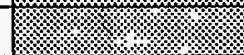 & "ר: & & & & & & & 0.0 \\
\hline Subtotal Orginated Costs & (1. & & 4000 & & & 280.0 & & & 380.0 \\
\hline 4 Site Services & & & & & & & & & 0.0 \\
\hline 5 Internal Charges & 11 & "12. & & & & & & & 0.0 \\
\hline 6 IRM Support & (1) & " & & & & & & & 0.0 \\
\hline 7 Overheads & " & স্যে & & $\because$ & 2 & & 1 & 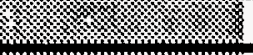 & 0.0 \\
\hline TOTAL DOLLARS & 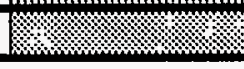 & 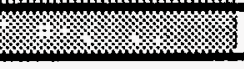 & 0.0 & ? & 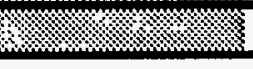 & & $1 \geqslant$ & 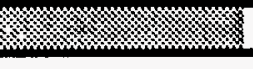 & 0.0 \\
\hline $\begin{array}{l}\text { SIGNATURES } \\
\text { Financial Analyst: } \\
\text { CAM: }\end{array}$ & $\ldots$ & $\overline{ }$ & $\begin{array}{l}\text { Date: } \\
\text { Date: }\end{array}$ & & BASELINEAP & PROVAL & & & \\
\hline
\end{tabular}




\subsubsection{Laundry [WBS 6.8.4.4]}

6.4.5.1 Mission/Vision. Laundry contract management (LCM) serves as the technical monitor to provide overview of RL laundry service contract DE-AC06-93RL12687. This contract provides for cleaning, transportation, and inspection of all respirators, radioactive protective and non-regulated clothing used by RL contractors and subcontractors Site-wide. Inspection of laundry pickup and delivery stations and provide random laundry bag and respirator box sampling to ensure contract requirements are being met. Procurement of replacement clothing and respirators will be direct funded by the user. Procurement will be coordinated through LCM to ensure equal and fair distribution to all users.

\subsubsection{Goals and Objectives.}

- Safety in every task.

- Improve customer service by including all costs in respirator charges.

- Reduce costs with better use of available services.

- Use Safety Observer Program, Behavioral Based Safety Training, Accident Prevention Council services for better safety statistics.

- Complete more surveillances of private contractor deliveries.

- Strive for customer satisfaction.

- Consolidate personal protective equipment and LCM activities.

- Complete laundry/respirator conference.

- Reduce costs.

6.4.5.3 Activities Performed. LCM is responsible for ensuring that the protective clothing and respirators meet all state and federal government standards. LCM is responsible for providing safe, reliable protective equipment and non-regulated clothing to meet all RL contractor requirements for the Hanford Site. This equipment and clothing is used in a wide variety of areas which include radioactive zones, chemical environments, heavy industrial work areas and for casual use between work assignments, breaks, lunchrooms, etc. Laundry and respirator costs are billed to each user through the Hanford Unit Billing System. Specific areas of activity include providing support for:

- Work with WHC, Bechtel Hanford, Inc. (BHI), PNL, and ICF KH safety groups to resolve safety concerns with equipment/clothing.

- Aid with contract negotiations. 
- Review of invoices to ensure payments to private contractor are accurate and provide signature concurrence.

- Provide tours of private contractor facility.

- Coordinate hazardous waste/material shipper activities for shipments.

- Direct WHC traffic for offsite shipments.

- Provide support for WHC radioactivity control technology and BHI, WHC, PNL, and ICF KH operations pickup and delivery of equipment/clothing.

- Deliver replacement parts and clothing to private contractor facility.

- Support shipments of hazardous waste/material shipments.

- Support shipments of replacement equipment/clothing to private contractor from WHC Central Stores.

- Maintain receipts for all shipments from WHC Central Stores to the private contractor.

- Maintain receipts on all hazardous. waste/material shipments.

- Maintain receipts for all equipment/clothing shipments.

- Enter all requisitions for equipment/clothing into Hanford Unit Billing to receive payment for services.

- Serve on Hanford Protective Clothing and Equipment Committee and Hanford Respiratory Protection Committee.

- Attend user safety meetings.

- Hold quarterly user meetings.

\subsubsection{Assumptions. and Constraints.}

\subsection{Assumptions.}

- Current financial system will stay the same as in FY 1995.

- Protective clothing, respirator use and non-regulated clothing usage will not change substantially.

- Additional unfunded work scope will not be added. 
- Consolidating tasks and revamping the WHC Emergency, Safety, and Quality Service, Personal Protective Equipment group will reduce the cost of doing business. When these tasks are consolidated, payment of masks services would be charged through one work order instead of several. This will allow for more cost effective operations.

6.4.5.4.2 Constraints. None.

6.4.5.5 Regulatory Requirements.

Hanford Site Radiological Control Manual (MSRCM-1)

29 CFR 1910.134

ANSI Standards Z88.2 


\begin{tabular}{|c|c|c|c|c|c|c|c|c|c|}
\hline $\begin{array}{l}\text { Work } \\
\text { Breakdọwn } \\
\text { Structure } \\
\text { Dictionạy }\end{array}$ & \multicolumn{6}{|c|}{$\begin{array}{l}\text { Westinghouse Hanford Company } \\
\text { Laundry Summary } \\
\text { Part } 1 \text { - Summary } \\
\text { (Dollars in } 000 \text { 's) }\end{array}$} & \multicolumn{3}{|c|}{$\begin{array}{l}\text { FY } 1996 \\
\text { Indirect } \\
\text { Program Plan } \\
\text { Rev. \# } 0 \\
25-\text { Sep-95 }\end{array}$} \\
\hline Cost Account Number & \multicolumn{6}{|c|}{$\begin{array}{l}\text { Cost Account Title } \\
\text { Laundry Summary }\end{array}$} & \multicolumn{3}{|c|}{$\begin{array}{l}\text { Proposed Rate: } \\
\text { (Rated Service Pool Only) }\end{array}$} \\
\hline $\begin{array}{l}\text { SMS WBS Number } \\
6.8 .4 .4\end{array}$ & \multicolumn{6}{|c|}{$\begin{array}{l}\text { SMS Title } \\
\text { Laundry Summary }\end{array}$} & \multicolumn{3}{|c|}{ Funding Source: } \\
\hline RL SMS Program Manager & \multicolumn{6}{|c|}{ W.A. Rutherford } & \multicolumn{3}{|l|}{ sWS } \\
\hline Cost Account'Manager & \multicolumn{6}{|l|}{ S.E. Albin } & \multicolumn{3}{|l|}{ OST } \\
\hline WHC SMS Program Manager & \multicolumn{6}{|l|}{ G.A. Harvey } & \multicolumn{3}{|l|}{ DOH } \\
\hline Financial Manager & \multicolumn{6}{|l|}{ M.A. Davis } & \multicolumn{3}{|l|}{ MGT PRO } \\
\hline Responsible Analyst & \multicolumn{6}{|c|}{ M.H. Lawrence. } & \multirow{2}{*}{\multicolumn{3}{|c|}{$\begin{array}{l}\text { POOL } X \\
\text { FY 1996 Baseline } \\
\text { Full-Time Equivalents (FTEs) }\end{array}$}} \\
\hline 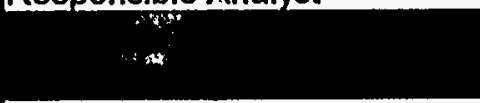 & \multicolumn{3}{|c|}{$\begin{array}{l}\text { FY } 1996 \text { Approved Funding } \\
\text { Full-Time Equivalents (FTEs) }\end{array}$} & \multicolumn{3}{|c|}{$\begin{array}{l}\text { FY } 1996 \text { Unfunded } \\
\text { Full-Time Equivalents (FTEs) }\end{array}$} & & & \\
\hline TYPE OF FTE & Exempt & \begin{tabular}{|l|} 
Non-Exempt \\
\end{tabular} & Bargaining & Exempt & Non-Exempt & Bargaining & Exempt & Non-Exempt & Bargaining \\
\hline Organizational & 1.0 & 1.0 & & & & & 1.0 & 1.0 & 0.0 \\
\hline Support & 4.1 & & & & & & 4.1 & 0.0 & 0.0 \\
\hline TOTAL FTES & 5.1 & 1.0 & 0.0 & 0.0 & 0.0 & 0.0 & 5.1 & 1.0 & 0.0 \\
\hline COST ELEMENTS & FY $1996 \mathrm{~A}$ & pproved Fundi & ing Budget & FY 1996 & 6 Unfunded Bu & dget & FY $19 !$ & 96 Baseline Bt & udget \\
\hline . Labor - Regular & 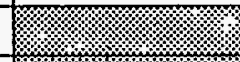 & & 376.0 & & & & & & 376.0 \\
\hline . Labor - Overtime & & & & & & & & & 0.0 \\
\hline 0 Total Labor & & & 376.0 & & & 0.0 & & & 376.0 \\
\hline 1 Materials & & & 20.0 & & & & & & 20.0 \\
\hline 2 Purchased Senvices & & & & & & & & & 0.0 \\
\hline 3 Other Hanford & & & $2,334.0$ & & & & & & $2,334.0$ \\
\hline 8 Revenue & & & & & & & & & 0.0 \\
\hline Subtotal originated costs & (m. & $\sqrt{3}$ & $1.2,730.0$ & & & $1 \% .+0.0$ & 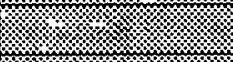 & & 2,7300 \\
\hline 4 Site Services & & & 31.4 & & & & & & 31.4 \\
\hline 5 Internal Charges & (3) & & 3.0 & $\sqrt{3}$ & 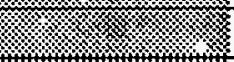 & & & & 3.0 \\
\hline 6 IRM Support & & & 7.0 & & & & & & 7.0 \\
\hline 7 Overheads & I, & 3. & 94.3 & & 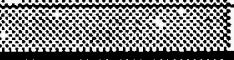 & & , & & 94.3 \\
\hline TOTAL DOLLARS & $7 \cdots$ & & $2,865.7$ & $\sqrt{3}$ & m. & 0.0 & & & $2,865.7$ \\
\hline $\begin{array}{l}\text { SIGNATURES } \\
\text { Financial Analyst: } \\
\text { CAM: }\end{array}$ & & & $\begin{array}{l}\text { Date: }- \\
\text { Date: }\end{array}$ & & BASELINE AP & PROVAL & & & rate: \\
\hline
\end{tabular}




\subsubsection{Environmental [WBS 6.8.4.5]}

6.4.6.1 Mission/Vision. The mission of Environmental Services (North and South) is to provide a complete range of environmental services to ICF KH and some WHC facilities and programs to ensure customer compliance with the applicable environmental regulations.

The vision of Environmental Services is to have fully compliant environmental conditions and be recognized for superior service in the field of environmental waste management.

6.4.6.2 Goals and Objectives. Provide guidance for environmental activities that result in increased safety to personnel and the environment through better implementation of good practices. Effectively manage environmental requirements through education, source reduction, recycling, and efficient waste management.

6.4.6.3 Activities Performed. Additional information on the following activities is contained in the building blocks.
- Waste characterization
- Satellite accumulation area establishment and maintenance
- Radioactive waste management
- Polychlorinated biphenyl (PCB) waste management
- Spill response and cleanup
- Hazardous material control
- Hazardous material inventorying and reporting
- Environmental coordination/support interfaces
- Waste transportation coordination
- Facility specific environmental training
- 90-day accumulation area management
- Sampling and laboratory coordination
- Waste disposal requests
- Field level reporting
- Waste minimization
- Generator training
- Recycling.

\subsubsection{Assumptions and Constraints.}

\subsection{Assumptions.}

- Funding and scope will continue at current levels.

- Identified additional personnel requirements will be filled.

- No significant changes to regulatory requirements are anticipated.

- 200 East 90-day pad will be completed and made operational.

6.4.6.4.2 Constraints. None. 
6.4.6.5 Regulatory Requirements.

42 United States Code (USC) 7401 et seq, Clean Air Act

33 USC 1251 et seq, Clean Water Act

Public Law 101-380, Oil Pollution Act of 1990

7 USC 136 et seq, Federal Insecticide, fungicide, and Rodenticide Act

29 USC 651 et seq, Occupational Safety and Health Act

Public Law 101-508, Pollution Prevention Act of 1990

42 USC 6901 et seq, Resource Conservation and Recovery Act

42 USC 300 fet seq, Safe Drinking Water Act

42 USC 9601 et seq, Comprehensive Environmental Response, Compensation, and Liability Act of 1980 (Superfund)

Superfund Amendment and Reauthorization Act of 1986 (SARA)

Emergency Planning and Community Right-to-Know Act of 1986 (EPCRA)

7 USC 136 et seq, Toxic Substances Control Act

Washington State Administration Code (WAC) 173-303, Washington State Dangerous Waste Regulations 


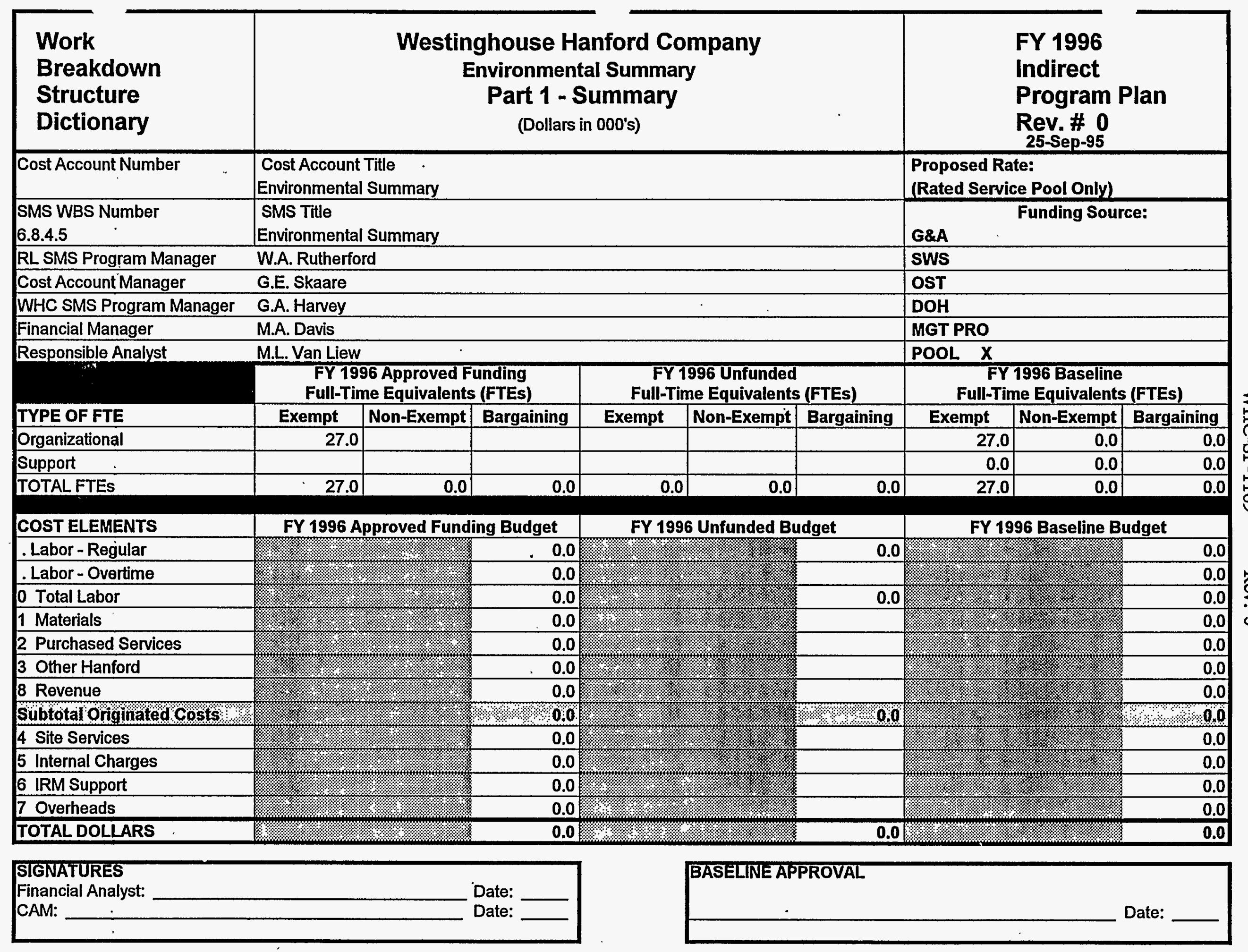




\subsubsection{Transportation Services [WBS 6.8.4.6]}

\subsection{7.i Bus Operations.}

6.4.7.1.1 Mission/Vision. Transit operations provides limited local and regional transportation demand management. Services include paratransit, taxi, guaranteed ride home, shuttle, wrecker, tours, emergency vehicle, and tour support services. Material hauling services include hazardous waste, nonregulated containers, low level mixed waste, purge water, excess equipment and radioactive package/cask deliveries.

\subsection{Goals and Objectives.}

- Provide package and repair parts forwarding service to the outer areas using shuttle services.

- Promote van-pooling and car-pooling.

- Work with the regional transit provider to meet Hanford Site transportation support needs.

\subsection{Activities Performed.}

\section{Transit Operations}

- More than 460 bus tours for RL and all Hanford contractors per year.

- Express shuttle bus service to the 200 Areas.

- Inner and outer area taxi service.

- Guaranteed ride home service providing transportation for overtime and qualified workers from work to home.

- Special transportation requests.

\section{Other Services and Special Tasks}

- Provide paratransit van services.

- Operate the RL managers mini-bus for VIP tours.

- Deliver emergency meals.

- Position Mobile Emergency Command Center.

- Issue and administer gasoline credit cards. 
- Responsible for delivering on-call mobile generator to Kadlec Hospital decontamination facility.

- Provide wrecker service to government-owned vehicles on and off Site.

- Pick up and deliver government-owned vehicles to and from vendors on and off Site.

- Represent Washington State Department of Licensing as a third-party driver testing station.

- Cover off-shift rail operations for control of commercial train movements on government-owned track.

- Washing, cleaning, and fueling of RL managers' vehicles.

- Issue Hanford Site oversize load permits.

- Establish centralized hauling of site-wide hazardous waste.

- Collect purgewater using one purgewater truck for ground water monitoring wells on the Hanford Site.

- Transport hazardous waste and nonregulated waste to the 616 storage disposal and solid waste landfill.

- Transport equipment into and out of the maintenance shops for repairs.

- Transport radioactive shipments throughout the Hanford Site.

- Transport radioactive casks throughout the site.

6.4.7.1.4 Assumptions and Constraints. Funding constraints have placed many activities below budget line, which may optimize on activity but create greater costs in other areas. It is assumed these activities will be funded.

6.4.7.1.5 Regulatory Requirements.

Title 46, Revised Code of Washington (RCW)

Title 49, CFR

Washington State Administrative Code 


\section{Work \\ Breakdown \\ Structure \\ Dictionary}

\section{Westinghouse Hanford Company}

Transportation Services Summary

Part 1 - Summary

(Dollars in 000's)
Cost Account Number

SMS WBS Number

6.8.4.6

RL SMS Program Manager

Cost Account Manager

WHC SMS Program Manager

Financial Manager

Responsible Ánalyst

TYPE OF FTE

Organizational

Support

$\forall$

TOTAL FTES

\section{COST ELEMENTS}

. Labor-Regular

- Labor - Overtime

0 Total Labor

1 Materials

2 Purchased Services

3 Other Hanford

8 Revenue

Subtotal Originated Costs

4 Site Services

5 Internal Charges

6 IRM Support

7 Overheads

TOTAL DOLLARS

\section{Cost Account Title}

Transportation Services Summary

SMS Title

Transportation Services Summary

W.A. Rutherford

R.G. Ciccone

G.A. Harvey

M.A. Davis

R.F. Hilbert

FY 1996 Approved Funding

Full-Time Equivalents (FTEs)

\begin{tabular}{|r|r|r|}
\hline \multicolumn{4}{|c|}{ Full-Time Equivalents (FTEs) } \\
\hline Exempt & Non-Exempt & Bargaining \\
\hline 2.0 & 1.0 & 31.4 \\
\hline & & 0.3 \\
\hline 2.0 & 1.0 & 31.7 \\
\hline
\end{tabular}

FY 1996 Approved Funding Budget

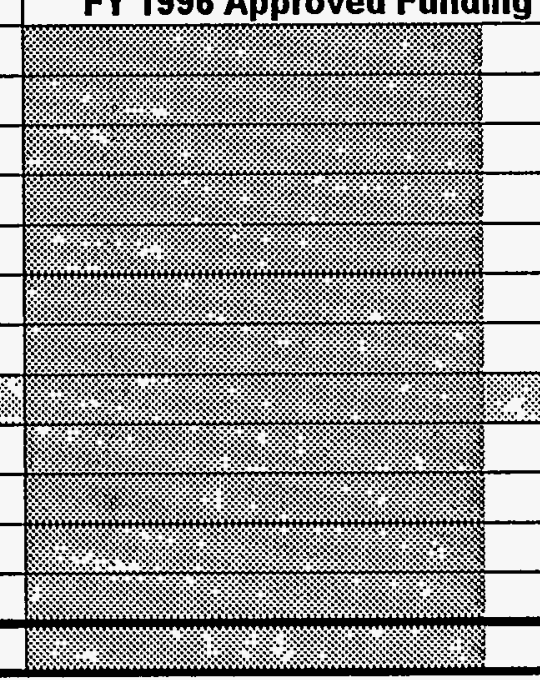

SIGNATURES

Financial Analyst:

Date:

Date:

CAM:
FY 1996 Unfunded

Full-Time Equivalents (FTEs)

Exempt Non-Exempt Bargaining

\begin{tabular}{r|r|r|}
\hline 6.0 & 2.0 & 25.0 \\
\hline 6.0 & & 0.4 \\
\hline
\end{tabular}

FY 1996

Indirect

Program Plan

Rev. \# 0

25-Sep-95

Proposed Rate:

(Rated Service Pool Only)

G\&A

SWS

OST

DOH

MGT PRO

POOL $X$

FY 1996 Baseline

Full-Time Equivalents (FTEs)

\begin{tabular}{l|l|l}
\hline Exempt & Non-Exempt & Bargaining \\
\hline
\end{tabular}

\begin{tabular}{r|r|r|}
\hline t & Non-Exem & Bargaining \\
\hline 8.0 & 3.0 & 56.4 \\
\hline 0.0 & 0.0 & 0.7 \\
\hline 8.0 & 3.0 & 57.1 \\
\hline
\end{tabular}

8.0

0.0

57.1

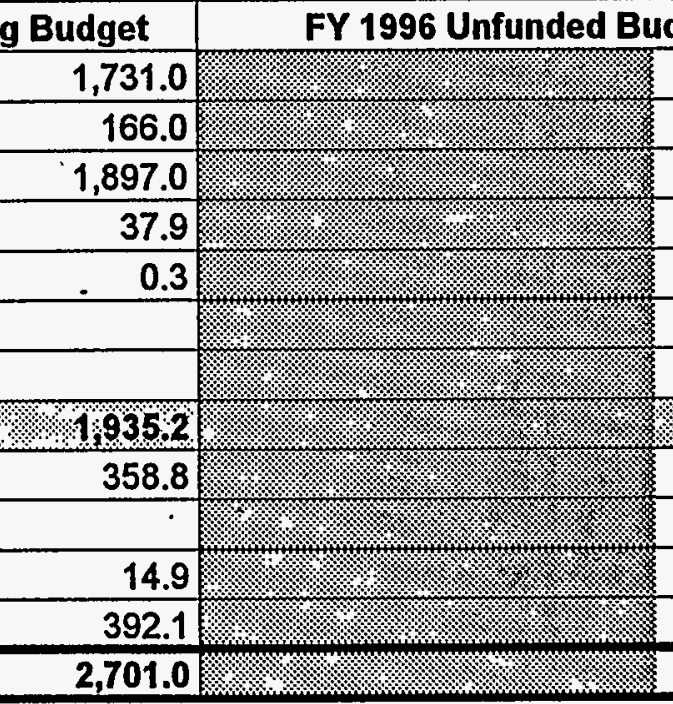

\section{udget}

\begin{tabular}{rr}
425.3 \\
42.3 \\
\hline & 2.0 \\
\hline & 2.5 \\
& 30.6 \\
& 30.0 \\
& 3.2 \\
& 86.8 \\
& 554.1
\end{tabular}

FY 1996 Baseline Budget $2,156.3$

170.3

$2,326.6$

39.9

5

34.10

30.0

3.2

554.1

BASELINE APPROVAL

$\longrightarrow$ Date: $\longrightarrow$ Date: $\longrightarrow$




\subsubsection{Courier and Moving Services}

\subsection{Mission/Vision. (See 8.4.8.1.1)}

6.4.7.2.2 Goals and Objectives. To provide special delivery transportation services, and handling of timely sensitive documents, financial and classified data, motor fuels, furniture, related office equipment and calibrated instruments.

- Continue to build on the special delivery transportation services safety record of 1,000 days without a lost-time injury.

- Reduce the number and frequency of small quantity fuel deliveries.

\subsection{Activities Performed.}

- Deliver packages and mail that are priority or do not fit mail specifications.

- Deliver and move office machinery and computers.

- Move furniture and boxes for Hanford Site contractor employees.

- Office relocations within the Tri-Cities.

- Move record boxes to and from the Records Center.

- Deliver displays and models for the model shop and Speakers Bureau.

- Deliver training supplies and easels for training classes throughout the Tri-Cities.

- Transport and destroy all sensitive and classified scrap.

- Deliver fuel to Hanford Site service stations.

- Fuel vehicles and heavy equipment in field locations.

- Exchange radiation monitoring and calibration instruments for PNL and WHC Standards Laboratory.

6.4.7.2.4 Assumptions and Constraints. Changes in the Hanford Site population will directly impact the special delivery transportation services. Reorganizations and consolidation of facilities significantly increase the number of office and personnel moves. In parallel with these activities, the requirements for transport of excess furniture, office equipment, and fixtures will increase. Document handling and transportation of litigation documents will also remain high as long as federal, state, and legal support groups continue to locate and identify radiation exposed personnel. Many of these items are below the budget line, but we assume they will be funded. 
Staffing will remain at the FY 1995 level.

6.4.7.2.5 Regulatory Requirements.

CFR 49, Parts 171-180 and 390-397

RCW, Title 46 


\subsubsection{Technical Services [WBS 6.8.4.7]}

6.4.8.1 Mission/Vision. The Technical Services organization provides technical maintenance management services for division activities. In addition, technical services are provided to other programmatic divisions/organizations in the areas of maintenance, operations, and electronic technology.

6.4.8.2 Goals and Objectives. Provide technical safety consulting services to internal and programmatic departments pertaining to maintenance management, operations, and technology. Ensure all work is performed safely and in compliance with required procedures to understand the regulatory requirements for procedures, and to ensure that excessive regulations are not imposed. That all reports, training, and other administrative support activities are completed accurately and on time, at minimal costs. Provide tools (both manpower and systems) that ensure maintenance management activities are performed in the most efficient and cost effective manner.

\subsubsection{Activities Performed. Additional information can be found in the building blocks.}

- Provide continual industrial assessments, such that the performance is consistent with the highest standards observed in commercial applications.

- Provide work management training for personnel to assure understanding of requirements that will lead to significant reduction in costs and upgraded

- performance. In addition, provide tracking of training to assure that each employee performance can be evaluated.

- Conduct work management process development and administration for the division and other organizations to ensure efficient conduct of business.

- Provide technical support for maintenance and operations functions, including development of procedures and processes to assure continually meeting goals and Site missions.

- Conduct self-assessments for organizations within the division to assure compliance with standards, directives, and orders. Provide a method for tracking observations and findings of assessments to closure.

- Industrial Safety program consultation.

- Provide methods and data for detailing performance measurements to assure trends can be identified as either positive or corrective actions can be taken to redirect adverse trends.

- Provide continual procedure review and comments for designated company procedures and provide administrative control, review,-issue, and update for all division procedures and desk instructions. 
6.4.8.4 Assumptions and Constraints.

\subsection{Assumptions.}

- Safety will be the continuing top priority for all operations.

- Requirements for operational excellence will have an increasing emphasis.

- Customer requests for procedure and technical support will continue at about the FY 1995 level.

6.4.8.4.2 Constraints. Manpower ceilings will continue to constrain available resources limiting customer response.

6.4.8.5 Regulatory Requirements.

TBD. 


\section{Work \\ Breakdown \\ Structure \\ Dictionary}

Cost Account Number

SMS WBS Number

6.8.4.7

RL SMS Program Manager

Cost Account Manager

WHC SMS Program Manager

Financial Manager

Responsible Analyst

TYPE OF FTE

Organizational

Support

TOTAL FTES

\section{COST ELEMENTS}

. Labor-Regular

- Labor-Overtime

0 Total Labor

1 Materials

2 Purchased Services

3 Other Hanford

8 Revenue

Subtotal Originated costs

4 Site Services

5 Internal Charges

6 IRM Support

7 Overheads

TOTAL DOLLARS

\section{SIGNATURES}

Financial Analyst:

CAM:

\section{Westinghouse Haı Iford Company}

Technical Services Summary

Part 1 - Summary

(Dollars in 000's)

Cost Account Title

Technical Services Summary

SMS Title

Technical Services Summary

W.A. Rutherford

E. Petersen

G.A. Harvey

M.A. Davis

M. L. Van Liew

FY 1996 Approved Funding

Full-Time Equivalents (FTEs) \begin{tabular}{r|r|r|} 
Exempt & Non-Exempt & Bargaining
\end{tabular}

\begin{tabular}{|r|r|r|}
\hline Exempt & Non-Exempt & Bargaining \\
\hline 5.6 & & \\
\hline 5.6 & 0.0 & 0.0 \\
\hline
\end{tabular}

\begin{tabular}{|r|r|}
\hline \multicolumn{2}{|c}{ FY1996 } \\
Full-Time \\
\hline Exempt & N \\
\hline & \\
\hline & 0.0 \\
\hline
\end{tabular}

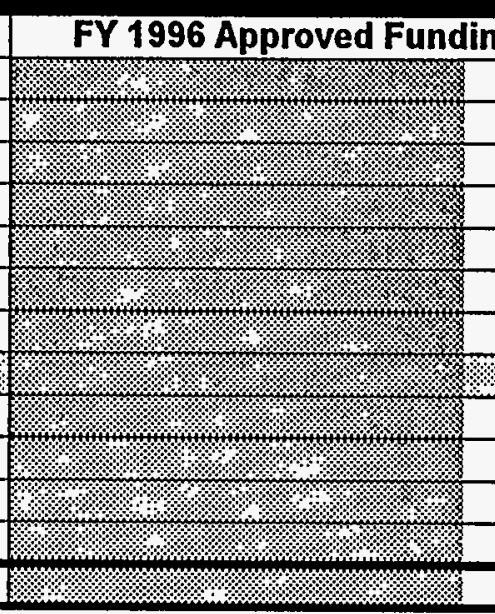

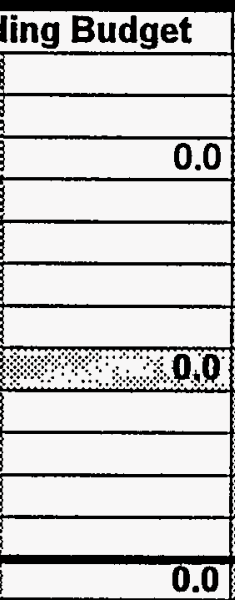

FY 1996 Unfunded Budget

0.0
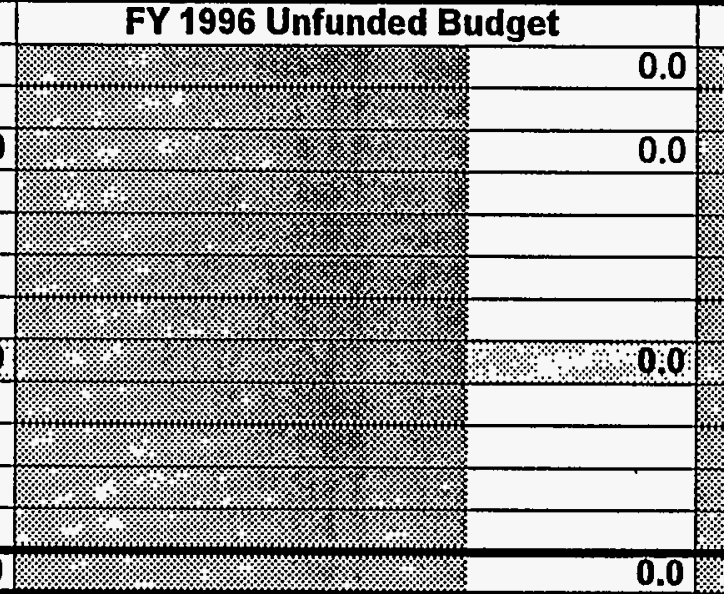

BASELINE APPROVAL
FY 199b

Indirect

Program Plan

Rev. \# 0

25-Sep-95

Proposed Rate:

(Rated Service Pool Only)

G\&A

SWS

OST

DOH

MGT PRO

POOL $X$

Funding Source:

FY 1996 Baseline

Full-Time Equivalents (FTEs)

\begin{tabular}{l|l|l|} 
Exempt & Non-Exempt & Bargaining \\
\hline
\end{tabular}

\begin{tabular}{|c|c|c|}
\hline 5.6 & 0.0 & 0.0 \\
\hline 0.0 & 0.0 & 0.0 \\
\hline 5.6 & 0.0 & 0.0 \\
\hline
\end{tabular}

0.0

\section{FY 1996 Baseline Budget}

-

00.0 .00

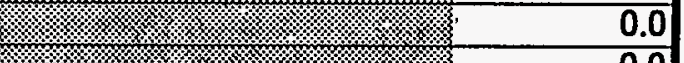

$\begin{array}{lll}. & 0.0 \\ .\end{array}$

r $\quad 0.0$

1.

.

0.0

Date:

Date:

Date: 



\subsection{Appendix E Energy Management}





\section{CONTENTS}

\subsection{APPENDIX E - RESOURCE AND ENERGY MANAGEMENT [WBS}

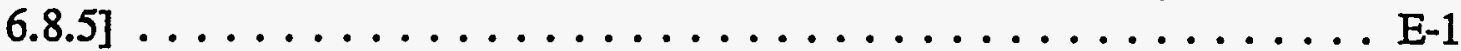

6.5 .1 Mission/Vision $\ldots \ldots \ldots \ldots \ldots \ldots \ldots \ldots \ldots \ldots \ldots \ldots$

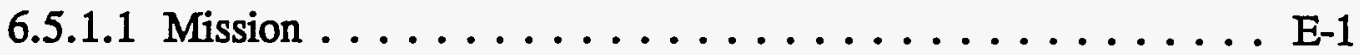

6.5 .1 .2 Vision $\ldots \ldots \ldots \ldots \ldots \ldots \ldots \ldots \ldots \ldots \ldots \ldots$

6.5.1.3 Performance Measures. . . . . . . . . . . . . . E-1

6.5.2 In-house Energy Management [WBS 6.8.5.1] . . . . . . . E-2

6.5.2.1 Mission/Vision ................. E-2

6.5.2.2 Goals and Objectives $\ldots \ldots \ldots \ldots \ldots \ldots$ E-2

6.5.2.3 Activities Performed ................ E-3

6.5.2.4 Assumptions and Constraints . . . . . . . . . E E-3

6.5.2.5 Regulatory Requirements . . . . . . . . . . . E-4

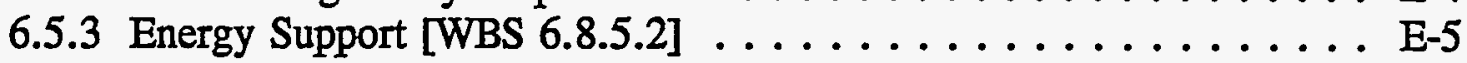

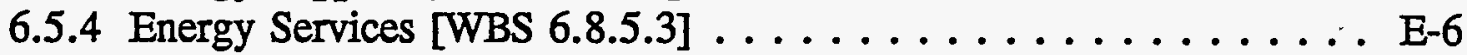

6.5.4.1 Mission/Vision ................ E-6

6.5.4.2 Goals and Objectives $\ldots \ldots \ldots \ldots \ldots \ldots \ldots$ E-6

6.5.4.3 Activities Performed . . . . . . . . . . . . . . E-9

6.5.4.4 Assumptions and Constraints ... . . . . . . . E-10

6.5.4.5 Regulatory Requirements . . . . . . . . . . . . . E-10

6.5.4.6 Above Target Funding. . . . . . . . . . . . . E-10 


\section{LIST OF TABLES}

E-1 FY 1996 Cost Baseline by Program Element . . . . . . . . . . . . . . . E-12

E-2 Milestone Description Sheet . . . . . . . . . . . . . . . E-13

E-3 WBS Dictionary $\ldots \ldots \ldots \ldots \ldots \ldots \ldots \ldots \ldots \ldots \ldots \ldots \ldots \ldots \ldots \ldots \ldots$ 


\subsection{APPENDIX E - RESOURCE-AND ENERGY MANAGEMENT [WBS 6.8.5]}

\subsubsection{Mission/Vision}

6.5.1.1 Mission. Resource and Energy Management has the responsibility to reduce mortgage costs by sponsoring life-cycle, cost effective, energy efficient projects. The team's use of an existing process to validate energy savings upon project completion justifies progress towards reducing mortgage costs and allows more taxpayer dollars to be focused into the actual cleanup of the site.

As this mission statement supports the:

(1) Energy Policy Act requirement for the Department of Energy to seek out and implement all energy efficiency projects at its facilities with a payback period of 10 years or less by FY 2005; and

(2) Executive Order 12902 requirement that energy and water management goals be incorporated into facility management contracts,

DOE has recommended that top level support for the Resource and Energy Management program be continued.

6.5.1.2 Vision. The Resource and Energy Management vision is to promote a Hanford Site that is efficient, competitive in relation to standard industry baselines, environmentally sound, and the Department of Energy (DOE) model for energy and resource management and the use of federal funds.

\subsubsection{Performance Measures.}

Quantitatively measure an overall site energy cost reduction exceeding 1\% of the FY94 costs of $\$ 13.5$ million, based on validated Resource and Energy Management championed projects, incidental reductions incurred by facility shutdown are to be excluded unless specifically enhanced by Resource and Energy Management team activities.

Provide a 300 percent return on investment (accepted industry performance measure) based on a comparison of funding received from Landlord Program element 7.5.1 with the total value of validated energy savings from Resource and Energy. Management championed projects, plus any innovative financing and contracting. Mechanism funding acquired, including but not limited to utility demand side management programs, energy savings performance contracting, and shared energy savings. 


\subsubsection{In-house Energy Management [WBS 6.8.5.1]}

6.5.2.1 Mission/Vision. Conduct approved In-house Energy Management (IHEM) funded studies and life cycle, cost effective, energy efficient projects which reduce mortgage costs and increase Site competitiveness.

6.5.2.2 Goals and Objectives. This financial support is separate and distinct from contract funds, and can only be used for approved work scope. Contract funding must be used to identify, develop, or submit study and project proposals, Site assessed costs, general employee training, and other normal costs of doing business on the Hanford Site.

- Conduct all activities according to safety and environmental compliance regulations.

- Complete IHEM funded energy studies to identify projects which reduce mortgage costs consistent with the goals of Executive Orders 12902 and 12759, within budgeted scope and DOE guidelines supporting these activities.

- Complete five IHEM funded studies by May 30, 1996 (existing).

- Complete IHEM funded energy projects which reduce mortgage costs consistent with the goals of Executive Orders 12902 and 12759, within budgeted scope and DOE guidelines supporting these activities.

- Complete IHEM funded project E-022, 300 Area Clearwell Water Pump Drive Improvements, by September 30, 1996 (existing).

- Complete IHEM funded project E-027, Reconfigure 230kV Transmission System, by September 30, 1996 (existing).

- Conduct an energy and water prioritization survey to:

(a) establish priorities for conducting comprehensive facility audits.

(b) develop a 7-year plan to conduct or obtain comprehensive audits of Site facilities by 2002 .

(c) determine potential reduction in the use of petroleum in buildings and facilities by switching to a less-polluting and non petroleum-based energy source, such as natural gas or solar and other renewable energy sources where they are cost-effective.

(d) develop a building list for exemption from energy and water conservation reduction requirements to FEMP and Office of Management and Budget (OMB). 
(e) Where feasible, use a total building approach to energy conservation, providing energy savings and a more safe and productive environment for building occupants.

- Complete IHEM Study EMS-88a, Energy Service Contract Company Phase I, and submit study findings by May 30, 1996 (existing).

- Submit list to be considered for exemption from energy and water conservation reduction requirements to FEMP and OMB by July 31, 1996 (existing).

- Develop a 7-year plan by July 31, 1996, to ensure comprehensive audits of Site facilities are completed by 2002 (existing).

\subsubsection{Activities Performed.}

6.5.2.3.1 Activities conducted for IHEM energy studies and projects include coordinating and/or directly performing building, facility, and systems studies, such as comprehensive audits, walk-throughs, future mission, and plans; analyzing data, generating a findings report, cost saving measures evaluation, justification analysis, project description, functional design, implementation strategy, funding alternatives, and design review and coordination.

This financial support is separate and distinct from contract funds, and can only be used for approved work scope. In-house Energy Management funding cannot be used to identify, develop, or submit study and project proposals, Site assessed costs, general employee training, or other normal costs of doing business on the Hanford Site.

- Historically, IHEM studies and projects have been the active ingredient to reduce energy consumption, which in turn lowers mortgage costs. This financial support is separate and distinct from contract funds, and is provided contingent upon allowing sufficient contract operating funds to administer the program. The IHEM program is but one non-contract funding source which if eliminated would detract from, but not eliminate, the Site's ability to achieve compliance with energy conservation regulations:

\subsubsection{Assumptions and Constraints.}

\subsection{Assumptions.}

- In-house Energy Management funding will be available to fund studies and projects.

- In-house Energy Management studies will be completed within 12 months of funding. 
- In-house Energy Management projects will be completed as scheduled in change requests.

\subsection{Constraints.}

- In-house Energy Management funding may not be available to fund all studies and projects.

- Any delay in receipt of IHEM funding from date of approval prevents proper assignment of personnel and completion by assigned due date.

\subsubsection{Regulatory Requirements.}

- DOE general requirements.

- DOE 4330.2D, In-house Energy Management Program.

- DOE 4540.1C, Utility Acquisition and Management.

- DOE 6430.1A, General Design Criteria.

- 1990 amendments to Public Law 101-549, Clean Air Act.

- Public Law 102-486, Energy Policy Act of 1992.

- Executive Order 12759, Federal Energy Management.

- Executive Order 12902, Energy Efficiency and Water Conservation at Federal Facilities.

- Title 10 Code of Federal Regulations (CFR) 435, Energy Conservation Performance Standards for New Buildings (mandatory federal).

- Title 10 CFR 436, Federal Energy Management and Planning Programs.

Staff are well versed in ASHRAE 90.1 and the 1994 Washington State Non-Residential Energy Code, Washington Administrative Code WAC 51-11 in the event of cancellation of DOE orders and adoption of commercial industrial standards. 


\subsubsection{Energy Support [WBS 6.8.5.2]}

Indirect funding has been identified as unfunded in FY 1996. 


\subsubsection{Energy Services [WBS 6.8.5.3]}

6.5.4.1 Mission/Vision. Reduce mortgage costs using direct-funded programs to identify, develop, and submit study and project proposals funded by contract and non-contract resources to seek out and implement all life cycle, cost effective, energy efficient projects with a payback period of 10 years or less by FY 2005. To justify improvement toward operating costs, projects are validated for the first three years of post retrofit operation to verify energy savings and show progress towards reducing mortgage costs.

\subsubsection{Goals and Objectives.}

- Conduct all activities according to safety and environmental compliance regulations.

- Collect and input energy consumption statistics into Site database for all energy types in the categories of buildings, metered process, and vehicles and equipment to provide a comparison to baseline FY 1985 consumption as required by IHEM and EO 12902.

- Submit quarterly energy conservation performance reports through the Energy Management System 2 (EMS2) not later than 40 calendar days after the end of each quarter of the fiscal year (existing).

- Document a building energy consumption of at least 14 percent less than the FY 1985 baseline, based on energy consumption per gross square meter (foot) of buildings in use, not later than 40 calendar days after the end of the fiscal year (proposed; existing, 11 percent). An interim goal to ensure 20 percent reduction by the year 2000 (Executive Order 12759) and 30 percent by the year 2005 (extension to existing goal, pursuant to Executive Order 12902).

- Document a metered process energy consumption of at least 20 percent as compared to the FY 1990 baseline, based on energy consumption per gross square meter (foot) of buildings in use, not later than 40 calendar days after the end of the fiscal year (existing). A maintenance goal to ensure 20 percent reduction by the year 2005 (extension to existing goal, pursuant to Executive Order 12902). Although goal exceeded in FY 1991 with 24.8 percent reduction, environmental cleanup activities will incur additional energy use.

- Analyze energy consumption data at the Hanford Site to identify, develop, and submit IHEM study and project proposals to reduce mortgage costs and increase Site competitiveness. 
- Identify and submit IHEM funding requests for new studies totaling a minimum of $\$ 500,000$ by July 31, 1996 (proposed, reduced due to decreased staff; existing, $\$ 800,00)$.

- Identify and submit IHEM funding requests for new projects totaling a minimum of $\$ 2$ million by August 31, 1996 (existing).

- Fiscal management of IHEM funded studies and projects, and investigate and report schedule and cost variances.

- Submit quarterly IHEM energy study and project status reports provide progress, cost and schedule data, and any problem areas with proposed resolutions not later than 40 calendar days after the end of each quarter of the fiscal year.

- Coordinate expansion of Site metering program for direct bill back to consumers (IHEM, O\&M audits)

- Complete prototype installation and development of report format by September 30, 1996 (proposed).

- Develop and submit life-cycle, cost-effective, energy efficient project proposals from comprehensive audits of facilities performed within the past three years, for installation of energy efficiency, water conservation, and renewable energy technologies.

- Submit life-cycle, cost-effective, energy efficient project proposals from comprehensive audits of facilities performed within the past three years for funding consideration by August 31, 1996 from other resources to be identified (proposed).

- Use innovative financing and contracting mechanisms including but not limited to utility demand side management programs, energy savings performance contracting, and shared energy savings (EO 12902).

- Achieve $\$ 200,000$ worth of innovative financing by September 30, 1996 (proposed; existing $\$ 100,000$ ).

- Implement the 7-year plan to promote installation of all energy and water conservation measures with less than 10 year simple payback and SIR greater than one by the year 2005 .

- Begin implementation of 7-year comprehensive plan by September 15, 1996 (proposed). 
- Review design and construction of new facilities or retrofit projects to minimize the life cycle cost by using energy efficiency, water conservation, solar or other renewable energy technologies.

- Ensure that the design and construction of facilities that are to be either owned or leased to the Federal Government meet or exceed the energy performance standards applicable to Federal residential or commercial buildings as set forth in 10 CFR 435 or local building standards, whichever will result in a lower life cycle cost over the life of the facility.

- Validate Resource and Energy Management championed projects for the first three years of post retrofit operation to document an energy consumption of at least 1 percent less than FY 1994 (reduced mortgage costs) based on completed energy projects by September 30, 1996. Exclude incidental reductions incurred by facility shutdowns unless specifically enhanced by Resource and Energy Management team activities.

- Establish and implement a building commissioning program by August 15, 1996 (proposed).

- Work with procurement officials to identify and eliminate internal regulations, procedures, or other barriers to purchase energy-efficient products, institute mechanisms to set targets and measure progress.

- Identify and report progress towards elimination of internal regulations, procedures, or other procurement barriers by September 30, 1996 (proposed).

- Develop accounting procedures for realizing 50 percent of savings from energy efficiency and water conservation efforts to reinvest into additional resource efficiency measures.

- Have an accounting procedure in place by September 30, 1996 to realize 50 percent of savings from energy efficiency and water conservation efforts beginning October 1, 1996 (proposed).

- Develop a building automation strategy with Utilities, taking into account new systems installed.

- Develop a building automation strategy with Utilities by September 30, 1996 (proposed).

- Promote energy and resource conservation sharing activities to inform employees how their actions impact energy consumption at the Hanford Site. 
- Submit 12 articles for publication, maintain and update the energy conservation opportunity database, maintain cc:mail employee suggestion program for site resource engineering improvements, and provide computer disk slide show awareness program for employees by September 30, 1996 (existing).

- Maintain an annual rate of return of at least 300 percent on investment, considered the industry standard by state energy offices and commercial businesses.

- Document an annual rate of return of at least 300 percent on investment not later than 40 calendar days after the end of the fiscal year (existing).

- Prepare an annual report describing progress in achieving the goals of Executive Order 12902.

- Submit an annual report describing progress in achieving the goals of Executive Order 12902 by November 30, 1995 (existing).

- Customer satisfaction as measured from feedback surveys.

- Conduct at least one customer survey per year with RL and customers by. September 30, 1996 (existing).

\subsubsection{Activities Performed.}

6.5.4.3.1 Activities conducted as a cost of doing business on the Hanford Site include: reviewing design and construction of new facilities or retrofit projects to minimize life cycle costs and validating savings; coordinating and/or directly performing building, facility, and systems studies, such as comprehensive audits, walk-throughs, future mission, and plans; analyzing data, generating a findings report, cost saving measures evaluation, justification analysis, project description, functional design, implementation strategy, funding alternatives, and design review and coordination; completing required safety and Site training, preparing weekly and monthly reports, preparing budgets and monthly budget variance explanations, promoting energy and resource conservation sharing activities, implementing a comprehensive 7-year building facility audit plan, working with procurement officials to identify and eliminate barriers to purchase energy-efficient products, and other assignments as requested by management.

Activities conducted as a cost of doing business with IHEM include: preparing IHEM funded study and project quarterly status reports; compiling annual summary report; maintaining energy consumption database and compiling and inputting energy consumption statistics; analyzing Site energy consumption data; developing and submitting IHEM study proposals; formulating, developing, and conducting engineering evaluations of alternatives; cost estimating and life-cycle cost evaluations; project scheduling and planning development; 
preparing and approving study documentation; developing and submitting IHEM project proposals; responding to IHEM comments as required.

- Loss of more than $\$ 10$ million in direct funded studies and projects which assist DOE in seeking. out and implementing all energy efficiency projects at its facilities in compliance with federal energy reduction goals and regulations.

- Loss of an estimated $\$ 200,000$ in Bonneville Power Administration rebates.

- Loss of more than $\$ 135,000$ in energy savings due to abandoned energy projects.

- Loss of program and ability to assist DOE in accomplishing its task of implementing required energy efficiency projects.

- Lack of top level support for program as requested by DOE in award fee criteria.

- Site buildings will not be built or retrofit to federal requirements resulting in deteriorating benchmark operating costs.

\subsubsection{Assumptions and Constraints.}

\subsection{Assumptions.}

- Present Bonneville Power Administration reimbursement for products and services will result in $\$ 200,000$ worth of rebates received.

- The program guidance will provide necessary funding for agreed-upon scope.

\subsection{Constraints.}

- Utility reimbursements will evolve to a new program requiring rebate contract modifications.

- The program guidance will not provide necessary funding for agreed-upon scope.

\subsubsection{Regulatory Requirements.}

- Please refer to section 6.5.2.5.

\subsubsection{Above Target Funding.}

- Conduct surveys and audits of leased facilities to the extent practicable and to the extent that the recommendations of such surveys and audits could be implemented under the terms of the lease. 
- Coordinate successful implementation of efficiency, water conservation, and solar and other renewable energy projects in their position descriptions and performance evaluations of personnel.

- Review company incentive programs to ensure that such programs appropriately reward exceptional performance in implementing the Energy Policy Act of 1992 and Executive Order 12902.

- Maintain a strong energy awareness program, including conducting an elementary poster contest, printing a full-color appointment scheduler, coordinating technical energy seminars, designing, printing, and distributing bulletin board information flyers, and adopting an employee beneficial suggestions program for energy and water management improvement.

- Defer heater and fan requisition responsibility to RL (Federal Property Management Regulations, 41 CFR ch. 101, section 20.107 (d), and DOE Order 4330.2D, In-house Energy Management.) 
Table E-1. FY 1996 Cost Baseline by Program Element.

\begin{tabular}{|c|c|c|c|c|c|c|}
\hline WBS \# & Title & $\begin{array}{l}\text { FY95 } \\
\text { Total \$ }\end{array}$ & $\begin{array}{l}\text { FY96 } \\
\text { Total \$ }\end{array}$ & $\begin{array}{l}\text { FY97 } \\
\text { Total \$ }\end{array}$ & $\begin{array}{l}\text { FY98 } \\
\text { Total \$ }\end{array}$ & $\begin{array}{l}\text { FY99 } \\
\text { Total \$ }\end{array}$ \\
\hline 6.8.5.1.1 & IHEM Studies/Projects & $2801.5^{1}$ & $\begin{array}{l}1798.3^{2} \\
5550.0^{3}\end{array}$ & $\begin{array}{l}\text { Carryov } \\
\text { er }{ }^{\text {TBD }} \\
2175.0^{4}\end{array}$ & TBD & TBD \\
\hline 6.8 .5 .1 .2 & Energy Support & 477.0 & 0.0 & TBD & TBD & TBD \\
\hline 6.8 .5 .1 .3 & Energy Services & 60.0 & $2550.0^{5}$ & TBD & TBD & TBD \\
\hline & $\begin{array}{l}\text { Note: numbers include } \\
\text { adders }\end{array}$ & & & & & \\
\hline & & & & & & \\
\hline & & & & & & \\
\hline & & & & & & \\
\hline & & & & & & \\
\hline & & & & & & \\
\hline
\end{tabular}

Excludes company adders (G\&A and CSP/Oversight)

${ }^{1}$ Includes IHEM projects - BA/BO, \$1849.4K; IHEM studies - new BA/BO, \$375.0K; low cost studies (RFS), \$90.0K; and 1995 study carryover, \$487.1K.

${ }^{2}$ FY 1996 carryover estimates include \$573.2K for studies and \$1225.1K for projects.

${ }^{3}$ Proposed for FY 1996 includes \$350K for IHEM studies and the following IHEM projects: \$3700K for PFP HVAC energy upgrade; $\$ 1500 \mathrm{~K}$ for electric meter direct bill back/ESPC validation. Does not include $\$ 1200 \mathrm{~K}$ requested for 337 HVAC/CFC upgrade.

${ }^{4}$ Includes \$2000K for proposed water meter direct bill back/ESPC validation project and \$175K for Energy Service Contract Company phase.

Includes two pollution prevention proposals: . Remote (Solar) Lighting, \$150K; Replace Incandescent Lamps, \$2000K; and $\$ 400 \mathrm{~K}$ from Landlord Programs. 
Table E-2. Milestone Description Sheet.

Title: Complete In-house Energy Management Study EMS-45b, HVAC Economizer Investigation Phase II

Assigned To: In-house Energy Management

Date Prepared:

$09 / 26 / 95$

\begin{tabular}{|c|c|c|c|}
\hline \multicolumn{3}{|c|}{ Assigned To: In-house Energy Management } & CIN: \\
\hline \multicolumn{3}{|c|}{ WBS Designator: 6.8 .5 .1} & $\begin{array}{l}\text { Due Date: } \\
5 / 30 / 96\end{array}$ \\
\hline \multicolumn{3}{|c|}{ Control Number: SSP-96-E02 } & Revision: \\
\hline $\begin{array}{l}\text { Milestone Type: } \\
\square \text { DOE-HQ } \\
\square \text { DOE-RL } \\
\square \text { CNTR }\end{array}$ & $\begin{array}{l}\text { Division: } \\
\square \text { State } \\
\square \text { Federal } \\
\square \text { DOE } \\
\square \text { RCRA } \\
\square \text { TPA\# }\end{array}$ & $\begin{array}{l}\text { Deliverable: } \\
\square \text { Report } \\
\square \text { Letter } \\
\square \text { Drawings } \\
\square \text { Other } \\
\text { (specify) }\end{array}$ & $\begin{array}{l}\text { Address To: } \\
\square \text { DOE-HQ } \\
\square \text { DOE-RL } \\
\square \text { Other } \\
\text { (specify) }\end{array}$ \\
\hline
\end{tabular}

Milestone Description

Close out IHEM Study EMS-45b, HVAC Economizer Investigation Phase II, including documentation and all viable options which meet IHEM project funding requirements of a savings investment ration (SIR) greater than 1.0 , and a simple payback less than 10 years. with a minimum of 50 percent of the savings comprised from energy.

Description of what constitutes completion of this milestone:

Submit cover letter and study report to W. A. Rutherford, DOE-RL.

\begin{tabular}{|c|c|}
\hline $\begin{array}{l}\text { Cost Account Manager } \\
\text { W. S. Dunnivant }\end{array}$ & $\begin{array}{l}\text { Program/Project Manzer } \\
\text { G. A. Harvey }\end{array}$ \\
\hline $\begin{array}{l}\text { Program Element Manager } \\
\text { W. S. Dunnivant L t.oDtems }\end{array}$ & $\begin{array}{l}\text { DOE Monitor } \\
\text { W. A. Rutherford }\end{array}$ \\
\hline
\end{tabular}


Table E-2. Milestone Description Sheet.

\begin{tabular}{|c|c|c|c|}
\hline \multicolumn{3}{|c|}{$\begin{array}{l}\text { Title: Complete In-house Energy Management Study EMS-88a, } \\
\text { Energy Service Contract Company Phase I }\end{array}$} & $\begin{array}{l}\text { Date Prepared: } \\
09 / 26 / 95\end{array}$ \\
\hline \multicolumn{3}{|c|}{ Assigned To: In-house Energy Management } & CIN: \\
\hline \multicolumn{3}{|c|}{ WBS Designator: 6.8 .5 .1} & $\begin{array}{l}\text { Due Date: } \\
5 / 30 / 96\end{array}$ \\
\hline \multicolumn{3}{|c|}{ Control Number: SSP-96-E03 } & Revision: \\
\hline $\begin{array}{l}\text { Milestone Type: } \\
\square \text { DOE-HQ } \\
\square \text { DOE-RL } \\
\square \text { CNTR }\end{array}$ & $\begin{array}{l}\text { Division: } \\
\square \text { State } \\
\square \text { Federal } \\
\square \text { DOE } \\
\square \text { RCRA } \\
\square \\
\text { TPA\# }\end{array}$ & $\begin{array}{l}\text { Deliverable: } \\
\square \text { Report } \\
\square \text { Letter } \\
\square \text { Drawings } \\
\square \text { Other } \\
\text { (specify) }\end{array}$ & $\begin{array}{l}\text { Address To: } \\
\square \text { DOE-HQ } \\
\square \text { DOE-RL } \\
\square \text { Other } \\
\text { (specify) }\end{array}$ \\
\hline
\end{tabular}

\section{Milestone Description}

Close out IHEM Study EMS-88a, Energy Service Contract Company Phase I, including: documentation and all viable options which meet IHEM project funding requirements of a savings investment ratio (SIR) greater than 1.0, and a simple payback less than 10 years with a minimum of 50 percent of the savings comprised from energy; identify high priority government facilities for comprehensive facility audits (priority will be determined by the degree of cost effective projects identified in the surveys); determine potential reduction in the use of petroleum in buildings and facilities by switching to a less-polluting and non petroleum-based energy source, such as natural gas or solar and other renewable energy sources where they are cost-effective; where feasible, use a total building approach to energy conservation, providing energy savings and a more safe and productive environment for building occupants.

Description of what constitutes completion of this milestone:

Submit cover letter and study report to W. A. Rutherford, DOE-RL.

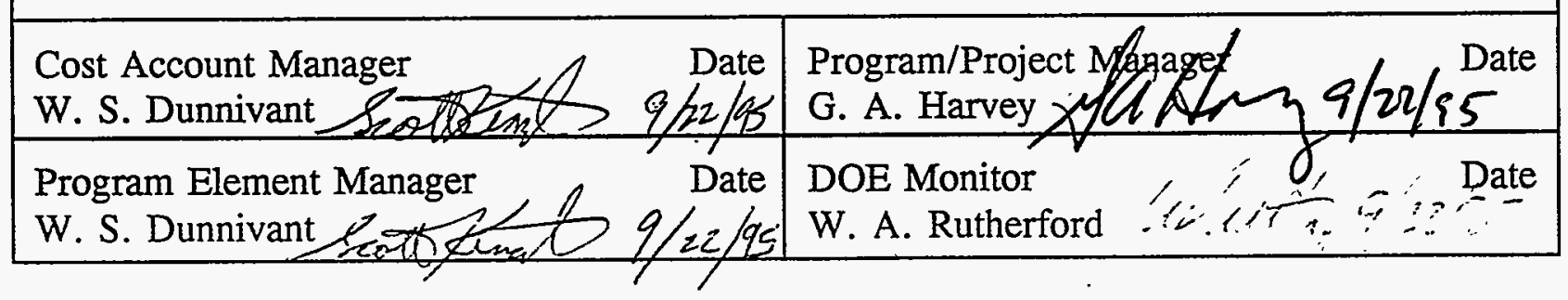


Table E-2. Milestone Description Sheet.

\begin{tabular}{|c|c|c|c|}
\hline \multicolumn{3}{|c|}{$\begin{array}{l}\text { Title: Complete In-house Energy Management Study EMS-89, } \\
\text { Water Pumping Efficiency }\end{array}$} & $\begin{array}{l}\text { Date Prepared: } \\
09 / 26 / 95\end{array}$ \\
\hline \multicolumn{3}{|c|}{ Assigned To: In-house Energy Management } & CIN: \\
\hline \multicolumn{3}{|c|}{ WBS Designator: 6.8 .5 .1} & $\begin{array}{l}\text { Due Date: } \\
5 / 30 / 96\end{array}$ \\
\hline \multicolumn{3}{|c|}{ Control Number: SSP-96-E04 } & Revision: \\
\hline $\begin{array}{l}\text { Milestone Type: } \\
\square \text { DOE-HQ } \\
\square \text { DOE-RL } \\
\square \text { CNTR }\end{array}$ & $\begin{array}{l}\text { Division: } \\
\square \text { State } \\
\square \text { Federal } \\
\square \text { DOE } \\
\square \text { RCRA } \\
\square \\
\square \\
\text { TPA\# }\end{array}$ & $\begin{array}{l}\text { Deliverable: } \\
\square \text { Report } \\
\square \text { Letter } \\
\square \text { Drawings } \\
\square \text { Other } \\
\text { (specify) }\end{array}$ & $\begin{array}{l}\text { Address To: } \\
\square \text { DOE-HQ } \\
\square \text { DOE-RL } \\
\square \text { Other } \\
\text { (specify) }\end{array}$ \\
\hline \multicolumn{4}{|c|}{ Milestone Description } \\
\hline \multicolumn{4}{|c|}{$\begin{array}{l}\text { Close out IHEM Study EMS- } 89 \text {, Water Pumping Efficiency, including documentation and } \\
\text { all viable options which meet IHEM project funding requirements of a savings investment } \\
\text { ration (SIR) greater than } 1.0 \text {, and a simple payback less than } 10 \text { years with a minimum of } \\
50 \text { percent of the savings comprised from energy. }\end{array}$} \\
\hline \multicolumn{4}{|c|}{ Description of what constitutes completion of this milestone: } \\
\hline \multicolumn{4}{|c|}{ Submit cover letter and study report to W. A. Rutherford, DOE-RL. } \\
\hline \multicolumn{2}{|c|}{ 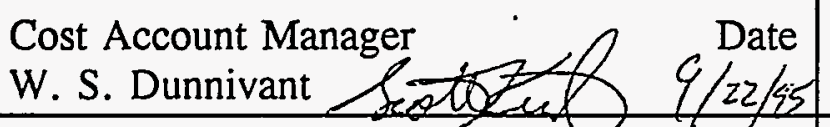 } & \multicolumn{2}{|c|}{$\begin{array}{l}\text { Program/Project Manager } \\
\text { G. A. Harvey } P / A / 24 / 45\end{array}$} \\
\hline \multicolumn{2}{|c|}{ 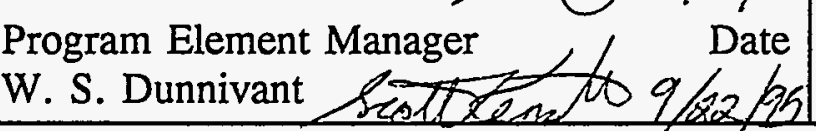 } & \multicolumn{2}{|c|}{$\begin{array}{l}\text { DOE Monitor } \\
\text { W. A. Rutherford }\end{array}$} \\
\hline
\end{tabular}


Table E-2. Milestone Description Sheet.

Title: Complete In-house Energy Management Study EMS-90a, Sitewide Deactivated Facilities Study Phase I

\begin{tabular}{|c|c|c|c|}
\hline \multicolumn{3}{|c|}{ Assigned To: In-house Energy Management } & CIN: \\
\hline \multicolumn{3}{|c|}{ WBS Designator: 6.8 .5 .1} & $\begin{array}{l}\text { Due Date: } \\
5 / 30 / 96\end{array}$ \\
\hline \multicolumn{3}{|c|}{ Control Number: SSP-96-E05 } & Revision: \\
\hline $\begin{array}{l}\text { Milestone Type: } \\
\square \text { DOE-HQ } \\
\square \text { DOE-RL } \\
\square . \text { CNTR }\end{array}$ & $\begin{array}{l}\text { Division: } \\
\square \text { State } \\
\square \text { Federal } \\
\square \text { DOE } \\
\square \text { RCRA } \\
\square \\
\square \\
\text { TPA\# }\end{array}$ & $\begin{array}{l}\text { Deliverable: } \\
\square \text { Report } \\
\square \text { Letter } \\
\square \text { Drawings } \\
\square \text { Other } \\
\text { (specify) }\end{array}$ & $\begin{array}{l}\text { Address To: } \\
\square \text { DOE-HQ } \\
\square \text { DOE-RL } \\
\square \text { Other } \\
\text { (specify) }\end{array}$ \\
\hline
\end{tabular}

Close out IHEM Study EMS-90a, Sitewide Deactivated Facilities Study Phase I, including documentation and all viable options which meet IHEM project funding requirements of a savings investment ration (SIR) greater than 1.0, and a simple payback less than 10 years with a minimum of 50 percent of the savings comprised from energy.

Description of what constitutes completion of this milestone:

Submit cover letter and study report to W. A. Rutherford, DOE-RL.

\begin{tabular}{|c|c|}
\hline anager & G. \\
\hline Dunnivant Manager & W \\
\hline
\end{tabular}


Table E-2. Milestone Description Sheet.

Title: Complete In-house Energy Management Study EMS-91a, Fume Hoods

\begin{tabular}{|c|c|c|c|}
\hline \multicolumn{3}{|l|}{ Fume Hoods } & $09 / 26 / 95$ \\
\hline \multicolumn{3}{|c|}{ Assigned To: In-house Energy Management } & CIN: \\
\hline \multicolumn{3}{|c|}{ WBS Designator: 6.8 .5 .1} & $\begin{array}{l}\text { Due Date: } \\
5 / 30 / 96\end{array}$ \\
\hline \multicolumn{3}{|c|}{ Control Number: SSP-96-E06 } & Revision: \\
\hline $\begin{array}{l}\text { Milestone Type: } \\
\square \text { DOE-HQ } \\
\text { DOE-RL } \\
\square \text { CNTR }\end{array}$ & $\begin{array}{l}\text { Division: } \\
\square \text { State } \\
\square \text { Federal } \\
\square \text { DOE } \\
\square \text { RCRA } \\
\square \\
\text { TPA\# }\end{array}$ & $\begin{array}{l}\text { Deliverable: } \\
\square \text { Report } \\
\square \text { Letter } \\
\square \text { Drawings } \\
\square \text { Other } \\
\text { (specify) }\end{array}$ & $\begin{array}{l}\text { Address To: } \\
\square \text { DOE-HQ } \\
\mathbf{~ D O E - R L ~} \\
\square \text { Other } \\
\text { (specify) }\end{array}$ \\
\hline \multicolumn{4}{|c|}{ Milestone Description } \\
\hline \multicolumn{4}{|c|}{$\begin{array}{l}\text { Close out IHEM Study EMS-91a, Fume Hoods, including documentation and all viable } \\
\text { options which meet IHEM project funding requirements of a savings investment ration } \\
\text { (SIR) greater than } 1.0 \text {, and a simple payback less than } 10 \text { years with a minimum of } 50 \\
\text { percent of the savings comprised from energy. }\end{array}$} \\
\hline \multicolumn{4}{|c|}{ Description of what constitutes completion of this milestone: } \\
\hline \multicolumn{4}{|c|}{ Submit cover letter and study report to W. A: Rutherford, DOE-RL. } \\
\hline \multicolumn{2}{|c|}{$\begin{array}{l}\text { Cost Account Manager } \\
\text { W. S. Dunnivant Sate }\end{array}$} & \multicolumn{2}{|c|}{$\begin{array}{l}\text { Program/Project Mangger } \\
\text { G. A. Harvey } 9 / 22 / 98\end{array}$} \\
\hline \multicolumn{2}{|c|}{$\begin{array}{l}\text { Program Element Manager } \\
\text { W. S. Dunnivant }\end{array}$} & \multicolumn{2}{|c|}{$\begin{array}{l}\text { DOE Monitor } \\
\text { W. A. Rutherford }\end{array}$} \\
\hline
\end{tabular}


Table E-2. Milestone Description Sheet.

Title: Complete In-house Energy Management Project E-022, 300 Area Clearwell Water Pump Drive Improvements

Assigned To: In-house Energy Management

Date Prepared:

09/26/95

\begin{tabular}{|c|c|c|c|}
\hline \multicolumn{3}{|c|}{ Assigned 10: In-house Energy Management } & CIN: \\
\hline \multicolumn{3}{|c|}{ WBS Designator: 6.8 .5 .1} & $\begin{array}{l}\text { Due Date: } \\
9 / 30 / 96\end{array}$ \\
\hline \multicolumn{3}{|c|}{ Control Number: SSP-96-E07 } & Revision: \\
\hline $\begin{array}{l}\text { Milestone Type: } \\
\square \text { DOE-HQ } \\
\square \text { DOE-RL } \\
\square \text { CNTR }\end{array}$ & $\begin{array}{l}\text { Division: } \\
\square \text { State } \\
\square \text { Federal } \\
\square \text { DOE } \\
\square \text { RCRA } \\
\square \\
\text { TPA\# }\end{array}$ & $\begin{array}{l}\text { Deliverable: } \\
\square \text { Report } \\
\square \text { Letter } \\
\square \text { Drawings } \\
\square \text { Other } \\
\text { (specify) }\end{array}$ & $\begin{array}{l}\text { Address To: } \\
\square \text { DOE-HQ } \\
\square \text { DOE-RL } \\
\square \text { Other } \\
\text { (specify) }\end{array}$ \\
\hline
\end{tabular}

Milestone Description

Close out IHEM Project E-022, 300 Area Clearwell Water Pump Drive Improvements, including Schedule-44 and four C's.

Description of what constitutes completion of this milestone:

Submit cover letter and project report to W. A. Rutherford, DOE-RL.

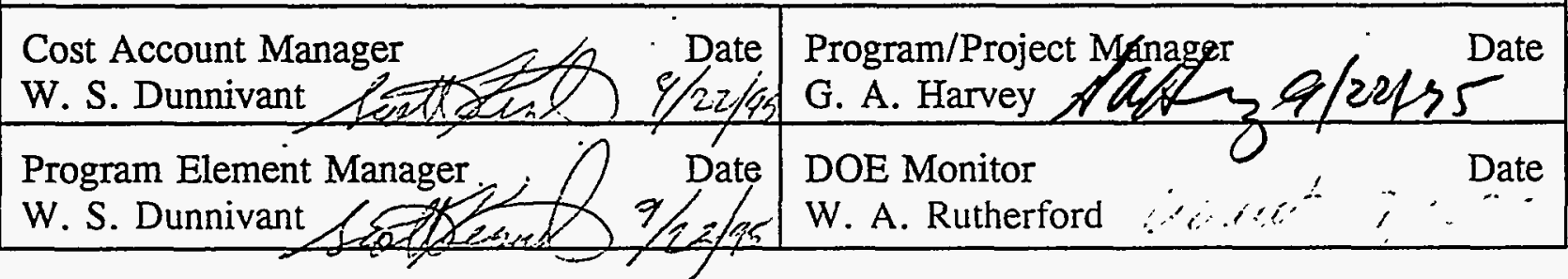


Table E-2. Milestone Description Sheet.

\begin{tabular}{|c|c|c|c|}
\hline \multicolumn{3}{|c|}{$\begin{array}{l}\text { Title: Complete İn-house Energy Management Project E-027, } \\
\text { Reconfigure } 230 \mathrm{kV} \text { Transmission System }\end{array}$} & $\begin{array}{l}\text { Date Prepared: } \\
09 / 26 / 95\end{array}$ \\
\hline \multicolumn{3}{|c|}{ Assigned To: In-house Energy Management } & CIN: \\
\hline \multicolumn{3}{|c|}{ WBS Designator: 6.8 .5 .1} & $\begin{array}{l}\text { Due Date: } \\
9 / 30 / 96\end{array}$ \\
\hline \multicolumn{3}{|c|}{ Control Number: SSP-96-E08 } & Revision: \\
\hline $\begin{array}{l}\text { Milestone Type: } \\
\square \text { DOE-HQ } \\
\square \text { DOE-RL } \\
\square \text { CNTR }\end{array}$ & $\begin{array}{l}\text { Division: } \\
\square \text { State } \\
\square \text { Federal } \\
\mathbf{1} \text { DOE } \\
\square \text { RCRA } \\
\square \\
\text { TPA\# }\end{array}$ & $\begin{array}{l}\text { Deliverable: } \\
\square \text { Report } \\
\square \text { Letter } \\
\square \text { Drawings } \\
\square \text { Other } \\
\text { (specify) }\end{array}$ & $\begin{array}{l}\text { Address To: } \\
\square \text { DOE-HQ } \\
\square \text { DOE-RL } \\
\square \text { Other } \\
\text { (specify) }\end{array}$ \\
\hline \multicolumn{4}{|c|}{ Milestone Description } \\
\hline \multicolumn{4}{|c|}{$\begin{array}{l}\text { Close out IHEM Project E-027, Reconfigure } 230 \mathrm{kV} \text { Transmission System, including } \\
\text { Schedule } 44 \text { and four C's. }\end{array}$} \\
\hline \multicolumn{4}{|c|}{ Description of what constitutes completion of this milestone: } \\
\hline \multicolumn{4}{|c|}{ Submit cover letter and project report to W. A. Rutherford, DOE-RL. } \\
\hline \multicolumn{2}{|c|}{$\begin{array}{l}\text { Cost Account Manager } \\
\text { W. S. Dunnivant }\end{array}$} & \multicolumn{2}{|c|}{$\begin{array}{l}\text { Program/Project Managgt } \\
\text { G. A. Harvey X/C/24/95 }\end{array}$} \\
\hline \multicolumn{2}{|c|}{$\begin{array}{l}\text { Program Element Manager } \\
\text { W. S. Dunnivant }\end{array}$} & \multicolumn{2}{|c|}{$\begin{array}{l}\text { DOE Monitor } \\
\text { W. A. Rutherford }\end{array}$} \\
\hline
\end{tabular}


Table E-2. Milestone Description Sheet.

\begin{tabular}{|c|c|c|c|}
\hline \multicolumn{3}{|c|}{$\begin{array}{l}\text { Title: Submit annual report describing progress in achieving } \\
\text { EO } 12902 \text { goals. }\end{array}$} & $\begin{array}{l}\text { Date Prepared: } \\
09 / 26 / 95\end{array}$ \\
\hline \multicolumn{3}{|c|}{ Assigned To: In-house Energy Management } & CIN: \\
\hline \multicolumn{3}{|c|}{ WBS Designator: 6.8 .5 .3} & $\begin{array}{l}\text { Due Date: } \\
11 / 30 / 95\end{array}$ \\
\hline \multicolumn{3}{|c|}{ Control Number: SSP-96-E01 } & Revision: \\
\hline $\begin{array}{l}\text { Milestone Type: } \\
\square \text { DOE-HQ } \\
\square \text { DOE-RL } \\
\square \text { CNTR }\end{array}$ & $\begin{array}{l}\text { Division: } \\
\square \text { State } \\
\square \text { Federal } \\
\square \text { DOE } \\
\square \text { RCRA } \\
\square \\
\text { TPA\# }\end{array}$ & $\begin{array}{l}\text { Deliverable: } \\
\square \text { Report } \\
\square \text { Letter } \\
\square \text { Drawings } \\
\square \text { Other } \\
\text { (specify) }\end{array}$ & $\begin{array}{l}\text { Address To: } \\
\square \text { DOE-HQ } \\
\square \text { DOE-RL } \\
\square \text { Other } \\
\text { (specify) }\end{array}$ \\
\hline \multicolumn{4}{|c|}{ Milestone Description } \\
\hline \multicolumn{4}{|c|}{ Submit annual report describing progress in achieving EO 12902 goals. } \\
\hline \multicolumn{4}{|c|}{ Description of what constitutes completion of this milestone: } \\
\hline \multicolumn{4}{|c|}{$\begin{array}{l}\text { Letter submitted to W. A. Rutherford, DOE-RL, documenting progress towards achieving } \\
\text { the goals of Executive Order } 12902 \text {. }\end{array}$} \\
\hline \multicolumn{2}{|c|}{$\begin{array}{l}\text { Cost Account Manager } \\
\text { W. S. Dunnivant }\end{array}$} & \multicolumn{2}{|c|}{$\begin{array}{l}\text { Program/Project } \\
\text { G. A. Harvey Xager } 9 / 22 / 95\end{array}$} \\
\hline \multicolumn{2}{|c|}{$\begin{array}{l}\text { Program Element Manager } \\
\text { W. S. Dunnivant }\end{array}$} & \multicolumn{2}{|c|}{$\begin{array}{l}\text { DOE Monitor } \\
\text { W. A. Rutherford } \cdots, \text { Date }\end{array}$} \\
\hline
\end{tabular}




\begin{tabular}{|c|c|c|c|c|c|c|c|c|c|}
\hline $\begin{array}{l}\text { Work } \\
\text { Breakdown } \\
\text { Structure } \\
\text { Dictionary }\end{array}$ & \multicolumn{6}{|c|}{$\begin{array}{c}\text { Westinghouse Hanford Company } \\
\text { Energy Management } \\
\text { Part } 1 \text { - Summary } \\
\text { (Dollars in 000's) }\end{array}$} & \multicolumn{3}{|c|}{$\begin{array}{l}\text { FY } 1996 \\
\text { Indirect } \\
\text { Program Plan } \\
\text { Rev. \# } 0 \\
25-\text { Sep-95 }\end{array}$} \\
\hline Cost Account Number & \multicolumn{6}{|c|}{\begin{tabular}{|l|} 
Cost Account Title \\
Energy Management
\end{tabular}} & \multicolumn{3}{|c|}{$\begin{array}{l}\text { Proposed Rate: } \\
\text { (Rated Service Pool Only) }\end{array}$} \\
\hline $\begin{array}{l}\text { SMS WBS Number } \\
\text { 6.8.5.1 }\end{array}$ & \multicolumn{6}{|c|}{$\begin{array}{l}\text { SMS Title } \\
\text { Energy Management }\end{array}$} & \multicolumn{3}{|c|}{ Funding Source: } \\
\hline RL SMS Program Manager & \multicolumn{6}{|c|}{ W.A. Rutherford } & \multicolumn{3}{|l|}{ SWS } \\
\hline Cost Account Manager & \multicolumn{6}{|c|}{ W.S. Dunnivant } & \multicolumn{3}{|l|}{ OST } \\
\hline WHC SMS Program Manager & \multicolumn{6}{|l|}{ G.A. Harvey } & \multicolumn{3}{|l|}{ DOH } \\
\hline Financial Manager & \multicolumn{6}{|l|}{ M.A. Davis } & \multicolumn{3}{|l|}{ MGT PRO } \\
\hline Responsible Analyst & \multicolumn{6}{|c|}{ M.H. Lawrence } & \multirow{2}{*}{\multicolumn{3}{|c|}{$\begin{array}{|cc|}\text { POOL } & X \\
& \text { FY T996 Baseline } \\
\text { Full-Time Equivalents (FTEs) } \\
\end{array}$}} \\
\hline & \multicolumn{3}{|c|}{$\begin{array}{c}\text { FY T996 Approved Funding } \\
\text { Full-Time Equivalents (FTEs) }\end{array}$} & \multicolumn{3}{|c|}{$\begin{array}{l}\text { FY } 1996 \text { Unfunded } \\
\text { Full-Time Equivalents (FTEs) }\end{array}$} & & & \\
\hline TYPE OF FTE & Exempt & \begin{tabular}{|l|} 
Non-Exempt \\
\end{tabular} & Bargaining & Exempt & Non-Exempt & Bargaining & Exempt & \begin{tabular}{|l|} 
Non-Exempt \\
\end{tabular} & Bargaining \\
\hline Organizational & & & & 0.0 & & & 0.0 & 0.0 & 0.0 \\
\hline Support & & & & & & & 0.0 & 0.0 & 0.0 \\
\hline TOTAL FTES & 0.0 & 0.0 & 0.0 & 0.0 & 0.0 & 0.0 & 0.0 & 0.0 & 0.0 \\
\hline COST ELEMENTS & \multicolumn{3}{|c|}{ FY 1996 Approved Funding Budget } & FY 199 & 6 Unfunded Bt & Idget & \multicolumn{3}{|c|}{ FY 1996 Baseline Budget } \\
\hline . Labor - Regular & & & & & & & & & $\$ 0.0$ \\
\hline . Labor - Overtime & & & & & & & & & 0 \\
\hline 0 Total Labor & & & $\$ 0.0$ & & & $\$ 0.0$ & & 率 & $\$ 0.0$ \\
\hline 1 Materials & & &. & & & & & 筮 & 0.0 \\
\hline 2 Purchased Services & & & & & & & & & 0.0 \\
\hline 3 Other Hanford & & & & & & & 策新 & 柆 & 0.0 \\
\hline 8 Revenue & & & 0.0 & & & & & (1) & 0.0 \\
\hline Subtotal originated Costs & & & ४४ $\$ 500$ & & & $\% \$ 50: 0$ & & 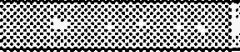 & $\$ 0.0$ \\
\hline 4 Site Services & & 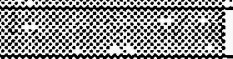 & & & 原: & & /. & 格 & 0.0 \\
\hline 5 Internal Charges & (1) & (1. & & ?: & x.m. & & ?. & & 0.0 \\
\hline 6 IRM Support & 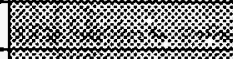 & 劄学 & & & & & 策原 & m. & 0.0 \\
\hline 7 Overheads & 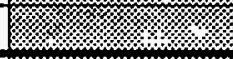 & & & 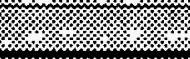 & থ. & & $\lim _{2}$ & 柊 & 0.0 \\
\hline TOTAL DOLLARS & \% & & $\$ 0.0$ & (1) & mas & $\$ 0.0$ & m: & \%: & $\$ 0.0$ \\
\hline $\begin{array}{l}\text { SIGNATURES } \\
\text { Financial Analyst: } \\
\text { CAM: }\end{array}$ & & & $\begin{array}{l}\text { Date: } \\
\text { Date: }\end{array}$ & & BASELINE AF & PROVAL & & & Date: \\
\hline
\end{tabular}

${ }^{\star}$ Energy Management will be funded in WBS 7.5 in FY 1996. 



\subsection{Appendix F Programmatic}





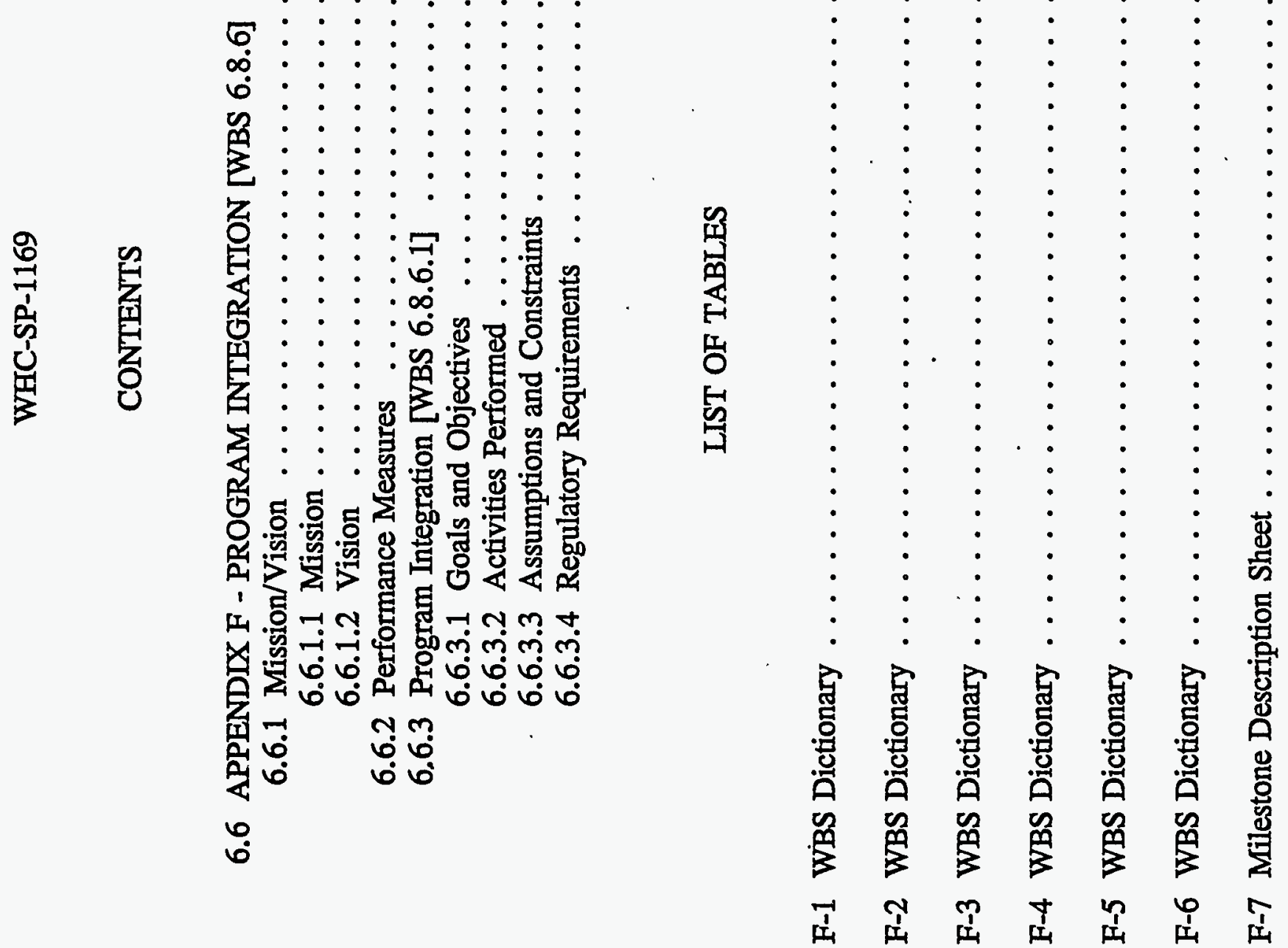




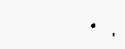




\subsection{APPENDIX F - PROGRAM INTEGRATION [WBS 6.8.6]}

\subsubsection{Mission/Vision}

6.6.1.1 Mission. The mission of Program Integration is to preserve, upgrade, maintain, operate, and forecast cost effective program integration programs to facilitate the Hanford Site cleanup mission. All Program Integration activities will be performed in an environmentally sound, safe, economical, prudent, and reliable manner.

Hanford Site Program Integration programs will be competitive with commercially provided services to offer the best price, quality, and service available.

6.6.1.2 Vision. The program vision is a direct result of the Hanford Strategic Plan (DOE/RL-93-102) and the strategic goals within the plan. In particular, goal \#3 states "we will provide a safe infrastructure (e.g., utilities, transportation, general purpose facilities, or Sitewide services) in a cost effective way that supports accomplishment of the Hanford mission and meets or exceeds appropriate standards." The vision and strategic goals provide the basis for this program plan.

\section{Strategies:}

- Identify and understand program integration requirements including core capabilities to be retained.

- Determine the best alternative (competitive with the best commercial services) for continuing to provide the required program integration.

- Implement the best alternative considering capability, capacity, safety, and reliability.

- Bring together management, employees, organized labor, and the community to find continuing employment for affected workers as the Site transitions.

Success Indicators:

- Improvement toward benchmark operating costs.

- The number of OSHA reportables where program integration is a.contributing cause.

- The number of missed or changed Hanford milestones where program integration is the cause. 


\subsubsection{Performance Measures}

Over/under liquidation of department overhead's, budgeted cost of work performed/actual cost of work performed.

\subsubsection{Program Integration [WBS 6.8.6.1]}

\subsubsection{Goals and Objectives.}

- Facilitate management of scope, cost, and schedule baselines including changes to the baseline

- Provide monthly program integration status reports through approved Site systems.

- Provide central location to acquire resources to support infrastructure needs

- Landlord Program office will be the central infrastructure location beginning October 1, 1995.

- Provide central point of contact for communications on infrastructure matters

- Establish life cycle strategies to facilitate a longer-term horizon for planning

- Issue life cycle strategies to support long-term planning consistent with schedule developed by Site Planning.

- Coordinate preparation of the SSPP and MYPP

- Complete SSPP and MYPP documents by September 30, 1996.

\subsubsection{Activities Performed.}

- Provide a program baseline that includes a technical scope of work, a schedule with critical paths identified, and a cost profile.

- Provide a system to identify and evaluate risks, and to integrate these risks into planning, prioritization, and decision processes.

- Provide program development, integration and administration

- Provide program integration and support to line management

- Provide management of program element activities 
- Provide program leadershị for planning, program integration, energy management and transition activities

- Provide strategic planning

- Provide systems engineering integration into infrastructure planning.

6.6.3.3 Assumptions and Constraints.

\subsection{Assumptions.}

- Programmatic and scheduling support will continue to be provided.

- Integration of Landlord Program (7.5) with this program will continue to be programmatic workscope.

- System engineering will continue to be applied as it matures.

\subsection{Constraints.}

- Funding and staffing reductions may reduce programmatic support

- Funding may not be available for all upgrades, major repairs, or line items and may require changes in programmatic support

\subsubsection{Regulatory Requirements.}

DOE 5100.3 Field Budget Process 


\begin{tabular}{|c|c|c|c|c|c|c|c|c|c|}
\hline $\begin{array}{l}\text { Work } \\
\text { Breakdown } \\
\text { Structure } \\
\text { Dictionary }\end{array}$ & \multicolumn{6}{|c|}{$\begin{array}{l}\text { Westinghouse Hanford Company } \\
\text { Infrastructure Programs } \\
\text { Part } 1 \text { - Summary } \\
\text { (Dollars in.000's) }\end{array}$} & \multicolumn{3}{|c|}{$\begin{array}{l}\text { FY } 1996 \\
\text { Indirect } \\
\text { Program Plan } \\
\text { Rev.\# } 0 \\
25-\text { Sep-95 }\end{array}$} \\
\hline Cost Account Number & \multicolumn{6}{|c|}{\begin{tabular}{|l|} 
Cost Account Title \\
Infrastructure Programs
\end{tabular}} & \multicolumn{3}{|c|}{\begin{tabular}{|l|} 
Proposed Rate: \\
(Rated Service Pool Only)
\end{tabular}} \\
\hline $\begin{array}{l}\text { SMS WBS Number } \\
6.8 .6 .1\end{array}$ & \multicolumn{6}{|c|}{\begin{tabular}{|l|} 
SMS Title \\
Infrastructure Programs \\
\end{tabular}} & \multicolumn{3}{|c|}{\begin{tabular}{|c|} 
Funding Source: \\
\end{tabular}} \\
\hline RL SMS Program Manager & \multicolumn{6}{|c|}{ W.A. Rutherford } & \multicolumn{3}{|l|}{ sws } \\
\hline Cost Account Manager & \multicolumn{6}{|l|}{ G.A. Harvey } & \multicolumn{3}{|l|}{ OST } \\
\hline WHC SMS Program Manager & \multicolumn{6}{|l|}{ G.A. Harvey } & \\
\hline Financial Manager & \multicolumn{6}{|l|}{ M.A. Davis } & \multirow{2}{*}{\multicolumn{3}{|c|}{\begin{tabular}{|lc|} 
MGT PRO & $x$ \\
POOL & FY F996 Baseline \\
\multicolumn{3}{|c|}{ Full-Time Equivalents (FTEs) } \\
\end{tabular}}} \\
\hline Responsible Analyst & \multicolumn{3}{|c|}{$\begin{array}{l}\text { M.H. Lawrence } \\
\text { FY } 1996 \text { Approved Funding } \\
\text { Full-Time Equivalents (FTEs) }\end{array}$} & \multicolumn{3}{|c|}{$\begin{array}{l}\text { FY1996 Unfunded } \\
\text { Full-Time Equivalents (FTEs) }\end{array}$} & & & \\
\hline TYPE OF FTE & Exempt & Non-Exempt & \begin{tabular}{|l|} 
Bargaining \\
\end{tabular} & Exempt & Non-Exempt & Bargaining & Exempt & Non-Exempt & Bargaining \\
\hline Organizational & & & & 0.0 & & & 0.0 & 0.0 & 0.0 \\
\hline Support & & & & & & & 0.0 & 0.0 & 0.0 \\
\hline TOTAL FTEs & 0.0 & 0.0 & 0.0 & 0.0 & 0.0 & 0.0 & 0.0 & 0.0 & 0.0 \\
\hline COST ELEMENTS & \multicolumn{3}{|c|}{ FY 1996 Approved Funding Budget } & \multicolumn{3}{|c|}{ FY 1996 Unfunded Budget } & \multicolumn{3}{|c|}{ FY 1996 Baseline Budget } \\
\hline . Labor-Regular & & & & 2 & & & & & $\$ 0.0$ \\
\hline . Labor - Overtime & & & & & & & & & 0 \\
\hline 0 Total Labor & & & $\$ 0.0$ & & & $\$ 0.0$ & & & $\$ 0.0$ \\
\hline 1 Materials & 12 & & & & & & 10 & I. & 0.0 \\
\hline 2 Purchased Services & (1) & & & & & & 12 & צl: & 0.0 \\
\hline 3 Other Hanford & m: & & & & & & In: & m & 0.0 \\
\hline 8 Revenue & & & 0.0 & & & & & 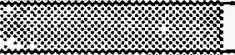 & 0.0 \\
\hline Subtotal Originated Costs: & & & \% $\$ 0.0$ & & & $4 \% \$ 0.0$ & 10 & & 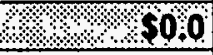 \\
\hline 4 Site Services & & & & & & & (1) & 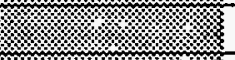 & 0.0 \\
\hline 5 Internal Charges & & & & & & & & ירי & 0.0 \\
\hline 6 IRM Support & & & & rar & & & m & $=$ & 0.0 \\
\hline 7 Overheads & (1) & 2 & & 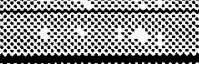 & 1.12 & & 120 & 2 & 0.0 \\
\hline TOTAL DOLLARS & . & 将 & $\$ 0.0$ & 표 & 至 & $\$ 0.0$ & 1 & 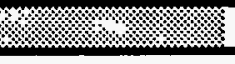 & $\$ 0.0$ \\
\hline $\begin{array}{l}\text { SIGNATURES } \\
\text { Financial Analyst: } \\
\text { CAM: }\end{array}$ & & & $\begin{array}{l}\text { Date: } \\
\text { Date: }\end{array}$ & & BASELINE AP & PRROVAL & & & Date: \\
\hline
\end{tabular}




\begin{tabular}{|c|c|c|c|c|c|c|c|c|c|}
\hline $\begin{array}{l}\text { Work } \\
\text { Breakdown } \\
\text { Structure } \\
\text { Dictionary }\end{array}$ & \multicolumn{6}{|c|}{$\begin{array}{c}\text { Westinghouse Hanford Company } \\
\text { Facilities and Site Services DOH Summary } \\
\text { Part } 1 \text { - Summary } \\
\text { (Dollars in 000's) }\end{array}$} & \multicolumn{3}{|c|}{$\begin{array}{l}\text { FY } 1996 \\
\text { Indirect } \\
\text { Program Plan } \\
\text { Rev. \# } 0 \\
25-\text { Sep-95 }\end{array}$} \\
\hline Cost Account Number & \multicolumn{6}{|c|}{$\begin{array}{l}\text { Cost Account Title } \\
\text { Facilities and Site Services DOH Summary }\end{array}$} & \multicolumn{3}{|c|}{$\begin{array}{l}\begin{array}{l}\text { Proposed Rate: } \\
\text { (Rated Service Pool Only) }\end{array} \\
\end{array}$} \\
\hline $\begin{array}{l}\text { SMS WBS Number } \\
\text { 6.8.6 }\end{array}$ & \multicolumn{6}{|c|}{$\begin{array}{l}\text { SMS Title } \\
\text { Facilities and Site Services }\end{array}$} & \multicolumn{3}{|c|}{ Funding Source: } \\
\hline RL SMS Program Manager & \multicolumn{6}{|c|}{ W.A. Rutherford } & \multicolumn{3}{|l|}{ sws } \\
\hline Cost Account Manager & \multicolumn{6}{|c|}{ M.A. Butterworth, R.M. Tanner } & \multicolumn{3}{|l|}{ OST } \\
\hline WHC SMS Program Manager & \multicolumn{6}{|c|}{ G.A. Harvey } & \multicolumn{3}{|l|}{ DOH } \\
\hline Financial Manager & \multicolumn{6}{|l|}{ M.A. Davis } & \multicolumn{3}{|l|}{ MGT PRO } \\
\hline Responsible Analyst & \multicolumn{3}{|c|}{$\begin{array}{l}\text { M.L.Van Liew } \\
\text { FY 1996 Approved Funding } \\
\text { Full-Time Equivalents (FTES) }\end{array}$} & $\begin{aligned} \text { FY } \\
\text { Full-Ti }\end{aligned}$ & $\begin{array}{l}96 \text { Unfunded } \\
\text { e Equivalents }\end{array}$ & (FTES) & \multicolumn{3}{|c|}{\begin{tabular}{|l|l|} 
POOL & FY 1996 Baseline \\
Full-Time Equivalents (FTEs)
\end{tabular}} \\
\hline TYPE OF FTE & Exempt & Non-Exempt & Bargaining & Exempt & Non-Exempt & Bargaining & Exempt & Non-Exempt & Bargaining \\
\hline Organizational & 28.7 & 7.0 & 12.6 & & & & 28.7 & 7.0 & 12.6 \\
\hline Support & 2.5 & & 1.4 & & & & 2.5 & 0.0 & $\overline{1.4}$ \\
\hline TOTALFTES & 31.2 & 7.0 & 14.0 & 0.0 & 0.0 & 0.0 & 31.2 & 7.0 & 14.0 \\
\hline \multicolumn{10}{|l|}{ COST ELEMENTS } \\
\hline . Labor-Regular & & & $\$ 3,171,8$ & & & & \$י & III & $\$ 3,171,8$ \\
\hline \multicolumn{10}{|l|}{ Labor-Overtime } \\
\hline 0 Total Labor & & & $\$ 3,171,8$ & & & $\$ 0.0$ & & স & $\$ 3,171,8$ \\
\hline 1 Materials & & & 356.4 & & & 0.0 & & (1) & 356.4 \\
\hline 2 Purchased Services & : & & 97.9 & & & 0.0 & & & 97.9 \\
\hline 3 Other Hanford & 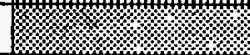 & 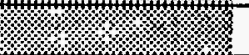 & 13.0 & & & & & W" & 13.0 \\
\hline 8 Revenue & 7 & & 0.0 & & & & & (3) & 0.0 \\
\hline Subtotaloriginated Costs & 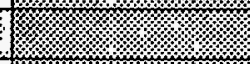 & & $\$ 3,639,4$ & & & $\checkmark \quad 50.0$ & & & $\$ 3 ; 639: 1$ \\
\hline 4 Site Services & 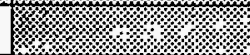 & & $6,003.0$ & & & 0.0 & & (3/: & $6,003.0$ \\
\hline 5 Internal Charges & II & & $1,056.6$ & & & & רי & I: & $1,056.6$ \\
\hline 6 IRM Support & 10 & 1.121-1 & 962.3 & & 4.110 & & 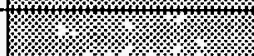 & (19.2? & 962.3 \\
\hline 7 Overheads & 1 & খয & 143.3 & 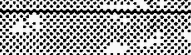 & 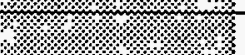 & & יা & יী & 143.3 \\
\hline TOTAL DOLLARS & 1 & 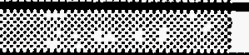 & $\$ 11,804.3$ & 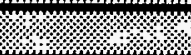 & m. & $\$ 0.0$ & $17=2$ & m. & $\$ 11,804.3$ \\
\hline $\begin{array}{l}\text { SIGNATURES } \\
\text { Financial Analyst: } \\
\text { CAM: }\end{array}$ & & & $\begin{array}{l}\text { Date: } \\
\text { Date: }\end{array}$ & & BASELINE API & PROVAL & & & Date: \\
\hline
\end{tabular}




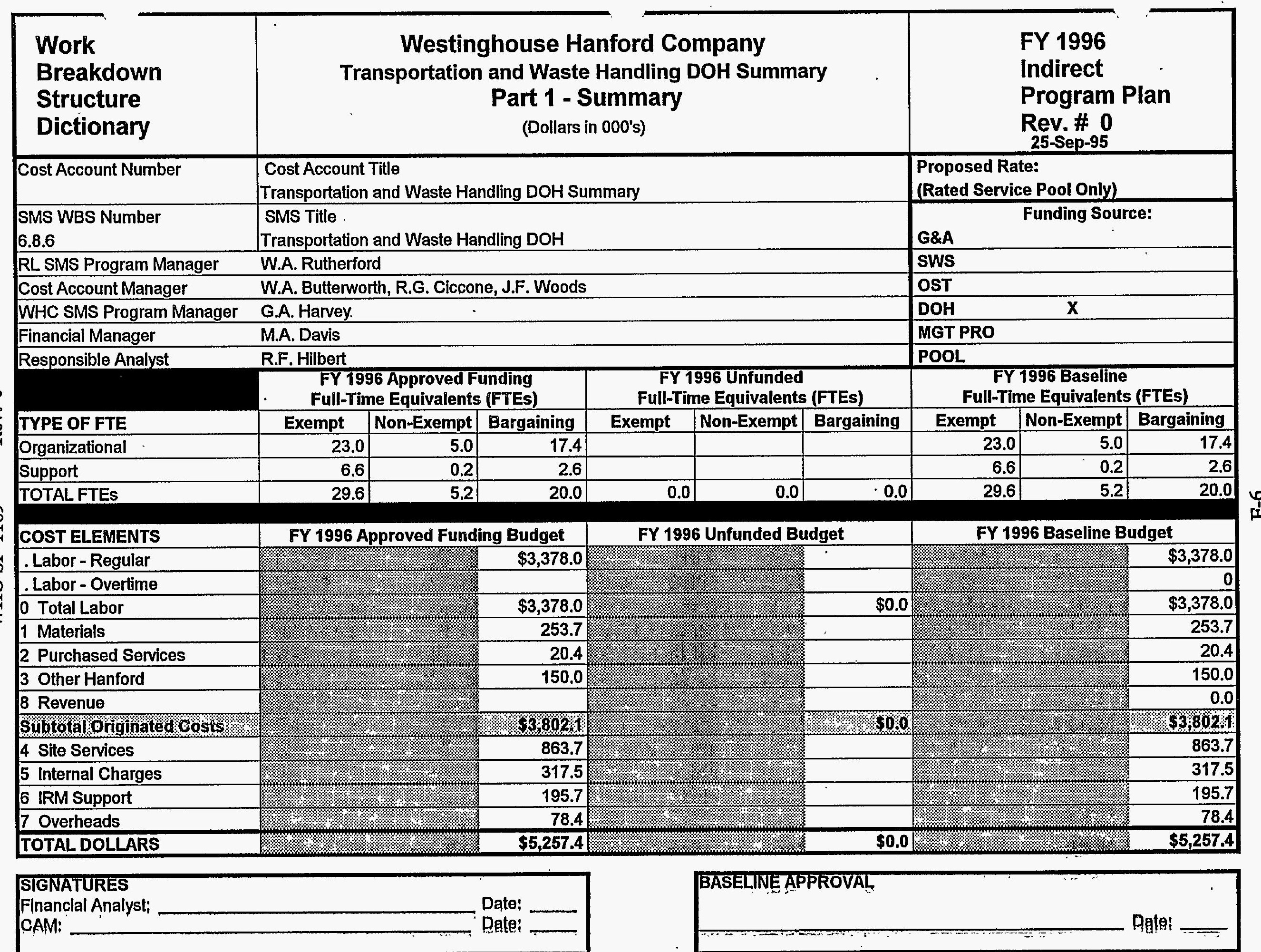




\begin{tabular}{|c|c|c|c|c|c|c|c|c|c|}
\hline $\begin{array}{l}\text { Work } \\
\text { Breakdown } \\
\text { Structure } \\
\text { Dictionary }\end{array}$ & \multicolumn{6}{|c|}{$\begin{array}{c}\text { Westinghouse Hanford Company } \\
\text { Utilities Division Overhead } \\
\text { Part } 1 \text { - Summary } \\
\text { (Dollars in 000's) }\end{array}$} & \multicolumn{3}{|c|}{$\begin{array}{l}\text { FY } 1996 \\
\text { Indirect } \\
\text { Program Plan } \\
\text { Rev. \# } 0 \\
25-\text { Sep-95 }\end{array}$} \\
\hline Cost Account Number & \multicolumn{6}{|c|}{$\begin{array}{l}\text { Cost Account Title } \\
\text { Utilities Division Overhead Summary }\end{array}$} & \multicolumn{3}{|c|}{$\begin{array}{l}\text { Proposed Rate: } \\
\text { (Rated Service Pool Only) }\end{array}$} \\
\hline $\begin{array}{l}\text { SMS WBS Number } \\
6.8 .6\end{array}$ & \multicolumn{6}{|c|}{$\begin{array}{l}\text { SMS Title } \\
\text { Utilities DOH Summary }\end{array}$} & \multicolumn{3}{|c|}{ Funding Source: } \\
\hline RL SMS Program Manager & \multicolumn{6}{|c|}{ W.A. Rutherford } & \multicolumn{3}{|l|}{ SWS } \\
\hline Cost Account Manager & \multicolumn{6}{|l|}{ H.L. Debban } & \multicolumn{3}{|l|}{ OST } \\
\hline WHC SMS Program Manager & \multicolumn{6}{|l|}{ G.A. Harvey } & \multicolumn{3}{|c|}{ DOH $\quad x$} \\
\hline Financial Manager & \multicolumn{6}{|l|}{ M.A. Davis } & \multicolumn{3}{|l|}{ MGT PRO } \\
\hline Responsible Analyst & & \multirow{2}{*}{\multicolumn{3}{|c|}{\begin{tabular}{|l|} 
POOL \\
FY 1996 Baseline \\
Full-Time Equivalents (FTEs) \\
\end{tabular}}} \\
\hline & \multicolumn{3}{|c|}{$\begin{array}{l}\text { FY } 1996 \text { Approved Funding } \\
\text { Full-Time Equivalents (FTEs) }\end{array}$} & \multicolumn{3}{|c|}{$\begin{array}{l}\text { FY } 1996 \text { Unfunded } \\
\text { Full-Time Equivalents (FTEs) }\end{array}$} & & & \\
\hline TYPE OF FTE & Exempt & \begin{tabular}{|l|} 
Non-Exempt \\
\end{tabular} & Bargaining & Exempt & Non-Exempt & Bargaining & Exempt & Non-Exempt & Bargaining \\
\hline Organizational & 4.5 & 1.5 & 0.0 & & 1.0 & & 4.5 & 2.5 & 0.0 \\
\hline Support & 1.5 & & & 0.8 & & & 2.3 & 0.0 & 0.0 \\
\hline TOTAL FTES & 6.0 & 1.5 & 0.0 & 0.8 & 1.0 & 0.0 & 6.8 & 2.5 & 0.0 \\
\hline COST ELEMENTS & \multicolumn{3}{|c|}{ FY 1996 Approved Funding Budget } & \multicolumn{3}{|c|}{ FY 1996 Unfunded Budget } & \multicolumn{3}{|c|}{ FY 1996 Baseline Budget } \\
\hline . Labor - Regular & & & $\$ 474.9$ & & & $\$ 13.8$ & & & $\$ 488.7$ \\
\hline . Labor - Overtime & & & & & & & & & 0 \\
\hline 0 Total Labor & & & $\$ 474.9$ & & & $\$ 13.8$ & & & $\$ 488.7$ \\
\hline 1 Materials & 4 & & 20.0 & & & & & & 20.0 \\
\hline 2 Purchased Senvices & & & 10.0 & & & & & & 10.0 \\
\hline 3 Other Hanford & & & & & & & $\sqrt{3}$ & ". &.$\quad 0.0$ \\
\hline 8 Revenue & & & & & & & & & 0.0 \\
\hline Subtotal originated costs & & & 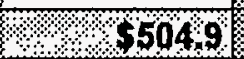 & & & \%॰ 138 & & & +ै\$5187 \\
\hline 4 Site Services & & & 185.7 & & & & & 8 & 185.7 \\
\hline 5 Internal Charges & & 将 & 30.8 & & & & & 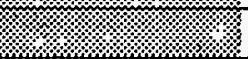 & 30.8 \\
\hline 6 IRM Support & & \% & 42.3 & & & & & "1. & 42.3 \\
\hline 7 Overheads & & 1\%, & & & 槽. & 2.2 & & 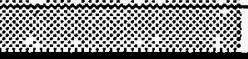 & 2.2 \\
\hline TOTAL DOLLARS & \% & m. & $\$ 763.7$ & \%. & \% & $\$ 16.0$ & X & \% & $\$ 779.7$ \\
\hline $\begin{array}{l}\text { SIGNATURES } \\
\text { Financial Analyst: } \\
\text { CAM: }\end{array}$ & & & $\begin{array}{l}\text { Date: } \\
\text { Date: }\end{array}$ & & BASELINE API & PROVAL & & & Date: \\
\hline
\end{tabular}




\section{Work \\ Breakdown \\ Structure \\ Dictionary}

Cost Account Number

SMS WBS Number

6.8.6

RL SMS Program Manager

Cost Account Manager

WHC SMS Program Manager

Financial Manager

Responsible Analyst

i

COST ELEMENTS

. Labor - Regular

. Labor - Overtime

0 Total Labor

1 Materials

2 Purchased Services

3 Other Hanford

8 Revenue

Subtotal originated Costs

4 Site Services

5 Internal Charges

6 IRM Support

7 Overheads

TOTAL DOLLARS

SIGNATURES

Financial Analyst:

CAM:

Date:

Date:

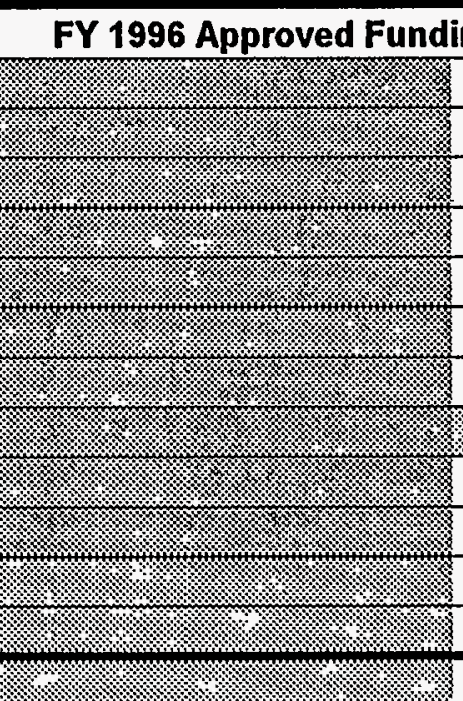

Westinghouse Hanford Company

Infrastructure Programs DOH Summary

Part 1 - Summary

(Dollars in 000's)
FY 1996

Indirect

Program Plan

Rev.\# 0

25-Sep-95

\begin{tabular}{|c|c|c|c|c|c|}
\hline \multicolumn{6}{|c|}{$\begin{array}{l}\text { Cost Account Title } \\
\text { Infrastructure Programs DOH Summary }\end{array}$} \\
\hline \multicolumn{6}{|c|}{$\begin{array}{l}\text { SMS Title } \\
\text { Infrastructure Programs DOH Summary }\end{array}$} \\
\hline \multicolumn{6}{|c|}{ W.A. Rutherford } \\
\hline \multicolumn{6}{|l|}{ G.A. Harvey } \\
\hline \multicolumn{6}{|l|}{ G.A. Harvey } \\
\hline \multicolumn{6}{|l|}{ M.A. Davis } \\
\hline \multicolumn{6}{|l|}{ M.H. Lawrence } \\
\hline \multicolumn{3}{|c|}{$\begin{array}{c}\text { FY } 1996 \text { Approved Funding } \\
\text { Full-Time Equivalents (FTEs) }\end{array}$} & \multicolumn{3}{|c|}{$\begin{array}{l}\text { FY } 1996 \text { Unfunded } \\
\text { Full-Time Equivalents (FTEs) }\end{array}$} \\
\hline Exempt & Non-Exempt & Bargaining & Exempt & Non-Exempt & Bargaining \\
\hline 3.5 & 2.0 & & & . & \\
\hline 2.0 & & & & & \\
\hline 5.5 & 2.0 & 0.0 & 0.0 & 0.0 & 0.0 \\
\hline
\end{tabular}

Proposed Rate:

(Rated Service Pool Only)

G\&A

SWS

OST

DOH

MGT PRO

POOL

ing Budget

\begin{tabular}{r}
$\$ 472.8$ \\
\hline$\$ 472.8$ \\
\hline 1.0 \\
\hline 7.0 \\
\hline \\
\hline 5480.8 \\
\hline 54.0 \\
\hline 11.0 \\
\hline 62.4 \\
\hline 23.6 \\
$\$ 631.8$
\end{tabular}

\begin{tabular}{c} 
FY 1996 Unfunded Budget \\
\hline Und
\end{tabular}

FY 1996 Baseline

Full-Time Equivalents (FTEs)

Exempt Non-Exempt Bargaining

\begin{tabular}{|r|r|r|}
\hline 3.5 & 2.0 & 0.0 \\
\hline 2.0 & 0.0 & 0.0 \\
\hline 5.5 & 2.0 & 0.0 \\
\hline
\end{tabular}

.0

54.0

11.0

23.6

$\$ 631.8$

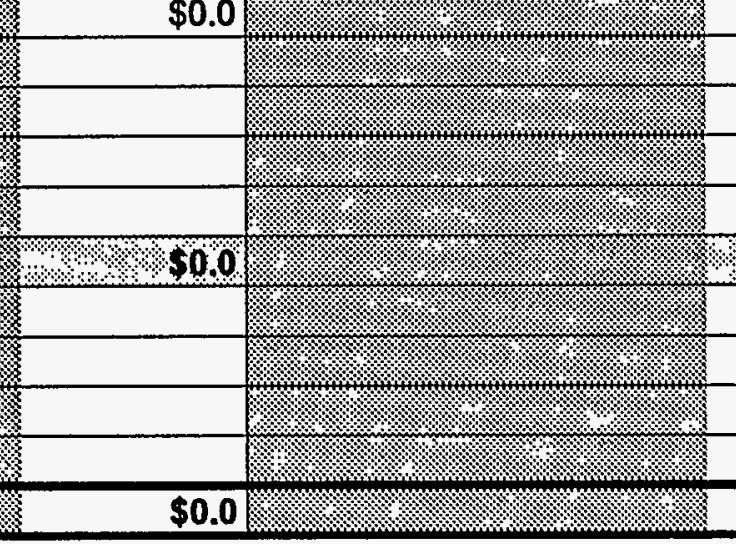

$\$ 0.0$

BASELINE APPROVAL

Tate:

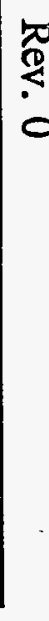


-Table F-7. Milestone Description Sheet.

\begin{tabular}{|c|c|c|c|}
\hline \multicolumn{3}{|c|}{ Title: Complete FY 1997 Site Specific Program Plan (SSPP) } & $\begin{array}{r}\text { Date Prepared: } \\
09 / 26 / 95\end{array}$ \\
\hline \multicolumn{3}{|c|}{ Assigned To: Program Integration } & CIN: \\
\hline \multicolumn{3}{|c|}{ WBS Designator: 6.8 .6} & Due Date: 09/30/96 \\
\hline \multicolumn{3}{|c|}{ Control Number: SSP-96-F02 } & Revịsion: \\
\hline $\begin{array}{l}\text { Milestone Type: } \\
\square \text { DOE-HQ } \\
\text { DOE-RL } \\
\square \text { CNTR } \\
.\end{array}$ & $\begin{array}{l}\text { Division: } \\
\square \text { State } \\
\square \text { Federal } \\
\square \text { DOE } \\
\square \text { RCRA } \\
\square \\
\text { TPA\# }\end{array}$ & $\begin{array}{l}\text { Deliverable: } \\
\square \text { Report } \\
\square \text { Letter } \\
\square \text { Drawings } \\
\text { Other } \\
\text { (specify) SSPP }\end{array}$ & $\begin{array}{l}\text { Address To: } \\
\square \text { DOE-HQ } \\
\square \text { DOE-RL } \\
\square \text { Other } \\
\text { (specify) }\end{array}$ \\
\hline \multicolumn{4}{|c|}{ Milestone Description } \\
\hline \multicolumn{4}{|c|}{ Prepare, coordinate, and issue the Program Integration FY 1996 SSPP. } \\
\hline \multicolumn{4}{|c|}{ Description of what constitutes completion of this milestone: } \\
\hline \multicolumn{4}{|c|}{ Submit SSPP to DOE-RL for review and approval. } \\
\hline \multicolumn{2}{|c|}{$\begin{array}{l}\text { Cost Account Mangagr } \\
\text { A. D. Gadeken (yate }\end{array}$} & \multicolumn{2}{|c|}{$\begin{array}{l}\text { Program/Project Manager } \\
\text { G. A. Harvey }\end{array}$} \\
\hline \multicolumn{2}{|c|}{ 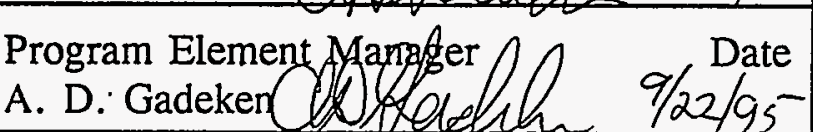 } & \multicolumn{2}{|c|}{$\begin{array}{l}\text { DOE Monitor } \\
\text { W. A. Rutherford } .4 .\end{array}$} \\
\hline
\end{tabular}


Table F-7. Milestone Description Sheet.

\begin{tabular}{|c|c|c|c|}
\hline \multicolumn{3}{|c|}{ Title: Quarterly Performance Measure Reviews } & $\begin{array}{r}\text { Date Prepared: } \\
09 / 26 / 95\end{array}$ \\
\hline \multicolumn{3}{|c|}{ Assigned To: Program Integration } & CIN: \\
\hline \multicolumn{3}{|c|}{ WBS Designator: 6.8 .6} & $\begin{array}{l}\text { Due Date: } \\
\text { Quarterly }\end{array}$ \\
\hline \multicolumn{3}{|c|}{ Control Number: SSP-96-F01 } & Revision: \\
\hline $\begin{array}{l}\text { Milestone Type: } \\
\square \text { DOE-HQ } \\
\square \text { DOE-RL } \\
\square \text { CNTR }\end{array}$ & $\begin{array}{l}\text { Division: } \\
\square \text { State } \\
\square \text { Federal } \\
\mathbf{0} \text { DOE } \\
\square \text { RCRA } \\
\square \\
\text { TPA\# }\end{array}$ & $\begin{array}{l}\text { Deliverable: } \\
\square \text { Report } \\
\square \text { Letter } \\
\square \text { Drawings } \\
\square \text { Other } \\
\text { (specify) } \\
\text { Quarterly Meeting }\end{array}$ & $\begin{array}{l}\text { Address To: } \\
\square \text { DOE-HQ } \\
\square \text { DOE-RL } \\
\square \text { Other } \\
\text { (specify). }\end{array}$ \\
\hline \multicolumn{4}{|c|}{ Milestone Description } \\
\hline \multicolumn{4}{|c|}{$\begin{array}{l}\text { Conduct in-depth quarterly reviews of Infrastructure Program performance measures with } \\
\text { senior RL and contractor management. }\end{array}$} \\
\hline \multicolumn{4}{|c|}{ Description of what constitutes completion of this milestone: } \\
\hline \multicolumn{4}{|c|}{ Meetings held with DOE-RL on a quarterly basis to discuss performance measures. } \\
\hline \multicolumn{2}{|c|}{$\begin{array}{l}\text { Cost Account Manager } \\
\text { A. D. Gadeken Date }\end{array}$} & \multicolumn{2}{|c|}{ 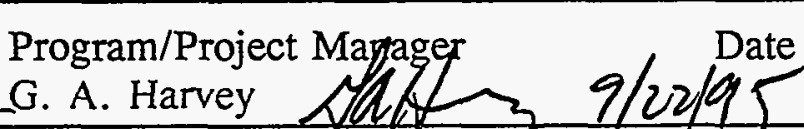 } \\
\hline \multicolumn{2}{|c|}{ 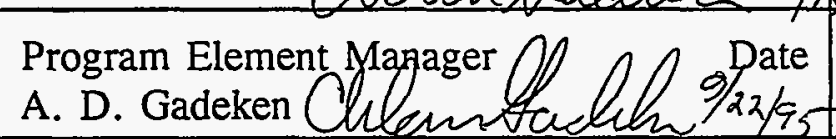 } & \multicolumn{2}{|c|}{$\begin{array}{l}\text { DOE Monitor } \\
\text { W. A. Rutherford }\end{array}$} \\
\hline
\end{tabular}

